UNIVERSIDADE DE SÃO PAULO

FACULDADE DE FILOSOFIA, LETRAS E CIÊNCIAS HuMANAS

DEPARTAMENTO DE GEOGRAFIA

Programa de Pós-GRAduAÇÃo EM GEOGRAFIA Humana

GILMAR DOS SANTOS SOARES

Políticas Públicas e a ReValorizaÇão do esPaÇO No Centro de São Paulo 


\title{
Políticas Públicas e a ReVAlorizaÇão do ESPAÇO NO Centro de São Paulo
}

\author{
Gilmar dos Santos Soares
}

Dissertação apresentada ao Programa de Pós-Graduação em Geografia Humana do Departamento de Geografia da Faculdade de Filosofia, Letras e Ciências Humanas da Universidade de São Paulo, para a obtenção do título de Mestre em Geografia Humana.

Área de concentração: Geografia Humana

Orientadora: Prof. ${ }^{\text {a }}$ Dr. ${ }^{\text {a }}$ Ana Fani Alessandri Carlos 


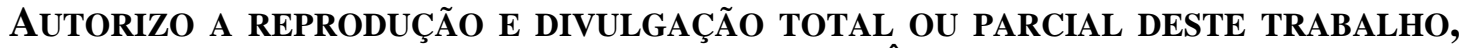
POR QUALQUER MEIO CONVENCIONAL OU ELETRÔNICO, PARA FINS DE ESTUDO E PESQUISA, DESDE QUE CITADA A FONTE.

Catalogação na Publicação Serviço de Biblioteca e Documentação

Versão Corrigida - 2016.

Faculdade de Filosofia, Letras e Ciências Humanas da Universidade de São Paulo

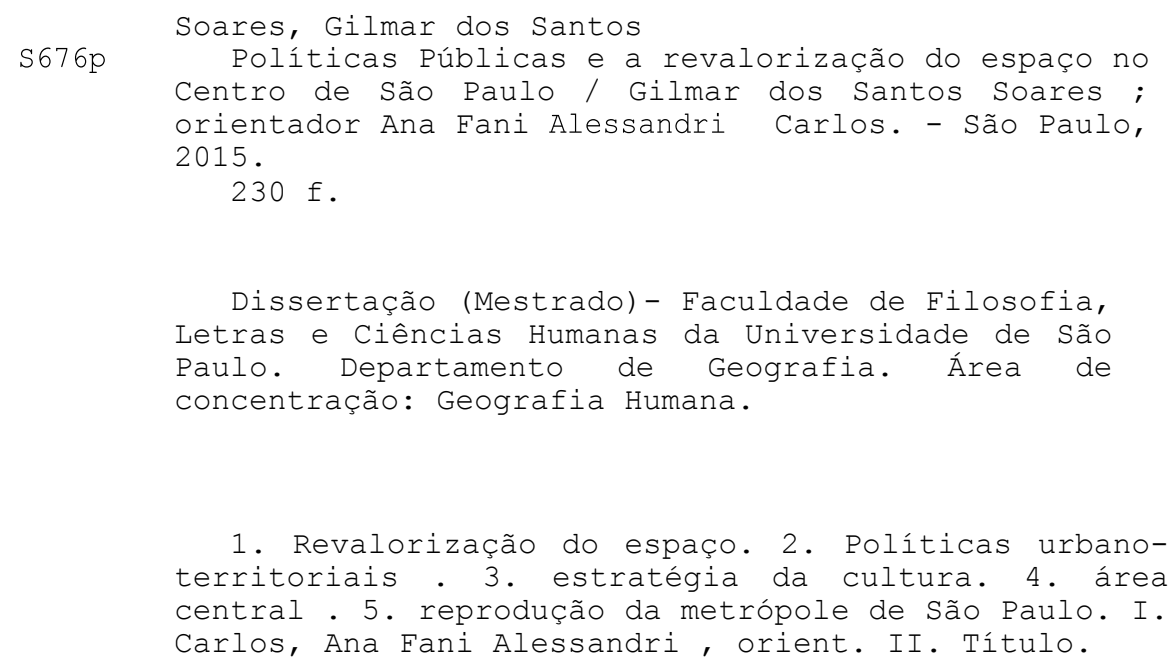

1. Revalorização do espaço. 2. Políticas urbanoterritoriais . 3. estratégia da cultura. 4. área central. 5. reprodução da metrópole de São Paulo. I. Carlos, Ana Fani Alessandri, orient. II. Título. 


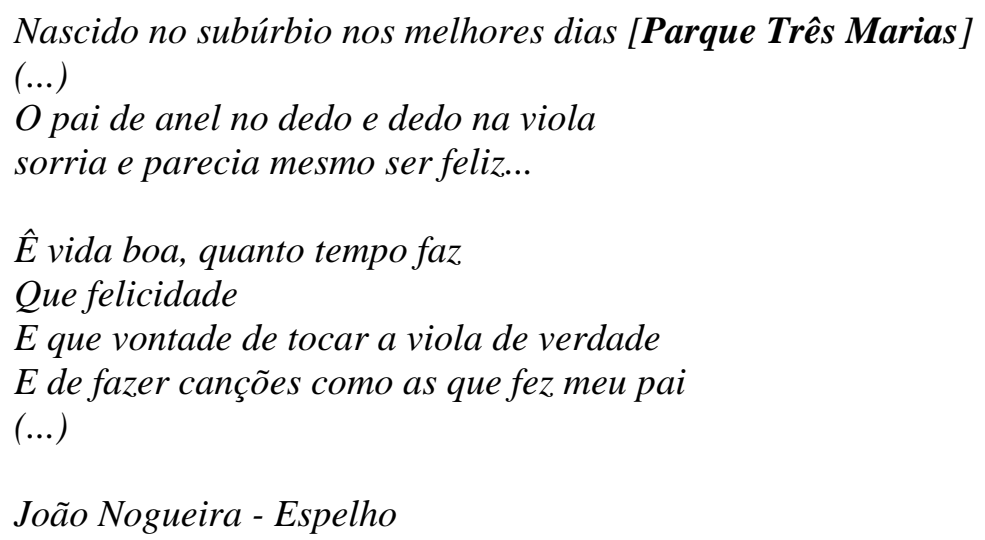

As verdades científicas são sempre paradoxais quando julgadas pela experiência de todos os dias, que somente capta a aparência enganadora das coisas...

Karl Marx 
Dedico este trabalho especialmente a meu pai, Osmar Soares... à sua maneira, ele me ensinou a não ter medo de caminhar sozinho e sem as mãos dadas, para ser firme nas curvas da vida...

Infelizmente ele não pode ver este resultado final, mas me ajudou muito na elaboração. Como soldador e depois como mecânico de refrigeração, ele pode viver durante muito tempo o dia-a-dia da metrópole, conhecendo-a em todos seus cantos, acima e abaixo das ruas...

Saudade é o que fica...

À minha irmã Jane, simplesmente por tudo... Essas linhas, por mais que tenham erros, somente foram escritas graças a você...

Á Kamilla (quem "inventou toda história"), Ana Maria, Denys e aos demais... pela amizade que nasceu das curvas da vida... e pelo gesto de ajuda, humanidade e acolhimento em um momento difícil... 


\section{RESUMO}

Considerando o movimento de explosão da metrópole a partir do processo de industrialização, esta pesquisa buscou compreender o atual processo de revalorização do Centro de São Paulo como um resultado histórico que deriva do processo de reprodução da metrópole. Assim, orientado pela tríade valorização-desvalorização-revalorização, o referencial de análise para o momento atual consistiu no movimento das políticas de intervenção no espaço do Centro de São Paulo, postas em prática pelo Estado a partir da década de 1990. Conforme houve o movimento de explosão da metrópole, houve também a implosão do Centro em função da escassez de espaço que impediu sua adequação às novas necessidades, resultando no desdobramento da centralidade econômica e, por conseguinte, em sua desvalorização. Marcado pela intensificação de um processo de ocupação por classes mais populares, cujo resultado será o das ocupações dos edifícios vazios a partir da década de 1990, a desvalorização será marcada pela deterioração do espaço e por este fator ligado à intensificação da sua ocupação proletária. Neste processo a propriedade privada do solo urbano passa por um processo de apropriação cujo fundamento se realiza em função do uso do espaço. Neste contexto, as políticas para a intervenção no espaço do Centro de São Paulo desenvolvem seus mecanismos para revalorizar o espaço e, ao mesmo tempo, reverter o quadro cada vez maior desta proletarização do Centro. De estratégias pontuais estas passaram para estratégias espaciais, por meio da delimitação estratégica de territórios que visam produzir novas formas de uso para o espaço. Neste movimento, as intervenções para a revalorização do espaço no Centro de São Paulo se realizam enquanto políticas urbanoterritoriais que se articulam e, ao mesmo tempo, são complementadas pelas estratégias da cultura, responsáveis pelas novas representações do espaço. Conforme a metrópole em seu processo de reprodução torna-se força produtiva, o Centro torna-se capital fixo para o processo de reprodução que se realiza por meio da expansão por novas áreas espacialmente contíguas. O resultado é uma disputa pelo espaço conforme o interesse das classes sociais pelo espaço no Centro de São Paulo.

Palavras-chave: revalorização do espaço; políticas urbano-territoriais; estratégia da cultura; área central; reprodução da metrópole de São Paulo. 


\begin{abstract}
Considering the movement of explosion of the metropolis from the industrialization process, this research sought to understand the current of the revaluation process of downtown São Paulo as a historical result that derives from the metropolis reproduction process. Thus, oriented by valuation-devaluation-revaluation triad, the referential of analysis for the current moment consisted in the movement of policy interventions within the São Paulo downtown, implemented by the State from the 1990s. As was the movement of the metropolis explosion, there was also the downtown implosion due to the scarcity of space which prevented their adaptation to new needs, resulting in the deployment of the economic centrality and consequently, in its devaluation. Marked by the intensification of a process of occupation by popular classes, whose result will be the occupations of empty buildings from the 1990s, the devaluation will be marked by the deterioration of space and this factor linked to the intensification of its proletarian occupation. In this process the private ownership of urban land goes through a process of appropriation whose fundament is realized due to the use of space. In this context, policies for intervention in the space of downtown São Paulo develop its mechanisms to revalue the space and at the same time, reverse the situation of this proletarianization of the downtown São Paulo. Of specific strategies these have to spatial strategies, through the strategic demarcation of territories that aim to produce new forms of use for the space. In this movement, interventions to the revaluation of the downtown São Paulo are held as urban-territorial policies that articulate and at the same time, are complemented by strategies of culture, responsible for new representations of space. Therefore, as the metropolis in their reproduction process becomes productive force, the downtown becomes fixed capital for the reproduction process that takes place through the expansion of new spatially contiguous areas. The result is a fight for space as the interest of social classes through space in São Paulo downtown.
\end{abstract}

Keywords: revaluation of space; urban-territorial policies; cultural strategy; central area; reproduction of the metropolis of São Paulo. 


\section{Agradecimentos}

Talvez alguns nomes fiquem de fora, mas, infelizmente, acabei deixando a redação destes agradecimentos para última hora e num momento que a cabeça não anda tão boa.

Pois bem, vamos lá... As mãos ainda continuam pesando...

Agradeço a família de qual faço parte por tudo: as irmãs Jane Fátima, Rosemeire Aparecida e Juceia. Ao meu pai Osmar. Os sobrinhos e sobrinhas Juliana, Lívia, Carlos Eduardo, Larissa, Caroline, Lucas e Luan. A recém-chegada Manoela (sobrinha neta, filha de Juliana). Aos cunhados Luiz Eduardo e Ivair. Ao Lucas, companheiro da Juliana. À Gabi, companheira do Dudu.

Agradeço a Ana Fani pela orientação e oportunidade, neste processo amplo de formação, afinal, eu vim de "fora" e, sem referência alguma, ela aceitou o desafio da orientação. Sou grato por isso.

Agradeço ao professor César Simoni e a professora Cibele Rizek pelas contribuições no exame de qualificação e, posteriormente, na defesa.

Agradeço a CAPES pelo auxílio financeiro que permitiu mergulhar na temática e pesquisar algo que até então não havia pesquisado.

Agradeço ao Coseas, na figura da assistente social Eliane, quem me ajudou com os auxílios para realizar esta pesquisa e o curso de pós-graduação.

Aos trabalhadores e trabalhadoras da Secretaria de Pós-Graduação em Geografia.

Agradeço a duas pessoas de Presidente Prudente que me deram o aval para rodar o mundo e conhecer os caminhos por conta própria... o amigo, orientador e mestre Eliseu e professora Carminha. Muito obrigado de coração. Aproveito a deixa para agradecer a todos os colegas do Gasperr pelas ajudas diretas e indiretas em minha formação, em que faço destaque a Cássio Antunes, Clerisnaldo, Everaldo, Denise entre outros. Agradeço também as pessoas que foram influências em minhas escolhas pelo caminho da Geografia Urbana como a Professora Eda, que me ajudou no início da graduação, e ao Professor e colega Igor Catalão, com que tive a oportunidade de cursar uma disciplina e aprender muita coisa sobre redes urbanas e metrópoles. A amiga (de horas e mais horas de conversa, sobre a vida e a Geografia) nos tempos de projeto temático sobre o Mapa da Indústria, a professora Paula Lindo.

Agradeço ao irmão Felipe César, pela ajuda assim que cheguei a São Paulo.

Agradeço também as professoras e colegas de grupo de pesquisa que contribuíram com o processo de formação e andamento da pesquisa: Isabel, Simoni, Glória, Flor e Jackson do Labur, Lívia Fioravanti, Renan, Luís, Elisa, Fabiano, Genovan, Sávio, Leonardo, Leia entre outros.

Agradeço ao André da SMDU pela conversa sobre vacância no Centro de São Paulo.

Agradeço ao Sídnei e Alexandra da UMM e Luciana do Centro Gaspar Garcia.

"Pros parceiros, tenho a oferecer minha presença, talvez até confusa, mas real e intensa"...

Agradeço sempre aos irmão da rua, da praça e do carrinho.

Aos amigos de sempre: Ervão, Anna Amaro e família, Gustavo "Gordão" e família, Marcus Vinícius “Morcego” e família, Danilo Vianna e família. 
A Ana Cristina e Alanis, pela amizade que perdura há anos. Obrigado pela força sempre.

Agradeço aos irmãos de Prudente: Yuri, Vitor Carioca, Thiago B. F. Vilas Boas, Paulo Maffi, Rodrigo Galão e Leandro Lelê.

Deixo aqui um agradecimento especial (bem como também dedico a ele este texto) ao meu amigo e irmão que a vida me permitiu escolher, Denys. Obrigado por tudo meu camarada. Você é meu amigo, irmão, parceiro de futebol, parceiro das boas conversas, de cervejas, de filosofias e dos bons debates acadêmicos. Mas, mais do que os debates acadêmicos, são melhores nossos debates (a lá mesa redonda) sobre futebol. Sou feliz e grato por ter te conhecido e tenho certeza que nossa amizade é daquelas que perdurará a vida toda. Estas linhas também são pra ti camarada! Você e sua "paciência de Jó" comigo (risos).

Agradeço aos amigos e amigas de São Paulo que a vida cruzou nossos caminhos Jucier, Marcel, Sócrates, Erivaldo, Manoel, Ana Maria, Kamilla, Carlos, Paulo entre outros.

Agradeço Dona Mariazinha (mãe de Denys), Sr. Davys (pai de Denys) e David (irmão de Denys).

Ao amigo Roger Montemor e sua companheira Priscila, seres humanos emancipados e de primeira grandeza.

Um salve para os amigos Samuel, Bigode, Argentino, Piero entre outros.

Agradeço aos amigos do Crusp: Sandro, Daniel, Felipe, Márcio, Anibal, Renato Calabresa, Elias.

Aos amigos do alojamento: Michel, Eder, Lucas e Tomé Bambo.

Deixo um agradecimento especial a duas amigas: Karime Fante (obrigado pela amizade branquela) e Aline Novais, intensa, firme, de força e canceriana ao mesmo tempo.

Aos maravilhosos: Fábio, Willian e Joviniano Netto, amo demais vocês meninos!

As amigas: Rafaela, Patrícia, Sandra (e seu companheiro Ronaldo).

Aos amigos das disciplinas: João, Fernanda, Diegão, Rodrigo, Claudio entre outros.

Aos funcionários da Coseas: Marquinhos, Barbosa, Paraná, Tonhão, Léo, Márcio, Joice, Lia entre outros.

Aos trabalhadores e trabalhadoras da Uspão: Jucélio e seu irmão, Lucas, Celise, Curintia, Nenê Palmeirense, Seu Augusto, Rosy, Samuel entre outros.

Aos companheiros da LS/Unidos: Manuel, Nanci, Suzete, Cabral, Alex, Alexandre, Alexandro, Flávio, Maurício, Jaqueline entre outros.

Por fim quero registrar dois agradecimentos especiais.

A minha irmã Jane que me ajuda com tudo e em tudo.

A minha mãe, Benedita Maria, que sempre me incentivou a encarar o mundo com um sorriso no rosto. Cuida bem do velho aí. O amor fica. Ainda nos veremos. "Bença".

A todos, muito obrigado!

Desculpa as pessoas que acabei me esquecendo de agradecer nestas linhas... 


\section{LISTA DE FigURAS}

Figura 1 - À esquerda, Distrito Sé (Centro "Velho") e Distrito República (Centro "Novo").

Década de 1960 16

Figura 2 - Distritos do Centro Tradicional (Sé e República) e faixa de distritos que compõem o "vetor sudoeste" 22

Figura 3 - Ocupações realizadas entre 1997 e 2005 ---------------------------------- 29

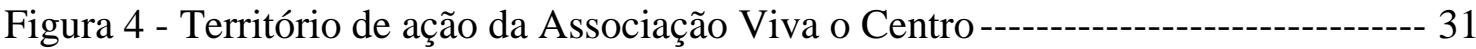

Figura 5 - Operação Urbana Centro e distritos do entorno -------------------------------- 85

Figura 6 - Ocupação Ipiranga e Edifício Retrofit Vanguard Ipiranga--------------------- 91

Figura 7 - Espacialização das Intervenções Urbanísticas do PROCENTRO/BID------ 118

Figura 8 - Âncoras e Conexões do Projeto "Nova Luz" ----------------------------------- 124

Figura 9 - Território do "Arco do Tietê" e a fração dos distritos Bom Retiro, Pari e Brás134

Figura 10 - Pontos de Centralidade do "Arco do Futuro" --------------------------- 139

Figura 11 - Setores de Intervenção: PPP Casa Paulista - Área Central ------------------ 145

\section{LiSTA DE MAPAS}

Mapa 1 - Distritos Sé e República e distritos do entorno

Mapa 2- Território da Concessão Urbanística Projeto "Nova Luz" ............................ 121

Mapa 3 - Macroárea de Estruturação Metropolitana e Operação Urbana Centro ......... 135

Mapa 4 - Território e zonas de paisagem e preservação cultural ................................ 157 


\section{LISTA DE QUADROS}

Quadro 1 - Operação Urbana Centro: propostas com venda de potencial construtivo-- 95 Quadro 2 - Operação Urbana Centro: propostas com solicitações de exceções à Lei de Parcelamento, Uso e Ocupação do Solo 100

Quadro 3 - Relação entre a Operação Urbana Centro, o Setor Central e a Macroárea de

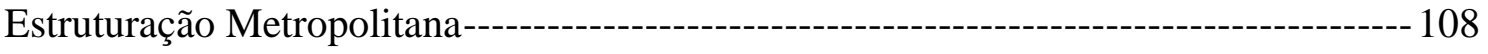

Quadro 4 - Territórios de intervenção da Parceria Público-Privada---------------------- 144

Quadro 5 - Distribuição de moradias por faixa de renda salarial ------------------------- 148

Quadro 6 - Políticas predominantemente pontuais de reformas de equipamentos culturais $-154$

\section{LISTA DE TABELAS}

Tabela 1 - População nos anos de levantamento censitário, 1872 e 1970. Município de São Paulo, Região Metropolitana de São Paulo e Estado de São Paulo --------------------- 14 Tabela 2 - Variação da Taxa de Vacância nos Distritos do Centro de São Paulo entre os

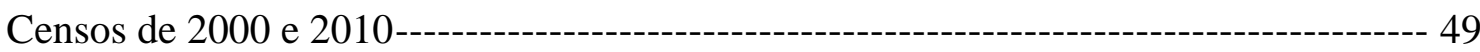

Tabela 3 - Estoques disponibilizados nos distritos da área central ---------------------- 104

Tabela 4 - BID: recursos empregados no PROCENTRO -------------------------------- 116

Tabela 5 - Intervenções Urbanísticas do PROCENTRO ------------------------------117 


\section{LISTA DE SigLAS}

AR-SÉ - Administração Regional Sé

AVC - Associação Viva o Centro

BANCOOP - Cooperativa habitacional dos bancários

BID - Banco Interamericano de Desenvolvimento

CAE - Comissão de Assuntos Econômicos do Senado

CEPAC - Certificado de Potencial de Adicional Construtivo

CLTU - Câmara Técnica de Legislação Urbanística

CNLU - Câmara Normatiza de Legislação Urbanística

COE - Código de Obras e Edificações

COHAB-SP - Companhia Metropolitana de Habitação de São Paulo

CPP - Companhia Paulista de Parcerias

EIA-RIMA - Estudos de Impactos Ambientais - Relatório de Impactos no Meio Ambiente

FC - Fórum dos Cortiços e Sem Teto de São Paulo

FCV - Fórum Centro Vivo

FIPE - Fundação Instituto de Pesquisas Econômicas7

HIS - Habitação de Interesse Social

HMP - Habitação de Mercado Popular

IBGE - Instituto Brasileiro de Geografia e Estatística

IPTU - Imposto Predial Territorial Urbano

LOM - Lei Orgânica do Município

LPUOS - Lei de Parcelamento, Uso e Ocupação do Solo

MMC - Movimento de Moradia do Centro

MPF - Ministério Público Federal

MSP - Município de São Paulo

MSTC - Movimento dos Sem Teto do Centro

MUC - Movimento Unificado Dos Cortiços

OU Interligadas - Operação Urbana Interligadas

OUAB - Operação Urbana Água Branca

OUAE - Operação Urbana Água Espraiada

OUC - Operação Urbana Centro

OUFL - Operação Urbana Faria Lima

OUVA - Operação Urbana Vale do Anhangabaú

PDE - Plano Diretor Estratégico

PGV - Planta Genérica de Valores

PMI - Procedimento de Manifestação de Interesses

PMSP - Prefeitura Municipal de São Paulo

PPP - Parceria Público-Privada

PRE - Plano Regional Estratégico

PUE - Projeto Urbanístico Estratégico

SEMPLA - Secretaria Municipal de Planejamento

SMC - Secretaria Municipal de Cultura

SP-URBANISMO - São Paulo Urbanismo

TICP - Território de interesse da cultura e da paisagem

TJSP - Tribunal de Justiça de São Paulo

VGV - Valor Geral das Vendas

ZEPEC - APC - Zonas Especiais de Preservação Cultural - Área de Proteção Cultural

ZEPEC-BIR - Zonas Especiais de Preservação Cultural - Bens de Imóveis Representativos 
Apresentação ......................................................................................................................XIV

Introdução …...................................................................................................................................... 1

\section{Capítulo I}

Valorização-desvalorização-revalorização do Centro de São Paulo.

1.1. A explosão da cidade induzida pela industrialização: a implosão do Centro e a sua centralidade em São Paulo

1.2. Do industrial ao financeiro (e/ou terciário avançado): as metamorfoses do Centro no espaço-tempo da metrópole................................................................................................ 20

1.3. Desvalorização e revalorização do Centro: a escassez do espaço e as lutas de classes como lutas pelo Centro de São Paulo.

\section{Capítulo II}

$O$ centro da metrópole sob o crivo da propriedade privada do solo urbano

2.1. O fundamento da propriedade privada do solo no movimento de revalorização do Centro

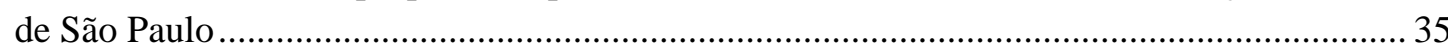

2.2. O fenômeno da vacância imobiliária no Centro de São Paulo ........................................... 37

2.3. A reversão do "impasse" da propriedade privada do solo no Centro de São Paulo .......... 51

\section{Capítulo III}

As estratégias do Estado para a revalorização do Centro de São Paulo .................. 66

3.1. As políticas urbano-territoriais no movimento da reprodução do Centro de São Paulo .. 68

3.1.1. As políticas urbano-territoriais e a mundialização do espaço

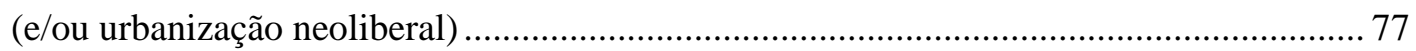

3.1.2. A reversão das conquistas de classe na cidade ........................................................ 79

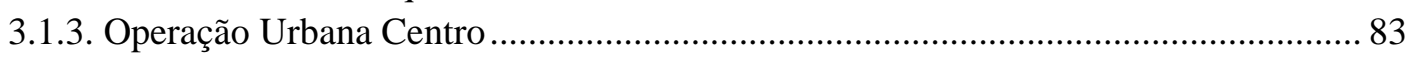

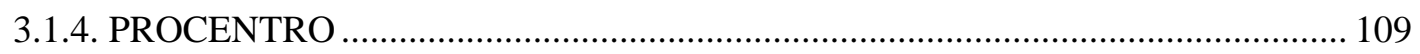

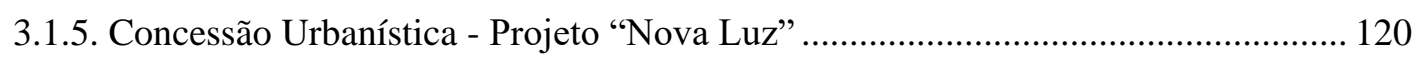

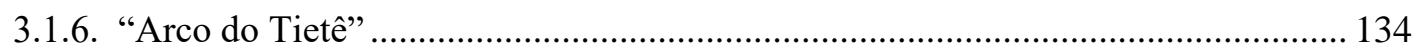

3.1.7. PPP Casa Paulista - Habitação na Área Central da cidade de São Paulo ................. 141

3.2. A cultura como estratégia política para a revalorização estética do Centro de

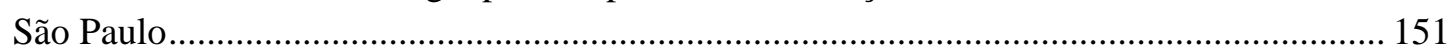

3.2.1. Estratégia da cultura, economia criativa e prática econômica do turismo: a estética

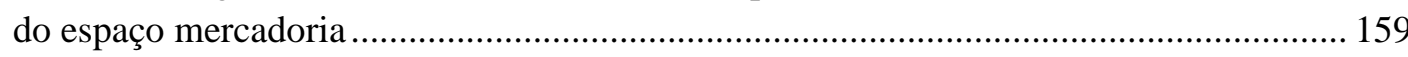

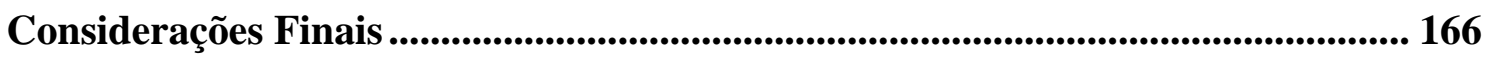

Bibliografia............................................................................................................................. 177

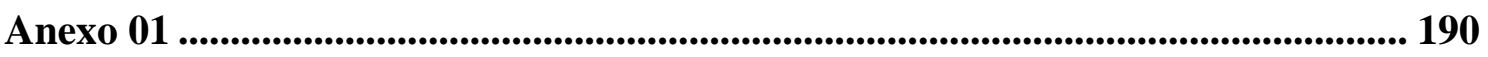

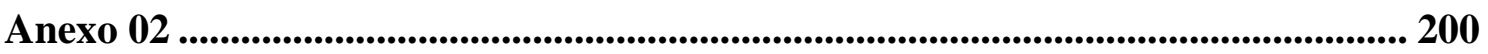

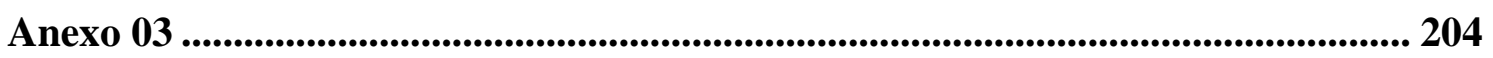




\section{APRESENTAÇÃo}

Esta dissertação consiste numa leitura crítica das políticas do Estado direcionadas para a revalorização do Centro de São Paulo, realizadas, principalmente, após a década de 1990. A análise e interpretação dessas políticas de intervenção no espaço são consideradas a partir de um ponto de vista que as consideram como um instrumento político, atravessadas e caracterizadas por uma racionalidade instrumental que homogeneiza, fragmenta e, ao mesmo tempo, hierarquiza o espaço conforme ocorre o processo de urbanização na atualidade. As políticas do Estado, que se realizam por meio da delimitação estratégica de territórios de intervenção voltadas para o Centro de São Paulo e seu entorno, se revelam também como um dos principais aspectos que fomentam e compõem o conjunto das intervenções que ocorrem no âmbito da reprodução da metrópole. Conforme foram sendo realizadas e postas em prática, tanto nos distritos Sé e República quanto nos distritos que compõem o entorno, estas políticas do Estado delimitam territórios estratégicos capazes de orientar os investimentos imobiliários em alguns desses distritos.

Nestes termos, o sentido das intervenções do Estado nestes distritos que compõem a área central da metrópole de São Paulo revela uma dimensão da produção política e instrumental do espaço que mobiliza o nível político com o econômico, para fim de pôr em curso as estratégias que fomentam neste espaço a produção de um novo valor de uso que, ao realizar o processo de troca atribuído de um valor, irá ser posto à venda. Entretanto, em função do próprio movimento de desvalorização, o Centro de São Paulo passou por um significativo processo de ocupação de uma parcela mais pobre da sociedade que somou-se ao contingente pobre que já vivia no Centro de São Paulo, principalmente nos bairros e/ou lugares onde já havia o predomínio de cortiços.

Em São Paulo, atualmente, o fenômeno urbano se realiza através de contradições que lhes são internas, decorrentes do próprio mecanismo de reprodução da metrópole e que adquire os conteúdos de uma mundialidade, contudo, que abrange também as dimensões que são intrínsecas às relações cotidianas da vida prática em que se constituem as formas de resistência. Ao mesmo tempo, este processo de reprodução marcado pelas contradições revela também os conflitos que decorrem dos interesses das classes sociais pelo espaço. No caso do Centro de São Paulo - que no período atual encontra-se com um contingente mais significativo de ocupação proletária - a disputa pelo espaço envolve, de um lado, a necessidade para a manutenção e realização da vida de quem sobrevive às duras penas do cotidiano e, do outro, a perspectiva de que o espaço do Centro de São Paulo surge como 
possibilidade para a realização da acumulação (seja na atualidade ou no devir). Assim, as questões que atravessam o processo de revalorização do Centro de São Paulo devem ser compreendidas a partir de um duplo movimento do pensamento, sendo que, primeiramente, um movimento de regressão deve ser feito para fins de localizar no tempo as continuidades e descontinuidades inerentes à problemática atual; posteriormente, outro movimento, o de progressão, portanto, do passado (analisado também em função das suas descontinuidades) para o presente, o tempo atual. Duas frentes tornam-se referências para a realização deste movimento: 1) as políticas urbano-territoriais para a revalorização do Centro de São Paulo; e 2) a transição da década de 1980 para a década de 1990, com o início e predomínio destas políticas em um contexto neoliberal.

A produção do espaço, enquanto perspectiva de análise, nos lança, por um lado, para uma análise da metrópole estendida (explodida em sua extensão e ao mesmo tempo implodida, concentrada e acentuada pelos conteúdos do urbano) e, por outro, do cotidiano, ligado às formas de consumo decorrente deste tipo específico de produção.

No que tange à perspectiva da cidade em sua extensão, uma contradição do espaço ilumina a perspectiva da pesquisa, quando considerada em paralelo com o movimento regressivo-progressivo da análise. A contradição entre abundância e raridade é posta em função do próprio Centro de São Paulo que foi implodido (concentrado e acentuado) pelos conteúdos do processo de urbanização na metrópole, tem no fenômeno da raridade sua chave de interpretação para a problemática que assegura esta pesquisa. Ao mesmo tempo, o mesmo movimento do método regressivo-progressivo permite ponderar na descontinuidade espaçotemporal um processo que assegura a continuidade da reprodução, por meio de um movimento de valorização-desvalorização-revalorização do Centro de São Paulo. A tríade guarda em si uma relação espaço-temporal, cujo movimento vai do espaço da produção à produção do espaço, sendo que neste último é a reprodução capitalista da metrópole quem dita o ritmo do processo de revalorização em função da valorização diferenciada dos seus lugares ${ }^{1}$. Dessa maneira, a problemática inerente ao Centro de São Paulo é também uma problemática do espaço, afinal, foi somente com o avanço das forças produtivas que o espaço tornou-se também uma força produtiva.

À luz da valorização diferenciada dos lugares da metrópole, o Centro é portador de características que o metamorfoseia em condição e meio da reprodução, afinal, enquanto "polo acumulador de conteúdos da urbanização" este fragmento da metrópole torna-se

\footnotetext{
${ }^{1} \mathrm{O}$ que nos remete de imediato ao movimento que vai do espaço da produção, à produção do espaço e, por fim, à reprodução do espaço.
} 
também um instrumento de produção, seja por meio de estratégias políticas diretamente vinculadas ao Estado, ou, seja através das estratégias do capital ligadas às possibilidades de acumulação através da produção e consumo do próprio Centro, levando em conta seus próprios conteúdos atuais, historicamente e socialmente produzidos.

Há também, por outro lado, uma dinâmica das lutas de classes na disputa pelo Centro de São Paulo, reveladora de uma Geografia em que o espaço (histórico e ao mesmo tempo social) torna-se condição, meio e produto da reprodução social. A reprodução do Centro de São Paulo, por sua vez, revela, por meio de um processo de revalorização, o imperativo de realização do capital e, neste movimento, o fundamento do valor de troca que se realiza a partir da produção de um novo valor de uso para o espaço. O ciclo se realiza quando este novo espaço com novas características (portanto, reproduzido) é posto novamente em circulação (sob os pressupostos e conteúdos deste novo valor de uso) e distribuído para aqueles que podem pagar pela parcela deste espaço produzido e pronto para o consumo. Convém salientar que o processo de revalorização se realiza através de uma dinâmica específica, conforme há a inserção da indústria do imobiliário no Centro de São Paulo, e esta, por sua vez, passa a ser determinada por outros fatores ligados às estratégias de mercado.

No movimento da reprodução social balizada pelo fundamento do valor de troca, há também de se considerar o espaço enquanto forma-mercadoria, como aquilo que se torna objeto de extensão desta forma. Assim, a reprodução social se alinha àquilo que caracteriza e produz o espaço mercadoria, compondo o conjunto das relações de compra e venda, que deriva das relações de produção e consumo do espaço, cujo resultado somente pôde desencadear em um processo específico de segregação socioespacial. Enquanto a reprodução social revela o fundamento da forma-mercadoria, que delimita as formas de acesso à cidade e à vida urbana, a reprodução do próprio espaço revela também uma dimensão política centralizada no Estado, em função do poder de dominar, hierarquizar e homogeneizar as relações no espaço; consequentemente essa dimensão política também assegura sua continuidade por meio do processo que é próprio a reprodução da metrópole.

A produção política do espaço revela o nível em que o Estado ganha significado preponderante no processo de acumulação através da reprodução capitalista da metrópole. Neste nível as estratégias se acumulam, se sobrepõem, se superpõem, se realizam em paralelo e revelam as formas como o Estado assegura as condições para que os investimentos privados sejam feitos no espaço. Assim, o Estado homogeneíza, quebra e, ao mesmo tempo, hierarquiza os espaços, dominando-os e coordenando-os, revelando um caráter regulador do espaço político. A racionalidade instrumental posta em prática pelo Estado revela o espaço 
enquanto um meio de produção, cuja possibilidade maior ou menor de acumulação ocorre conforme a valorização diferenciada dos lugares e metamorfoseia a metrópole em força produtiva. A produção política do espaço também revela que os mecanismos de objetivação das relações capitalistas são externas ao próprio Estado, contudo, este assegura a reprodução do capital através de vários mecanismos que são políticos, porém, entre eles, fazemos um destaque à produção do espaço

A relação entre Estado, espaço e capital imputa ao processo de revalorização do Centro de São Paulo - compreendido enquanto um processo marcado por continuidades e descontinuidades - uma problemática específica que moveu esta pesquisa. No movimento de reversão do processo de desvalorização do Centro de São Paulo, tanto as políticas urbanoterritoriais quanto outras estratégias do Estado coadunam com as estratégias e interesses do capital para a revalorização deste fragmento da metrópole. No Centro (Distritos Sé e República) e seu entorno imediato, as possibilidades de continuidade do processo de acumulação tendem a se realizar (e/ou já se realizam) através da reprodução do seu espaço. $\mathrm{O}$ movimento que vai da desvalorização para a revalorização expressa em seus conteúdos uma Geografia das lutas de classes, específica ao Centro de São Paulo enquanto um espaço em disputa, já que, desde meados da década de 1980, o processo de ocupação proletária deste fragmento da metrópole vem se intensificando.

$\mathrm{Na}$ atualidade as políticas espaciais do Estado voltadas para a revalorização do Centro de São Paulo revelam a sinergia destas com os interesses do capital, no momento em que sua reprodução se realiza através da reprodução da metrópole. Neste sentido, a metrópole se redefine também enquanto força produtiva $^{2}$ e indutora do processo de sua urbanização na atualidade. Assim sendo, a problemática inerente ao Centro de São Paulo têm no espaço e nas políticas do espaço (através de relações e mecanismos de operação destas políticas) os próprios conteúdos classistas da reprodução social - o que antes ficava a cargo apenas das relações de produção que se realizavam no "chão da fábrica".

A revalorização do Centro de São Paulo - enquanto um processo em que os lugares se metamorfoseiam em capital fixo - é apenas uma dimensão complexa do mosaico diversificado que caracteriza a totalidade da reprodução da metrópole 3 . Aos "olhos do capital", o Centro de São Paulo torna-se o espaço das possibilidades de acumulação futura,

\footnotetext{
2 Já que em sua realidade urbana, ainda mais no Centro onde o espaço torna-se raro, os lugares se metamorfoseiam em capital fixo, ao mesmo tempo em que transformam significativamente as relações de produção.

${ }^{3}$ Lefebvre (1973, p. 110) concebe a reprodução das relações sociais de forma mais ampla, levando em consideração a vida cotidiana, a cidade e o urbano. Segundo o autor, é onde se reproduz e se realiza também o mais-valor global da sociedade, seja na arte, na cultura, na ciência e em muitos outros setores.
} 
contudo, que se realiza desde já como o ir-sendo de uma nova fronteira urbana de acumulação, ao mesmo tempo em que o processo de sua reprodução revela os traços de barbárie do processo capitalista de urbanização na virada do século XX para o século XXI.

Se o processo de urbanização de São Paulo ao longo do século XX produziu a explosão, esta veio acompanhada do processo de valorização do Centro de São Paulo; já sua desvalorização pode ser compreendida em função do processo de sua implosão (conforme houve também a explosão) e o momento em que as contradições do espaço surgiram e redefiniram o processo de reprodução da metrópole. Com o Centro implodido e impedido de expansão, houve o movimento de transbordamento da centralidade econômica para outros subcentros que se localizam no vetor sudoeste da metrópole. Este movimento da centralidade econômica para os lugares que habitavam a burguesia e a pequeno-burguesia paulistana, fez com que o Centro de São Paulo (apesar de portador de centralidade metropolitana) fosse, cada vez mais, ocupado por uma parcela proletária da população. Nestes termos, o Centro é um fragmento da metrópole que é portador de uma centralidade que contém uma diversidade de equipamentos de infraestrutura - principalmente as de transporte - cuja reprodução se explicita pelo processo de reprodução capitalista da metrópole.

Atualmente, o processo de reprodução do Centro de São Paulo é também seu processo de revalorização, através de políticas que são definidas como revitalização, requalificação, reabilitação etc. O processo de reprodução do Centro de São Paulo, enquanto processo que se realiza através das estratégias de revalorização, faz também parte de uma totalidade maior, compreendido a partir do processo de reprodução capitalista diferenciado da metrópole.

O plano de exposição desta dissertação consiste em três capítulos e uma introdução. O primeiro capítulo expõe os conteúdos históricos que permitam localizar o leitor nas continuidades e descontinuidades que se realizam tanto no espaço quanto no tempo do Centro de São Paulo. Dessa maneira, são apontados os momentos de valorização e desvalorização do Centro de São Paulo. Assim posto, consideramos também que a atualidade da revalorização é um processo que somente se realiza em paralelo ao processo de deterioração do espaço. Este movimento compõe os conteúdos de boa parte da introdução que objetiva lançar o leitor no debate a partir dessa relação ${ }^{4}$ inerente à reprodução imediata do real. No segundo capítulo, há um esforço de expor como que, neste movimento de reprodução do Centro, a propriedade privada do solo (foi e) é a forma que ganha importância para compreender os conflitos que se realizam enquanto disputa pelo espaço. A propriedade privada do solo urbano, enquanto

\footnotetext{
${ }^{4}$ Valorização-desvalorização-revalorização.
} 
forma que permite a realização da vida e o uso do lugar, se tornou uma espécie de "impasse" para o capital. Posto o "impasse", a única resolução (e que não pode ser em curto prazo) somente se realiza por meio do Estado através de mecanismos específicos. O terceiro capítulo compreende em explicitar estes mecanismos realizados pelo Estado, que possibilitam liberar espaços como também revalorizar o Centro de São Paulo. Nesse caso, destacamos tanto as políticas urbano-territoriais quanto as estratégias que giram em torno de fomentar condições que afirme o Centro de São Paulo através da representação da cultura. E, por fim, o as considerações finais, em que a exposição tem como referencial os conteúdos que derivam desta realidade em que o Estado, através do conjunto de estratégias compreendidas no âmbito da dominação, torna-se um dos principais componentes para compreender esta dinâmica. Por este viés, o sentido atribuído ao período atual, em que há a ocorrência dessas políticas, caracteriza-se no fundamento crítico das mesmas, pois, enquanto medidas desenvolvidas pelo Estado para a condução do processo de urbanização, elas também revelam os conteúdos da problemática urbana por meio da busca de soluções inerente às modalidades da reprodução da metrópole que são características à sociedade urbana, principalmente nos momentos de crise em que novas atividades devem assegurar as taxas de acumulação de forma generalizada. 


\section{INTRODUÇÃOO}

O estudo das políticas de intervenção no espaço que estão postas para o Centro de São Paulo tem como objetivo compreender por quais mecanismos o Estado, através de suas intervenções, visa reverter à contradição entre raridade e abundância do espaço, a fim de reverter também sua desvalorização. A produção política e instrumental do espaço, por parte das ações do Estado, centraliza o empreendimento para a produção também dos conteúdos que objetivam atrelar ao espaço às novas representações, de maneira com que estas possam ser apropriadas para a configuração de um novo valor de uso e, consequentemente, se realizarem como valor de troca. A redefinição destas representações do espaço também se realiza na redefinição dos conteúdos e das estratégias que estão para os distritos Sé e República, bem como seu próprio entorno que lança para estes bairros predominantemente populares as tensões entre as classes em função da diversidade de interesses pelo espaço. A pesquisa se concentrou nos distritos Sé e República e nos distritos que compõem seu entorno imediato, caracterizados pela contiguidade espacial dessas zonas limítrofes: Santa Cecília, Bom Retiro, Pari, Brás, Cambuci, Liberdade, Bela Vista e Consolação, conforme o mapa a seguir.

Mapa 1 - Distritos Sé e República e distritos do entorno

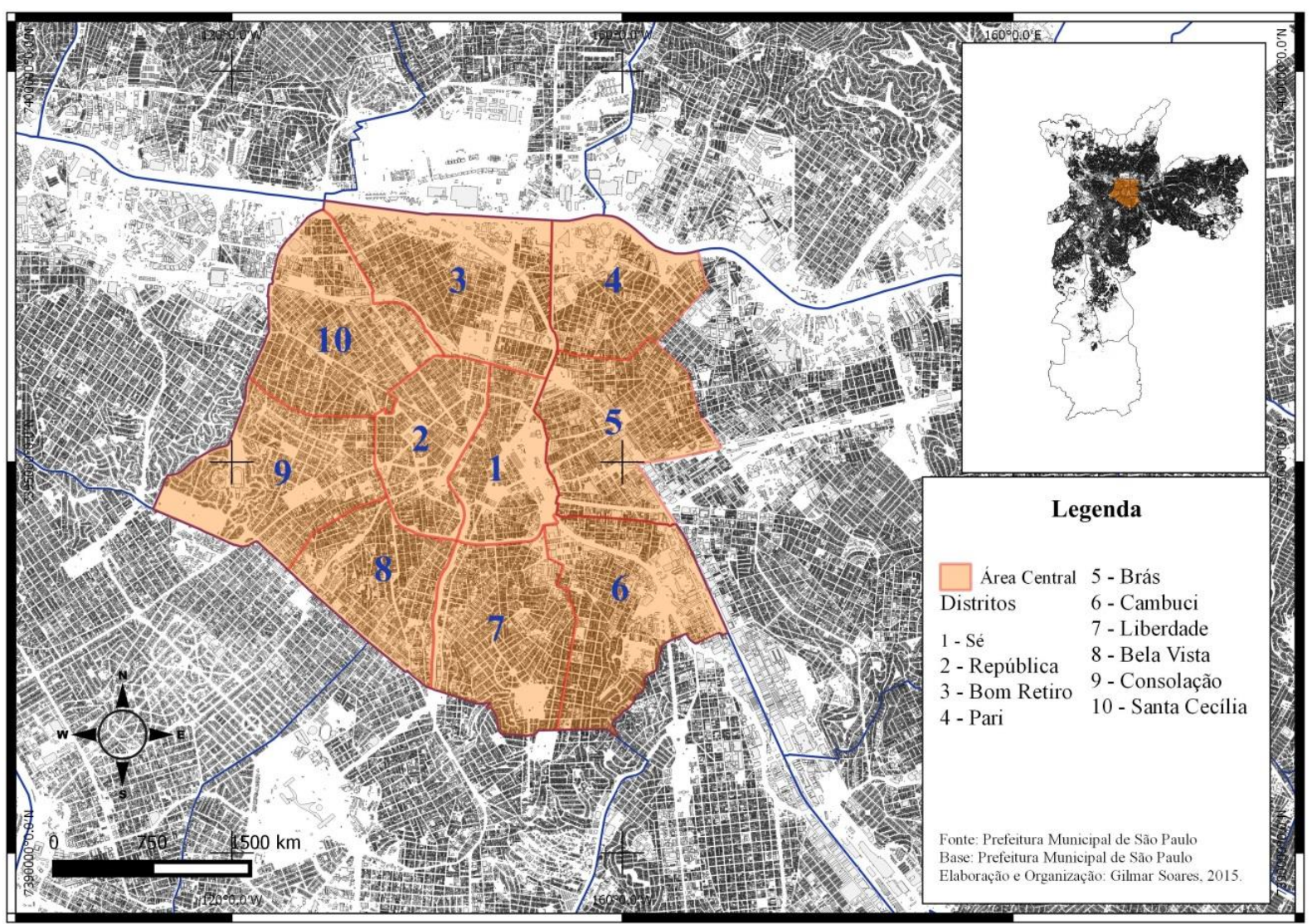


Tanto nos distritos Sé e República quanto nos distritos que compõem seu entorno imediato (caracterizados pela contiguidade espacial dessas zonas limítrofes) as estratégias políticas desenvolvidas e postas em prática pelo Estado caracterizam um novo momento do processo de urbanização marcado pelas estratégias que produzem uma sinergia entre capital e poder público. Assim, as ações do Estado tornam-se um complemento às ações do capital e se realizam por meio da reprodução do espaço.

No caso deste estudo das políticas para a revalorização do Centro de São Paulo, a noção de reprodução amplia o foco da análise e permite localizar no âmbito de uma disputa classista a centralidade do Estado em meio a este processo. Ao superar a noção de produção a reprodução permite-nos localizar, para além da dimensão econômica, a dimensão política e social das relações que ocorrem no espaço. Levando em conta essa ampliação de níveis de análise, tanto as relações de exploração quanto às relações de dominação tornam-se os elementos que atravessam a luta pelo Centro de São Paulo enquanto uma dimensão das lutas de classes. A relação entre Estado e capital adquire novos significados no interior do fenômeno urbano, revelando os traços da problemática urbana e as clivagens sociais no seio da própria sociedade urbana em constituição. Ao mesmo tempo há uma ampliação da noção de classes sociais ${ }^{5}$ em tensão, como também dos processos atuais quais derivam essas relações de tensão. Cabe ao Estado neste processo de revalorização, além de direcionar as formas de dominação e reprodução das classes sociais, também produzir novos conteúdos e novas representações para o espaço a partir da realidade e das condições que estão postas. Ao produzir um novo valor que é direcionado a um tipo específico de uso, o Estado produz também as condições para o surgimento de um novo valor de troca para o espaço, bem como a redefinição dos conteúdos que subsidiam o retorno da centralidade.

\section{Valorização do valor e o processo de reprodução do Centro de São Paulo}

A relação da forma-valor com o movimento da reprodução do Centro de São Paulo está atrelada a um tipo de produção que somente se realiza sob os fundamentos do capital e que apenas se realiza enquanto momento da produção ${ }^{6}$ do espaço.

\footnotetext{
${ }^{5}$ Conforme assevera (LEFEBVRE, 1973, p. 111), o fenômeno urbano em suas contradições internas é, simultaneamente o lugar da reprodução das antigas relações sociais como também o lugar da sua decomposição e o lugar da formação de novas relações sociais e das suas contradições. Ainda com base nas considerações do autor, ao lado da classe operária produz-se uma proletarização gigantesca que resulta dessa ampla decomposição. Com elementos conflituais novos. Se se define o proletariado pela ausência de laços jurídicos com os meios de produção, a proletarização afeta o mundo inteiro. Meus grifos.

${ }^{6}$ Conforme observamos em Marx (2013, p. 273), há uma dupla característica no processo de produção em que, primeiro, ao formar uma unidade entre os processos de trabalho e os de formação do valor, ocorre o processo
} 
Uma dupla perspectiva atravessa este tipo de produção na atualidade: primeiro, na generalização da propriedade privada do solo urbano que implicou no fenômeno da raridade do espaço no Centro de São Paulo; e, segundo, na estratégia e ação política do Estado, através da sua produção que é política. O momento de valorização do valor atravessa essas duas perspectivas e revela o espaço enquanto uma dimensão estratégica para a reprodução das relações sociais e a continuidade da diferenciação e dominação das classes também no espaço. $\mathrm{O}$ acumulo histórico de trabalho materializado no espaço, que produziu, definiu e imputou a identidade aos lugares, fez com que, no âmbito da generalização das trocas, este espaço socialmente produzido e suas relações ${ }^{7}$ se metamorfoseassem na forma-mercadoria. O espaço historicamente e socialmente produzido da metrópole e portador de trabalho acumulado, ao ser objeto do trabalho vivo - portanto, das condições e processos de trabalho ${ }^{8}$ que tem como objetivo a produção do espaço para a formação de um novo valor - torna-se também produto do processo de produção capitalista, e, em seus fundamentos, realiza-se também enquanto forma-mercadoria, ou seja, sob a primazia do valor de troca.

A reprodução do Centro de São Paulo compreende a sinergia entre Estado e capital, para fins de mobilizar todas as condições para que este fragmento da cidade, agora metamorfoseado em capital fixo, seja reproduzido e entre novamente na esfera da circulação. Nestes termos, seu processo de revalorização corresponde à produção de um novo valor de uso para o Centro (imbuído de novos conteúdos e representações), afinal, a valorização do valor somente existe no interior do movimento em que a circulação sempre renovada?

Suporte de valor e, ao mesmo tempo, portador de uma utilidade social - enquanto condição, meio e produto para a reprodução e realização da vida - o espaço também se torna um objeto da extensão do valor de troca, o que nos permite considerar uma dupla configuração morfológica: forma social (também forma natural) e forma de valor (já que sua utilidade social o torna necessário às condições de reprodução da sociedade); logo, portador de uma morfologia social e espacial.

de produção de mercadorias; e, segundo, através da unidade entre os processos de trabalho e de valorização, ele é processo de produção capitalista, forma capitalista da produção de mercadorias. Neste sentido, trabalho e valor, bem como o processo de valorização, tornam-se também fatores que estendem a forma-mercadoria para outras instâncias que compõem o real, conforme as condições que são históricas e que atualmente estão postas.

${ }^{7}$ Neste caso, levando em consideração três fatores sendo, primeiro, a cidade e o urbano (estes, fundamentados em seus conteúdos e dinâmicas históricas específicas, que tendem a caracterizar a reprodução também da vida cotidiana); segundo, o espaço (condição e meio para produção que permite a acumulação conforme as estratégias do capital); e, terceiro, através do Estado (que realiza a produção política do espaço e adquire centralidade estratégica na reprodução das relações capitalistas de produção por meio da reprodução das relações de dominação).

${ }^{8}$ Inclusive (e especialmente) aquele desenvolvido pelas frentes coordenadas pelo Estado.

${ }^{9}$ Marx, 2013, p. 228. 
Enquanto extensão do valor de troca, caracterizado através dessa morfologia social e espacial, o espaço tornado mercadoria expressa e exprime os conteúdos das novas contradições no capitalismo: ao mesmo tempo em que é homogêneo (em função das estratégias que o produz) é também fragmentado (para ser vendido aos pedaços) como também hierarquizado (por meio de uma prática do Estado que separa e garante a continuidade da reprodução). Extensão do valor de troca (resultado das necessidades de expansão do capitalismo enquanto condição da continuidade do regime de acumulação), ao ser conditio sine qua non para a reprodução da vida, o espaço é também portador de um valor de uso social que se torna a manifestação negativa do seu contrário ${ }^{10}$ (o valor de troca).

A reprodução do Centro de São Paulo carrega esses conteúdos do espaço socialmente produzido que entra (e se realiza) no circuito de produção e consumo das mercadorias. Contudo, a dinâmica da sua produção - caracterizada pelo processo de revalorização - passa a ser também determinada no âmbito totalizante da reprodução capitalista da metrópole. Dessa maneira, produção e reprodução capitalista do espaço revelam os conteúdos atuais do regime de acumulação, também caracterizados nas condições de reprodução das classes sociais, bem como na própria reprodução da metrópole.

Nestes termos de reprodução capitalista, a valorização diferenciada dos lugares da metrópole (assim como dos lugares em revalorização) continua também em função da reprodução classista que hierarquiza e distribui as classes sociais nos respectivos espaços da metrópole. A valorização diferenciada dos lugares se constitui também como um dos fundamentos do processo de segregação socioespacial que, determinado através dos imperativos da realização do valor de troca, inclui e exclui os sujeitos da cidade.

À luz das estratégias do capital ${ }^{11}$, o Centro em seus excessos torna-se um espaço com significativas possibilidades de realização do valor e, por conseguinte, uma tendência

\footnotetext{
${ }^{10}$ Valor de uso e valor de troca são duas dimensões contraditórias da forma valor que se realizam no âmbito do capitalismo através da sua contradição fundante. Somente há realização da troca quando aquilo que está posto à troca contém um fundamento que exige sua utilização em sociedade e, da mesma forma, somente aquilo que tem utilidade social tende a ser posto à troca (através dos diversos tipos de valor: relativa ou equivalente, particular ou desdobrada, universal e naturalizada na forma-dinheiro). Entretanto, no caso do processo de revalorização do espaço, a primazia de uma forma tende a retardar o processo de realização da outra. Por exemplo, a primazia do valor de uso torna-se o negativo do valor de troca e, diante do movimento da produção e acumulação capitalista, aquilo que está sob o valor de uso passa pelo processo de desvalorização ao não realizar o valor (de troca). Ou seja, no âmbito da produção capitalista, a extensão do valor de troca ao espaço somente se realiza quando este é posto (ou retornado) à esfera da circulação, através de novos conteúdos que imputam o novo valor de uso e que permitem pô-lo à venda, concretizando assim os demais momentos de troca e distribuição (para além da produção e do consumo).

${ }^{11}$ Levando em conta também que no âmbito da reprodução do capital os discursos e as ideologias das crises e do desvalorizado também são condições que permitem o empreendedorismo e as possibilidades de acumulação. Evidente que isso geralmente ocorre em situações que permitem a compra de algo a um preço baixo, para assim
} 
enquanto nova fronteira de acumulação da metrópole. Com o processo de revalorização, o Estado também ganha centralidade significativa ao conduzir as estratégias de intervenção que criam no espaço as condições que são imprescindíveis à reprodução econômica. Por meio de mecanismos específicos e estratégias de gestão, o Estado garante os anseios da classe dominante ao delimitar políticas (como também ao instituir os planos e normas) que transformam os lugares e definem/redefinem o processo de produção do espaço. No caso do Centro de São Paulo, estas estratégias do Estado revelam, por meio dos conteúdos das políticas públicas, alguns dos mecanismos específicos de reversão das condições que derivam da raridade do espaço enquanto um fenômeno urbano portador de uma contradição atual. Através de tombamento de edifícios ou do tombamento dos próprios espaços socialmente construídos $^{12}$ (para fins de preservar a identidade dos bairros, as áreas de interesse histórico, paisagístico e cultural) o Estado mobiliza os mecanismos e recursos necessários para assegurar que, por meio da manutenção da paisagem, a revalorização também se torne possível. Essa manutenção da paisagem assegura sua exclusividade e, ao mesmo tempo, uma identidade (portanto, uma representação do espaço), apenas no Centro da metrópole; ao ser considerada em sua condição de exclusividade, a paisagem (bem como tudo que a constitui) ganha a condição também de raridade, o que faz com que seu valor seja renovado sob estas condições.

Enquanto os distritos Sé e República são caracterizados pela escassez de espaço, seu entorno imediato dispõe de uma reserva significativa ${ }^{13}$, dotada de infraestrutura e carregada de condições para que a indústria do imobiliário realize uma nova fronteira de acumulação através da reprodução do Centro. Essa nova fronteira de acumulação deriva das próprias condições que foram postas atualmente diante do processo de revalorização do Centro de São Paulo. A escassez de espaço para a construção de novos empreendimentos referencia-nos diante dos procedimentos que são tomados por parte da PMSP para reverter (ou pelo menos tentar se apropriar das condições que até então tornam-se um impeditivo à reprodução do espaço). Ao mesmo tempo em que há lugares nos distritos Sé e República que são portadores de uma infraestrutura significativa, nestes também torna-se praticamente impossível a

produzi-lo (reproduzi-lo) e/ou transformá-lo e, por conseguinte, vender no preço de mercado. Um exemplo interessante são os imóveis que passam pelo processo de retrofit total.

${ }^{12}$ Por meio das Zonas de Preservação Cultural (ZEPEC), descritas no artigo $61^{\circ}$ do Plano Diretor Estratégico atual. No Plano, essas zonas são fragmentos do espaço destinados à preservação, valorização e salvaguarda dos bens de valor histórico, artístico, arquitetônico, arqueológico e paisagístico, doravante definidos como patrimônio cultural. SÃO PAULO (Município). Lei n 16.050, de 31 de Julho de 2014.

${ }_{13}$ Ainda mais se levarmos em conta que a densidade construtiva ainda é baixa e isto, à luz do setor imobiliário, torna-se um fator preponderante para a realização da compra de terrenos e suas possibilidades de remembramento, já que a compra de imóveis próximos também passam a interessar. 
obtenção de espaço disponível para a construção de novos empreendimentos, pelo menos neste momento da história. A saída encontrada para este quadro de escassez de espaço pode ser compreendida a partir de uma alternativa que é constituída de duas possibilidades: 1) se apropriando desta escassez, assegurar (ou mesmo produzir) uma condição de exclusividade a partir da raridade, similar à obra de arte; 2) se apropriar das condições que permitem expandir a noção de Centro para os bairros que compõem os distritos do entorno Sé e República, principalmente atribuindo a estes a identidade (portanto, as representações do espaço) que é atribuída aos distritos Sé e República como espaços que caracterizam o Centro (principalmente o Centro Histórico) de São Paulo.

Ao garantir que as condições para a manutenção e reforma das estruturas urbanísticas se torne possível, as condições para o reforço das representações do espaço ligadas à cultura também passam a ter um importante significado neste processo de revalorização. Assim, produção política do Centro de São Paulo se realiza por meio de estratégias que asseguram novas ideologias, bem como novas representações para o espaço, tais como cultura, polo de moda e economia criativa, que são algumas delas. Através desses álibis, que são estruturados a partir da cultura, o Estado objetiva produzir instrumentalmente e politicamente o espaço por meio de formas de organização, controle, regulamentação, direcionamento e manipulação. Essas ações são estratégias e se realizam no sentido de subordinar os recursos do espaço aos seus objetivos políticos que, por sua vez, também coadunam com os objetivos políticos das classes que veem no espaço uma condição e meio para a acumulação. Neste plano político que caracteriza a reprodução-revalorização do Centro de São Paulo, há um movimento que vai do álibi cultural (aquele estruturado e construído a partir da cultura) para uma realização da cultura como negócio, fato que reduz brutalmente a dimensão cultural.

No plano econômico, no Centro e nos distritos que compõem seu entorno, o aumento gradual do preço do metro quadrado do espaço (anexo 01 e 02) expõe o movimento progressivo de sua revalorização. Alguns novos empreendimentos - compactos onde o espaço é mais rarefeito e amplos, tamanho padrão, onde o espaço tende à possibilidade da abundância - caracterizam a incorporação de novos edifícios que transformam os lugares, já com as novas identidades que estão sendo construídas. Praticamente duas frentes formam, atualmente, o cerne que põem em prática o processo de revalorização: 1) o Estado, por meio das estratégias que se realizam tanto nas políticas urbano-territoriais, quanto por meio da afirmação das identidades (culturais, comerciais, econômicas e turísticas); e 2) por meio dos novos empreendimentos que passam a ser pioneiros sob os discursos de revitalização e revalorização do Centro de São Paulo. Estas duas frentes surgem como novas medidas que visam transpor 
as fronteiras entre os bairros e distritos ao entorno do Centro, como também transpor as fronteiras e limites dentro dos próprios bairros e distritos, neste caso, por meio das transformações das representações atribuídas ao espaço.

Valorização, desvalorização e revalorização, atrelados ao movimento de produção do espaço, revelam a forma de descontinuidade no tempo e no espaço em que, no momento atual, determinam a imposição dos conteúdos da mundialização e caracterizam o processo de revitalização urbana desenvolvido pela Prefeitura Municipal de São Paulo. Contudo, vale salientar que a revitalização posta em prática pela PMSP, ocorre, praticamente, desde meados da década de 1970 e, em meados da década de 1980, as intervenções para a revitalização do Centro passam por transformações significativas. A partir da década de 1990 elas deixam de ser predominantemente pontuais e passam a ser realizadas através de territórios estrategicamente delimitados para abrangerem a área de todo o Centro. Deste modo o processo de revalorização do espaço confere, por um lado, o movimento em que "a produção imobiliária, como condição de aplicação de capital, redefine o sentido do espaço que assume também, e preferencialmente, a condição de capital fixo" (CARLOS, 2015, p.54); e, por outro, o processo de desvalorização, inerente em função da localização do fragmento do espaço no conjunto da cidade ${ }^{14}$. Contudo, outro fator também caracteriza e torna-se preponderante ao processo de desvalorização em função da metrópole condicionalmente transformada em capital fixo ${ }^{15}$. O processo de revalorização, além de vir a reboque das intervenções estratégicas do Estado, caracteriza também o momento em que a indústria do imobiliário $^{16}$ se apropria dos conteúdos das novas representações atribuídas ao espaço para lançar seus empreendimentos com a mesma identificação do/no lugar. A partir desse momento, capital e Estado compõem uma parceria que corrobora com a produção de um novo valor de uso para o espaço, portanto, realizando um processo de valorização do valor através da reprodução do Centro.

Valor de uso e valor de troca movem a contradição constante no capitalismo, tanto que a primazia temporária da troca torna-se o momento crítico do uso. Concordando com (DUSSEL, 2012, p. 187) que afirma que a "desvalorização é um momento essencial do ser do capital, do capital em geral, dos capitais concretos [e] dos ramos de produção", a produção do espaço, enquanto momento e dimensão concreta de realização do capital, se realiza em função da primazia do valor de troca fundamentando o espaço-mercadoria. Assim, tornado condição

\footnotetext{
${ }^{14}$ Carlos, 2011, p. 100.

${ }^{15}$ Carlos, 2015, p. 54.

${ }^{16}$ Neste caso, já consolidada e caracterizada pelas estratégias que coadunam com as ações do Estado.
} 
e meio para a reprodução da metrópole ${ }^{17}$, é na cidade e no urbano que o espaço socialmente produzido se desvaloriza ao mesmo tempo em que outros espaços passam pelo processo de valorização. Nestes termos, o movimento que se realiza e que tende a revalorização, expressa o conflito e os interesses das classes sociais pelo Centro de São Paulo. De um lado, uma burguesia ligada à indústria do imobiliário que verifica neste fragmento a possibilidade de acumulação; do outro, o proletariado atual da metrópole que, cada vez mais, vem ocupando e se apropriando do Centro de São Paulo para dar continuidade à vida. Essa nova dinâmica conflitiva entre classes sociais distintas deriva, a nosso ver, de uma burguesia e pequenoburguesia $^{18}$ em ascensão, cuja acumulação deriva do setor imobiliário e a produção torna-se cada vez mais significativa na metrópole. Segundo um balanço do Secovi, somente no ano de 2013 um total de 33,3 mil unidades comercializadas na metrópole paulistana gerou um montante de 20,5 bilhões comercializados na cidade. No ano de 2014, por mais que houvesse uma queda, o total comercializado girou em torno de 11,9 bilhões de reais. Conforme há o avanço significativo do setor imobiliário, há também uma correlação significativa de setores da economia (de agentes financiadores a incorporadores imobiliários) para que, cada vez mais, novas unidades, bem como novas mercadorias imobiliárias, possam entrar novamente no mercado e mobilizar quantidades ainda maiores neste setor. Com aportes de indústria, o setor imobiliário atua de maneira significativa no processo de reprodução da metrópole e, em meio a valorização diferenciada dos lugares, analisa e traça estratégias para verificar em quais fragmentos da metrópole o processo de acumulação a partir da produção do espaço se potencializa com mais eficácia.

Se por um lado esta atividade produtiva ganha novos significados a ponto de nos apontar para um novo setor industrial e, ao mesmo tempo, a formação de uma nova parcela de burguesia (bem como uma pequeno-burguesia) ligada a este setor, por outro, podemos considerar, a partir desta mesma situação, o surgimento (ou mesmo a consolidação) do proletário no atual momento da metrópole. Marx e Engels (2010, 2011) avaliam o proletariado como aquele que é o sujeito despossuído em relação a qualquer forma de propriedade privada em que a manutenção desta enquanto riqueza se realiza a partir da sua antítese, o proletariado. Com o advento desta que podemos considerar uma realidade metropolitana, o sujeito despossuído do século XXI - que é o mesmo que também compõe os conteúdos da própria sociedade urbana, bem como sua problemática - é marcado também

\footnotetext{
${ }^{17}$ Carlos, 2011a, p. 62.

18 Neste caso, naqueles indivíduos que fazem parte das classes gerenciais ligadas ao setor imobiliário na metrópole paulistana.
} 
pela sua relação de despossessão, tanto da metrópole quanto da vida urbana. Neste caso, despossuído até do espaço (socialmente e historicamente produzido ${ }^{19}$ ), para este somente restou residir (ou mesmo ocupar) os extremos ou os espaços mais inóspitos das grandes metrópoles. A partir do momento em que houve no Centro o processo de desvalorização e uma quantidade expressiva de imóveis vagos ou subutilizados, estes sujeitos (marcados pelas diversas cargas que caracterizam o processo de urbanização na atualidade) passaram a ocupar (ou mesmo se manterem no lugar resistindo os processos de expulsão) o Centro da metrópole paulistana. Ao se apropriarem deste espaço, bem como das suas condições, puderam, mesmo que em diversas situações sob os desígnios da precariedade, dar continuidade às suas respectivas vidas e a relação com os novos postos de trabalho que estão surgindo, mesmo que também sob condições precarizadas.

A reversão da desvalorização se realiza enquanto uma forma de reverter também o fenômeno da raridade do espaço na metrópole de São Paulo. O processo de reprodução do Centro de São Paulo se realiza atualmente através de estratégias políticas que orientam e produz o espaço através da produção de seu novo valor de uso. Neste movimento, o Centro e seu entorno se metamorfoseiam em capital fixo ${ }^{20}$ na medida em que, aos poucos, estes entram novamente no processo de produção. É o momento em que o espaço entra neste processo como meio, e não mais como produto; é também o momento em que o trabalho vivo vai incorporando novos conteúdos no lugar. Essa incorporação de trabalho no espaço produz um novo valor que tende a ser apropriado privadamente.

\footnotetext{
${ }^{19}$ Pelo fato deste espaço também passar a fazer parte da própria produção, seja como capital fixo (portanto, levando em conta todas as estruturas que são fixadas neste espaço) ou seja como força produtiva, em que as condições postas e dadas tornam-se preponderantes e necessárias para a produção do espaço num contexto em que ocorre também a reprodução da metrópole.

${ }_{20}^{20}$ Este movimento, ou mesmo esta metamorfose de qual estamos comentando, advém daquilo que consideramos em função da própria noção de Capital Fixo. Nas considerações feitas por Marx (2011), o capital fixado é aquele que se encontra já em estágio de desvalorização, ou seja, a partir do momento em que o mesmo não se realiza na circulação (não percorrendo também as fases que ele deve percorrer para que o valor se valorize) ocorre que sua produção encontra-se em estágio de limitação. No caso do espaço socialmente e historicamente produzido isso se torna central ao entendimento, afinal, a partir do momento em que o mesmo está se realizando sob os determinantes do valor de uso, não há como o mesmo passar pelas outras fases que determinam a realização do valor (produção, distribuição, troca, consumo). As próprias condições de produção permanecem em sua forma marcada pelo uso, bem como a constituição de seus valores, e, enquanto condições, estas se constituem praticamente como um impeditivo ao ingresso deste no processo de produção. Neste sentido, levando em conta todas as caraterísticas e qualidades que fazem com que o espaço seja caracterizado por este valor de uso, este espaço historicamente e socialmente produzido do Centro de São Paulo torna-se, praticamente, um capital fixado e preso nas condições que atribuem seu uso. Ao mesmo tempo, o próprio uso em si já aponta uma forma de valor socialmente produzida e utilizada que lança sua tendência e potência de realização enquanto valor de troca. Basta esta tendência potencialmente avaliada para que este mesmo espaço seja também objeto de interesse para se realizar através dos circuitos da produção e, ao mesmo tempo, fomentar a possibilidade de retornar à esfera da circulação e se redefinir conforme a prevalência do valor de troca sobre o uso. No caso do Centro, a reversão destas condições de fixação deriva dos artifícios que buscam anular esta fase da "imobilidade" e, neste caso, através das políticas urbano-territoriais desempenhadas pelo Estado.
} 


\section{CAPítulo I - ValorizaÇão-DesvalorizaÇão-ReValorizaÇÃo do CENTro de São Paulo}

A revalorização do Centro de São Paulo revela a tendência mundial de uma lógica homogeneizante que se realiza enquanto movimento de reprodução do espaço. O processo de urbanização que se concretiza ininterruptamente na transição do século XX para o século XXI, revela as tendências desta reprodução através de fatores, estratégias e modelos de reprodução que se realizam em escala mundial, porém, adquirem suas particularidades na escala do lugar. As relações que ocorrem na escala do lugar adquirem complexidade conforme são compreendidas no âmbito de suas metamorfoses, afinal, estas não ocorrem apenas em função do espaço e para sua compreensão, há também a exigência da interpretação das relações temporais marcadas por formas de descontinuidade ${ }^{21}$. Na esfera das metamorfoses por qual passa o Centro das cidades, as interpretações do movimento de reprodução, como também das contradições que o atravessa, ganham potência ao serem decifradas à luz dessas descontinuidades que ocorrem tanto no espaço quanto no tempo. Levando em conta as metamorfoses atuais como resultados de um processo de reprodução do espaço $^{22}$, a tríade valorização-desvalorização-revalorização ilumina o trajeto e projeta a análise em direção aos conteúdos e contradições da reprodução social na atualidade, que se revelam enquanto reprodução do espaço.

A descontinuidade espaço-temporal inerente à reprodução do Centro de São Paulo é concebida através dos momentos de valorização e desvalorização, sendo que este último passa a ser concomitante ao processo de revalorização; tais momentos tem como chave de interpretação e análise o processo de industrialização que explodiu a cidade de São Paulo, efetivando também o movimento que produziu a metrópole. Em São Paulo a industrialização induziu significativamente a urbanização e o surgimento da metrópole enquanto fato histórico, através de um movimento de transição de fases de acumulação. Ou seja, o período que deixa de ser marcado por uma atividade econômica ligada à aristocracia cafeeira (herança histórica do passado brasileiro) apontou a transição para o período da produção industrial e, consequentemente, da intensificação do processo de urbanização. Enquanto um fenômeno de produção em larga escala, a industrialização induziu o processo de urbanização e posteriormente - como resultado de sua própria dinâmica - determinou o deslocamento das

\footnotetext{
${ }^{21}$ Neste caso, descontinuidades espaço-temporais relacionadas aos momentos de valorização, desvalorização e revalorização do espaço.

${ }^{22}$ Mais uma vez vale salientar a similaridade das estratégias de revalorização dos Centros das cidades que ocorrem na escala mundial, ainda mais levando em conta o caso de Barcelona que se tornou um modelo para os processos que ocorreram posteriormente.
} 
suas unidades de produção industrial para a periferia da metrópole e, sucessivamente, depois, para outros espaços.

Em São Paulo, na transição do século XIX para o século XX, a produção em escala ampliada foi suprimindo a produção "artesanal" ou primeira (inclusive na produção da cidade), e, em função da industrialização, a relação dos indivíduos com a cidade também foi se metamorfoseando. A industrialização, como fenômeno indutor, implode aos poucos as antigas relações que caracterizavam a cidade ${ }^{23}$. A produção em larga escala foi se realizando e se potencializando sob os fundamentos da forma-mercadoria, fato este que explodiu gradualmente as antigas relações e, ao mesmo tempo, acentuou os conteúdos das novas relações sob os fundamentos do valor de troca e, consequentemente, da cidade. Assim, por meio de sucessivas metamorfoses, o antigo valor de uso da cidade, passou a ser subordinado pelo novo valor de troca, cada vez mais fixado ao espaço, sob as mais diversas forma, inclusive por meio da vida cotidiana.

Do espontâneo-histórico ${ }^{24}$ ao espaço estratégico, o Centro é portador de uma dialética que vai do cultural-comercial das elites (no início do século) para o Centro que reúne os elementos do poder (com a concentração das instituições do Estado em meados do século XX); do Centro abarrotado pelos conteúdos da urbanização para o Centro da raridade efetiva do espaço. A raridade do espaço no Centro explicita também a disputa por aquilo que é e está raro. Alguns aspectos ajudam a vislumbrar este movimento da explosão-implosão: a) sob a industrialização a cidade explode e, conforme a história se realizou, ela se tornou metrópole; b) ao se tornar metrópole industrial e induzida pelo processo de industrialização, o Centro ganhou sua centralidade econômica; c) o espaço, sob a condição de espaço abstrato, principalmente no Centro, tornou-se o espaço de poder ao mesmo tempo em que despontou o espaço como um instrumento de poder; d) o Centro é também resultado de um processo de oposições espaço-temporais (negação tanto do espaço quanto do tempo passados); e) na

\footnotetext{
${ }^{23}$ A última década do século XIX e, praticamente, as três primeiras décadas do século XX caracterizou um período em que houve um movimento de negação do passado histórico rural que levou a um conjunto de condições que também serviram para a diferenciação das classes no espaço, inclusive com a transformação do próprio espaço. A atividade industrial aos poucos foi tomando conta da cidade transformando-a significativamente, caracterizando uma relação de complementaridade em que a vida urbana exigiu o surgimento da indústria para dar conta da demanda exigida pela mudança dos hábitos cotidianos na cidade. A realidade urbana exigiu a produção em larga escala de tudo que era consumido cotidianamente naquele momento e a indústria vai apoderando-se pouco a pouco desta realidade. O advento dos estabelecimentos da indústria de transformação para abastecer a cidade tornou-se uma tendência que, posteriormente, se consolidou conforme a estrutura da morfologia urbana e as exigências do processo de urbanização.

${ }^{24}$ Espontâneo no sentido de ter ocorrido enquanto uma forma de negação, nesse caso, uma negação da herança e predomínio do campo e do modo de vida rural; sem uma acepção prévia ou mesmo um planejamento para que viesse a ocorrer uma mudança significativa das elites para a cidade. Histórico, por sua vez, pelo fato desta transição ter marcado um momento da história e ter representado uma forma de ruptura de uma classe da sociedade; ruptura essa caracterizada pela considerável fixação de estruturas, formas e funções no espaço.
} 
atualidade, o processo de negação ocorre enquanto um processo de revalorização, que se realiza por meio da produção de um novo valor de uso para o Centro.

O processo de valorização do Centro de São Paulo, enquanto momento constitutivo e necessário de uma dialética espaço-temporal de sua reprodução, é caracterizado por sua arquitetônica europeia que foi capaz de produzir e marcar uma forma de vida urbana e seus ritmos, da mesma maneira que também se constituiu enquanto espaço de uma representação específica $^{25}$. O processo de produção do Centro foi marcado por um traço arquitetônicourbanístico que imprimiu ao espaço uma identidade que se realizou enquanto um processo de negação do rural, através da produção de um espaço carregado de representações urbanas. Tais representações e identidades que foram expressivas através do espaço, tornaram o Centro de São Paulo em um espaço definido por conteúdos específicos ao consolidar estas estruturas e formas urbanas, bem como as relações que se davam em função delas.

Definido pelos conteúdos do processo de urbanização daquele momento (final do século XIX e início do século XX), e definitivo em função das suas estruturas urbanas, o Centro tornou-se também um espaço definidor ${ }^{26}$, tanto das práticas socioespaciais quanto do próprio movimento de sua produção, atraindo para si uma centralidade inerente à explosão da cidade. Contudo, toda centralidade imputa e exige sua destruição ou mesmo autodestruição e, assim, a partir desse momento, uma nova representação se cria através de um novo movimento de superação que o engoliu e o atribuiu uma nova representação. Isto quando a industrialização tomou de assalto a cidade e as relações sociais passaram a ser em torno do valor de troca, tanto a Cidade (explodida-implodida) quanto o Centro também passaram a ser o objeto direto das sociabilidades que se realizaram nesta condição: este foi o momento em que o Centro paulistano ganhou sua centralidade econômica e passou a ser valorizado sob os imperativos da forma-mercadoria.

\subsection{A EXPLOSÃO DA CIDADE INDUZIDA PELA INDUSTRIALIZAÇÃO: A IMPLOSÃO DO CENTRO E A SUA CENTRALIDAde EM SÃo Paulo}

Com o passar dos anos as transformações da cidade foram influenciando, também aos poucos, os conteúdos do Centro de São Paulo e acentuando, cada vez mais, tanto sua

\footnotetext{
${ }^{25}$ Representação, por um lado, do poderio de uma classe que ao acumular significativamente fez questão de dispender quantias significativas de suas riquezas com a "ornamentação" da cidade, através da produção arquitetônica mimetizada aos moldes da arquitetônica europeia. Por outro, para fixar no espaço as estruturas que representam o poderio e a prevalência de uma classe que faz questão de negar o passado rural construindo a cidade, produzindo assim um novo espaço que anule, mesmo que aos poucos, a representação da herança rural.

${ }^{26}$ No sentido de um espaço socialmente produzido que define e direciona as práticas socioespaciais dos indivíduos.
} 
centralidade quanto o espaço de dominação. Müller (1958) ao elencar algumas funções do Centro destacou o diferencial deste fragmento de São Paulo que já se estendia do Núcleo Antigo (localizado na colina central) para além do Vale do Anhangabaú, sentido Praça da República, considerado pela autora como o Núcleo Novo. Os estudos em geografia urbana naquele momento eram caracterizados pelas monografias que descreviam o grau e a intensidade das funções e, nesse caso, Müller destacou algumas funções que permitiram compreender as transformações que foram ocorrendo no Centro de São Paulo, sendo: 1) a função comercial; 2) a função industrial (em relação à pequena indústria), onde se localizam as profissões liberais; 3) a função financeira; e, 4) a função administrativa (na figura do Palácio do Governo e das Secretarias de Estado).

No Centro exacerbavam-se cada vez mais os conteúdos do processo de urbanização e a reboque concretizava-se também a sua valorização, conforme se acentuava sua centralidade na metrópole, quando esta se afirmava enquanto metrópole industrial. Após o adensamento populacional $^{27}$ entre 1890 e 1900 , a atividade industrial inicial transformou por completo as relações sociais, para ganhar potência e se expandir. Na década de 1920 ampliou-se consideravelmente a população da cidade, mudou-se os costumes, quando foram transformados em constância, conforme uma linearidade de um tempo que se repetia cotidianamente e que possuía um novo frenesi. Da década de 1920 até a década de 1950 alguns fatos marcaram este que período em que a cidade se tornou metrópole. Primeiramente houve a consolidação do capitalismo (bem como suas relações e formas de sociabilidade) através da atividade industrial que se realizou na cidade e que, anos mais tarde, essa mesma atividade passou a caracterizar-se por meio de formas da produção que se tornara cada vez mais mundializada. Os primeiros 50 anos do século XX marcaram significativamente o surgimento e a consolidação da indústria de transformação em São Paulo.

Pasquale Petrone (1958) destacou alguns fatores ${ }^{28}$ que contribuíram para o advento e consolidação do parque industrial paulistano, ao mesmo tempo em que apontou alguns fatos

\footnotetext{
${ }^{27}$ Adensamento que ocorreu, predominantemente, entre o final do século XIX e início do século XX. Conforme os dados de Aroldo de Azevedo, a cidade de São Paulo apresentou em 1890 um total de 64.934 habitantes, em 1900, 239.820, vinte anos depois, em 1920 um total de 579.033 habitantes; já em 1940 a cidade atravessa seu primeiro milhão, totalizando 1.318 .539 habitantes; em 1950 chegou a marca de 2.198 .096 habitantes, quase dobrando a população em apenas 10 anos. De 1890 para 1900 há o crescimento de cerca de 72,92\%, o que deu uma média de 3,6\% ao ano. Já de 1900 para 1920 a cidade cresceu 58,58\%, com uma média anual de 2,9\%. O que ocorreu de forma parecida no período que compreendeu entre 1920 e 1940 com 56,08\% e uma média anual de 2,8\%. Diferentemente ocorreu entre os anos de 1940 e 1950 em que a cidade cresceu 40,01\% e totalizou uma média anual de $4,0 \%$.

${ }^{28}$ Petrone (1958) destaca uma série de fatores que ocasionou o desenvolvimento e o fortalecimento do parque industrial paulistano: 1) a facilidade de obtenção de energia elétrica, que somente nos últimos anos (provavelmente no final da primeira metade do século XX) passou por um período de escassez, o que, nas
} 
mundiais $^{29}$ que contribuíram com o desenvolvimento do capitalismo no Brasil e mais especificamente em São Paulo. No que tange a particularidade conjuntural do país, devemos destacar que a indústria de transformação neste período de transição do século XIX para o século XX ainda caracterizava a pequena produção ${ }^{30}$, contudo, que propiciou num período de 80 anos uma mudança que não ocorrera nos últimos 325 anos (tabela 01).

Tabela 1 - População nos anos de levantamento censitário, 1872 e 1970. Município de São Paulo, Região Metropolitana de São Paulo e Estado de São Paulo

\begin{tabular}{|c|c|c|c|c|c|c|}
\hline \multirow{2}{*}{ Anos } & \multicolumn{2}{|c|}{ Município de São Paulo } & \multicolumn{2}{|c|}{ RMSP } & \multicolumn{2}{|c|}{ Estado de São Paulo } \\
\hline & Pop. & $\begin{array}{c}\text { Tx de } \\
\text { Cresc_to }{ }^{(l)}\end{array}$ & Pop. & $\begin{array}{c}\text { Tx de } \\
\text { Cresc_to }{ }^{(1)}\end{array}$ & Pop. & $\begin{array}{c}\text { Tx de } \\
\text { Cresc_to }^{(1)}\end{array}$ \\
\hline \multirow[t]{2}{*}{1872} & 31.385 & & - & & 837.354 & \\
\hline & & 4,1 & & - & & 2,8 \\
\hline \multirow[t]{2}{*}{1890} & 64.934 & & - & & 1.384 .753 & \\
\hline & & 14,0 & & - & & 5,1 \\
\hline \multirow[t]{2}{*}{1900} & 239.820 & & - & & 2.282 .279 & \\
\hline & & 4,5 & & - & & 3,6 \\
\hline \multirow[t]{2}{*}{1920} & 579.033 & & - & & 4.592 .188 & \\
\hline & & 4,2 & & - & & 2,3 \\
\hline \multirow[t]{2}{*}{1940} & 1.326 .261 & & 1.568 .045 & & 7.180 .316 & \\
\hline & & 5,2 & & 5,3 & & 2,4 \\
\hline \multirow[t]{2}{*}{1950} & 2.198 .096 & & 2.622 .786 & & 9.134 .423 & \\
\hline & & 5,6 & & 6,1 & & 3,6 \\
\hline \multirow[t]{2}{*}{1960} & 3.781 .446 & & 4.739 .406 & & 12.974 .699 & \\
\hline & & 4,6 & & 5,6 & & 3,2 \\
\hline 1970 & 5.924 .615 & & 8.139 .730 & & 17.771 .948 & \\
\hline
\end{tabular}

Fonte: IBGE, Censos Demográficos e PMSP.

(1) Taxa de crescimento geométrico anual

Elaboração: Gilmar Soares, 2014.

palavras do próprio autor, criou um problema angustiante; 2) a existência de um mercado consumidor interno, que se tornou cada vez maior em virtude do crescimento da população da cidade e do Estado; 3) o afluxo de capitais, tanto estrangeiros como nacionais, possibilitando o aparecimento de grandes indústrias; 4) a facilidade de mão de obra operária, a princípio oriunda da massa imigrada, mais tarde resultante da crise cafeeira de 1929-1930; 5) a existência de um mercado fornecedor de matérias-primas, dentro do próprio Estado (no que se refere ao algodão, notadamente) ou fora dele; 6) a importante rede de transporte, que tem na cidade de São Paulo seu fulcro (p.102). Meus grifos.

${ }^{29}$ Entre os fatos podemos destacar alguns acontecimentos mundiais, como: 1) a primeira Grande Guerra (19141918); 2) a crise econômica decorrente do "crack [da bolsa de Nova Iorque]" e; 3 ) a última conflagração mundial [Segunda Grande Guerra] (1939-1945).

${ }^{30}$ Segundo Martins (2013, p.217-219) houve, particularmente em São Paulo, um potencial de criatividade empresarial e industrial que se aproveitou da demanda intersticial de produtos industriais que não eram atendidas pela importação. O período do reinado do café imprimiu à sociedade brasileira uma capacidade de consumo que ultrapassou a capacidade de importação, fato que não significa substituir as importações. Assim, segundo o autor, a gênese da indústria brasileira deve ser compreendida no seu vínculo ao complexo de relações e produtos que não devem ser reduzidos ao binômio café-indústria. Era uma indústria do padrão do artesanato e da manufatura, de pequena escala, mas disseminada pelo país inteiro, localista, protegida pela insuficiência e pela precariedade das vias de comunicação contra as mercadorias desembarcadas nos portos, que dependiam do demorado e muitas vezes precário transporte para chegar aos compradores finais. Nem mesmo a rede ferroviária foi suficiente para quebrar a importância dessa economia industrial pré-moderna. A circulação restrita do dinheiro, a população pobre consumidora desta indústria faziam com que ela não operasse com as regras do capital industrial. Essa análise da indústria feira por José de Souza Martins está inserida no debate da industrialização no Brasil entre o fim do século XIX e início do século XX. 
A transição do século XIX para o século XX fez germinar as condições para que entre a década de 1950 e 1960 o surto industrial, oriundo da expansão do capitalismo mundial, tomasse São Paulo de assalto e a explodisse de vez, implodindo e acentuando seus conteúdos a esta nova ordem. Houve que a cidade foi produzida sob condições de ser o suporte para a produção em larga escala e que, neste mesmo período, imputou novas problemáticas para além daquelas que vinham da realidade do capital industrial.

Em termos mundiais, os mercados marginais da periferia do capitalismo passaram a interessar aos novos capitais industriais nesta fase tardia do regime de acumulação, e a ordem distante cumpria com seu papel em mundializar a produção em larga escala de mercadorias ${ }^{31}$. Com a explosão da cidade e a extensão do seu tecido urbano, o Centro passou a ter sua centralidade formada em função do espaço que se tornou rarefeito ao seu redor. A centralidade econômica se diferenciou da centralidade comercial - formada no movimento de redefinição dos sentidos do Centro da cidade de São Paulo - assim como também se diferenciou dos significados da cidade como um todo. O momento também compreendeu a afirmação de um processo em que o urbano (por meio dos conteúdos que caracterizam a cidade em si) passou a ser definido como a própria centralidade, quando se tornou referência para a centralidade produtiva, necessária do capitalismo e de sua reprodução naquele momento da história.

A indústria que surgiu para suprir a demanda do processo de urbanização em latência na primeira metade do século XX mantém sua continuidade e movimento de expansão, contudo, ainda não teve naquele momento condições suficientes para acumular capital somente em função da sua atividade. Nesse momento inicial, o setor industrial ainda estava na dependência da atividade econômica cafeeira para continuar seu processo expansivo e, ao mesmo tempo, dependia do desenvolvimento das condições internas de consolidação de um mercado consumidor que estava se formando. O curso simultâneo entre as forças produtivas da indústria de transformação capitalista e a atividade produtiva cafeeira se realizou até o início da década de 1930 (em função da crise de 1929), fazendo com que a continuidade da acumulação se concentrasse apenas na atividade industrial.

Uma crise do capitalismo e uma guerra mundial marcam esse período que vai até meados da década de 1950, que Tavares (1985, p.103) avaliou como industrialização restringida (período de recuperação econômica e aceleração do crescimento industrial gerados

\footnotetext{
31 Após a crise do capitalismo desencadeada no final do século XIX e, posteriormente, a crise que foi desencadeada na transição da década de 1920 para a década de 1930, novos espaços necessários à expansão do capitalismo passaram a ser objeto direto dos interesses direcionados para a também expansão da indústria bem como as relações de produção e consumo que derivavam de toda sua estrutura.
} 
por um movimento endógeno de acumulação). Para a autora dois fatores caracterizaram essa dinâmica: a) um segmento urbano de renda; e b) o desenvolvimento das forças produtivas e o suporte interno de acumulação urbana ${ }^{32}$. Entre as décadas de 1920 e 1960 a taxa de crescimento da cidade de São Paulo aumentou em proporções significativas; se nos 20 primeiros anos ocorreu o aumento de 4,2\% da população, na terceira década do século XX o aumento foi de $5,2 \%$ e, por fim, o aumento de 5,6\% no último período desta fase marcado na década de 1960.

Figura 1 - À esquerda, Distrito Sé (Centro "Velho") e Distrito República (Centro "Novo"). Década de 1960

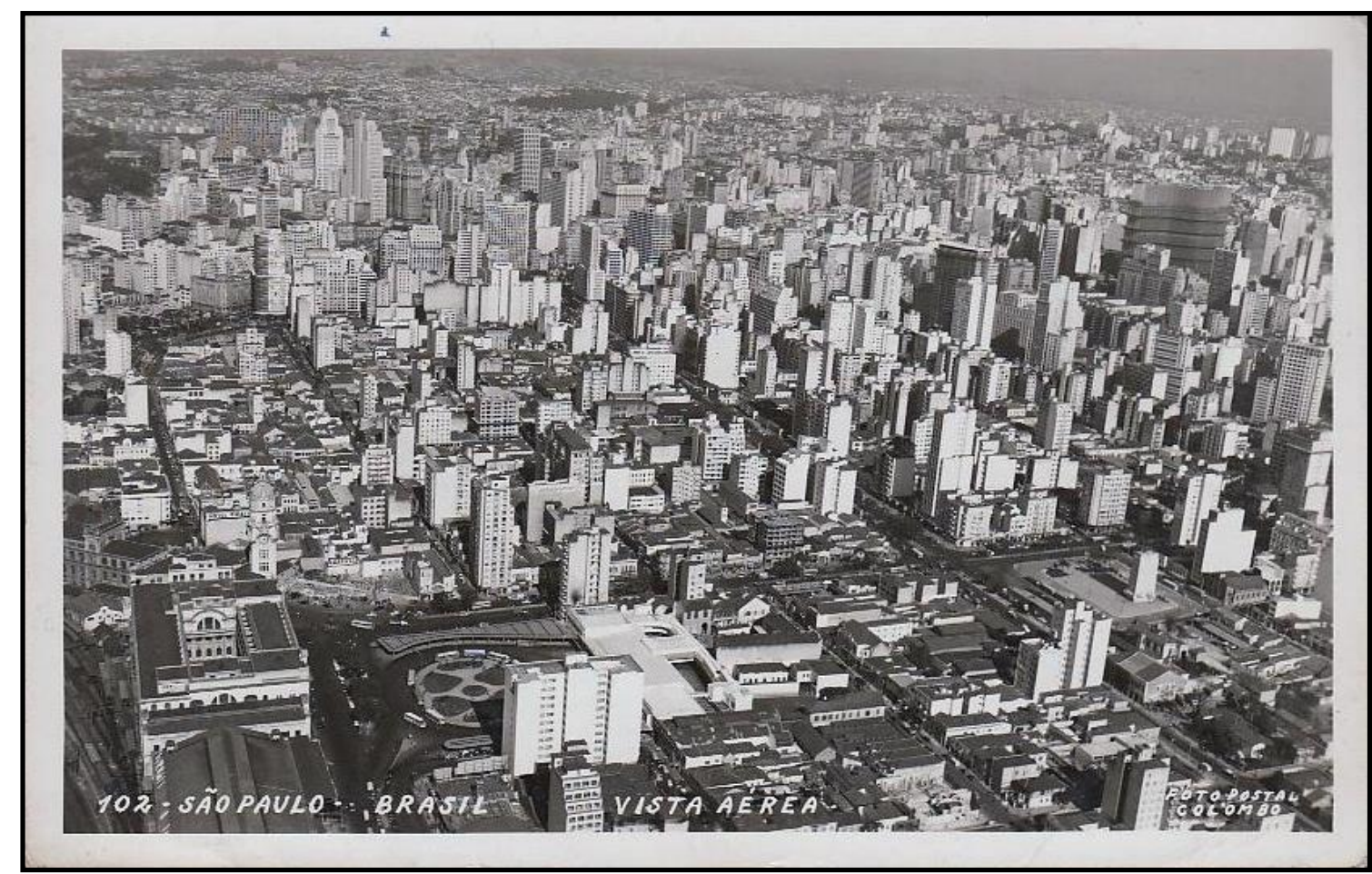

Fonte: https://sampahistorica.files.wordpress.com/2014/12/1960-vista-ac3a9reacentro-julio-prestes-e-altino-arantes-fcp-dcp.jpg Acessado em Maio de 2015.

O crescimento significativo da cidade, que refletiu na explosão de sua morfologia espacial, deve ser atrelado à dinâmica de instauração do capitalismo industrial, cujas unidades de produção também contribuíram com o processo de dispersão na metrópole. Se no início do processo de consolidação da produção industrial as unidades produtivas eram localizadas na área central da cidade, ao logo do tempo e conforme houve o processo de dispersão/expansão

${ }^{32}$ Tavares, 1985, p.103. 
da periferia, a indústria de transformação na cidade de São Paulo localizou-se às margens da linha férrea ou nas suas proximidades. Conforme houve o movimento de instalação das unidades produtivas, houve também, em suas proximidades, o surgimento das vilas industriais e dos bairros predominantemente ocupados pela classe operária. Com o predomínio do transporte rodoviário, a dinâmica se alterou e a indústria passou a ocupar outros espaços que não mais se localizavam mais às margens da linha férrea. A atividade industrial passou a ser realizada ao longo das marginais dos rios Tietê e Pinheiros, ocupando os terrenos de várzea da zona sul, à zona oeste da cidade e à zona norte de São Paulo.

Apesar da estagnação pela demanda de espaço que ocorrera anteriormente, as indústrias passaram a ser de menor porte, o que, consequentemente, exigiu a menor demanda por espaço e foi este perfil de estabelecimento que também ocupou as margens retificadas dos

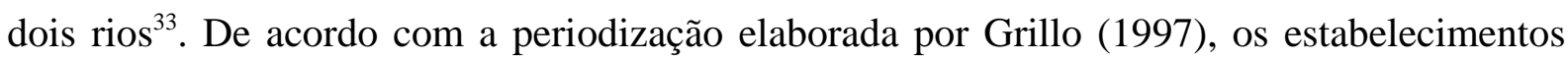
industriais de grande porte que se localizavam na cidade de São Paulo realizaram suas respectivas produções até a década de 1950 (período caracterizado pela construção das grandes vias) em função da demanda dos espaços e da possibilidade de realizar ainda estas produções em larga escala. Ainda com base nas considerações da autora e a título de exemplo, podemos considerar o caso da Ford que funcionou no bairro do Bom Retiro de 1919 até 1953, e a Scania-Vabis que, posteriormente, se instalou na região do ABC. A partir dos anos 1970, houve a consolidação da ocupação industrial no espaço urbano da metrópole, sendo a margem esquerda do rio Pinheiros (do loteamento Jurbatuba até Guarapiranga) um espaço de grande concentração de indústrias.

A industrialização produziu algumas condições que foram significativas para que a cidade explodisse transformando-se, posteriormente, em metrópole, em função das próprias condições históricas. Ao produzir a metrópole, a industrialização produziu também seus conteúdos, suas contradições e seu proletariado e, ao mesmo tempo, as condições de sua própria reprodução, conforme fosse reproduzindo também seu espaço. O capitalismo tomou de assalto a cidade através da industrialização em que a produção em massa, portanto, para o consumo massificado, adquiriu grandes dimensões. Não somente produziu o consumo de materiais, mas a produção de hábitos que somente se realizariam na cidade e por meio da vida urbana. Essa industrialização também faz nascer a sociedade urbana, ou seja, a sociedade que deriva dessas condições de reprodução redefinindo as relações sociais (urbanas e fundadas no valor de troca e que realiza a forma-mercadoria). Em pouco mais de 80 anos a atividade

${ }^{33}$ Grillo, 1997, p.54. 
industrial foi aos poucos transformando a vida urbana ao padronizar os costumes e permitir, cada vez mais, o adensamento populacional. Em pouco mais de 80 anos a cidade explodiu, tornou-se metrópole e seu Centro (adensando, concentrado e acentuado pelos conteúdos deste processo) tornou-se o espaço implodido (figura 01) que, ao mesmo tempo, foi também gerador de uma nova contradição, entre abundância e raridade do espaço.

O Centro era até a década de 1970 o espaço portador de uma centralidade econômica, comercial e também simbólica, cujo metro quadrado mais valorizado era geralmente o que estava no sentido sudoeste, subindo a colina em direção a Avenida Paulista, exatamente na porção onde, anteriormente, tanto a elite cafeeira quanto a classe média e média alta ocuparam. Tanto a valorização quanto a centralidade, como também o próprio Centro (Sé e República), nesses casos, estão visivelmente atrelados ao caráter classista da ocupação do espaço. Fragmentação e hierarquização, quando se tornam processos que derivam (e ao mesmo tempo influenciam) a produção e o consumo do espaço, tornam-se também processos que apontam as tendências que estão postas para a valorização diferenciada dos lugares. Geralmente os espaços ondem residem a burguesia e/ou a pequeno-burguesia são aqueles em que, provavelmente, haverá maior valorização.

A realidade inerente à transição dos séculos marcou as condições para o estabelecimento da atividade industrial, com as regras do capital que ainda não operavam. Contudo, foram alguns fatores importantes, inerentes ao movimento histórico de transição, que devem ser considerados até a consolidação da forma capitalista da atividade industrial que transformou significativamente a cidade, implodindo-a em seus conteúdos de urbanização e transformando-a em metrópole.

Até a década de 1970, o Centro de São Paulo (especialmente os distritos Sé e República) concentrou o poder econômico e político, conferindo-o também como um centro de decisões. Praticamente todos os elementos constituidores ${ }^{34}$ da sociedade capitalista que estavam encravados no Centro de São Paulo até este período conferiam ao lugar seu caráter de rarefeito, superedificado, superadensado, superocupado, conferindo a raridade de seu espaço. No Centro, o consumo do lugar significou a sua ocupação com taxas elevadíssimas devido a tudo que este espaço oferecia. Toda infraestrutura materializada historicamente nos lugares, a facilidade para realizar deslocamentos e a facilidade de acesso (afinal, o Centro é também o

\footnotetext{
${ }^{34}$ Estado, escritório das grandes empresas, centro financeiro, equipamentos culturais e de lazer, adensamento populacional, adensamento construtivo, escolas, universidades, centro de formação, espaços de consumo, centros de compra, a classe média, partes do entorno próximo de bairros burgueses, e a maior parte dos arredores ocupados pelo proletariado etc.
} 
nó dos transportes públicos em São Paulo) caracterizou, ao longo do tempo, sua ocupação intensiva e verticalizada.

A industrialização, da mesma forma que explodiu continuamente o tecido urbano da metrópole, acentuou, concentrou e implodiu seu Centro que passou a ter naquele momento novos significados para a realização das atividades econômicas, ao mesmo tempo em que as mesmas condições permitiram a especulação imobiliária do espaço. O espaço, implodido e superedificado chega ao ápice de sua valorização em função da quantia significativa de trabalho acumulado (capital mobilizado no espaço) fazendo das determinadas configurações espaciais as próprias condições para a realização da atividade produtiva.

O Centro de São Paulo apresentou, enquanto característica da produção de seu espaço, o excesso de verticalização ao mesmo tempo em que houve o excesso também de expansão da sua periferia, principalmente na direção leste e sul, onde estas eram possíveis. Nesse momento em que o Centro foi completamente implodido, a dimensão econômica que determinou o processo se sobrepôs à dimensão social (aqui compreendida como aquela ligada às formas de moradia e residências, da afirmação da cultura e do passado em suas formas arquitetônicas etc.). A dimensão econômica também significou sua valorização nos termos da acumulação, afinal, onde o espaço se tornou raro o preço do $\mathrm{m}^{2}$ adquiriu valores significativamente elevados.

A metrópole, então caracterizada pela sociedade dos excessos de produtos industriais e pelos novos conteúdos do processo de urbanização, ao explodir em extensão sua periferia, implodia também o próprio Centro, então concentrado e adensado. Assim, enquanto a industrialização produzia novas abundâncias até então nunca vistas, ela produziu também uma sociedade de consumo dirigido ${ }^{35}$ que, contraditoriamente, no Centro, resultou no seu inverso através da raridade do espaço.

A raridade que produziu a excessiva valorização (conforme podemos observar nos trechos em destaque da citação anterior), produziu também a especulação, ao mesmo tempo em que a reprodução das relações que compõem a totalidade das produções, exigiu novos espaços. O Centro, implodido, já não comportava mais as novas necessidades espaciais de realização do capitalismo e, assim, o que houve foi um processo de desdobramento do Centro metropolitano, para o mesmo sentido em que haviam ocupado as elites que décadas anteriores "fugiram" do Centro popularizado. Para o Centro tradicional (composto pelos distritos Sé e

\footnotetext{
${ }^{35}$ Levando em conta a especificidade das relações sociais pautadas pela realização do consumo. Este, por sua vez, se intensificava progressivamente, conforme os ritmos da vida urbana.
} 
República) o resultado, ao longo da década de 1980 em diante foi um processo de desvalorização, que aproximadamente após 20 anos iniciaria seu processo de revalorização.

\subsection{DO INDUSTRIAL AO FINANCEIRO (E/OU TERCIÁRIO AVANÇADO): AS METAMORFOSES DO CENTRO NO ESPAÇO-TEMPO DA METRÓPOLE}

A reprodução da metrópole, caracterizada na produção de novos sub-centros, promoveu o deslocamento espacial das novas atividades econômicas e a acentuação ainda maior da população com maior poder aquisitivo nestes novos lugares que estavam na direção deste movimento, com predomínio para o vetor sudoeste.

As redefinições do processo produtivo, no que tange ao movimento que vai da indústria de transformação para o predomínio do setor de serviços (e/ou terciário avançado), imprimiram à metrópole redefinições também em seu espaço. Consequentemente, tais redefinições impactaram diretamente no Centro de São Paulo em função da diminuição da densidade de sua ocupação, pois, para além da saída das elites, houve também, pós-1970, um processo diminuição dos escritórios de serviços e do setor financeiro. O Centro implodido (concentrado e adensado em todos os sentidos), não comportava mais as exigências que apontavam na metrópole as transformações já decorrentes de seu processo de reprodução. Conforme foram surgindo os novos sub-centros no sentido do vetor sudoeste, a centralidade econômica também foi adquirindo novas formas e, consequentemente, projetando um eixo neste vetor. A necessidade de novos espaços para comportar as novas atividades produtivas (ou atividades de gestão da produção), ocorreu em função da possibilidade de produzir nesses lugares as infraestruturas e equipamentos, devido à existência de espaço. $\mathrm{O}$ resultado foi a expansão das atividades de serviços modernos para o sentido sudoeste, que, consequentemente, além de suprir a demanda que se constituía, possibilitou também a constituição de um polo de atração de investimentos imobiliários ${ }^{36}$. A nova morfologia urbana, caracterizada nos edifícios de alto padrão (que permitiram a aplicação das novas tecnologias de informação e comunicação), ao se consolidar, ocupou uma área que Carlos (2004) caracterizou como "eixo empresarial", que permitiu, ao longo do tempo, o processo de adensamento e verticalização predominantemente voltado aos edifícios de escritórios e hotéis ${ }^{37}$.

\footnotetext{
${ }^{36}$ Carlos,2004, p.66.

${ }^{37}$ Ibidem.
} 
O "eixo empresarial" no vetor sudoeste da cidade de São Paulo, conforme explicitou Carlos (2004), revela a centralidade econômica que derivou das necessidades de expansão intrínsecas ao próprio movimento de reprodução da metrópole, quando este passa a se desvencilhar das produções industriais que exigem menor mobilização de tecnologias para predominar as atividades ligadas ao setor financeiro como também do setor terciário de serviços avançados. Além de estar na direção de um vetor de valorização que se constituía cada vez mais, neste mesmo sentido sudoeste havia também espaços disponíveis decorrentes do processo de saída de grandes indústrias da metrópole para outros espaços.

Lencioni (1994) nos auxilia nesta compreensão quando expõe que a política de descentralização industrial (que, segundo a autora, abrangeu um raio de $150 \mathrm{~km}$ naquele momento) fez com que ocorresse na capital a concentração e o reforço das atividades de decisão e controle do processo de valorização do capital, conforme estes estabelecimentos se dispersaram. Entretanto, ressaltando o fato que a autora explicitou (e que destacamos linhas acima), a descentralização apenas ocorreu no âmbito das políticas, pois, no que tange ao entendimento da metrópole como a "capital da informação e da gestão", esta "se desconcentra como negação dos mecanismos de concentração e afirma sua centralidade" (LENCIONI, 1994, p.59). A desconcentração da indústria de transformação na cidade de São Paulo, enquanto um processo que se realizou a partir de uma ordem distante, levou à centralização tanto do capital financeiro quanto de setores ligados à sua operacionalização, como houve também a centralização de serviços do setor terciário avançado (também ligados à informática e telecomunicações).

O movimento que vai do capital industrial ao capital financeiro revela algumas transformações que são necessárias compreendê-las a partir de uma escala maior (mundial), que se realiza no lugar em função do processo de intermediação da metrópole e que, consequentemente, influencia diretamente no processo de reprodução do seu espaço. Assim, a reprodução capitalista da metrópole revela uma mobilização frenética do espaço ${ }^{38} \mathrm{em}$ que novos subcentros especializados são criados, transformando usos e funções do espaço, localizando estes usos e funções no plano do consumo do próprio espaço. A raridade do espaço no centro trouxe a valorização de outros lugares cuja centralidade se deu com um espaço produzido voltado à realização destes novos negócios. Em São Paulo, o vetor sudoeste exemplifica bem essa dinâmica da valorização dos lugares. Porém, vale salientar que a valorização de alguns lugares desencadeou um processo de desvalorização do Centro.

\footnotetext{
${ }^{38}$ Carlos, 2004.
} 
Figura 2 - Distritos do Centro Tradicional (Sé e República) e faixa de distritos que compõem o "vetor sudoeste"

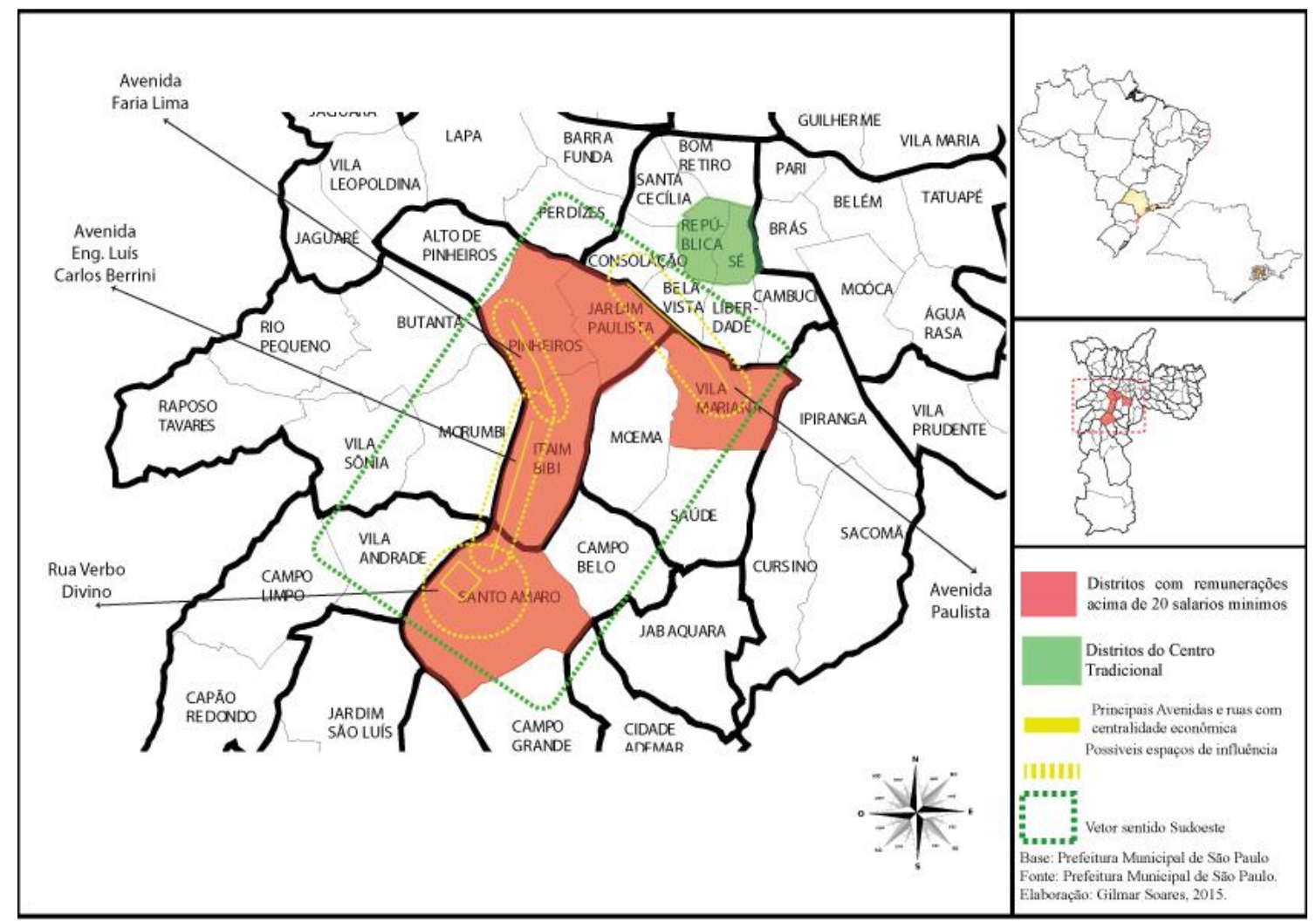

O movimento de expansão da centralidade econômica do Centro de São Paulo que, em meio a explosão da metrópole e sua ininterrupta reprodução, ao longo do tempo foi do Centro de São Paulo até as margens do rio Pinheiros no setor sudoeste, também não ocorre de maneira aleatória. Tanto a disposição das classes sociais no espaço quanto os distritos da capital onde se pagam os maiores salários, apresentam características ligadas ao que podemos considerar como dinheiro circulante (e/ou acumulado no lugar), que são fatores preponderantes que podem ser relacionados com este movimento, ao mesmo tempo em que coadunam com a expansão para este vetor sudoeste de São Paulo.

De fato, há um deslocamento das atividades econômicas que mobilizaram remunerações e salários mais elevados para o vetor sudoeste, contudo, convém ressaltar que no Centro de São Paulo (e mais especificamente nos distritos Sé e República) ainda o pagamento de salários elevados nos auxilia na compreensão de que ainda é significativa as atividades econômicas nestes distritos. Sobre essa transformação que imputa uma centralidade econômica para outros lugares da metrópole, Cordeiro (1980, p.70) assimilou a setorização enquanto três tipos de subsetores: 1) subsetor de assimilação: ligado ao terciário moderno e que exigem nova morfologia e disposição espacial para a realização dessas atividades; 2) 
subsetor de degradação: qual destacou o oferecimento dos serviços menos sofisticados; e, 3) subsetor de transição de remanejamento: com relativa estagnação em que há relativa retenção no processo de expansão. Observa-se que já nestes estudos da autora a relação entre as metamorfoses do Centro de São Paulo já podem ser compreendidas em função do critério de classes sociais, afinal, as áreas onde o Centro se encontra estagnado (conforme a exposição da autora) são aquelas em que as atividades mais populares se realizam e onde estão também os menores rendimentos. Ocorreu que a partir da década de 1970, os estabelecimentos comerciais ligados a este subsetor de assimilação ${ }^{39}$, principalmente os ligados aos setores de serviços avançados, setores financeiros e sedes de empresas, começam a deixar o Centro de São Paulo. Carlos (2001, p.141) apresenta uma consideração interessante sobre este movimento de centralidade que preenche um eixo sentido sudoeste da metrópole:

Se o Centro apresenta, hoje, o maior número de edifícios de escritórios da metrópole, a saturação de sua área, tanto para a renovação quanto para a construção de novos edifícios, é um dado importante, que alavanca a ocupação dessas novas áreas. Com isso, a região do Centro vai apresentando tendência à perda de participação em detrimento de novas áreas. Foi antecipada essa perspectiva nos anos 70, quando a atividade foi "subindo o espigão" ocupando o bairro da Bela Vista até a Consolação, em direção à Avenida Paulista, onde se construiu o segundo polo mais importante da cidade. Se no início esse movimento de deslocamento de escritórios se deu na ocupação da Avenida Paulista, esta, pelos altos preços do metro quadrado, impôs a "busca" de outras áreas. Antecipando-se a esse processo, na segunda metade dos anos 70 iniciou-se a ocupação da Avenida Luís Carlos Berrini por meio de vários empreendimentos imobiliários realizados por Bratke e Collet, em decorrência do desenvolvimento de obras viárias importantes. A ocupação da região sudeste nas décadas posteriores - principalmente nos anos 90 - apresentou características diferenciadas e complementares à região central em relação ao tamanho, ao tipo de imóvel e ao que se chama "qualidade de espaço" que diferenciaram os ocupantes e as atividades dentro do setor de serviços.

A transição, que vai do predomínio do capital industrial para o capital financeiro na metrópole, caracterizou para o Centro de São Paulo o movimento também de sua desvalorização. Conforme houve o deslocamento das elites, das atividades mais rentáveis, das sedes de empresas, das sedes dos bancos etc. para o vetor sudoeste, houve também nesta

\footnotetext{
${ }^{39}$ Para (CORDEIRO, 1980, p.70), o subsetor de assimilação é essencialmente de crescimento, em geral recente, recebendo novas atividades dos setores terciários e quaternários, que buscam um padrão de prestígio ao nível metropolitano por meio das lojas de artigos de luxo, sede de empresas, clínicas de profissionais liberais, serviços do setor quaternário, agências bancárias com novos padrões de atendimento, lojas de autopeças que vendem sofisticação etc.
} 
direção um processo de valorização do espaço. Nesse caso, evidente que não estamos considerando apenas os casos em que há maiores remunerações salariais. Nestes mesmos distritos estão também os maiores preços de metro quadrado do solo da metrópole, os maiores índices de salários por residências; o que implicou diretamente no Centro de São Paulo que, no momento anterior, se constituiu enquanto espaço mais valorizado (ou de maior valorização) da metrópole. O deslocamento da valorização apontou também o deslocamento da centralidade, a afirmação de novas representações do espaço e a diminuição de outras. A alteração nas representações do Centro transformaram significativamente os conteúdos deste lugar, comparado com outros lugares da metrópole que passavam então pelo processo de valorização. A consequência deste movimento foi o desencadeamento de um processo de desvalorização que passou a caracterizar o Centro de São Paulo.

Fica evidente que as metamorfoses que caracterizam tanto a paisagem quanto os lugares no Centro, nos termos de sua desvalorização ${ }^{40}$, derivam deste processo de expansão da centralidade econômica na metrópole. Assim, atualmente o processo de revalorização do Centro não pode ser compreendido no distanciamento deste que pode ser considerado o movimento reprodutivo da metrópole. Aliás, o processo de revalorização somente se realiza enquanto uma particularidade do processo de reprodução capitalista da metrópole, cujo fundamento de realização se ampara na propriedade privada das parcelas superedificadas do espaço no Centro de São Paulo. O movimento constitutivo de reprodução da metrópole, em função das dinâmicas do capitalismo no Brasil ${ }^{41}$, atrelado ao próprio movimento histórico de produção do espaço da metrópole - que produziu o Centro superedificado, adensado e concentrado (implodido) - produziu também uma contradição do espaço ${ }^{42}$ que pode ser considerada como um caminho significativo para compreender as intervenções no Centro de São Paulo na atualidade. Isso significa que o movimento de revalorização surge como negativo da desvalorização e aponta enquanto especificidade a relação próxima entre as estratégias do setor imobiliário (entre construtoras e incorporadoras etc.) e a Prefeitura Municipal de São Paulo.

\footnotetext{
${ }^{40}$ Nesse caso, é importante frisar que, diferente de outros lugares da metrópole, o Centro foi o espaço historicamente produzido pela elite cafeeira para ser portador de uma centralidade que se realizasse em todos os âmbitos, a ponto de mantê-lo no topo da hierarquia dos lugares da metrópole.

${ }^{41}$ Momento inicial de surgimento da atividade industrial para fomentar o processo de urbanização que se iniciava; posteriormente, a industrialização que explodiu a metrópole; em seguida a desconcentração da atividade industrial para outras cidades e Estados brasileiros, ao mesmo tempo em que a metrópole coordena, praticamente, todo processo produtivo tanto na cidade quanto no campo. Além do mais, ao centralizar quantias significativas de capital para realizar estas atividades de "gestão" econômica do território brasileiro (o que não implica, necessariamente, no predomínio de uma gestão política).

${ }^{42}$ Lefebvre, 2000.
} 
A reprodução do Centro de São Paulo aponta sua realização conforme o processo que ocorre (e/ou ocorreu) em escala global. Os "modelos" de revalorização dos Centros das metrópoles ao redor do mundo também passaram à ordem do dia na cidade de São Paulo sob a influência da iniciativa privada e entidades de classe burguesa (Associação Viva o Centro). Alguns álibis, como o da cultura e o da violência, norteiam às intervenções, como também as ações do Estado em parceria com a iniciativa privada, e, até mesmo, a indústria do imobiliário. Revalorizar o Centro de São Paulo é, aos poucos, atribuir a estes lugares novos valores de uso, para que os mesmos possam ser vendidos a preços de mercado mais elevados, dando continuidade ao processo de acumulação.

\subsection{DesvalorizaÇão e ReValorizaÇão do Centro: a eSCASSEZ do eSPaÇo e AS lutaS de Classes como lutas Pelo Centro de São Paulo}

O ápice da valorização do Centro de São Paulo foi também o ponto de transição para seu processo de desvalorização, afinal, a sua saturação foi o que impediu a expansão do setor de serviços na área central ${ }^{43}$. Atualmente, a desvalorização do Centro de São Paulo é fundamentada através das formas arquitetônicas deterioradas bem como pela expressiva parcela da população pobre que se encontra na área central. Fundamentada nos conteúdos da paisagem e do lugar, a desvalorização ocorre em concomitância com o processo de revalorização do espaço.

A respeito do processo de desvalorização, vale salientar que outra especificidade dialética pode ser compreendida na relação da valorização de outros lugares da metrópole, levando em conta tanto os padrões de infraestrutura (nesse caso, tudo que constitui-se como um suporte para a realização das novas atividades econômicas) quanto os padrões arquitetônicos dos novos edifícios, praticamente todos adaptados a estas condições.

A revalorização traz em primeiro plano a volta da moradia no Centro, contudo, não significa que este seja um convite voltado às moradias populares (apesar de alguns projetos estarem postos nesta ordem). A dimensão da habitação é, portanto, uma das dimensões que compõe o quadro de estratégias para a revalorização do Centro de São Paulo; além desta (especificamente assentada na acumulação pelo mercado imobiliário), há também a dimensão da cultura que, além de contribuir na afirmação da anterior, incentiva também o consumo do espaço através da atividade turística. No Centro, museus, teatros, bares, casas noturnas, casas de shows, casas de espetáculo, a sala de concerto, mercado municipal, Rua 25 de março, Rua

\footnotetext{
${ }^{43}$ Carlos, 2011, p.113.
} 
Santa Ifigênia, entre outros, compõem o rol de atrativos que possibilitam realizar neste fragmento da metrópole um polo ${ }^{44}$ (envolvendo os atrativos e hotéis) que gire e funcione em torno da cultura e consumo do espaço.

A desvalorização do Centro, todavia, é atribuída a sua ocupação popular, afinal, conforme houve a reprodução capitalista da metrópole ${ }^{45}$, houve também o aumento da ocupação do Centro pelas classes mais populares. Contudo, nem todo o espaço do Centro (e ainda mais do seu entorno) foi predominantemente ocupado pelas elites. No Centro de São Paulo, os lugares mais próximos às várzeas dos rios (Tamanduateí e Tietê) foram, desde que o Centro passou a ser um espaço transformado pela elite cafeeira, espaços ocupados pelo proletariado paulistano, migrante ou não. O Centro também foi (e ainda é) caracterizado pelos cortiços e pelas moradias operárias nas suas proximidades.

Conforme houve o esvaziamento dos edifícios comerciais de serviços mais avançados e a saída das classes média e média alta do Centro, houve, por conseguinte, a acentuação da sua ocupação proletária.

A revalorização do Centro representa, também, a restituição da centralidade até então diminuída, explodida para outros lugares da metrópole (como foi o caso de algumas instituições do governo que passaram a se localizar na Avenida Paulista). Porém, quando consideradas a volta destas instituições de poder para o Centro de São Paulo, o movimento

\footnotetext{
${ }^{44}$ Cf. p. 227.

45 A noção de reprodução capitalista da metrópole pode ser compreendida também quando o processo de urbanização (portanto, aquele que somente ganha forma no seu ir-sendo e que constitui o movimento que também realiza a forma-urbana) se realiza diretamente relacionado com o comércio e/ou relações de compra e venda, ou seja, sob os conteúdos que fomentam a realização do valor de troca. Neste movimento, o modo capitalista de produção fomenta a produção do espaço urbano também enquanto forma, neste caso, historicamente e socialmente produzido, da mesma maneira que este se converte também em forma-mercadoria. Ao se tornar uma condição que somente lhe é atribuída numa produção em que tudo tende potencialmente à produção capitalista, o espaço urbano atribuído à forma-mercadoria se realiza também enquanto um produto que é levado ao mercado, para que o valor de troca que fundamenta esta forma se realize através da comercialização fomentada pelo novo valor de uso produzido. Marx $(2011$, p.533) assevera que do ponto de vista material a mercadoria permanece capital desde que consista em matéria-prima, portanto, instrumento e meio para que o processo de trabalho possa transformá-la. Levando em conta este movimento de pensamento, há uma relação intrínseca entre a materialidade do espaço e a forma-mercadoria, já que, nesta condição de materialidade, o espaço permanece capital porque se torna, por sua vez, um instrumento (portanto, um meio) para que o trabalho vivo possa, constantemente e/ou de tempos em tempos, bem como das mais diversas formas, conferir-lhe o novo valor. A materialidade histórico-social do espaço, ao torná-lo um meio para a realização do processo de valorização do valor, torna-o também uma forma que se realiza enquanto potência para a reprodução do capital. Por este meio, o processo de urbanização torna-se também - ainda mais nas condições atuais - um metabolismo necessário para a reprodução do capital. Por meio da reprodução capitalista da metrópole, levando em conta um processo de valorização diferenciada dos lugares, a produção do espaço urbano e todos os processos que nele estão envolvidos, também coincidem com o atual estágio produtivo da metrópole, tanto na reprodução de suas formas quanto na adequação dos espaços que permitam o desenvolvimento das suas atividades produtivas.
} 
aponta para a manutenção de uma lógica que separa e ao mesmo tempo fundamenta a separação das classes no espaço ${ }^{46}$.

No Centro de São Paulo, as contradições do espaço revelam através das estratégias (tanto do capital quanto do Estado, na efetivação das políticas urbano-territoriais) os conflitos de classes que emergem neste movimento de descontinuidade de espaço e tempo da reprodução do espaço. A descontinuidade entre valorização e desvalorização, revela uma relação espaço-temporal da reprodução do espaço que, no Centro de São Paulo, reproduze as relações entre classes sociais em um patamar superior àqueles que se realizam no campo da produção material. As políticas de intervenção na atualidade revelam o espaço tornado abstrato, imediato à prática ideológica assentada nos pressupostos da revitalização, requalificação, reurbanização etc. Ao mesmo tempo, tais políticas ainda servem de subsídio inexorável à realização do capital, dando continuidade aos processos anteriores que são realizados pelas formas de fragmentação. Ou seja, ao mesmo tempo em que há descontinuidades, há também continuidades que ainda se realizam como forma de manter (e/ou mesmo acentuar) as segregações que ocorrem no espaço, fragmentando, hierarquizando e separando as classes sociais no espaço.

O movimento histórico que produziu a valorização do Centro de São Paulo é o próprio movimento constitutivo da metrópole, seja da expansão da sua morfologia espacial, ou seja, da expansão da sua morfologia social. Contudo, a desvalorização do Centro revela a descontinuidade de um processo, de um momento histórico para lançar a metrópole a outro momento e a novas formas de relações que ainda se realizam. Assim, tempo e espaço tornamse expressivos e significativos no que tange a realização do valor através da produção do espaço urbano. Se houve um processo de valorização e, posteriormente, de desvalorização do Centro de São Paulo (bem como de qualquer outro fragmento da metrópole), isso somente se torna inteligível quando tal processo é concebido em relação com a totalidade. A produção do espaço urbano para o processo de realização do valor consiste, portanto, na produção de m novo valor de uso para o espaço, conforme as necessidades que também estão atualmente produzidas; ao mesmo tempo, a produção do espaço é também a produção de uma mercadoria em suas condições e conteúdos de consumo, cujo valor capitalista ganha seu fundamento no processo de troca. Assim, a reprodução de um novo espaço com as condições mais atualizadas permitem a continuidade da reprodução das relações de produção na metrópole, como

\footnotetext{
${ }^{46}$ Essas mesmas instituições de governo, quando localizadas em algum lugar, tendem também a fazer parte do processo que o valoriza. Assim, a volta de algumas instituições do Estado ao Centro de São Paulo também caracterizou o estabelecimento das representações do espaço de poder e dominação que, a nosso ver, vão de encontro com as estruturas e superestruturas que fixadas no espaço atribuem-no novas representações.
} 
também revela os conteúdos que permitem a valorização do valor. Dessa maneira, a partir do momento em que um espaço para por um processo de valorização (e no caso do Centro, um processo de revalorização), implica que, ao mesmo tempo, outros espaços passam pelo processo em que não há a realização do valor de troca o que, consequentemente, concatena em um processo de desvalorização.

A desvalorização do Centro revela também uma ruptura e a exigência de um movimento de expansão da centralidade pelo fato de revelar uma dialética que é própria da produção do espaço; enquanto processo negativo da própria saturação do Centro, a nova Centralidade (nesse caso, predominantemente econômica) exigiu novos espaços e, consequentemente, imputou a valorização de novos lugares da metrópole. A descontinuidade entre valorização e desvalorização do Centro revela-se na sua própria contradição de escassez de espaço através da impossibilidade de continuar a se reproduzir com novas exigências. Contudo, se valorização e desvalorização apresentam descontinuidades, a própria revalorização também comporta os traços desta descontinuidade e exige nos elementos e/ou fatores que os novos valores coadunem com sua reprodução.

A reprodução do Centro se realiza através de elementos históricos que são apropriados para comporem a representação do espaço. Nesse caso, a cultura desempenha uma função primordial que também entra na produção dessas representações. Ao desempenhar esta função, a dimensão cultural passa por uma redução brutal de todo seu significado histórico. Ao se tornar o fator principal para reverter o processo de desvalorização através da afirmação de uma identidade para o Centro de São Paulo, a cultura (através de seus conteúdos) passa por um movimento que vai do álibi, portanto, uma justificativa, para se transformar no próprio negócio. Se com a desvalorização houve um processo de acentuação da ocupação proletária do Centro de São Paulo, com o processo de revalorização e a cultura transformada em negócio, há uma ampliação dos conjuntos articulados de elementos que coloniza a relação entre capital, reprodução do Centro de São Paulo e cultura.

Com a desvalorização, o processo de apropriação proletária do Centro de São Paulo, enquanto forma de luta organizada, inicia-se na metade da década de 1970 e tem o auxílio das Pastorais da Arquidiocese de São Paulo com a população moradora dos $\operatorname{cortiços~}^{47}$, de forma que em 1985, além dos cortiços, a população em situação de rua, os catadores de materiais recicláveis, os ambulantes e as crianças ${ }^{48}$. A década de 1990 marcou o inicio da organização política, de fato, em torno da luta pelo Centro de São Paulo com a constituição dos

\footnotetext{
${ }^{47}$ Silva, Silva, Kroll, 2008.

${ }^{48}$ Ibidem.
} 
movimentos sociais, iniciando com o Movimento Unificado Dos Cortiços (MUC). Nesse período surgia também o Movimento dos Sem Teto do Centro (MSTC), o Movimento de Moradia do Centro (MMC) ${ }^{49}$. Entre os anos de 1997 e 2000 ocorreram as primeiras ocupações do Centro de São Paulo ${ }^{50}$, e alguns distritos do entorno.

Figura 3 - Ocupações realizadas entre 1997 e 2005

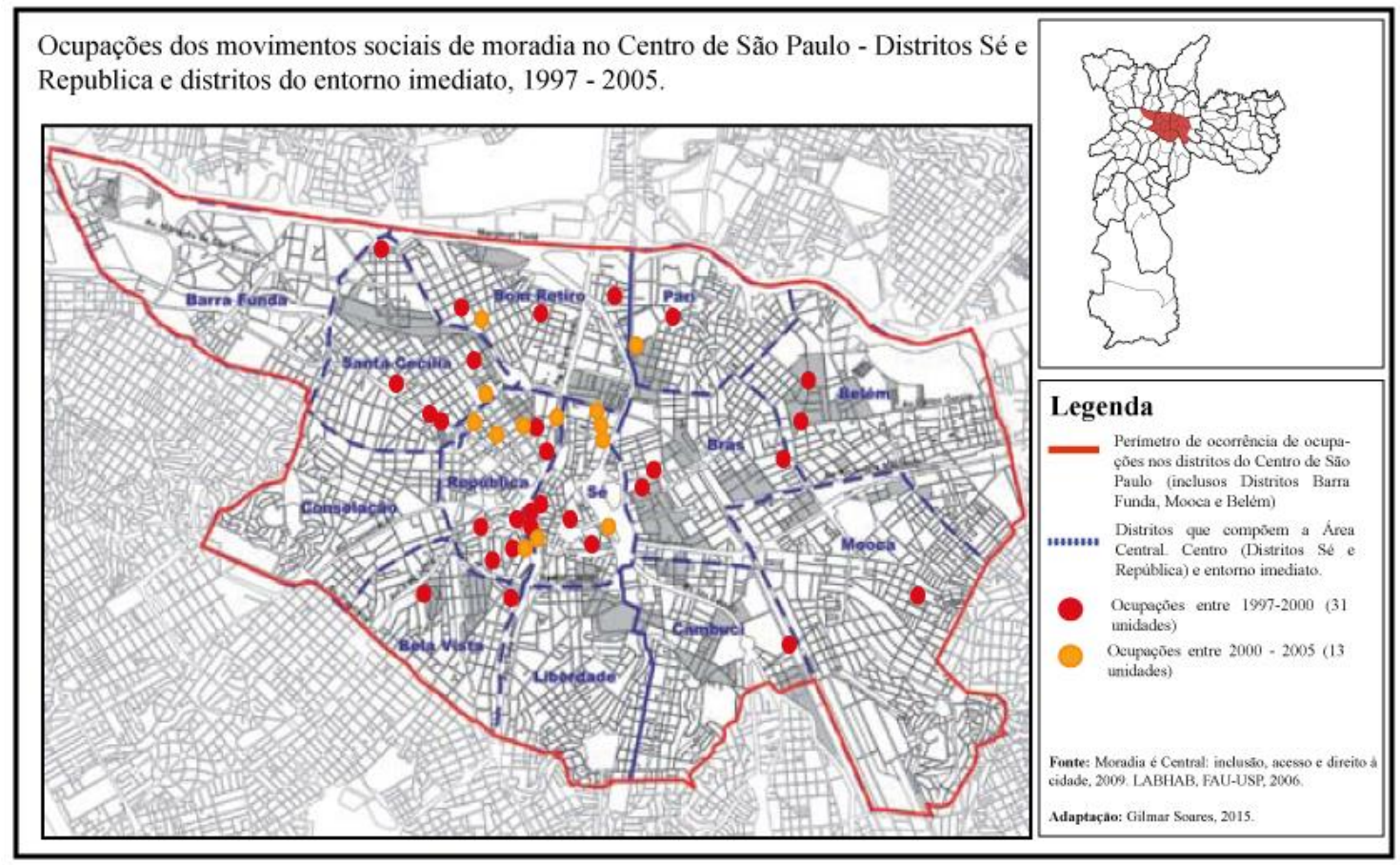

Se a dimensão das ocupações revela o plano social em que surgem as resistências e suas práticas, neste plano social há também o resultado das políticas do Estado para a revalorização do Centro que surte de imediato nos resultados sobre a vida cotidiana e aponta os pontos de tensão que se realizam através das disputas que ocorrem no (e pelo) lugar. A política da PPP Casa Paulista foi alvo de resistência dos moradores dos lugares em que estavam planejadas desapropriações. Por meio de mobilização e (re)mapeamento dos espaços em que iriam ocorrer estas desapropriações, os moradores, entidades de classes e movimentos sociais se organizaram ${ }^{51}$ para a divulgação do decreto que, posteriormente, seria revogado.

\footnotetext{
${ }^{49}$ Ibidem, p.92.

${ }^{50}$ Ibidem, p. 93.

${ }^{51}$ Uma carta aberta foi emitida e assinada pelos seguintes movimentos e entidades de classe: Associação dos Moradores e Amigos da Sta Ifigênia e Luz - AMOALUZ; Associação Conde São Joaquim - ACJ; Central de Movimentos Populares - CMP; Centro Gaspar Garcia de Direitos Humanos - CGGDH; Conselho Gestor ZEIS 3 C 016 -Sé - Representantes da Moradia; Defensoria Pública do Estado de São Paulo- Núcleo de Habitação e Urbanismo Frente de Luta por Moradia - FLM; Grupo de Articulação para Moradia do idoso da Capital GARMIC; Habitat Projeto e Implantação para o Desenvolvimento do Ambiente Habitado e Urbano- Brasil Habitat; Instituto Polis Laboratório Espaço Público e Direito à Cidade - LabCidadeFAU-USP; Laboratório de
} 
Nas práticas socioespaciais (em meio a esta realidade de lutas de classes) os interesses opostos entre classes sociais distintas ilumina as formas de resistências. A permanência de pessoas pertencentes ao proletariado que já ocupava o Centro de São Paulo, bem como os diversos processos de ocupação por parte dessa classe social, fez com que, do ponto de vista da disputa pelo espaço entre as classes, esta intensificação da proletarização caracterizasse o próprio processo de desvalorização. Dois pontos norteiam este conflito: 1) a figura destes sujeitos proletários que ocupam e residem no Centro de São Paulo; 2) a relação destes com o espaço, através dos conteúdos que compõem as diversidades de forma de apropriação que concatenam no valor de uso.

Conforme houve a saída das elites do Centro de São Paulo (até a década de 1970), houve, em contrapartida, a acentuação do processo de sua ocupação proletária, atrelada a própria condição de encortiçamento que já existia em momentos anteriores trazendo a desvalorização do espaço, o que caracterizou a intensificação do processo de proletarização do Centro.

O processo de revalorização na atualidade, carrega em seus conteúdos os traços e os planos que derivam do que estamos considerando como uma disputa classista pelo Centro de São Paulo. Sua reprodução, no início do século XXI, assumiu, de fato, os termos de interesses opostos pelo mesmo espaço. As transformações nos recortes territoriais para a delimitação da Subprefeitura Sé torna-se uma evidência significativa. Até o ano de 1991 a Administração Regional Sé era formada pelos 10 distritos que caracterizam o espaço predominante para as políticas no Centro de São Paulo. Segundo (PACCA, 2010, p. 210)

o motivo do desligamento desses dois distritos da Sé para a Zona Leste (Subprefeitura Mooca) ocorreu por pressão da Associação Viva o Centro, que entendia que essa configuração traria menos problemas para a administração do centro da cidade, onde ela possui trabalho ativo.

Assim, a Associação Viva o Centro criou e redefiniu algumas vezes seu território de atuação (figura 04), até chegar da definição atual. Certa de que as potencialidades de revalorização do espaço estão para além dos distritos Sé e República, a AVC constantemente assevera em suas publicações a relação entre a escassez de novos empreendimentos o processo de revalorização também se realizando nesta área do entorno.

Habitação e Assentamentos Humanos - LabHab FAU-USP; Movimento Apropriação da Luz; Movimento de Moradia Para Todos - MMPT; Movimento de Moradia da Região Centro - MMRC; Movimento de Moradia da Cidade de São Paulo - MMC; Serviço de Assessoria Jurídica Universitária da USP - SAJU; Unificação das Lutas de Cortiços - ULC; União dos Movimentos de Moradia - UMM. 
Figura 4 - Território de ação da Associação Viva o Centro

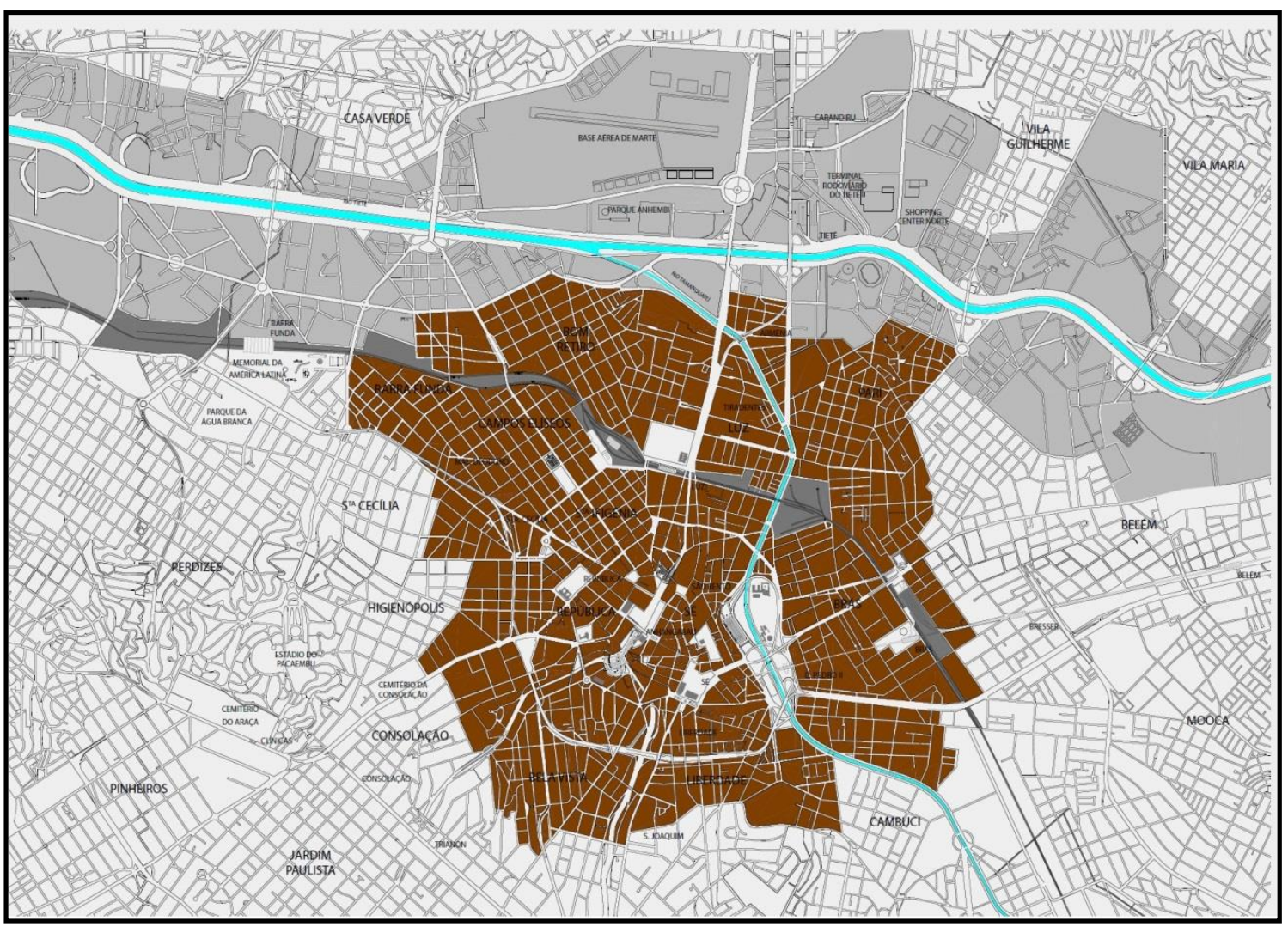

Fonte: São Paulo Centro: uma nova abordagem.

Associação Viva o Centro, Agosto 1996.

Adaptação e elaboração: Gilmar Soares, 2015.

De um lado uma Aliança Burguesa pelo Centro $^{52}$ e, do outro, uma massa proletária heterogênea, mais ou menos organizada em alguns casos, com diversas frentes que, todavia, se reconhecem quando são ameaçadas a deixar o lugar. O argumento da moradia no Centro também é apropriado pelas entidades que visam a revalorização do espaço. Observa-se nos discursos que um dos objetivos é reverter, aos poucos, este predomínio do perfil de morador proletário no Centro. Conforme um boletim da Associação Viva o Centro, a "moradia" também torna-se uma estratégia:

Trazer mais gente para morar no Centro funciona efetivamente como poderosa alavanca de requalificação urbana e melhoria social da área, e isso não é novidade em muitas cidades do mundo. A construção de algumas torres residenciais no Centro de São Paulo, nos últimos anos, e a perspectiva de expansão desse processo para áreas envoltórias do Centro Histórico, como Pari, Brás, Bom Retiro, é animadora e

\footnotetext{
${ }^{52}$ Mais do que a chamada "Aliança pelo Centro", criada pela Associação Viva o Centro (que nada mais é um conjunto de estruturas para receber as pessoas no Centro), essa Aliança Burguesa pelo Centro (que é visível nos membros da AVC) pode ser considerada como uma estratégia e união de classe para interesses mediatos e imediatos sobre o Centro de São Paulo.
} 
começa a concretizar essa que é uma das principais bandeiras da Associação Viva o Centro. O mercado imobiliário detecta aumento no interesse das pessoas em morar no Centro, para estarem perto do trabalho, de equipamentos culturais de alto nível e comércio diversificado. Detecta, ainda, a baixa oferta de moradia e começa a reagir. Morar no Centro voltou a ser bom e convidativo, e tudo indica que será ainda melhor.

A mudança do perfil do morador é latente nas estratégias para a revalorização do espaço, tanto que até mesmo as propagandas vinculadas aos novos empreendimentos imobiliários tem esta característica ${ }^{53}$. Mudar o perfil do morador do Centro de São Paulo é um processo que somente pode ocorrer aos poucos, pois tende a atrelar o lançamento de novos empreendimentos, a mudança do perfil arquitetônico, o estabelecimento de novas representações do espaço e as possibilidades, também, de reproduzir o capital por meio da reprodução do Centro. Alguns bairros do Centro ainda carregam consigo as representações do espaço "destruído", deteriorado (como é o caso do bairro dos Campos Elíseos, onde fíca a chamada cracolândia).

A desvalorização, expressiva na paisagem, também surte como uma estratégia de classe que tem na paisagem uma frente de negócios, pois, quanto mais miserável e inumano, mais baixo é o preço do metro quadrado, mais fácil torna-se a obtenção de novos terrenos. A paisagem como negócio ${ }^{54}$ também faz parte do processo de revalorização do Centro de São Paulo. Nela, ao mesmo tempo em que a miséria compõe o quadro do espaço deteriorado, essa serve de álibi para os discursos de requalificação visando novos moradores ${ }^{55}$, ainda mais após a intensificação do processo de sua ocupação proletária entre os meados da década de 1990 e 2000. Por conseguinte, estes novos moradores também gerariam uma demanda significativa de novos empreendimentos.

Raridade e abundância compõe o quadro atual da contradição que atravessa o Centro de São Paulo, e nela, a dimensão da luta de classes, enquanto luta pelo Centro de São Paulo, emerge algumas formas que caracterizam a problemática urbana na atualidade. Valorização, desvalorização e revalorização, evidenciam um processo de reprodução do espaço em que a valorização diferenciada dos lugares da metrópole contribui com um processo (de produção

\footnotetext{
53 Como é o caso do empreendimento "Newway Liberdade", lançado pela Brookfield, cuja uma das suas propagandas é: "Classe média de São Paulo volta a morar no Centro".

${ }_{54}$ Noção posta pelo colega Luís Soares em um dos seminários de orientação coletiva.

${ }^{55}$ Em entrevista à revista URBs n ${ }^{\circ} 50$, o então vereador do PSDB, José Police Neto asseverava que "Não é só a moradia popular que deve estar no centro expandido. É moradia. Não vamos errar o alvo. Tem que repovoar com todos aqueles interessados em vir para o Centro". E continuava: "No Centro, não é possível ficar só com política de cortiço e de baixa renda. É preciso construir para a classe alta, a classe média e, evidentemente, os mais pobres. Mas o mais importante não é revitalizar cortiço, e sim proporcionar dignidade na moradia".
} 
do espaço) em que a valorização do valor, "encarnada" na produção de um novo valor de uso para o espaço, por sua vez, se converta em um valor de troca e configure os conteúdos do espaço-mercadoria. Torna-se evidente que a própria configuração das classes sociais torna-se também um fator preponderante para a relação entre valor e espaço. No caso do Centro de São Paulo é a própria mudança dos sujeitos (e neste caso, suas identidades pautadas em suas classes sociais) que contribuem diretamente com o discurso da revalorização. Na reprodução da sociedade sob o modo capitalista de produção, bem como na reprodução das próprias relações que caracterizam esta forma de produção, a reprodução do espaço - neste caso configurada na própria reprodução da metrópole paulistana - torna-se, também, mais um meio para que a reprodução das classes sociais persista e ainda adquira novos conteúdos. No século XXI, cada vez mais a metrópole ganha centralidade, da mesma maneira que torna-se condição para que tanto as relações que produzem formas de acumulação, bem como a cisão entre as classes que são necessárias a estas formas de acumulação, ainda continuem. 


\section{CAPÍtulo II - A RARIDAde do ESPAÇO \\ O CENTRO DA METRÓPOLE SOB O CRIVO DA PROPRIEDADE PRIVADA DO SOLO URBANO}

O processo de revalorização do Centro de São Paulo revela em suas características atuais o resultado que deriva de um movimento histórico inerente ao processo de urbanização capitalista e à produção-reprodução da metrópole sob esta mesma lógica. A explosão da metrópole em função do processo de industrialização fez com que, ao longo do tempo, lugares fossem produzidos e reproduzidos, alguns passando por um intenso e significativo processo de valorização. O Centro de São Paulo é o fragmento da metrópole que expressa de maneira significativa esta dinâmica, afinal, conforme houve seu movimento de explosão da metrópole (com a implosão dos seus conteúdos, os conteúdos das periferias) houve também o movimento de valorização acentuada de alguns lugares, e, consequentemente, a desvalorização do Centro de São Paulo. Valorização e desvalorização do espaço constituemse enquanto um fenômeno (urbano, por sinal) que somente se realiza quando as condições inerentes ao desenvolvimento das forças produtivas (portanto, condições históricas) permitem com que o espaço socialmente produzido entre, também, no processo de produção enquanto uma forma produtiva que permite a realização de mecanismos de valorização do valor.

Levando em consideração este movimento que pode ser apreendido na história, a propriedade privada do solo urbano passa a ser a forma de propriedade burguesa que adquire centralidade, tanto no processo capitalista de urbanização quanto no movimento de reprodução do espaço que caracteriza tal processo na atualidade. Nesta relação, a propriedade privada do solo urbano torna-se o fundamento que, atrelado às condições que caracterizam o lugar, permitem a produção de um novo valor de uso para o espaço. A propriedade privada do espaço ganha centralidade neste processo em que os imóveis (entre estes, edifícios inteiros) permaneceram vazios, "aguardando" o momento certo de sua revalorização foram ocupados pelos "destituídos de moradia".

A transgressão à propriedade privada do espaço (por meio da prática de sujeitos que ocupam prédios inteiros vazios) caracteriza uma forma de uso que não realiza o valor de troca e positiva formas de apropriação do Centro. Espaço construído, portanto, socialmente produzido, a propriedade privada edificada no Centro de São Paulo revela os excessos que exigem a reversão do processo. Em meio a contradição entre abundância e raridade de espaço, o fenômeno da vacância imobiliária sinaliza a atualidade perversa do processo de urbanização. Concebida enquanto capital fixo que possibilita formas de acumulação, a 
propriedade privada do espaço vazio no Centro aguarda os resultados das políticas de intervenção para a revalorização. Assim, atravessada pelos interesses daqueles que veem a propriedade privada do espaço enquanto possibilidade de acumulação, como também pelos interesses daqueles que a ocupa para a manutenção da vida, a propriedade privada do espaço torna-se um "impasse" à realização do valor de troca e, por conseguinte, a da formamercadoria que entra novamente no circuito de troca de reprodução do capital. Cabe ao Estado reverter este "impasse" por meio das políticas estratégicas e da modificação das normas, bem como por meio de práticas atuais sob o uso de medidas militares (ainda relacionadas ao uso institucional da violência) que se torna, cada vez mais, um condicionante necessário à realização do processo de urbanização.

No Centro de São Paulo isso fica evidente, seja pela expropriação daqueles que estão em condição de ocupação, seja pela pilhagem daqueles que necessitam do espaço público para desenvolverem alguma atividade que gere renda ou mesmo capaz de manter a vida (como é o caso dos moradores em situação de rua).

\subsection{O FUNDAMENTO DA PROPRIEDADE PRIVADA DO SOLO NO MOVIMENTO DE RevalorizaÇão do Centro de São Paulo}

A revalorização do Centro de São Paulo enquanto processo capitalista de reprodução deste fragmento da metrópole é parte integrante de um processo maior em que a metrópole se reproduz enquanto condição de realização de negócios imobiliários. Nesse movimento, a cidade permite ser interpretada enquanto mercadoria, já que todo seu espaço é pulverizado em vendido em parcelas no mercado. $\mathrm{Na}$ atualidade em que o capital se realiza promovendo e produzindo o processo de urbanização, o espaço torna-se elemento fundamental para compreender a extensão da forma-mercadoria. Considerando este como um movimento de pensamento que une teoria e prática, fazemos o esforço de tecer algumas considerações sobre a produção do espaço apontando o papel da propriedade privada do solo urbano, bem como os traços desta relação no Centro de São Paulo.

Assim, a propriedade privada do solo urbano, enquanto fundamento do processo de produção capitalista do espaço, permite estender o valor de troca e seus imperativos, ao espaço, afirmando-o em sua condição de mercadoria. Enquanto dimensão econômica, esta não se realiza sem a contribuição efetiva do Estado que imprime ao processo de produção do espaço uma dimensão política. No Centro de São Paulo as práticas estatistas de intervenção, enquanto estratégias de delimitação do espaço, ocorrem, pelo menos, desde o final da década 
de 1980. Atualmente algumas políticas compõem o quadro estratégico de intervenção no Centro sendo que uma já encerrou suas atividades (PROCENTRO), outra está embargada (Concessão Urbanística Nova Luz), outra em estágio inicial de seleção de projetos (Arco do Tietê), outra em atividade (Operação Urbana Centro) e outra, também em estágio inicial de editais (PPP Casa Paulista), este último realizado pelo Estado de São Paulo e os demais pela Prefeitura Municipal. O Estado, por meio da realização das práticas políticas de intervenção no espaço (o que não se restringe apenas a estas políticas urbano-territoriais), sob o predomínio da razão técnica e abstrata, torna-se o responsável direto pela reprodução espacial.

O espaço, enquanto condição e meio para a reprodução da vida, revela, por meio das estruturas socialmente e historicamente produzidas, as formas de apropriação que escapam ao imperativo da forma-mercadoria e, por conseguinte, do valor de troca. Por mais que o movimento posto à lógica capitalista de produção do espaço seja o da cidade enquanto força produtiva e/ou enquanto capital fixo, à lógica inerente desta forma de sociabilidade, sempre cindida em classes sociais, acaba reverberando no espaço. Dessa forma, aquilo que estamos considerando como um "impasse" recai sobre a forma propriedade privada do solo urbano, afinal, somente esta forma de propriedade (enquanto característica do espaço socialmente e historicamente produzido) absorve significativamente o processo de revalorização (como é o caso do Centro de São Paulo), ou mesmo toda valorização, que passa a ser característica ao espaço enquanto produto a ser consumido.

Fundamento de manutenção e reprodução da vida, o espaço socialmente produzido da cidade, quando apropriado, torna-se um "impasse" para a realização da forma-mercadoria e do imperativo posto pelo valor de troca. Assim, é somente no momento do "impasse" que a PMSP "entra em cena" e, como uma instituição gestora por excelência, ao dominar e controlar a disputa classista pelo Centro de São Paulo, visa tendencialmente em suas estratégias reverter este quadro de "impasse", sempre favorecendo as classes que produzem e buscam consumir este espaço socialmente produzido.

A relação entre Estado e espaço ${ }^{56}$, revela na dimensão institucional a prática de gestão característica às lógicas corporativas e estratégias da empresa capitalista. A racionalidade que atravessa as práticas de gestão do Estado é a mesma que, cientificamente, foi produzida para as empresas, através de um conhecimento corporativo aprofundado. Resultando na valorização diferenciada dos lugares, as intervenções que são aprovadas pela Câmara Técnica de Legislação Urbanística (CLTU) geralmente derivam das relações que hierarquizam e

\footnotetext{
${ }^{56}$ Aprofundada nos mecanismos de reprodução e revalorização do Centro de São Paulo ao longo de todo capítulo II.
} 
fragmentam também o Estado em seus diversos aparelhos. Em São Paulo, a instituição responsável pelas intervenções no Centro de São Paulo é a SP-URBANISMO (empresa pública ligada às intervenções urbanas) que coordena e direciona o perfil das políticas urbanoterritoriais, assim como também as formas de intervenção.

Direta ou indiretamente, sob o crivo do Estado, a propriedade privada do solo urbano, o lugar e a própria cidade, neste contexto de acumulação metamorfoseiam-se capital fixo e, ao mesmo tempo, em força produtiva no processo de reprodução da metrópole. Este é o sentido que imprime ao Centro de São Paulo e seu entorno um espaço com tendência a uma nova fronteira de acumulação, afinal, as estruturas e os esforços do Estado são todos, praticamente, movidos para este sentido que visa o processo de revalorização do espaço.

\subsection{O FENÔMENO da VACÂNCIA IMOBILIÁRIA No CENTro de SÃo PAUlo}

Carlos (2013, p. 103) assevera que o desdobramento da reprodução do espaço urbano reverbera na produção da metrópole subordinada aos interesses do grande capital, fato que subsumi os modos de apropriação do espaço ao mundo da mercadoria e à propriedade privada. Ou seja, a continuidade do processo de urbanização se realiza no movimento da reprodução do espaço em que a propriedade privada de um fragmento da metrópole (edificado ou não edificado, e mais ainda, aquele que se encontra no lugar superedificado) torna-se a condição para a produção capitalista deste espaço. Este movimento na atualidade somente se realiza pelo fato de que o espaço (socialmente produzido e portador de um conteúdo urbano) torna-se condição, meio e produto para a própria realização da vida na cidade e no urbano.

O Centro de São Paulo, assim como seus arredores imediatos, é portador de uma quantidade significativa de infraestrutura (conexões de modais de transporte ferroviário e rodoviário, concentração de comércio e serviços, postos de trabalho nestes setores, concentra algumas junções das vias de acesso mais importantes da cidade etc.), fato que diferencia este fragmento $^{57}$ dos demais lugares e fragmentos da metrópole. O Centro de São Paulo, em função da quantidade significativa de estruturas, infraestruturas e equipamentos urbanos que oferece, torna-se, ao mercado imobiliário, um lugar portador de possibilidades significativas de realização da acumulação. Nestes termos e por aquilo que ele oferece, tendencialmente, sua reprodução que o aponta enquanto uma nova fronteira de acumulação, aponta também a extensão do valor de troca ao seu espaço socialmente e historicamente produzido.

\footnotetext{
${ }^{57}$ Como também a diversidade de seus lugares.
} 
Esta extensão do valor de troca ao espaço resulta no movimento de um duplo processo: 1) a metrópole metamorfoseada em força produtiva; 2) a metrópole enquanto capital fixo. Ambos acentuando as condições atuais que põem o espaço e sua realização através da forma-mercadoria. Ao se tornar força produtiva e, ao mesmo tempo, capital fixo, a metrópole reúne as condições atuais para que a produção de seu espaço permita, a continuidade da reprodução do capital: fato que aufere ao seu espaço socialmente e historicamente produzido as possibilidades de extração do mais-valor deste processo produtivo ${ }^{58}$. Assim, sob as determinações da forma-mercadoria estendida ao espaço, o uso (e, consequentemente a apropriação) passa a ser submetido à troca (e ao valor de troca) e esta relação orienta no plano econômico os momentos de realização dos negócios imobiliários.

Ao investir na produção do espaço, o setor imobiliário revela-se enquanto potência que, cada vez mais, influencia diretamente os conteúdos da reprodução da metrópole através da primazia do valor de troca. Assim, conforme o processo de revalorização aponta as tendências para o Centro de São Paulo, os imóveis vazios explicitam a condição da propriedade privada do espaço na atualidade do processo de urbanização. A taxa de vacância, em meio a esta relação contraditória entre abundância e raridade do espaço, revela uma dimensão da problemática da produção do espaço que se realiza no âmbito do habitar e do habitat, concernente às relações privadas que atravessam as formas de acesso à cidade.

No que tange à reprodução do Centro de São Paulo o processo não se faz diferente, pois, enquanto um fragmento da metrópole dotado de quantidades significativas de trabalho acumulado (trabalho morto), o Centro de São Paulo evidencia também as condições atuais que fazem dele um capital fixo. Social e historicamente o Centro de São Paulo - enquanto um espaço dotado de qualidades - resulta de uma acumulação que, além de progressiva é também produtora de formas de excesso. Implodido, o Centro - e consequentemente seu entorno imediato a partir dos distritos vizinhos - passa pelo processo de sua própria reprodução, cujos conteúdos são balizados por um processo de revalorização que o torna também força produtiva.

Enquanto capital fixo o Centro torna-se o espaço em que o valor fixado caracteriza este acúmulo histórico de trabalho materializado. $O$ espaço portador de estruturas arquitetônicas e de infraestrutura específicas, também revela por meio destas a extensão do valor de troca e o movimento da forma-mercadoria. O espaço socialmente produzido do Centro, enquanto meio de produção, em seu momento de revalorização transfere também

\footnotetext{
58 A força de trabalho (trabalho vivo que atuará sobre o trabalho morto materializado neste fragmento da metrópole) permite a reprodução do valor excedente e parte constante do capital.
} 
valor ao produto, ao espaço reproduzido e consequentemente todos seus conteúdos. A revalorização do Centro de São Paulo é também o processo em que o trabalho vivo transfere valor ao trabalho morto que, além de materializado, também compõem o espaço. A reversão do processo de deterioração, nesse caso, se realiza através da adição de novos conteúdos ${ }^{59}$ ao espaço, redefinindo as concepções do Centro de São Paulo (como também do que é o Centro de São Paulo) em que o trabalho produtivo transforma e produz o espaço de maneira que o antigo valor - posto ideologicamente como desvalorizado - faz com que o Centro torne-se meio de produção para sua própria reprodução.

O uso, ao se realizar enquanto forma que não valoriza o valor, traz outra utilidade para o espaço no capitalismo que, do ponto de vista da acumulação, o torna um ativo em uso ${ }^{60}$, caracterizado por funções que não produz lucro. Segundo Bomfim $(2004$, p. 24) uma questão que envolve a vacância é o limite do prazo de término de execução do imóvel e seu abandono e, neste interim, manutenção e demanda não viabiliza mais os lucros e fazem com que os imóveis sejam abandonados ou locados como cortiços. Portanto, somente no capitalismo, conforme as necessidades de extensão da forma-mercadoria, o espaço adquire a forma do valor de troca. O capital fixado no espaço, conforme o período em que o valor não se valoriza, tende, por consequência, a "esperar" o momento exato da revalorização para que o investimento realizado surta o efeito esperado à realização do valor de troca. Este é o sentido que atribuímos ao fenômeno da vacância de imóveis no Centro de São Paulo. Esta realidade, por sua vez, somente ocorre no momento histórico em que o espaço também se realiza pela forma-mercadoria $^{61}$. O capital fixado no espaço, que por sua vez torna o espaço socialmente produzido do Centro de São Paulo como um capital fixo, para fins de superação da sua desvalorização, tende novamente a ser reproduzido de maneira a ser posto em circulação. A lógica do espaço socialmente produzido do Centro em função do seu processo atual de reprodução, através da revalorização de um espaço especifico, segue a mesma lógica qual (MARX, 2011, p. 518-519) assinala que

embora o capital, como totalidade da circulação, seja capital circulante, seja passagem de uma fase à outra, em cada fase ele também é posto em uma determinabilidade, confinado em uma figura particular que é a negação de si mesmo como o sujeito do movimento como um todo. Por conseguinte, em cada fase

\footnotetext{
59 Inerente a adição de um novo valor de uso, ou, nesse caso, por meio da produção capitalista do espaço, produzir um novo valor de uso a partir do valor que o próprio Centro de São Paulo ainda conserva.

${ }^{60}$ Neste caso não convém considerar aqui como inativo, afinal, diferente das outras mercadorias que são produzidas, o espaço tem sua especialidade quando torna-se condição, meio e produto para a realização da vida. ${ }^{61}$ Levando em conta as relações de produção e consumo, ainda mais considerando o ciclo que atravessa todo este movimento.
} 
particular o capital é a negação de si mesmo como sujeito das distintas transformações. Capital não circulante. Capital fixo, mais propriamente capital fixado em uma das distintas determinabilidades, fases que tem de percorrer. Enquanto persiste no processo de produção, não é capaz de circular; e [é] potencialmente desvalorizado. Enquanto persiste na circulação, não é capaz de produzir, de pôr mais-valor, de se processar como capital. Enquanto não pode ser lançado no mercado, é fixado como mercadoria. Enquanto não pode ser trocado pelas condições de produção, é fixado como dinheiro. Finalmente, se as condições de produção permanecem em sua forma como condições e não ingressam no processo de produção, o capital é outra vez fixado e desvalorizado.

Na situação de revalorização do espaço no Centro de São Paulo (principalmente nos distritos Sé e República em que o espaço encontra-se em condição de raridade), os imóveis vagos e/ou subutilizados consistem em estruturas arquitetônicas que implicam certa identidade ao espaço e, ao mesmo tempo, centralizam uma potência de realização do valor. No que tange ao primeiro caso, o fato de serem estruturas arquitetônicas que remetem à memória no período em que o Centro era valorizado, fazem com que estas contenham em si esta identidade que contem uma conotação histórica de um espaço de representação ${ }^{62}$. Se esta conotação histórica é o que potencializa a ressignificação do espaço, esta ressignificação, ao mesmo tempo, torna-se aquilo que potencializa a produção do espaço para a realização da forma-valor.

A partir do momento em que Centro de São Paulo é caracterizado por esta possibilidade, seu espaço historicamente e socialmente produzido contém em si as potencialidades da reprodução e, ao mesmo tempo, da volta do espaço aos circuitos de realização do capital. Contudo, por ser um espaço que socialmente - e isso do ponto de vista da totalidade da metrópole - contempla qualidades significativas para a realização da vida, o mesmo revela sua qualidade intrínseca relacionada ao valor de uso. $\mathrm{O}$ uso, nesse caso do espaço, quando balizado pela forma-valor revela também aquilo que se realiza sob os conteúdos que move as formas de consumo. Aliás, é o próprio ato de consumo do espaço que nos direciona para os determinantes da forma-valor e, neste caso, um ato de consumo que se realiza em conformidade com o próprio andamento da vida urbana. $\mathrm{O}$ ato do consumo diário

\footnotetext{
${ }^{62}$ Uma noção de arte e, ao mesmo tempo, de clássico atravessa esta característica. A identidade atribuída ao espaço, cujo fundamento se localiza nas estruturas arquitetônicas que remetem ao passado, implica numa espécie de "retorno" ao período em que o Centro de São Paulo vivia seu apogeu de valorização. Se como um espaço de representação o Centro "é o espaço vivido através das imagens e símbolos que acompanham, portanto o espaço dos 'habitantes' e dos 'usadores" (LEFEBVRE, 2000, p.49), do ponto de vista do vivido, é também o espaço que a memória (por meio da imaginação) tenta se apropriar novamente por meio da ressignificação de seus conteúdos.
} 
do espaço, neste caso, atrelado à realização da vida, caracteriza aquilo que podemos chamar de “consumação", que, em lato senso, seria o equivalente ao consumo diário do espaço que permite a realização (e manutenção) da vida, para além do que está posto apenas na unidade habitacional. Assim, se o espaço se realiza sob os determinantes do consumo - e com isso ocorre também a produção social de uma forma de valor -, consequentemente, ele não se realiza na produção. Isso faz com que esta modalidade de uso do espaço torne-se uma determinabilidade que confere ao espaço uma particularidade que nega outra possibilidade de realização ao percorrer as outras fases de realização do capital.

Se a própria forma-valor, mesmo na figura do uso torna-se aquilo que contém a potência de produção da mercadoria (sob os predomínios do valor de troca), este espaço do Centro, por sua vez, contém as características que consequentemente o metamorfoseia em capital fixo e/ou capital fixado. Poderíamos, neste caso, atribuir à forma arquitetônica aquela estrutura que caracteriza o capital fixado no espaço, contudo, este movimento de pensamento vai para além da estrutura arquitetônica como capital fixo e/ou capital fixado no espaço. Isto ocorre porque é o próprio Centro - enquanto um espaço historicamente e socialmente produzido, bem como um fragmento que somente adquire seus significados quando compreendido através da sua relação com a totalidade da metrópole - que atribui à formaarquitetônica sua identidade, bem como sua função, conforme o período histórico e as condições que estão postas. Ao mesmo tempo, o Centro em si não assegura sua identidade sem esta relação com as formas arquitetônicas que constituem parte de seus conteúdos. Neste caso, ao mesmo tempo em que há uma relação de complementaridade, há, também, uma relação de negação que existe através da tensão advinda do momento de reprodução do espaço $^{63}$.

As potencialidades que permitem fazer com que o Centro retorne novamente ao circuito de realização do capital ainda não estão completamente postas em função da sua apropriação popular e/ou proletária, conforme estamos asseverando ao longo desta dissertação. Sua apropriação, portanto, as formas de uso do espaço, tornam-se um impeditivo

\footnotetext{
${ }^{63}$ A reprodução do Centro de São Paulo, principalmente nos distritos Sé e República, tenciona as relações de uso (mesmo que na maioria dos casos seja direcionada pela forma-valor) do espaço a partir do momento que fazem com que a relação de complementaridade entre as formas arquitetônicas e o Centro passe a ser, talvez, o subsídio principal que permita produzir um valor de troca na confecção de uma nova mercadoria. Assim, se a identidade do Centro de São Paulo, constituída também através da diferenciação espacial em sua relação com a metrópole, é atribuída em parte por suas formas arquitetônicas (da mesma forma que o próprio Centro atribui a identidade a estas formas), esta relação de complementaridade torna-se também o objeto de uma negação. Isto ocorre através subverter (e ao mesmo tempo inverter) as formas de uso e apropriação do espaço para atribuí-los novos conteúdos que sejam capazes de devolvê-lo ao circuito de realização do capital, fazendo acentuando ainda mais os traços do espaço-mercadoria, a troca enquanto forma atribuída pelo valor e, por conseguinte, devolvendo os ditames da propriedade privada do espaço.
} 
à sua própria reprodução. A relação entre classes sociais é evidente neste caso, afinal, enquanto houver o predomínio de ocupação de uma classe em específico, o espaço, potencialmente, não adquire condições suficientes para que possa ser posto novamente à troca e, por conseguinte, obter novos compradores. Seu processo de revalorização é também seu processo de segregação, ou seja, o apartamento de pessoas pertencentes a classes específicas que fazem com que o Centro não seja objeto de desejo de novos compradores. Sendo assim, boa parte de seus imóveis (principalmente nos distritos Sé e República) encontram-se em condição de vacância, mesmo que este fator venha diminuindo ao longo dos anos, conforme há seu processo de revalorização. Dessa maneira, enquanto o Centro persiste em seu processo de consumação, o mesmo não pode se realizar por completo no processo de produção, o que faz com que suas potencialidades tornem-se fixadas, porém, ao mesmo tempo, se realizem enquanto potência em latência, fazendo com que desvalorização e revalorização, neste momento, sejam processos que ocorram quase que em concomitância.

Sob restrições de construção do novo, em função da escassez de espaço que caracteriza o Centro de São Paulo (principalmente nos distritos Sé e República), uma via de mão dupla se abre a partir das condições que estão dadas. Se por um lado a escassez de espaço não permite a construção daquilo que seria o novo, no sentido de um conjunto de estruturas que fossem capazes de alterar o conteúdo das formas que caracterizam o Centro de São Paulo, por outro, a apropriação estratégia da própria condição de escassez permite também produzir os conteúdos da raridade, ou seja, aqueles cujos conteúdos que são constituídos em função do que é tradicional, cujas formas tornam-se clássicas e seus papéis passam a ser também de ordem decorativa.

Uma espécie de estética clássica (de formas e estruturas passadas), neste caso do Centro, permite aquilo que talvez seja um retorno a um momento anterior em que os conteúdos de uma estética burguesa atravessavam de maneira mais latente o espaço. Atualmente, se por um lado esta estética permite um retorno ao que podemos considerar como passado por meio da atribuição de uma série de representações para que o Centro seja reocupado por parcelas da pequeno-burguesia, ou, quem sabe, da própria burguesia paulistana; por outro, a mesma estética acoberta todo processo de pilhagem, violência, expropriação e desapropriação que são característicos ao processo de urbanização na atualidade.

O clássico e o elegante que são reproduzidos nas formas sob a justificativa da cultura, reproduzem, agora, os determinantes da forma-mercadoria a partir dos produtos com raridades espaciais específicas, que são produzidos pelo capital. Ferro (2006, p. 338) assevera que "o 
clássico é um universal do capital - com infinitas particularidades”. De certa forma, uma estética do que já foi produzido e tornado clássico, também pode ser uma estética que retome (mesmo que superficialmente) os antigos conteúdos para fins de realização de um novo valor. As estruturas arquitetônicas do Centro de São Paulo ainda permitem (por meio da reprodução de uma forma estética anterior que atualmente pode ser considerada clássica) a produção de sua renovação e/ou reforma como uma espécie de produção de um novo valor de troca de uma mercadoria tornada rara, portanto, clássica.

Esta estrutura arquitetônica, por sua vez, se metamorfoseia em capital fixo a partir do momento em que o espaço desvalorizado passa a ser atravessado por uma série de estratégias que visam repô-lo novamente no circuito do capital de realização do valor. Porém, a partir do momento que o próprio espaço permite com que esta estrutura torne-se capital fixo, a mesma estrutura arquitetônica, diante de um processo de revalorização, faz com que o espaço passe pelo mesmo processo de se metamorfosear em capital fixo.

A reprodução do Centro de São Paulo, como dimensão da reprodução capitalista da metrópole, se realiza enquanto uma negação de sua forma atual (deteriorada em sua morfologia social e espacial). Neste caso, convém salientar que a reprodução do Centro de São Paulo consiste num processo em que sua revalorização se realiza enquanto uma conotação ligada a uma dimensão da luta de classes que se realiza a partir do processo de urbanização. A noção (estrategicamente e ideologicamente posta) de deterioração, leva em conta o atual momento em que o Centro de São Paulo é ocupado, predominantemente, por camadas mais populares e/ou camadas pertencentes ao proletariado que atualmente verifica no Centro da metrópole as condições de trabalho que permitem a reprodução das suas respectivas vidas. Assim, é por meio de uma negação que caracteriza predominantemente sua forma atual (aquela ligada ao processo de popularização, ou, como estamos assegurando nesta dissertação, de proletarização do espaço) que a reprodução do Centro de São Paulo, enquanto processo que também é produtivo, busca reverter o atual momento em que suas estruturas arquitetônicas adquirem um potencial mercadológico. As ações da PMSP ocorrem no sentido de mobilizar uma série de condicionantes que são capazes de fazer com que o espaço se desvencilhe da sua condição de uso e entre, aos poucos, na condição de produção; ou seja, que realize um movimento que saia, cada vez mais, da condição de capital fixo para se tornar capital circulante e, consequentemente, dar sequência nas fases de realização do capital.

No Centro, o espaço socialmente e historicamente produzido passa a ter uma relação com estas fases de realização do capital e, por conseguinte, com sua reprodução que passa a ser marcada também pela relação entre fixo e circulante, bem como uma relação em que a 
negação atravessa as metamorfoses. Enquanto permanece como capital fixo, o espaço, através da realização das formas de uso, torna-se desvalorizado pelo fato de não "entrar" no processo de circulação e, por conseguinte, não se valorizar enquanto momento de valorização do valor (produção do mais-valor). Ao mesmo tempo em que não se realiza plenamente enquanto valor de troca, o espaço constitui também enquanto uma espécie de reserva de valor, afinal, como uma mercadoria em condição de potência em latência, o Centro tende como um espaço privilegiado da metrópole às possibilidades de continuar o processo de acumulação.

Um paralelo significativo que pode ser feito, ressalta a produção teórica de alguns arquitetos que, ao longo da década de 1970, buscaram compreender a relação da arquitetura com as formas de capital fixo, bem como a de força produtiva. Se por um lado Marino Folin ${ }^{64}$ tece suas considerações acerca do uso capitalista do espaço físico, levando em conta que o ser mercadoria da cidade significa que ela seja produto pelo fato de ser meio de produção e meio de consumo. Para este autor, a cidade como meio de consumo leva em conta que o uso constitui a condição material da arquitetura ${ }^{65}$ e esta, por sua vez, deriva da demanda expressada pela necessidade advinda do modo de produção capitalista. Por outro, Sérgio Ferro (2006, p. 139) também nos auxilia nesta forma de entendimento, ao explanar sobre aquilo que considera como a forma manufatureira de produção do espaço ${ }^{66}$, alerta que esta, enquanto uma das manifestações localizadas da luta de classes na produção constitui-se em

\begin{abstract}
reserva contra a queda tendencial da taxa de lucro e fonte privilegiada para a acumulação e reprodução (aumentada) do capital - privilégio acentuado pela extrema mobilidade possível para o capital no setor (custo fixo reduzido). [...] A construção que compõe, de um modo qualquer, parte do capital constante fixo industrial, comercial ou financeiro (galpões, depósitos, estradas, lojas, escritórios etc.) deve ter, comparativamente, baixo valor unitário.
\end{abstract}

Ainda sobre Ferro (2006, p. 139), vale salientar que suas considerações sobre a produção da habitação burguesa e de classe média (sobretudo, classe média alta), é marcada pela "tendência do alto valor unitário, também guardado como reserva alta de capital". Essa "forma manufatureira de produção do espaço" ou mesmo como assinala o autor, essa "elaboração material do espaço ${ }^{67 "}$ é posto pelo autor mais como um "processo de valorização do capital ${ }^{68}$, , ou seja, a construção (ou o espaço construído) tem um papel significativo ao

\footnotetext{
${ }^{64}$ FOLIN, Marino. La ciudad del capital y otros escritos. Mexico, D.F.: Ediciones G. Gili, S.A., 1977.

${ }^{65}$ Ibidem, p. 38.

${ }^{66}$ Meus grifos.

${ }^{67}$ Ferro, 2006, p. 107.

${ }^{68}$ Ibidem.
} 
conferir ao espaço sua condição de capital fixo. Neste sentido, não somente o que será construído, mas também aquilo que está construído também está na condição de incorporação de um novo valor de uso. Se para Ferro esta elaboração material do espaço tem como ponto de partida e fundamento a produção arquitetônica capaz de auferir ao espaço a condição de capital fixo, do ponto de vista qual abordamos a questão do Centro de São Paulo, de avaliarmos como um espaço que é socialmente e historicamente produzido, o espaço adquire sua condição de capital fixo apenas quando é interpretado no movimento totalizante de reprodução da metrópole. Assim, se num determinado período em que a reprodução da metrópole trouxe novos lugares que passaram pelo processo de valorização, atualmente, em concomitância com outros lugares que passam também pelo processo de valorização, o Centro de São Paulo contém em si fixadas todas as condições que permitem sua revalorização.

Nestes termos, não seria exagero pensarmos que os edifícios vazios do Centro de São Paulo constituem-se enquanto capital fixo, alguns já prontos para voltar à circulação, outros não; porém, todos se realizando numa lógica em que suas respectivas representações no contexto do Centro de São Paulo derivam de estruturas que são fixadas em função de distintas determinabilidades e que ao retornarem à condição de forma-mercadoria exige-se também que este estrutura (agora metamorfoseada em capital) se realiza também na esfera da circulação. Capital fixo e, ao mesmo tempo, capital circulante, são formas que se anulam ${ }^{69}$, porém, precisam ser realizadas para superar a desvalorização e assim produzir um novo valor de uso para que o espaço seja novamente consumido. Somente quando o espaço torna-se condição, meio e produto para a reprodução, este também se torna requisito essencial para a revalorização do Centro de São Paulo. De certa forma há um duplo que caracteriza este processo de desvalorização. Por um lado há o processo de desvalorização que ocorre em função da valorização diferenciada dos lugares da metrópole e, por outro, há o processo de desvalorização que ocorre em função das próprias condições de produção, o tempo de permanência das suas formas (enquanto estas, por sua vez, não entram novamente no processo de produção), ou mesmo quando o capital é novamente fixado e desvalorizado. Ou seja, a tendência para a cidade ao longo do regime de acumulação capitalista sempre irá em direção do processo de desvalorização de suas formas.

Aprofundando ainda mais este debate, vale asseverar aqui as considerações de Rodrigo Lefevre (1979), para quem o terreno surtiria como uma matéria-prima para a produção,

\footnotetext{
${ }^{69}$ Se estiver na condição de capital fixo, não é capital circulante; entretanto, se está na condição de capital circulante, não está em condiões de produzir e pôr mais-valor, portanto, de se processar enquanto capital. Enquanto não é lançado no mercado, acaba sendo fixado também como produto; contudo, enquanto permanece no mercado é fixado como mercadoria.
} 
portanto, aparecendo como um capital constante da indústria imobiliária. Para (LEFEVRE, 1979, p.113)

num dado momento de produção desse capital fixo, no momento de construção das moradias para a reprodução da força de trabalho, ou seja, lugar para gente morar, pode haver a utilização do terreno, uma das partes constituintes da cidade, um de seus elementos como capital circulante para a produção de equipamentos ou casas. Esse capital circulante, com valor correspondente à cristalização de uma parcela do trabalho humano empenhado na construção da cidade, pode assumir, para um capitalista que vai produzir mercadoria-construção, não importa qual a finalidade mas que a realiza no mercado, o papel de matéria-prima.

A produção desse capital fixo, qual assevera Lefevre (1979), nada mais é do que a cidade que, agora, aparece como capital fixo. Neste sentido, o terreno começou a aparecer mais como aquilo que considerou uma espécie de matéria-prima para a produção, fazendo parte do capital constante circulante daquela indústria imobiliária ${ }^{70}$. Ou seja, o terreno, enquanto matéria-prima para a construção, nas observações de Lefevre, passou a oferecer então lucros extraordinários nas piores localizações, portanto, aquelas com baixos preços. Foi o que chamou preços que funcionaram de maneira inversa sobre os lucros. Porém, o que vale salientar é que neste momento do processo de urbanização o que vinha ocorrendo nas grandes metrópoles ${ }^{71}$ foi, simplesmente, o processo de explosão das periferias.

No momento em que Rodrigo Lefevre teceu suas considerações sobre o papel do preço dos terrenos em negócios imobiliários, a metrópole paulistana acentuava cada vez mais seu processo de explosão. Assim, mesmo nos lugares onde os terrenos tinha como referência localizações que não eram as melhores, os empreendimentos imobiliários, por sua vez, tinham uma demanda suficiente. Nestas condições os terrenos surtiam mesmo como a "matéria-prima da produção", afinal, a procura por estes empreendimentos imobiliários era feita por uma quantidade significativa de pessoas; o que permitia o lucro mesmo nas piores localizações. Talvez não seria um equívoco enorme de nossa parte em pensar que, nestas condições históricas, os terrenos ainda surtiam como uma espécie de "matéria-prima", como bem asseverou Rodrigo Lefevre, afinal, de fato se formava um mercado com um "preço geral de construção" para o metro quadrado vendido. Atualmente ainda é bem possível que tal "preço feral da produção" seja influente, contudo, outros fatores que são estruturais - tanto do ponto de vista da produção da unidade imobiliária (como por exemplo os materiais de acabamento)

\footnotetext{
${ }^{70}$ Lefevre, 1979, p.97.

${ }^{71}$ Vale salientar que em seu texto, Rodrigo Lefevre (1979, p.95) destaca o estudo de caso para a cidade de São Paulo, contudo, o autor salienta que esta sua leitura possa ser válida para outras cidades como Rio de Janeiro ou mesmo Paris.
} 
quanto do ponto de vista da relação entre a unidade imobiliária e o lugar qual ela se encontra - tendem a criar os próprios nichos e especificidades do mercado imobiliário.

Dessa maneira, poderíamos considerar que as estruturas arquitetônicas dão o tom do espaço produzido do Centro de São Paulo, como também suas infraestruturas e a relação deste espaço com a metrópole como um todo. Para além da propriedade privada do solo, o capital fixo também se realizaria no espaço socialmente produzido. A fixação deste capital literalmente no solo pode ser atribuída e compreendida a partir da produção do espaço, já que o sentido da deterioração (em decorrência da fixação deste capital e o período em que ocorre seu uso) se daria a partir da possibilidade de revalorização. O processo de revalorização do Centro de São Paulo - enquanto uma série de articulações entre Estado, empresas ligadas à indústria do imobiliário, incorporadoras e construtoras - para além da produção de novas representações ligadas às estruturas históricas, torna-se também um processo de produção das condições em que novos perfis de moradores (geralmente identificados aos perfis de classe média) tenham interesse em habitar este fragmento da metrópole. Enquanto este se realiza como um processo gradual, em concomitância com a produção de novas representações do espaço que apontam novas formas de uso ligadas, por exemplo, aos elementos culturais, ocorreu (e ainda há) também o fenômeno da vacância de imóveis que aprofundam ainda mais as contradições ligadas à raridade do espaço no Centro.

A tendência que deriva destas relações e as condições que ocorrem no Centro de São Paulo, é que a contradição entre os edifícios inteiramente vagos em um espaço superedificado reverbere nas taxas de ocupação ou não dos edifícios, cujos proprietários preferem o melhor momento deste processo (de revalorização) para negociá-los. A vacância imobiliária no Centro de São Paulo surge desta condição em que o espaço do Centro passa a se realizar de maneira mais incisiva sob as determinantes do valor de troca, posto a partir do novo valor de uso que deve ser produzido através da reprodução do espaço. Os imóveis (em alguns casos, até prédios inteiros), sob os olhos do investidor que vislumbra no Centro da metrópole um fragmento com potenciais significativos de acumulação, metamorfoseiam-se em capital fixo, pois, enquanto trabalho morto, bastaria "apenas" alguns processos de trabalho vivo ${ }^{72}$ para que estes se redefinissem conforme os conteúdos da representação que estariam (e estão)

\footnotetext{
${ }^{72}$ Levando em conta que muitos dos edifícios encontram-se sob a condição de bens tombados, exatamente para preservar os elementos construídos, a tendência é que o valor atribuído através de conteúdos históricos se transfira para a propriedade arquitetônica, para a paisagem e, consequentemente para o lugar. Neste sentido, a condição de raridade é apropriada para que um valor se realize a partir da revalorização do Centro. Assim, enquanto "trabalho morto", portanto, enquanto trabalho já fixado no espaço, estes edifícios tombados que atribuem um valor "cultural" atrelado ao lugar, passam a ser então objetos de reforma (logo, de mais-trabalho e/ou de trabalho vivo) para que o novo valor também se realize através desta forma.
} 
atribuídos a este fragmento. Assim, manter os edifícios vagos até o momento em que o Centro fosse objeto de desejo e consumo de uma fração da população que estivesse disposta a pagar pelo espaço, agora, com novos conteúdos, aos olhos do investidor não seria, talvez, um mau negócio. A "herança cultural", a raridade em ser um imóvel histórico e a diminuição dos gastos, em função de realização dos processos de reforma, tornam-se elementos essenciais para a revalorização do Centro de São Paulo. Tendo cada vez mais sua "imagem" ${ }^{73}$ " atrelada aos conteúdos da cultura, o Centro sob estas novas representações seria o espaço de novos prazeres, tanto sensitivos (pelo fato da possibilidade de comprar uma parcela de espaço privado e assim disfrutar toda uma atmosfera cultural) quanto emocionais. No que tange ao emocional, uma forma de, talvez, decorar a moradia com os conteúdos da cultura, seria uma forma também de fazer com que o espaço do habitar se realizasse de acordo com esta atmosfera cultural. No momento da revalorização, os conteúdos do processo de urbanização se complementam através das mediações que se realizam no valor de troca e contribuem com a produção de novas formas que buscam se realizar sob a condição de mercadoria.

Se o processo de desvalorização caracterizou o fenômeno da vacância ${ }^{74}$ imobiliária no Centro de São Paulo e expôs o espaço como mais uma das novas formas que, ao serem produzidas, permitem ou permitiram a acumulação; a reversão deste processo (neste caso, assentada na própria revalorização) corrobora com a centralidade do espaço-mercadoria enquanto nova possibilidade de reprodução do capital. Levando com conta os dados do Censo de 2000 e do Censo de 2010, e, por conseguinte, considerando também a dinâmica das estratégias postas pela PMSP para a revalorização deste fragmento da metrópole, as mudanças ganharam significância no movimento em que o Centro e seu entorno passam a repercutir os novos significados da revalorização do espaço socialmente produzido.

A variação das condições dadas anteriormente (de Centro e entorno deteriorado, desvalorizado com formas características em função da paisagem), talvez tenha ocorrido em função das políticas urbano-territoriais ou mesmo das estratégias políticas (postas em prática pela PMSP), para fins de revalorização do Centro de São Paulo e seu entorno. Os empreendimentos políticos ${ }^{75}$ postos em movimento pela PMSP correspondem ao acúmulo de estratégias políticas que, somadas às estratégias do mercado imobiliário, caracterizam o atual

\footnotetext{
${ }^{73}$ Neste caso, levando em conta aquele que pode ser, talvez, um misto entre a paisagem e o lugar.

${ }^{74}$ Salientando mais uma vez este fenômeno como uma das também novas contradições do espaço.

75 PROCENTRO, Operação Urbana Centro, Concessão Urbanística "Nova Luz", Arco do Tietê (fragmento) e Arco do Tamanduateí (fragmento), as estratégias voltadas à revalorização sob o álibi da Cultura, atualmente o "Território de interesse da cultura e da paisagem" (TICP Paulista/Luz), fortalecimento do chamado "Polos de Comércio e Desenvolvimento de Moda (Brás, Pari e Canindé)", fortalecimento dos "Polos Comerciais Especializados" (25 de Março, Santa Ifigênia, Bom Retiro, Gasômetro e Zona Cerealista).
} 
momento de revalorização do espaço no Centro de São Paulo. A diminuição significativa da taxa de vacância nos distritos do Centro (ver tabela 02) soa como fato consumado deste movimento em que a reprodução capitalista do Centro já apresenta alguns resultados.

Tabela 2 - Variação da Taxa de Vacância nos Distritos do Centro de São Paulo entre os Censos de 2000 e 2010

\begin{tabular}{|c|c|c|c|c|c|c|c|c|c|}
\hline \multicolumn{5}{|c|}{ Censo 2000} & \multicolumn{5}{|c|}{ Censo 2010} \\
\hline Distrito & Particular & $\begin{array}{c}\text { Particular } \\
\text { vago }\end{array}$ & $\begin{array}{c}\% \text { no } \\
\text { Distrito }\end{array}$ & $\begin{array}{l}\% \text { ao } \\
\text { MSP }\end{array}$ & Particular & $\begin{array}{l}\text { Particular } \\
\text { vago }\end{array}$ & $\begin{array}{c}\% \text { no } \\
\text { Distrito }\end{array}$ & $\begin{array}{l}\% \text { ao } \\
\text { MSP }\end{array}$ & $\begin{array}{c}\text { diferença de } \\
\% \text { dos } \\
\text { Distritos }\end{array}$ \\
\hline Sé & 7.695 & 3.055 & 39,7 & 0,73 & 10.627 & 1.246 & 11,7 & 0,42 & $-28,0$ \\
\hline República & 20.923 & 7.007 & 33,5 & 1,67 & 32.180 & 3.732 & 11,6 & 1,27 & $-21,9$ \\
\hline Brás & 8.300 & 2.789 & 33,6 & 0,66 & 12.301 & 1.664 & 13,5 & 0,57 & $-20,1$ \\
\hline Pari & 4.387 & 1.223 & 27,9 & 0,29 & 6.178 & 556 & 9,0 & 0,19 & $-18,9$ \\
\hline Santa Cecília & 26.220 & 6.343 & 24,2 & 1,51 & 40.583 & 3.024 & 7,5 & 1,03 & $-16,7$ \\
\hline Liberdade & 21.993 & 5.283 & 24,0 & 1,26 & 31.597 & 3.166 & 10,0 & 1,08 & $-14,0$ \\
\hline Cambuci & 8.930 & 1.910 & 21,4 & 0,45 & 14.366 & 1.201 & 8,4 & 0,41 & $-13,0$ \\
\hline Bom Retiro & 8.246 & 1.821 & 22,1 & 0,43 & 12.214 & 1.114 & 9,1 & 0,38 & $-13,0$ \\
\hline Bela Vista & 24.735 & 5.479 & 22,2 & 1,30 & 35.781 & 3.494 & 9,8 & 1,19 & $-12,4$ \\
\hline Consolação & 21.802 & 3.694 & 16,9 & 0,88 & 32.076 & 2.890 & 9,0 & 0,98 & $-7,9$ \\
\hline Total Distritos & 153.231 & 38.604 & 25,2 & 9,18 & 227.903 & 22.087 & 9,7 & 7,52 & $-165,9$ \\
\hline MSP & 2.992 .656 & 420.327 & & & 3.930 .530 & 293.621 & & & \\
\hline
\end{tabular}

\section{Legenda}

Particular: domicílios particulares.

Particular vago: domicílios particulares vagos, portanto, não ocupados.

\% no Distrito: percentual de domicílios não ocupados no referido distrito.

\% ao MSP: percentual de domicílios não ocupados do distrito em relação ao município de São Paulo.

Diferença de \% dos Distritos: diferencial de percentual de vacância nos Distritos entre os anos do Censo.

Total dos Distritos: total dos dados inerentes aos Distritos que correspondem a área central nesta pesquisa.

Fonte: Prefeitura Municipal de São Paulo, PMSP.

Organização e elaboração: Gilmar Soares, 2015.

Quando considerados os dados gerais de todos os distritos que compõem a cidade de São Paulo, os distritos Sé, República, Brás, Pari e Santa Cecília correspondem aos distritos que mais tiveram a reversão do fenômeno da vacância imobiliária total da cidade. Outro fator relevante está no aumento do número de unidades particulares de domicílios, pois, de 2000 para 2010 o aumento de domicílios particulares nos distritos do Centro de São Paulo teve uma taxa de crescimento que chegou próximo aos $33 \%{ }^{76}$. Por mais que houvesse o aumento das unidades particulares (o que corresponde também aos lançamentos imobiliários de novos empreendimentos), houve também a diminuição da taxa de vacância nos respectivos distritos. Vejamos, por exemplo, o caso do distrito Sé que passou por uma variação negativa de $-28 \%$

${ }^{76}$ Das 153.231 unidades domiciliares correspondentes ao ano 2000, para as 227.903 em 2010, sendo o diferencial de crescimento o total de 74.672 unidades. 
da reversão da vacância imobiliária. Além do aumento em $27 \%$ do número de unidades particulares de domicílio, houve neste distrito a diminuição significativa da taxa de vacância, de 39,7\% no Censo de 2000 para 11,7\% no Censo de 2010, representando a maior diminuição da cidade de $28 \%$, conforme os dados da tabela.

A reversão da taxa de vacância que ocorreu praticamente em todos os distritos, foi acompanhada pelo aumento do número de unidades domiciliares. No período de 10 anos que separam os Censos, o maior aumento do número dessas unidades ocorreu no distrito Santa Cecília com um saldo positivo de 14.363 unidades, seguido pelo distrito República que apresentou uma variação positiva de 11.257 unidades domiciliares, e que também localiza-se "ao lado" do distrito Santa Cecília. Além do distrito Santa Cecília e República, o distrito Bela Vista (um pouco mais distante dos distritos Sé e República e influenciado pela dinâmica da Avenida Paulista) apresentou um saldo positivo de 11.046 unidades, acompanhado do distrito Consolação (também influenciado pela dinâmica imobiliária que ocorre nas proximidades da Avenida Paulista e do bairro do Higienópolis) que apresentou um salto de 10.274 unidades, fechando assim o grupo dos distritos que tiveram crescimento acima das 10.000 unidades domiciliares habitacionais. Se formos considerar outra "possível classe" de distritos que tiveram crescimento de unidades domiciliares entre 5.000 e 10.000 unidades domiciliares, a dinâmica inerente a esta quantidade ocorreu nos distritos Liberdade, com 9.604 unidades, e Cambuci (mais afastado e com maior característica de bairro residencial) com 5.436 unidades. Entre os distritos que apresentaram aumento de número de unidades domiciliares de " 0 " até 5.000 unidades, restam: Brás com 4.001 unidades, Bom Retiro com 3.968 unidades, Sé com 2.392 unidades e Pari com 1.791.

Levando em conta que o distrito Sé foi o que apresentou a maior diferença de reversão da taxa de vacância de todos os distritos da cidade de São Paulo, e levando em conta também que de todos os distritos que compõem o nosso recorte espacial de estudos o distrito Sé somente ficou atrás do distrito Pari em número de aumento de unidades domiciliares, outra hipótese (que ao mesmo tempo se realiza) que fundamenta nosso argumento sobre o processo de revalorização do Centro de São Paulo é o fenômeno dos imóveis reformados.

A paisagem, deteriorada e/ou degrada pela ação do tempo nas estruturas arquitetônicas torna-se um fator positivo que tende a diminuir ainda mais o preço dos imóveis no Centro de São Paulo, o que, em teoria, permite o avanço das compras dos mesmos para a realização desta prática de reforma que, cada vez mais, ganha novo fôlego e abre as possibilidades dos negócios imobiliários no Centro de São Paulo. Além do Retrofit, outro fato está na possibilidade de realização de novos negócios com a possibilidade de novos empreendimentos 
nos distritos que, até então, tiveram baixa dinâmica imobiliária (distritos Bom Retiro, Pari e até mesmo o Brás). Na reprodução do Centro de São Paulo, o processo de revalorização do espaço se realiza na esteira das estratégias que, em diversos momentos, coadunam as praticas da indústria do imobiliário em São Paulo e a Prefeitura Municipal. A desvalorização serve tanto ao empreendedor imobiliário que compra os imóveis a um preço menor, quanto à PMSP que põe em prática suas políticas e estratégias que visam reverter o caráter popular, portanto, marcado pelo aumento da ocupação proletária deste fragmento da cidade.

No que tange à reprodução do Centro, a relação entre a Prefeitura Municipal e a metrópole se realiza na liberação dos estoques para se construir nestes distritos, ainda mais considerando a tendência de acentuar nos distritos com menor grau de densidade construtiva, como é o caso dos distritos Bom Retiro e Pari. Enquanto as estratégias no geral giram em torno de "trazer a classe média novamente para o Centro de São Paulo", a produção de novas unidades habitacionais com características atuais nestes distritos próximos aos distritos Sé e República unem as perspectivas do mercado imobiliário com as estratégias da PMSP.

\subsection{A REVERSÃO dO “IMPASSE" DA PROPRIEDAdE PRIVADA dO SOLO NO CENTRO DE SÃo Paulo}

A revalorização do Centro de São Paulo, que se realiza por meio de um processo de reprodução de seu próprio espaço, revela a dinâmica global de um processo de mundialização do espaço que, para além de um modelo de urbanização neoliberal, aponta o momento de reprodução também como aquele da homogeneidade das formas que se tornam mundial e tendem à imposição na escala do lugar. O processo de revitalização de fragmentos da cidade ocorre não apenas em áreas Centrais, como também em bairros, portos etc, e ocorre, praticamente, em diversas cidades do mundo, tanto nas metrópoles quanto nas cidades de menor porte. O fenômeno também não é tão atual, aliás, é um fenômeno da modernidade, cuja lógica das transformações gira em torno da mercadoria.

No Centro de São Paulo as estratégias para sua revitalização decorrem desde a década de 1970, contudo, as políticas mais específicas e incisivas para a realização deste processo vêm ocorrendo desde o final da década de 1980. Distinguida pelo caráter específico de adensamento do espaço construído, a propriedade privada do solo no Centro de São Paulo ganhou novos significados (tanto ideológicos quanto econômicos) após o Centro ter se tornado o espaço de moradia de classes mais populares. O processo progressivo de proletarização do Centro de São Paulo pode ser interpretado também em função da sua especialidade, afinal, a proximidade com os locais de trabalho ou mesmo a proximidade com 
os lugares em que há possibilidades de exercer atividades de remuneração baixa e imediata (como é o caso do trabalho informal), fez com que a apropriação do Centro pelas classes mais populares atribuísse ao espaço um novo sentido, na maioria das vezes, considerado como pejorativo.

Desde meados da década de 1980, quando houve essa volta das classes mais populares ao Centro de São Paulo, houve também o reforço de uma identidade que geralmente esteve atribuída a este fragmento. Historicamente, o Centro foi objeto de disputa das classes sociais que ali ganhavam proximidade e as formas de separação geralmente eram movidas por álibis específicos, como por exemplo, o período da higienização. Historicamente, também atrelado ao Centro, o fenômeno das ocupações precárias serviram de álibi para as remoções que as justificavam como espaços insalubres. Podemos pensar que o Centro foi constantemente o espaço de disputa entre as classes e tais disputas sempre caracterizaram em novas geografias e novas espacialidades, tanto no surgimento de novos bairros quanto na reordenação morfológica feita pelo Estado. A ocupação popular deste espaço geralmente foi posta como um "impasse" às camadas burguesas da sociedade e, geralmente, a resolução para este "impasse" foi de encontro em espalhar pela cidade a massa proletária que nela se concentra cada vez mais.

A história mostra como que na cidade os problemas das classes foram resolvidos pela burguesia: morfologicamente falando, o espaço abstratamente e estrategicamente pensado serviu para a separação das classes, ao mesmo tempo em que também serve para a reprodução das suas condições de existência; politicamente falando, a separação do proletariado pela cidade explodida e implodida também é uma forma estratégica de enfraquecê-lo enquanto massa homogênea que é explorada, e que, enquanto contingente negativo, porta uma potência revolucionária incomensurável. A segregação socioespacial (que também é a separação das classes em fragmentos mais ou menos homogêneos, tanto das cidades quanto dos sujeitos) apenas enquanto condição espacial e apurado mecanismo político e econômico, pode ser considerada relativamente inerme diante de sujeitos com potência revolucionária, por isso outro fator deve ser considerado. Necessária nesse processo é a representação política do Estado enquanto reforço da condição política da separação, entretanto, levando em consideração sua violência, seus aparelhos e sua forma de ser, entendida na homogeneização dos sujeitos (enquanto sujeitos de direito) e numa espécie de "humanização do capital" (entendida na relação que homogeneíza a pessoa jurídica à pessoa física) em que todos se tornam iguais perante a lei, portanto, perante o Estado. Historicamente é o Estado quem "resolve" a luta de classes (sempre oprimindo e pilhando a classe dominada) e, no caso do 
Centro de São Paulo, atualmente, para resolver o "impasse" da propriedade privada do solo urbano o Estado é o ente de classe por excelência que tem o know-how para resolver o "impasse" e o savoir-faire para ainda revertê-lo em mais-dinheiro. Um fator também deve ser posto em questão: além de métodos já convencionais ancorados nos pressupostos da lei e do direito, vale destacar também o caráter militar relacionado ao processo de urbanização ${ }^{77}$. Não seria um exagero pensar que, na atualidade, a militarização torna-se uma prática (ou mesmo um método) praticamente inerente ao processo de urbanização. A violência inerente ao processo de urbanização também tem como característica diversos desdobramentos e, entre estes, podemos destacar a atualidade do caráter militar. As ações militares, geralmente postas em prática pela polícia, se diferenciam nos bairros, nas situações destes bairros bem como da cidade. A ação militar no processo de urbanização desenrola-se desde formas de atuar brutalmente em processos de desocupação - e o Centro de São Paulo é, infelizmente, o lugar em que isto ocorre, por "excelência" - até ações de repressão das populações mais pobres e marginalizadas em diversos pontos da metrópole, porém, principalmente nas periferias ${ }^{78}$. Vislumbrar o processo de urbanização levando em conta essa dimensão que também é militar, nos conduz a pensar sobre os métodos e formas de atuação que são postas em prática pelo Estado para manter as formas que regem e determinam o regime de acumulação. Desta maneira, não seria também um exagero pensarmos que o grau de coerção, uso do poder e da violência (como mantenedores e garantidores do processo de urbanização) são também medidas que garantem a manutenção da propriedade privada.

A questão do impasse da propriedade privada do solo urbano é delicada, afinal, sua interpretação sempre tende para interpretação em função de um ponto de vista específico que pode ser o ponto de vista de classe. Assim, geralmente a "primeira vista" da questão é aquela que atravessa a lógica das formas de sociabilidade burguesa nas formas das relações de compra e venda. Atualmente a propriedade privada do solo urbano passa a ter, também, sentido de investimento ${ }^{79}$ e com isso, tendencialmente, as assimilações e concepções sociais a seu respeito, levam em consideração as relações de compra e venda e a "segurança" do dinheiro aplicado. Qualquer variância na conjuntura, instabilidade social ou mesmo

\footnotetext{
77 A pertinência e originalidade desta avaliação competem a professora Cibele Rizek que, em sua contribuição aos nossos estudos, apontou este traço atual do processo de urbanização que coaduna com a luta de classes que também deriva desta dimensão da realidade.

${ }^{78}$ Voltaremos a esta discussão da militarização do processo de urbanização mais adiante.

${ }^{79}$ É comum nos anúncios de imóveis ver a unidade habitacional atrelada a uma forma de investimento que mobiliza e fixa a renda em uma determinada forma que, com várias ressalvas, acaba sendo considerada como forma geradora de renda, a não ser que o proprietário a alugue ou a arrende de alguma maneira.
} 
reconfigurações na cidade são princípios que tendem a influenciar no preço do metro quadrado.

Objeto de investimento, o espaço assegura em si estas características em que as representações do lugar constituem os atributos que qualificam o produto imobiliário. Além da propriedade privada do solo urbano, o espaço todo é posto à venda. As estratégias de marketing dos novos empreendimentos imobiliários se apropriam destas condições. Por exemplo, se com os imóveis da Mooca eles "vendem" as cantinas e a representação italiana do bairro, em Pinheiros eles "vendem" o charme, a gastronomia, a vida nos bares da Vila Madalena e a proximidade com a centralidade. Com os imóveis da Vila Romana na zona oeste é o mesmo, porém, atrelados à venda de uma dinâmica de Perdizes e também Vila Madalena. Os lugares de São Paulo, quando não portadores de uma representação são postos à venda travestidos com a representação de outros bairros. Talvez este fetiche pelo espaço seja uma das chaves que permita explorar como que, "travestidos" com a representação de outros bairros, os lugares de São Paulo tendem potencialmente à realização contínua do valor de troca. A parcela do Centro de São Paulo, nesse caso, fica toda reservada à representação da cultura que a ele é atribuída. Nesse caso, a potência da cultura está em auferir à propriedade privada do solo um valor específico que se realiza nas possibilidades de realização de um novo uso e apropriação deste espaço com acúmulo de equipamentos culturais.

O espaço público contém sua especificidade na dimensão política da produção do espaço em função infraestrutura urbana que nele está construída e que, em muitos casos, torna-se também fator de valorização dos lugares ${ }^{80}$. Outra dimensão política fica reservada às intervenções no espaço da metrópole, através da delimitação de territórios estratégicos para a realização de obras técnicas que metamorfoseiam significativamente o espaço e lançam-no novamente ao mercado. A dimensão política da reprodução do espaço consiste no fato de que estas intervenções no Centro realizada pela PMSP também faz parte, enquanto momento constitutivo, dos mecanismos que valorizam o espaço e permitem a realização do negócio de compra e venda de imóveis.

A dimensão política do espaço consiste também no momento em que o Estado, ao delimitar estrategicamente um território de intervenção, põe em suspensão praticamente tudo

\footnotetext{
${ }^{80}$ Mais do que uma relação de valor que também é caracterizada pelo trabalho acumulado no lugar, nesse caso, o que é mais interessante é como que a infraestrutura pública (parques, praças, espaços poliesportivos, metrô, proximidade com o aeroporto, proximidade com vias de circulação rápida etc.), no contato com o espaço privado (em sua totalidade) passa a ter também valor auferido através de permutabilidade. Este é o sentido que acentuamos quando comentamos sobre a extensão do valor de troca, afinal, no momento em que se objetiva a mobilização do imobiliário a lugar qual se localiza o imóvel também passa a ser objeto que aufere valor de permuta ao bem e, consequentemente, sua valorização.
} 
que está localizado neste território, inclusive a propriedade privada do solo urbano. O papel do Estado, neste momento, é liberar o espaço para que a fração burguesa, que controla o mercado imobiliário, possa por em prática a apropriação de propriedades privadas do espaço para fins de transformá-las (elevá-las a um novo valor de uso), portanto, produzi-las enquanto mercadoria que possa ser vendida novamente. $\mathrm{O}$ momento em que a propriedade privada do solo urbano se metamorfoseia do uso para a troca, é também o momento do seu ir-sendo (objeto de nova utilidade e necessidade social para que haja a valorização do valor, através da conservação do valor de troca), enquanto um dos fundamentos que a realize posteriormente como forma-mercadoria. Uso e troca são relações sociais determinadas que atribuem à propriedade privada do solo urbano uma determinação econômica enquanto tendência à forma-mercadoria no movimento geral da produção do espaço que também é um momento da reprodução capitalista da metrópole. E, no caso da cidade e do urbano, é a própria relação entre uso e troca que constitui a contradição fundante que gera o impasse qual estamos fazendo o esforço de expor da maneira mais didática possível neste capítulo.

A reprodução do Centro de São Paulo é realizada através das próprias representações que este fragmento da metrópole comporta, ou seja, por meio também da condição histórica de trabalho acumulado no lugar (nesse caso, a cultura desempenha um papel importante) é que, atualmente, se desenrola o entrecruzamento de várias estratégias com algumas políticas. O espaço nessas condições carrega uma dupla característica ao ser analisado pelo viés dos interesses de classe: 1) é objeto direto de interesses no desejo de sua apropriação, e isso corresponde tanto a sua possível proletarização quanto ao seu possível aburguesamento; 2) a sua reprodução é também uma forma atual de acumular capital e, nesse caso, somente burguesia e pequena burguesia ligadas à indústria do imobiliário tiram proveito. No Centro Histórico, onde a cultura finca suas estruturas para imprimir identidade ao espaço, a raridade predomina e, somado a este fator cultural, lança potencialmente o espaço do Centro às lógicas da acumulação. O mesmo acontece com seus arredores, mais ou menos denso também, com lugares mais popularizados por ocupações predominantemente proletárias ou os lugares mais aburguesados.

O processo de revalorização do Centro de São Paulo, para além dos distritos Sé e República, também influencia diretamente nos distritos que compõem o entorno dos distritos que formam o Centro Histórico e a Praça da República; principalmente naqueles que compõem a porção noroeste. A fronteira urbana de acumulação tem como referência também a reprodução do espaço destes bairros, para fins de produzir uma espécie de identidade homogênea neste fragmento da metrópole. Se apropriar da identidade do bairro revertendo sua 
condição de ser um espaço predominantemente ocupado pelo proletariado atual, seria, talvez, um dos maiores desafios para os agentes e sujeitos ligados ao processo de revalorização. Sua ocupação proletária revela, atualmente, a importância do espaço para a reprodução da vida e como o mesmo passa a ser o objeto direto para interesses distintos das classes sociais em São Paulo. Insisto na consideração de como que estas referidas identidades são construídas pelas formas de como o espaço é apropriado, bem como da maneira em que geralmente (ou predominantemente) ocorrem as relações cotidianas da vida prática. Algumas características atuais nos auxiliam, vejamos. O Bom Retiro que já foi de ocupação predominantemente operária, hoje é ocupado por trabalhadores do comércio e serviços, da mesma forma que é caracterizado pelo comércio e confecção de roupas. No comércio, o bairro foi (ou ainda é) também o retiro, não tão bom assim, do trabalho escravo ${ }^{81}$ de bolivianos e haitianos que, ao trabalharem em grande parte na costura, produzem ali peças de roupas de grifes sofisticadas, caras e aburguesadas, para serem vendidas em lojas também sofisticadas de shoppings; talvez alguns desses shoppings estejam em lugares mais aburguesados da cidade (se não estão, vendem para outras burguesias e pequena-burguesia). A Luz é o bairro da estação, do Parque, dos Museus, mas também é o bairro da ocupação Mauá, da ocupação Prestes Maia, de várias ocupações; é também o bairro da cracolândia, da concentração dos moradores em situação de rua, da "operação sufoco" desenvolvida pela polícia militar.

Já o bairro do Pari, de ocupação predominantemente operária no passado, guarda até hoje as características de um bairro onde as crianças, em alguns finais de semana pelo menos, ainda jogam bola nas ruas próximas a igreja Santo Antônio do Pari; há ainda alguns pequenos armazéns que, pasmem, vendem para alguns moradores pequenas compras pelo "método de caderninho". O Pari também é o bairro da comunidade boliviana, talvez em função da proximidade com os postos de trabalho no Brás; nele o tempo de apropriação do espaço criou aquilo que podemos considerar como a identidade boliviana do bairro, bem como sua apropriação para a realização da Feira Kantuta. O Brás, contíguo ao Pari, famoso no país por seu comércio de roupas que toma quase o bairro todo, é o lugar também dos cereais (Zona Cerealista), mas também da continuidade das apropriações populares do lugar. Estes três bairros principais ${ }^{82}$ que circundam os Distritos Sé e República em sua porção noroeste,

\footnotetext{
${ }^{81}$ http://www.prsp.mpf.mp.br/sala-de-imprensa/noticias_prsp/noticia-419

http://www.brasil.gov.br/cidadania-e-justica/2014/08/fiscalizacao-do-ministerio-do-trabalho-retira-31trabalhadores-de-trabalho-escravo

http://reporterbrasil.org.br/2014/05/de-novo-fiscalizacao-flagra-escravidao-na-producao-de-roupas-da-m-officer/ 82 Vale lembrar que outros bairros também compõem estes distritos que configuram o entorno noroeste dos Distritos Sé e República, sendo eles o Bairro de Santa Ifigênia, os Campos Elíseos, o bairro Armênia e o bairro do Canindé,
} 
quando não separados dos distritos Sé e República pela várzea do Rio Tamanduateí, foram separados também pelo traçado da linha do trem. Acredito que, por serem historicamente bairros operários, algumas fronteiras socialmente produzidas (a várzea do Rio Tamanduateí e o Parque Dom Pedro, bem como a linha férrea) se consolidaram com mais "eficiência".

Se apropriando de uma avaliação de Nicolau Sevcenko, Regina Oliveira (2014) atribui a estes bairros como a parte renegada do fenômeno urbano, já que, historicamente, a identidades foram construídas em função da concentração de boa parte da residência de operários, dos cortiços, das atividades de produção, bem como da concentração massiva de comércio popular. Ou seja, não seria um exagero de nossa parte levar em conta que as representações do espaço que ainda predominam para este fragmento da metrópole ainda sejam aquelas que historicamente foram atreladas a classe operária que habitou estes bairros. Assim, estes bairros operários contíguos ao Centro de São Paulo contêm suas respectivas identidades em função das representações que são específicas ao seu espaço, bem como a reprodução destes em um contexto de reprodução da metrópole.

O momento da desvalorização do Centro de São Paulo é também o momento em que estes bairros também passam por transformações que são significativas para avaliar que o processo de desvalorização, por mais que ocorram em alguns lugares de maneira mais incisiva, há um reflexo em outros espaços que guardam uma devida relação. Para (OLIVEIRA, 2014, p. 33), o Brás,

\begin{abstract}
apesar de sua proximidade com o centro histórico, até pouco tempo não estavam entre as áreas prioritárias do poder público para intervenções. No entanto, desde o século XIX, esses bairros vêm sofrendo os impactos de processos não concretizados no perímetro central da cidade de São Paulo e, quando passaram a ser estratégicos para o mercado imobiliário, começaram a ter sua paisagem gradualmente alterada.
\end{abstract}

A partir do momento em que o deslocamento da atividade industrial implicou numa espécie de esvaziamento de galpões e instalações industriais no bairro do Brás, no final da década de 1970 e ao longo da década de 1980, novas condições surgiram para que novas atividades econômicas ligadas ao setor terciário pudessem ser realizadas. Assim, o comércio varejista e atacadista, bem como o comércio ambulante, estes, predominantemente movido pela indústria do vestuário, irão implicar em novas dinâmicas para o bairro do Brás e os bairros vizinhos. As condições estruturais - principalmente aquelas arquitetônico-urbanísticas - que foram praticamente deixadas pela indústria de transformação permitiram uma espécie de readaptação do bairro como concentrar neste espaço todo aparato produtivo inerente a esta indústria do vestuário. Esta redefinição, que vem a reboque também do processo de 
desvalorização, permitiu o surgimento de novas características como a locação habitacional (geralmente a custos baixos) e a proximidade entre o domicílio e o local de trabalho ${ }^{83}$, neste caso, atrelado a esta composição industrial ligada à produção de vestuários.

Conforme observado nas visitas a campo, a apropriação do espaço também se realiza de forma lúdica, tanto nas proximidades do Brás quanto do Pari, onde ainda é possível ver também meninos empinando e correndo atrás de pipas ao longo da Avenida do Estado e nas proximidades com a Avenida Cruzeiro do Sul. Entre o Brás e a Sé está aquele que talvez o lugar mais conhecido do Centro de São Paulo, senão um dos lugares mais conhecidos: o Mercado Municipal e Rua 25 de Março. Num pequeno fragmento entre a Avenida do Estado, a Avenida Senador Queiroz, a Avenida Prestes Maia/Vale do Anhangabaú e Praça da Sé, esteja, talvez, um dos lugares em que o espaço torna-se mais raro e escasso. É o lugar onde estão também pontos turísticos (Mercado Municipal, Pátio do Colégio, Praça da Sé, Mosteiro São Bento, Prédio do Banespa, Viaduto do Chá e o chamado triângulo histórico do Centro antigo). Neste que podemos considerar, talvez, como um fragmento nordeste ${ }^{84}$ do Centro de São Paulo, o lugar ainda guarda como características formas populares de sua apropriação.

Nos trabalhos de campo, observamos também que a apropriação da paisagem consistiu no reconhecimento do lugar que, através dos trajetos, nos permitiu entrar em contato com uma realidade não tão explícita do Centro de São Paulo. Tomando como ponto de partida a Praça da Sé, fui sentido a Avenida do Estado, passando pela Rua Tabatinguera e, se deslocando pelas ruas do Glicério ${ }^{85}$, pude observar casas proletárias (Vilas Operárias) que praticamente ficam "escondidas" tanto pela paisagem vertical do Centro de São Paulo quanto pela geomorfologia que as dissimula. Estas Vilas Operárias ficam “escondidas” na vertente que vai da parte alta ${ }^{86}$ até o fundo de Vale, nas proximidades do Parque do Parque Dom Pedro. No fragmento que se inicia nas proximidades do terminal de ônibus e se estende pela Avenida do Estado, passando pela Várzea do Glicério, passa-se também por uma parte pequena e popular da Mooca e pela "parte baixa" do Cambuci, estes também predominantemente marcados pela ocupação mais popular.

Estes dois últimos bairros, Mooca e Cambuci em seus fragmentos arredores do Centro, compõe o espaço com potência de reprodução, afinal, além de estarem contíguos aos distritos Sé e República, há nestes bairros extensas e antigas áreas industriais prontas para serem

\footnotetext{
${ }^{83}$ Oliveira, 2014, p. 29.

${ }^{84}$ Como um arco que vai do fragmento norte no Bairro do Bom Retiro até a divisa do que podemos considerar também fragmento sudeste, nas proximidades com a Mooca, o Cambuci e a baixada do Glicério.

${ }^{85}$ Para aprofundamentos sobre o bairro do Glicério, ler Canton (2007).

${ }^{86}$ Que vai do Bairro da Liberdade, pela Rua Conselheiro Furtado, depois passa pela Praça da Sé e por fim chega ao Pátio do Colégio, ponto alto que permite ver o terminal de ônibus às margens da Avenida do Estado.
} 
lançadas ao mercado ${ }^{87}$. Proletário e/ou popular, a baixada do Glicério é um lugar também adensado de cortiços, que "vive e sobrevive escondido" debaixo da via expressa Radial Leste, até as proximidades com o bairro da Liberdade. Na Liberdade, o espigão divisor de águas põe em evidência a mimetização oriental que, ao mesmo tempo em que atrai turistas para consumir o bairro e a gastronomia do oriente, dissimula o passado negro dos escravos que ali se concentravam e eram enforcados em praça pública, no antigo Largo da Forca que, estrategicamente, talvez, chama-se hoje de Praça da Liberdade. Nem todo bairro da Bela Vista é de classe média ou aburguesado, na sua "parte baixa", exprimido entre as vias arteriais que recortaram todo o Centro de São Paulo, há ainda uma apropriação popular do lugar por classes mais populares que se estende até algumas partes do Bixiga. Neste fragmento sudeste do Centro de São Paulo, predomina também a ocupação popular, incidência de cortiços e moradores em situação de rua nas proximidades do Parque Dom Pedro. Algo que chamou muita atenção nas diversas idas a campo, é que os lugares mais populares do Centro de São Paulo, em termos de moradia e habitação, são os lugares que ficam às margens das vias rápidas de circulação (Radial Leste, Avenida 9 de Julho, Avenida Prestes Maia/Avenida 23 de Maio, Avenida Tiradentes, Avenida do Estado e Marginal Tiete).

Ocorre que o Centro de São Paulo não é também todo caracterizado pelas apropriações populares do seu espaço. No Centro Histórico (mais específico nos bairros Sé e República) uma classe média também se apropria do lugar com seus costumes, afinal, as ruas e avenidas do Centro ainda guardam suas antigas representações para esta classe: Rua Dona Maria Paula, Avenida Brigadeiro Luís Antônio, Avenida São Luís, Avenida Ipiranga, Avenida São João. A classe média do Centro de São Paulo também guarda uma relação de identidade com seus monumentos modernos: Edifício Copan, Terraço Itália, Bar Brahma, Teatro Municipal, Biblioteca Mário de Andrade, a Rua Augusta para seus jovens, a prática de subir no Minhocão (elevado Costa e Silva) aos domingos para andar de bicicleta, caminhar e correr. As Cantinas Italianas da Mooca e do Bixiga, a cena cultural às margens da Praça Roosevelt. A estratégia da cultura para a revalorização do Centro também os contém. Vila Buarque e Santa Cecília vivem indiretamente e discretamente as representações do espaço que vem dos bairros Higienópolis e Pacaembu, ao mesmo tempo em que veem, do outro lado da Avenida São

\footnotetext{
${ }^{87}$ Essas áreas estão ao longo do eixo da ferrovia e este antigo espaço industrial da Mooca que vai até a Vila Prudente, compõem um espaço estratégico, milimetricamente planejado para o devir das políticas urbanoterritoriais em São Paulo. A Operação Urbana que seria responsável por este fragmento da cidade era a Operação Urbana Mooca-Vila Carioca, que foi renomeada como Arco do Tamanduateí (uma espécie de extensão do Arco do Tietê). Ver também: http://sao-paulo.estadao.com.br/noticias/geral,haddad-espera-r-5-2-bilhoes-com-1operacao-urbana-em-sao-paulo, 1618345
} 
João, a popularização que "deprecia" (abaixa o preço) dos Campos Elíseos e suas proximidades com a estação da Luz.

Nos Campos Elíseos, na República, na Sé o uso e apropriação proletária do espaço ganham sentido e revelam a potência da necessidade, da vontade e do desejo. Nesses espaços o habitar o Centro revela formas de transgressão que desafiam a lógica capitalista da propriedade privada do solo urbano. Nos prédios vagos, as ocupações organizadas pelos movimentos sociais, a apropriação plena do espaço público pelos moradores em situação de rua que não se organizam, mas tem uma dinâmica própria, os trabalhadores do comércio informal (e suas práticas cotidianas de fuga da fiscalização), a inversão do sentido das praças através da prática do skate, a sexualidade pulsante nos lugares, os lugares das identidades de gênero que transgride o que está posto. Transgressão, transformação, transexualidade, supressão das normatividades, enfim, o Centro é também o lugar que reúne as diferenças, é o lugar que produz o diferencial e com o diferencial reproduz o espaço. O Centro guarda o resíduo da contradição positiva, aquela que deriva como direito às diferenças, o traço primordial da humanidade do homem, aquele que vem da pulsão e do desejo, do prazer e do gozo, da sua realização plena enquanto humano. Podemos dizer que no Centro há uma latência reservada nessa diversidade que potencializa alguns traços do verdadeiro direito à cidade através da apropriação plena do lugar. No Centro de São Paulo a pequeno- burguesia se mistura com o proletariado, com o diferencial, e fica próxima também daquilo que pode ser considerado como o sentido positivo de apropriação do espaço.

Nesses dois anos e meio de flâneur, "experimentando" o dia a dia do Centro de São Paulo, pude observar (talvez de maneira até superficial e imediata) que o predomínio de sua ocupação é marcado pela apropriação e uso proletário do espaço, ou seja, geralmente são os trabalhadores do comércio, das muitas empresas de serviços e escritórios que continuam no Centro, trabalhadores do comércio informal, trabalhadores da reciclagem, artistas de rua, sujeitos que fazem programa etc. Levando em consideração esta realidade, o "impasse" não estaria somente e/ou apenas na propriedade privada do solo urbano, pelo contrário, o "impasse" também está na sua forma de apropriação que revela que o uso se potencializa em relação ao valor de troca. Neste caso o valor se substancializa na prática, no ato do uso, e não naquilo que foi produzido para ser consumido por outrem. Quando consideramos que o uso aniquila a troca (pelo menos nas relações que estão postas para a reprodução do Centro de São Paulo), decorre do fato de que o espaço (socialmente e historicamente produzido), quando apropriado pela classe proletária adquire outro sentido, talvez até orgânico, em que o uso é a forma que satisfaz plenamente as necessidades deste grupo. Esses sujeitos que ocupam e 
resistem no Centro de São Paulo são sujeitos que historicamente sempre expulsos do Centro e expropriados em todos os sentidos. A condição proletária inverte o sentido do espaçomercadoria no capitalismo, já que faz com que "uma coisa pode ser útil e produto do trabalho humano sem ser mercadoria” (MARX, 2013, p. 118). Neste caso, não há produção de valor de uso para outrem, há uma relação em que a produção humana põe-se a serviço da apropriação, o que direciona a produção do valor de uso para outra esfera que não aquela da propriedade privada.

Além da dimensão econômica (ligada à produção de um novo valor de uso que é posto à venda), estes sujeitos expropriados, espoliados e pilhados historicamente mostram mais que uma dimensão política na vida cotidiana; mostram uma estética específica - estética que vem da prática da transgressão - que põe em xeque tanto a reprodução da cidade (no caso da dimensão econômica) quanto a reprodução da própria vida cotidiana. Talvez o verdadeiro "impasse" esteja no fato de que são estes os sujeitos que ocupam o Centro de São Paulo e são eles que invertem o sentido econômico de se apropriar privativamente do espaço.

A forma propriedade privada do solo, quando considerada na dimensão da cidade e do urbano faz com que estes ganhem expressões materiais específicas ${ }^{88}$ e, atrelado ao seu uso, há também o interesse dos sujeitos conforme seus interesses classe. A classificação de uso do solo $^{89}$ permite que nos aproximemos da miríade de estruturas que compõem o mosaico complexo e contraditório que é a metrópole, ainda mais levando em conta a relação totalizante entre o espaço público e o espaço privado. A classificação de uso do solo urbano revela a dimensão política que, além da fragmentação e hierarquização dos espaços, estrutura também a relação dos usos que contribuem na diferenciação dos lugares. Nesta dimensão, os níveis econômico e político se justapõem na caracterização do espaço produzido, revelando a extensão do valor de troca ao espaço através das estratégias de classe no processo de reprodução do espaço.

O Estado, para além de exercer violentamente e coercivamente sua dominação política, é também o responsável para resolver o "impasse" que a propriedade privada do solo urbano implica no processo de revalorização do Centro de São Paulo. Por um lado, com prática que, cada vez mais, se consolidam e são "naturalizadas" socialmente, como é o caso do processo de militarização. Por outro, com práticas atuais que mais se assemelham a uma

\footnotetext{
${ }^{88}$ Lote, terreno, terreno industrial, casa, apartamento, "meio lote", laje corporativa, edifício corporativo, galpão industrial, galpão logístico, estacionamento, clube de lazer privado, escola privada etc.

${ }^{89}$ Residencial (horizontal e vertical), comércio e serviços, industrial, especial (hotel, hospital, cartório etc.), escola, coletivo (cinema, teatro, clube, templo etc.), armazéns e depósitos e garagens. Neste caso, convém salientar que tal classificação é elaborada pela Prefeitura Municipal de São Paulo.
} 
empresa capitalista, por gestar administrativamente a sociedade (e a luta de classes), o Estado soluciona um problema com duas perspectivas: transferindo-o para outro lugar e, ao mesmo tempo, visando uma forma de auxiliar a atividade produtiva por meio da mudança. No caso do “impasse" no Centro de São Paulo, várias estratégias foram postas ao longo dos anos. Nesta pesquisa, para fins de explicitar a realidade de luta de classes (às vezes dissimulada e às vezes latente) que ocorre na disputa pelo Centro de São Paulo, elencamos algumas estratégias como as intervenções urbanísticas que se realizam por meio das políticas urbano-territoriais (Operação Urbana e Concessões Urbanísticas), como também a estratégia política de revalorizar o Centro sob a justificativa da cultura. Em ambas, aniquilar o valor de uso do espaço é expulsar todos que fazem do Centro um lugar de apropriação popular para a realização da vida, contudo, uma é de caráter direto de formas de apropriação e a outra tem o mesmo objetivo de valorizar através de um referencial estético e cultural.

No movimento de reprodução do Centro de São Paulo em que, na atualidade, a revalorização se torna um processo de auferir novo valor de uso para o espaço que foi (e é) socialmente e historicamente produzido, a propriedade privada do solo urbano compreende a forma de propriedade privada que é central para a compreensão da reprodução capitalista do espaço. Levando em conta a implosão do Centro de São Paulo - neste caso as transformações que derivam do acumulo histórico de tudo que caracteriza o espaço do Centro - como também sua contradição fundante, àquela da raridade do espaço, a propriedade privada do solo urbano (superedificado, hiperadensado e completamente marcado pelos excessos advindos do processo de urbanização ao longo do século XX) também pode ser considerada nos termos do que também chamados de propriedade privada do espaço; neste caso, do espaço socialmente e historicamente construído. Aliás, o sentido de atribuir o "historicamente" atrelado ao social, deriva do fato de que os conflitos atuais apenas se realizam enquanto resultado de um processo histórico, nesse caso, o próprio processo de urbanização.

As condições históricas da consolidação do capitalismo industrial que explodiu a metrópole, foram as mesmas condições que separaram as classes sociais no espaço, lançaram o proletariado nas periferias e extremos da metrópole e o privaram da própria cidade e da vida urbana. A transição do período em que havia o predomínio da atividade produtiva ligada à indústria de transformação para o período em que há o predomínio do setor financeiro e de serviços avançados, caracteriza também uma mudança no perfil dos assalariados, dos consumidores e, por conseguinte, da própria configuração das classes sociais. A reprodução interrupta da metrópole, conforme o movimento do capitalismo enquanto modo de produção, foi também a reprodução das classes sociais, cuja Geografia deriva dessas próprias condições 
da reprodução social. O movimento totalizante de toda reprodução revela as redefinições que são históricas e que somente ganham materialidade significativa, ainda mais em termos de conflito, quando o movimento da história se realiza por meio do espaço socialmente produzido. Assim, a propriedade privada do solo urbano exige sua interpretação enquanto forma capitalista - portanto, forma de apropriação privada do algo - que centraliza em si condições que asseguram os limites da reprodução do regime de acumulação.

Portanto, quando consideramos esta centralidade atribuída à propriedade privada do espaço sob os desígnios da forma de produção que se realiza no capitalismo (em que predominantemente há o movimento contínuo da produção de novos valores de uso para serem postos à venda no mercado) é pelo fato de que esta é a forma que, sob o imperativo do valor de troca (portanto, sob o imperativo da sua produção enquanto produção de um novo valor de uso que está à venda), segrega, aparta, separa e distancia, cada vez mais, os indivíduos da possibilidade de realização da vida urbana. Ao mesmo tempo em que ela se realiza sob o fundamento do valor de troca, asseverando cada vez mais a forma-mercadoria e sua extensão ao espaço urbano, a propriedade privada do espaço permite também o surgimento de práticas socioespaciais de resistência, ligadas às formas de transgressão que iluminam, ou pelo menos apontam, o direito à cidade como uma forma de superação das condições atuais.

A propriedade privada do espaço, sob os imperativos do valor de troca e as determinações da forma-mercadoria, constitui-se enquanto um crivo, ou seja, uma espécie de "filtro de seleção" dos indivíduos que serão integrados à vida urbana que está posta para o Centro, ligada à cultura e a possibilidade de ocupação de uma fração pequeno-burguesa da sociedade. Enquanto forma atravessada pelas determinações e controle do Estado, a propriedade privada do espaço torna-se também uma espécie de elo da disputa pelo espaço. Para por em movimento o processo de produção capitalista do espaço, o Estado passa a ser a instituição (portadora da violência) que desapropria, quando exige (por meio de recompensa) a saída dos indivíduos de suas casas e/ou outras edificações; e também expropria, quando, por meio da forma burguesa e da condição determinativa da propriedade privada (neste caso, do espaço construído), exige que os sujeitos em estágio de apropriação desocupem suas unidades para que estas voltem para o domínio do proprietário instituído por lei. Assim, enquanto forma que estritamente é posta sob as determinações do valor de troca, a propriedade privada do espaço tem suas garantias todas asseguradas pelo Estado, porém, enquanto forma que se realiza sob a primazia do valor de uso, e consequentemente tornada um "impasse" para o circuito do capital, a propriedade privada do espaço é a forma que passa por uma espécie de 
liberação atribuída pelo Estado. Ao ser liberada, a propriedade privada do espaço torna-se a forma que permite transformações em sua estrutura e sua função, capazes de adequar aos novos valores que serão produzidos.

No âmbito da reprodução do Centro de São Paulo, a propriedade privada do solo urbano, quando atravessada pelas estratégias de dominação do Estado, revela as formas de intervenção no espaço que insere esta forma de propriedade no movimento que caracteriza novas formas de propriedade, neste caso, a propriedade privada do espaço. Mais do que a unidade edificada, mais do que a unidade de fragmento do espaço que permite a edificação (a figura do terreno urbano ou do lote), a propriedade privada do espaço (ou mesmo uma unidade privativa do espaço) é a forma que, atualmente, se valoriza - ou como é o caso do Centro de São Paulo, se revaloriza - por meio de novas representações e valores de uso que são atribuídos à sua forma, e que somente se realizam enquanto um resultado que deriva do espaço socialmente produzido e da materialidade imediata do lugar. Enquanto a reprodução do Centro se realiza pela sinergia entre Estado e iniciativa privada, por meio de estratégias que visam reverter a contradição posta da raridade do espaço, o processo de revalorização enquanto artifício estratégico que aufere ao espaço novas representações e novos valores de uso - torna-se uma prática do Estado e da iniciativa privada, que somente se realiza enquanto processo de reprodução. Assim, reprodução e revalorização se compõem enquanto duas esferas complementares do mesmo processo que ocorre no Centro de São Paulo.

Além dessas duas esferas que se complementam (Estado e capital) a reprodução do Centro também é caracterizada por duas frentes: uma específica às medidas de intervenção nos distritos Sé e República - portanto, aqueles mais caracterizados pelo fenômeno da raridade do espaço - e outra direcionada à ampliação dessas estratégias de revalorização para os distritos que ficam no entorno dos distritos Sé e República, através de uma espécie de aproveitamento estratégico das suas potencialidades que podem complementar as ideologias ligadas à cultura que caracterizam o Centro. A transição das intervenções pontuais (aquelas ligadas às reformas e manutenção de patrimônios arquitetônicos e históricos) adquire uma espécie de movimento de superação, ao serem também caracterizadas no conjunto das medidas e intervenções que estão inscritas nos territórios estratégicos. O Plano Diretor de 2014 parece explicitar bem esta dimensão, ainda mais quando delimita os chamados Territórios de Interesse da Cultura e da Paisagem (TICP), sendo o primeiro correspondente a um perímetro formado entre a Avenida Paulista e a Luz.

A propriedade privada do espaço guarda uma centralidade no processo de reprodução do Centro de São Paulo, afinal, os conteúdos das novas representações e do novo valor de uso 
atribuídos ao espaço recaem nesta forma de propriedade. Para a revalorização do Centro de São Paulo, o Estado elabora políticas e delimita territórios estratégicos para a intervenção no espaço, e, por meio de seu poder de dominação, põe em suspensão (até o momento em que esta fique liberada) a propriedade privada do solo urbano, para depois retorná-la às suas condições sociais "naturalizadas" no capitalismo. Superedificado, pulverizado, hiperconcentrado e marcado pelos excessos do processo de urbanização, o Centro de São Paulo, através da contradição entre abundância e raridade do espaço, revela o próprio limite para sua própria reprodução. A saída, que também é uma saída para que a propriedade privada do espaço entre novamente no circuito do capital, foi tombar esta estrutura superedificada por meio da preservação da paisagem, o que exige apenas sua reforma e manutenção e, por conseguinte, sua revalorização. Além do mais, as expectativas da indústria do imobiliário no Centro de São Paulo também passaram a se concentrar no seu entorno, principalmente naqueles distritos marcados pela concentração de estruturas, infraestruturas e equipamentos urbanos e que estão, literalmente, do lado dos distritos Sé e República, como é o caso dos distritos do Bom Retiro, Pari e Brás que vem passando por significativos crescimentos no que tange aos lançamentos imobiliários.

Ao garantir as políticas e estratégias de intervenção no espaço, o Estado garante também as possibilidades de assegurar para este fragmento da metrópole a tendência de se realizar enquanto uma nova fronteira de acumulação. Numa análise minuciosa da realidade inerente ao Centro de São Paulo, podemos perceber que na propriedade privada do espaço são atravessadas as relações (inerentes à reprodução da metrópole) caracterizadas pelo Estado, pelo capital e pelos respectivos interesses dos sujeitos que veem na propriedade privada do espaço as possibilidades e anseios de realização das suas respectivas vidas. 


\section{Capítulo III}

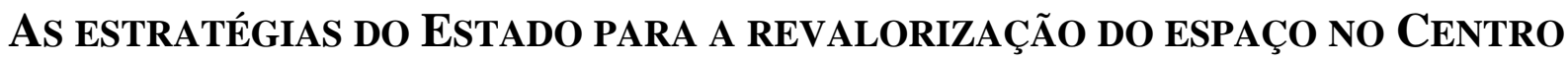 de São Paulo}

A relação entre Estado e espaço, no que tange ao desenvolvimento das normas (leis e decretos) que conduzem o processo de urbanização, revela uma sinergia técnica entre estas duas dimensões da realidade que, no âmbito da reprodutibilidade, se metamorfoseiam em dimensões necessárias ao processo de reprodução.

A dimensão estratégica que deriva das ações do Estado se consubstancia através dos planos de intervenção (Plano Diretor, Plano Regional, Lei de Parcelamento, Uso e Ocupação do Solo, Plano Plurianual etc.) que, ao serem caracterizados atualmente por políticas que são postas em prática através de territórios específicos, revelam a amplitude e a finalidade dessas estratégias contidas no chamado ordenamento territorial. As políticas e as determinações postas para o Centro de São Paulo se articulam de maneira com que haja complementaridade entre elas, em que uma se realize na outra. Ao mesmo tempo, a continuidade torna-se um fator essencial, afinal, com o fim de uma política de intervenção (como foi o caso do PROCENTRO) há também a continuidade de seus objetivos em outra, como é o caso da Operação Urbana Centro ou mesmo as estratégias de intervenção atuais (como é o caso do “Arco do Tietê").

Assim, ao controlar o conjunto, hierarquizar os lugares por meio dessas políticas, e ainda "quebrar", no sentido de desmobilizar e enfraquecer, as oposições de resistência ao processo de revalorização (quando permite que a reforma total dos edifícios, o Retrofit Total $^{90}$, possa se constituir como uma frente de desmobilização dos movimentos de moradia no Centro), o Estado põe em prática uma série de ações que tende a abrir um novo nicho de acumulação. A modificação do Código de Obras e Edificações, para permitir o Retrofit Total, faz com que estes novos serviços de reforma das estruturas arquitetônicas tornadas patrimônio produzam, sob o álibi da cultura, uma nova frente de produção que se constitua como um álibi de intervenção nos prédios ocupados do Centro de São Paulo.

Na atualidade as políticas de intervenção no espaço direcionadas para o Centro de São Paulo correspondem não mais apenas os distritos Sé e República, passando também a incluir os distritos adjacentes ao nó central, formando uma espécie de centro expandido. No Plano

\footnotetext{
90 Conforme a $18^{\mathrm{a}}$ diretriz do artigo 27 do PDE 2014 que visa estimular a reabilitação do patrimônio arquitetônico, especialmente na área central, criando regras e parâmetros que facilitem a reciclagem e Retrofit das edificações para novos usos.
} 
diretor estratégico aprovado em 2014, o território da Operação Urbana Centro (e entorno) constitui um dos três setores que referenciam as intervenções (mapa na página 134).

As mudanças previstas em plano e que direcionarão as intervenções no chamado de Setor Central, ocorreram após anos de intervenções pontuais nestes distritos que compõem a área central. Atualmente, a delimitação estratégica de territórios para intervenção, como também o perfil das intervenções postas para os distritos onde ocorre a escassez de espaço, caracterizam duas perspectivas que tendem a tomar impulso para direcionar duas frentes de atuação: a primeira relacionada ao mercado de Retrofit de imóveis, que poderá se apropriar, preferencialmente, dos imóveis que constituem a zona especial de preservação cultural de bens de imóveis representativos; a segunda correspondente ao entorno da operação urbana centro, por meio da "requalificação e reabilitação das áreas deterioradas e subutilizadas", ocupadas de modo precário pela população de baixa renda, como cortiços, porões, quitinetes e moradias similares, em bairros como Glicério, Cambuci, Liberdade, Pari, Canindé, Brás, entre outros $^{91}$.

Levando em consideração estes fatores, a sequência da exposição é caracterizada por uma explanação do que entendemos como políticas urbano-territoriais para que, em seguida, possa ser caracterizados seu movimento de constituição ao longo da história para fins de compreender como que, na contemporaneidade, estas políticas promovem a homogeneização dos espaços em escala mundial. Após esta exposição introdutória, elaboramos uma exposição dos conteúdos das políticas de intervenção no Centro de São Paulo, tanto aquela que já encerrou suas atividades, como é o caso do PROCENTRO, quanto aquela que, apesar de ter sido toda elaborada e já estar em fase de início, acabou sendo embargada, o caso da concessão urbanística Projeto "Nova Luz"; há também aquela que está em plena atividade, contudo, passará por revisões, como é o caso da Operação Urbana Centro. Além desta, como política atual, elencamos também as intervenções que estão postas sob a responsabilidade do Estado de São Paulo, na figura da PPP Casa Paulista Área Central. Considerando também o andamento das propostas e o desenvolvimento da política, fez-se de grande importância tecer algumas considerações sobre o chamado "Arco do Tietê".

Além das políticas de intervenção no espaço que se realizam por meio de territórios delimitados estrategicamente, há também as considerações voltadas às estratégias ligadas a cultura. No processo de revalorização do Centro de São Paulo, a cultura torna-se o

\footnotetext{
${ }^{91}$ SÃO PAULO (Município). Objetivo $5^{\circ}$ do artigo $3^{\text {a }}$ da Lei no 16.050 , de 31 de Julho de 2014 que Aprova a Política de Desenvolvimento Urbano e o Plano Diretor Estratégico do Município de São Paulo e revoga a Lei ${ }^{\circ}$ 13.430/2002.
} 
componente estratégico que complementa as intervenções no espaço através das políticas que estão postas. Na relação de complementaridade entre as políticas urbano-territoriais e a cultura, estas, por sua vez, fundamentam o momento em que a transformação estética do espaço se realiza através da reforma das estruturas arquitetônicas, compondo assim um encadeamento de realizações e intervenções. Neste caso, destacamos a metamorfose sofrida pelo patrimônio histórico, enquanto uma transformação que visa revalorizar o espaço. Há ainda, atualmente, alguns conteúdos ligados à cultura, compondo uma espécie de extensão desta justificativa de intervenção através da chamada economia criativa e mesmo a prática econômica do turismo.

Atualmente, na impossibilidade de reverter a escassez do espaço, as estratégias políticas para as intervenções no Centro de São Paulo passam a se realizar por algumas frentes: a) nos distritos Sé e República e nos lugares do Centro onde o espaço torna-se raro, através do tombamento de bens de imóveis representativos que servirá de álibi para a prática de reforma total dos edifícios; b) ao estender para o entorno dos distritos Sé e República o conjunto das políticas que são atribuídas ao Centro de São Paulo, naquilo que consideram Setor Central; c) ao desenvolver estratégias ligadas à cultura que tendem a se articular com as intervenções e políticas delimitadas por territórios estratégicos; d) produzindo alguns mecanismos que auxiliam no processo de segregação socioespacial a partir do momento em que promovem e auxiliam na produção dos produtos imobiliários residenciais voltados para um perfil específico de consumidor.

\subsection{AS POLÍTICAS URBANO-TERRITORIAIS NO MOVIMENTO DA REPRODUÇÃO DO CENTRO DE SÃo Paulo}

As políticas territoriais tem como referência a delimitação estratégica de territórios posta em prática pelo Estado e apresenta como ponto de partida as intervenções que ocorreram após a década de 1990. A análise das políticas urbano-territoriais no Centro da metrópole de São Paulo (assim como seu entorno) é composta pelo histórico e a proposição das políticas ao longo dos anos, em que destaca o espaço instrumental, institucional e burocrático do Estado por meio da articulação dos tempos das estratégias no espaço.

As políticas urbano-territoriais revelam uma dimensão estratégica do Estado no tocante às estratégias que foram (e são) postas em torno do processo de revalorização do Centro de São Paulo. Representando a esfera de domínio do Estado, ainda mais quando consideramos a razão instrumental que efetiva as ações neste domínio, estas políticas revelam o espaço enquanto fator estratégico e, ao mesmo tempo, condição e meio ao movimento da 
reprodução. Assim, este termo, políticas urbano-territoriais, implica, de certa forma, um ponto de destaque na exposição desta dissertação. Como uma maneira de se situar no debate e, ao mesmo tempo, na contramão dos conteúdos empregados acerca da noção de políticas públicas, a razão expositiva sobre o termo tem como premissa duas dimensões da realidade: primeiro, apresentar o caráter técnico e instrumental desta dimensão política, em que o domínio do Estado se figura através do espaço; segundo, destacar como este mecanismo de intervenção contém, e ao mesmo tempo contempla, a centralidade do Estado no processo de reprodução capitalista da metrópole. Dessa maneira, estas considerações sobre as políticas urbano-territoriais constituem-se como um posicionamento frente à realidade técnicoinstrumental posta em prática pelo Estado. Assim, a exposição desta dimensão, técnica e ao mesmo tempo estratégica, se realiza por meio da elaboração de um argumento que parte da relação entre a forma política que é característica ao Estado (e às suas atribuições) e a formamercadoria, neste caso, caracterizada tanto pela sua extensão ao espaço quanto pela sua influência à forma política.

Em relação às políticas urbano-territoriais, estas são compreendidas a partir das intervenções do Estado no espaço da cidade, por meio da delimitação de territórios necessariamente estratégicos. Nestes territórios, a estratégia imposta é aquela do Estado que, ao delimitar, não o faz de maneira aleatória, mas sim sob fins específicos geralmente ligados à reprodução do espaço. Carlos (2001), levando em conta as estratégias do Estado, destaca que a interferência deste ocorre no sentido de redefinir os limites da propriedade privada do solo, sinalizando as novas (e já consolidadas) relações do processo de reprodução espacial. No caso da exposição da autora, o que está em evidência é a operação urbana, contudo, além deste instrumento urbanístico para intervenção no espaço, no caso do Centro de São Paulo destacamos também a presença da Concessão Urbanística e da Parceria Público Privada para a construção de habitações (este no âmbito do Governo do Estado de São Paulo). Assim, Operação Urbana, Concessão Urbanística e Parcerias Público Privadas (neste caso, para as habitações) constituem o conjuntos das políticas que, ao delimitarem territórios estratégicos, evidenciam a (e, ao mesmo tempo, nos auxiliam na) compreensão dos interesses que estão por trás de uma luta que cada vez mais se torna expressiva.

A escolha de algum fragmento específico da metrópole qual irá passar pelo processo de intervenção, como também a delimitação de um território específico neste fragmento escolhido, não é uma ação do Estado que ocorre de maneira aleatória. Conforme assinala Lefebvre (1976), quando o território engendra o Estado, consequentemente, o Estado também engendra o território através das determinações que estão postas. Porém, ao engendrar o 
território por meio destas determinações postas e por ações estratégicas específicas, o Estado, consequentemente, produz também o espaço. Aparentemente, a impressão que se tem dessa relação é que o território precede o espaço, porém, isso ocorre somente na aparência. $\mathrm{Na}$ essência, o que ocorre é que o Estado, enquanto forma que se realiza politicamente, domina e concilia o espaço socialmente produzido. O domínio do espaço se expressa nas diversas formas de intervenções e transformações do espaço que são atribuídos ao Estado, enquanto que a conciliação (que também se torna uma dimensão do espaço) passa a ser também uma forma em que ocorrem as relações postas pelo Estado, na esfera da conciliação das classes sociais. Por meio das formas de dominação e levando em conta o domínio do espaço para a continuidade do processo de urbanização, insisto em destacar, mais uma vez, a importância de se levam em conta o processo de militarização. Neste caso, para além da possível conciliação de classes, a militarização do processo de urbanização - ainda mais quando levamos em conta a realidade do Centro de São Paulo - revela uma faceta da dominação mais ligada às formas de impossibilitar práticas de transgressão e resistência (bem como reverter estas condições quando já estão em ocorrência), e, consequentemente, desmobilizar as frentes populares que atual na luta pela moradia.

Além de um engendrar o outro (o Estado engendra o espaço, ao mesmo tempo em que o espaço também engendra o Estado), um se realiza no outro. Daí o fato de que o Estado produz um espaço estratégico. Podemos compreender este como o primeiro momento ${ }^{92}$ em que o território surge na e para a forma-Estado. $O$ segundo momento ${ }^{93}$ desta relação compreende o momento (ou um dos momentos) da produção do espaço, tanto através do movimento quanto em processo. O território, no processo de produção do espaço, se realiza ${ }^{94}$ no momento da própria produção e é parte constitutiva e necessária da estratégia que transforma o espaço socialmente produzido em meio e condição da produção. Nesse caso, a delimitação estratégica de um território ${ }^{95}$ para fins específicos, ocorre em função das próprias práticas de intervenção no espaço onde praticamente tudo é posto em suspensão ${ }^{96}$ para a realização do "bem comum". Este é o momento em que a "racionalidade" do Estado entra em operação e, por meio de uma instrumentalidade e operacionalidade que lhe é peculiar, delimita territórios que impõem de imediato sua dominação e sua violência. A suspensão da

\footnotetext{
${ }^{92} \mathrm{O}$ Estado se realizando e sendo realizado no território.

${ }^{93}$ Quando o Estado para realizar sua dominação, impor e fazer valer o conjunto das normas, leis e contrato social delimita e recorta o espaço sob determinações específicas.

94 Nesse caso, a realização do território ocorre enquanto estrutura que porta em sua forma uma função determinada em um contexto de política de intervenção no espaço urbano.

${ }_{95}^{95}$ Portanto, materializado e encravado no espaço enquanto forma de território.

${ }^{96}$ Inclusive e especialmente a propriedade privada do solo urbano.
} 
propriedade privada do solo urbano, neste caso, é apenas uma espécie de modificação que restaura a forma para fins de conservar a contradição (entre uso e troca, e apropriação e dominação).

A delimitação estratégica dos territórios, para efeito das políticas do Estado, consiste numa espécie de mecanismo com determinações específicas à reprodução do espaço. Neste fragmento da metrópole a delimitação estratégica de territórios de intervenção revela, na verdade, a problemática inerente ao Centro de São Paulo em que o interesse antagônico das classes sociais pelo espaço expõe um conflito que também se realiza por meio da dimensão do Estado. Por coadunar com os interesses da burguesia e, por conseguinte, do capital, o Estado põe em prática uma série de ações (geralmente que visa conciliar o conflito entre as classes sociais) que, entre elas, derivam também territórios de intervenção política no espaço. Neste caso, o território surge de um processo conflitivo, como assevera (HAESBAERT, 2009, p. 107)

mais até do que traduzir "o que é" ou o "ser" do território, trata-se de discutir seu devir, isto é, em que problemática nos envolvemos e o que efetivamente fazemos ao acionarmos e/ou ao produzirmos nossas concepções de território - sempre em aberto, portanto, para sua própria reavaliação/renovação.

Neste sentido, talvez para aquém ou além de discutir o devir, o que está posto nesta pesquisa é como esta delimitação estratégica de territórios de intervenção no espaço, realizada através do Estado, assemelha-se mais a um mecanismo de intervenção no espaço que permite à manutenção das formas necessárias a própria reprodução capitalista do espaço. Levando em conta que a dimensão essencial para a reprodução do capital está na continuidade da realização da forma-mercadoria e, por conseguinte, na continuidade do valor de troca, o espaço (ainda mais no Centro de São Paulo ocupado e marcado pela intensificação da sua ocupação proletária), em sua reprodução, se realiza sob a primazia do valor de troca que sufoca o valor de uso, as formas de apropriação e, até mesmo, o seu uso. A condição e interesse em realização deste último, apenas ocorre em função do valor de uso ser forma recorrente e, ao mesmo tempo, necessária à reprodução das relações sociais que ocorrem na metrópole. Levando em conta este fator, em que uso e troca são atravessados por um valor que apenas se constitui no seio das relações sociais; e somando-o ao fato de que, enquanto fator, este apenas se realiza em sua dimensão espacial, cabe ao Estado - por meio das políticas urbano-territoriais - reverter o conflito, porém, sem eliminar as contradições que o funda. 
Ainda sobre a relação entre os territórios e o processo de acumulação, Robira (2005) discorre sobre o processo de metropolização a partir daquilo que considera como territóriosreserva. Levando em conta que os espaços metropolitanos permitem ao longo do tempo a realização de uma forma de acumulação capaz de transformar em escassos alguns bens, a autora afirma que a acumulação de escassez alimenta e sustenta aquilo que considerou como processo de colonização ${ }^{97}$, capitalização e metropolização do território. Segundo as considerações da autora, conforme há este processo progressivo de metropolização, há também o acúmulo de déficits sociais e urbanos que faz com que alguns espaços da metrópole, em uma lógica de valorização diferenciada, se tornem territórios-reservas e/ou reservas urbanas.

Por mais que nosso argumento nesta dissertação tenha como referência a delimitação estratégica de territórios para que as políticas públicas diretamente relacionadas a reprodução do espaço possam surtir enquanto formas que coadunam com o desenvolvimento do espaçomercadoria, este diálogo com Rosa Tello Robira torna-se importante do ponto de vista de pontuar algumas diferenças naquilo que observamos neste processo de revalorização do espaço no Centro da metrópole paulistana. Enquanto nosso fundamento de argumentação é a teoria do valor que norteia o desenvolvimento da mercadoria n’O Capital de Marx, para Rosa Tello Robira, a base da sua argumentação são os territórios metropolitanos. Para a autora, estes territórios permitem aquilo que ela considera como processos moleculares de acumulação de capital em que a continuidade da produção da acumulação são mantidas por territórios que mantém no seu interior "territórios não-capitalistas". Ao longo do texto, salvaguardo a possibilidade de equívocos de nossa avaliação, Robira tece algumas relações entre o território e suas possíveis escalas; neste caso, na escala metropolitana, como aquela que permite a realização da acumulação em função da produção das formas de escassez e, na escala da intervenção (portanto, naquilo que a autora considerou como interior do território metropolitano), levando em conta aquilo que considera como territórios "não-capitalistas".

No caso desta pesquisa, a noção de território somente ganha materialidade através da delimitação do perímetro das intervenções urbanas. Políticas Públicas, Estado e a delimitação

\footnotetext{
${ }^{97}$ Para (ROBIRA, 2005, p.14-16), o processo de metropolização se realiza igual ao processo de colonização. Para autora, dois referenciais norteiam este movimento de pensamento. Primeiro enquanto um processo de acumulação primitiva, por meio da produção de enormes déficits urbanísticos e diferenças sociais, e, depois, como reservas de solo urbano e força de trabalho em que conforme há o processo de crescimento demográfico e expansão urbana, servem como reservas que de certa forma mantém o processo de acumulação. Para Rosa Tello Robira, é neste processo de expansão da cidade que há o processo de colonização do território em que a acumulação primitiva impõe uma subordinação urbana ao entorno de maneira a organizar o processo de metropolização do território.
} 
estratégica de um fragmento da metrópole tornam-se peças-chave para a compreensão e avaliação do movimento histórico destas políticas e a relação direta destas com o processo de reprodução da metrópole. De forma diferenciada de Robira, que avalia os territórios nãocapitalistas como territórios não-metropolitanos ou territórios adormecidos, ao localizar a metrópole (e consequentemente o espaço urbano) enquanto fundamento de realização e manutenção da vida, o que emerge de imediato no debate é o fundamento do valor de uso enquanto potência em latência que, a todo momento conduz as relações sociais que inexoravelmente tendem à reprodução da metrópole. Se a primazia do valor de troca (que garante a reprodutibilidade da forma mercadoria inclusive por meio da produção do espaço) é posta em xeque pelos fundamentos do uso ${ }^{98}$, isto, levando em conta o processo de urbanização e a disputa classista pelos resultados deste processo, expressa uma dimensão da luta de classes que, atualmente, ganha expressividade ou mesmo novas características na atualização da problemática urbana. Se para Robira é o processo de metropolização que caracteriza uma forma de território e esta, por sua vez, é diferencialmente determinada por fragmentos (ou territórios na acepção da autora) capitalistas ou não-capitalistas (e/ou adormecidos), em nossa avaliação, o território estrategicamente delimitado que põem em suspensão uma série de formas preponderantes à reprodução capitalista do espaço e da metrópole - principalmente a propriedade privada do solo urbano - é que direciona os rumos do processo de revalorização em sinergia com a iniciativa privada.

Contudo, de forma alguma há a invalidação de uma ou outra forma de avaliação. Pelo contrário, há uma proximidade muito grande das duas frentes de avaliação do mesmo processo. Para Robira, aquilo que foi considerado como "territórios adormecidos" ou "territórios não-capitalistas" deriva da condição de subprodutos do processo de acumulação territorial que levou à territorialização metropolitana ${ }^{99}$. No caso desta pesquisa, avaliamos como espaço desvalorizado aquele em que a centralidade urbana não se realiza mais em sua

\footnotetext{
${ }^{98}$ Sobretudo nas formas de sociabilidade capitalistas em que o uso permite a realização da forma valor que tende a exprime em direção ao valor de troca.

${ }^{99}$ Os espaços metropolitanos poderiam ser caracterizados como aqueles que acumulam e dispõem da maior capacidade para transformar em bens escassos elementos necessários para a condição "natural" de vida dos cidadãos: água potável, ar respirável, mobilidade fluída, espaço doméstico, silêncio e tranquilidade, tempo pessoal disponível...; e se pode dizer que essa acumulação de escassez de condições "naturais" básicas alimenta e sustenta o processo de colonização, capitalização, ou metropolização do território. Esses efeitos da territorialização metropolitana do capital manifestam-se de forma diferencial no espaço urbano: quanto maior é a escassez desses bens acumulada em determinados fragmentos do território metropolitano, maior é a não capitalização espacial, ou seja, em palavras simples, maior é a diferença socioespacial, ou utilizando o conceito de espacialidade de Milton Santos, maior é seu gradiente diferencial de espacialidade. Esse tipo de espaço constitui os territórios-reserva que social e economicamente alimentam circuitos de "acumulação molecular do capital" e, ao mesmo tempo, são os espaços que em um momento ou em outro serão afetados por intensos processos de reforma urbana derivados das crises de superacumulação de capital no sistema produtivo metropolitano (ROBIRA, 2005, p. 16-17).
} 
plenitude, ou seja, aquele fragmento da metrópole que foi provido de centralidade significativa e, ao longo do tempo, conforme se desdobrou o processo de urbanização e/ou metropolização, novas centralidades surgiram para dar conta das necessidades inerentes ao período de acumulação. É neste sentido que a tríade valorização-desvalorização-revalorização norteia nosso pensamento para avaliar as condições atuais do processo de reprodução da metrópole e da revalorização do Centro de São Paulo. No processo de revalorização atual, a delimitação estratégica de territórios de intervenção configura-se no procedimento posto em prática pelo Estado que adquire significativa importância.

Um ponto em destaque deve ser salientado neste momento: o que ocorre é a delimitação de territórios para fins de intervenção no espaço urbano socialmente e historicamente produzido. Este processo (ou mesmo procedimento) não diz respeito à criação de territórios, ou mesmo territorialização das políticas públicas, ou ainda a uma representação política a partir de um território. A delimitação de territórios estritamente específicos para a intervenção no espaço revela as estratégias empreendidas pelo Estado (e somente passível de realização por este) em que o espaço historicamente e socialmente produzido passa a ser o referencial de mediação entre o capital, o Estado, a reprodução (que contém o processo de produção do espaço) e as lutas de classes. A delimitação estratégica de territórios de intervenção no espaço urbano, neste caso, revela os mecanismos que dão cabo no processo de urbanização capitalista, capazes de reverter até mesmo uma condição de primazia (a do valor de uso) para a condição que é necessária ao capital (a do valor de troca).

A suspensão da propriedade privada do solo urbano (ou propriedade privada do espaço), se constitui por meio da ação do Estado, através de um movimento de superação de uma condição dada ${ }^{100}$, portanto, que já se realiza, por meio da suspensão de uma forma social (a propriedade privada) que é intrínseca e necessária à forma de reprodução a qual está determinada. O momento da suspensão da propriedade priva do espaço é aquele em que a contradição entre produção social e apropriação privada é conservada; contudo, é também o momento em que a identidade da forma (propriedade privada do solo urbano) é restaurada ${ }^{101}$.

\footnotetext{
100 Neste caso, caracterizada e marcada pela primazia do valor de uso conferido ao espaço, ou seja, onde, tendencialmente, o movimento que ocorre é aquele que vai em direção, cada vez mais, das formas de apropriação do espaço.

101 Isto que estamos considerando como o restauro da propriedade privada do solo urbano, para fins de manutenção desta forma atrelada às relações comerciais de compra e venda, se realiza a partir de formas que desarticulam e desmobilizam o uso da propriedade. Seria o equivalente a uma espécie de roubo, ou seja, uma característica espoliativa em que por meio de formas institucionais e legais, há uma apropriação do valor que está relacionado ao uso, portanto, que deriva desta forma explícita às condições de manutenção da vida na cidade. Levando em conta o valor que deriva dessas condições de uso, bem como de sua apropriação, o que resta então é a sua conversão, portanto, sua metamorfose a partir da produção de novas condições que o permita
} 
Ou seja, o papel desempenhado pelo Estado, através dos mecanismos das políticas urbanoterritoriais, nada mais é do que a produção (neste caso política) de uma nova forma de determinação para a propriedade privada do espaço. Ao liberar a propriedade privada do espaço para o mercado imobiliário, o que o Estado faz é garantir as condições para que a continuidade do processo de acumulação seja realizada a partir desta forma de produção. Assim, ao restaurar a forma da propriedade privada do espaço no momento da sua produçãoreprodução, o Estado: a) atualiza a continuidade da forma; b) atualiza a reprodução capitalista da forma; c) atualiza a continuidade das negações que são determinadas por esta forma (neste caso as lutas pelo espaço); d) atualiza a segregação socioespacial; e) atualiza as representações do espaço neste movimento capitalista de sua reprodução.

$\mathrm{Na}$ atualidade, as intervenções no espaço urbano da metrópole revelam tanto as estratégias (ainda mais aquelas vinculadas ao Estado) quanto os mecanismos por qual o espaço torna-se politicamente produzido. O movimento histórico dessas estratégias no Centro de São Paulo, revela o papel do Estado na elaboração das políticas em que a reprodução do espaço exprime o conflito entre as classes sociais que surgem neste processo. O Estado, imbuído da dimensão do planejamento e da estratégia espacial, revela a expressiva dimensão atual do processo produtivo que se realiza na produção do espaço da cidade e do urbano ${ }^{102}$. A exploração planejada da terra ${ }^{103}$, mais do que nunca, passa a ser também a exploração planejada do espaço, já que este passa a ser um meio de produção socialmente explorado, fazendo com que a expropriação dos proprietários privados assuma uma nova forma. $\mathrm{Na}$ reprodução do Centro de São Paulo ${ }^{104}$ (assim como também os distritos do seu entorno imediato), a propriedade privada do espaço (superedificado, concentrado e acentuado) se transformou em um entrave à sua própria reprodução, tornando-se, contraditoriamente, incompatível à forma-mercadoria. As políticas urbano-territoriais são apresentadas como o mecanismo que, literalmente, arrebenta este entrave para, assim, dar lugar a propriedade privada capitalista do espaço. Este processo, atravessado por interesses e formas de expropriação, revela também o conflito entre as classes derivado das condições materiais da própria vida do proletariado.

realizar, então, em valor de troca. A produção de novas condições atua diretamente no desejo de novas pessoas que estariam dispostas a pagar pelo preço do espaço e terem suas respectivas vidas transcorridas no Centro de São Paulo.

${ }^{102}$ Fato que permite nossa afirmação contínua nesta dissertação em que, somente no período em que há produção do espaço, a cidade (espaço socialmente e historicamente produzido) torna-se, além de capital fixo, também força-produtiva.

103 Marx, 2013, p. 832.

${ }^{104}$ Neste caso compreendendo os distritos Sé e República. 
Assim, a realidade torna-se o eixo norteador que permite-nos compreender como que os processos e as novas formas de produção explicitam os conflitos; e como que também o espaço ganha notoriedade enquanto condição, meio e produto para a reprodução capitalista da metrópole. Neste contexto em que o Centro (compreendido nos distritos Sé e República) e o seu entorno imediato, passam tanto pelo processo de revalorização quanto pelo processo de reprodução ${ }^{105}$, as políticas urbano-territoriais revelam as estratégias postas pelo Estado naquilo que está posto como tendência para este fragmento da metrópole. O Estado, além de pôr em prática tais mecanismos, também os articula conforme os planos estratégicos, fragmentados, tal como está o espaço, determinando tanto o espaço quanto a condição de vida do proletariado que o ocupa. Por mais que seja um mecanismo instrumental e estratégico de intervenção no espaço, estas políticas urbano-territoriais revelam uma dimensão do conflito que, inexoravelmente, deve passar pelo Estado.

A delimitação de territórios, como um mecanismo instrumental desenvolvido pelo Estado para a produção política do espaço, revela um caráter específico e estratégico do Estado ao recortar o espaço para por em prática suas formas de dominação. Articuladas aos planos que "dirigem" o processo de urbanização - plano diretor estratégico, plano regional estratégico, Lei de Parcelamento, Uso e Ocupação do Solo, como também a Lei Orgânica do Município $^{106}$ - estas políticas urbano-territoriais se revelam também na articulação e hierarquização entre as normas que tornam "técnica" as ações e práticas do Estado. Nestas práticas do Estado, o instrumental jurídico se realiza em sinergia com o instrumental operativo, portanto, de forma cooperada em que a existência de um se realiza na existência de outro. Evidente que nem todas as normas tornam-se lógicas entre si nos seus objetos, ainda mais levando em conta que o processo de urbanização é algo que se realiza em movimento. Contudo, por mais que seja impossível essa relação lógica entre as normas, cabe ao Estado, então, promover uma coerência formal entre essas normas, imprimindo de vez o controle estatal $^{107}$. Assim, sob a mediação da norma, o Estado realiza este controle, impõe sua presença em todos os lugares (direta ou indiretamente), desenvolvendo estratégias que orientam e asseguram a reprodução das relações no espaço inteiro, produzindo-o enquanto instrumento político intencionalmente organizado e manipulado ${ }^{108}$

\footnotetext{
${ }^{105}$ Aqui duas dimensões que se realizam em conjunto, em concomitância, mas que, à título de exposição, são apresentadas de maneira separada.

${ }^{106}$ No $\S 2^{\circ}$ do artigo 143 da Lei Orgânica do Município de São Paulo, relativo à administração e às atividades de planejamento, é explicita a posição de que "os planos integrantes do processo de planejamento deverão ser compatíveis entre si e seguir as políticas gerais e setoriais segundo as quais o Município organiza sua ação".

${ }^{107}$ Mascaro, 2013, p. 121.

${ }^{108}$ Carlos, 2011, p. 76-77.
} 
Ao mobilizar este instrumental para fins de direcionar o processo de urbanização, o Estado direciona também as intervenções no espaço e, por conseguinte, as tendências em que o processo de valorização (ou revalorização, como é o caso do Centro de São Paulo e seu entorno) irá ocorrer. As políticas urbano-territoriais, a partir do momento em que estão postas, imprime ao espaço seu processo de valorização, ao mesmo tempo em que revela a relação direta do Estado (neste movimento de produção do espaço) com os setores econômicos ligados à indústria do imobiliário. Ao promover a relação entre Estado, Capital e espaço, as políticas urbano-territoriais sinalizam as articulações burguesas voltadas à construção material e objetiva do espaço em detrimento da fração de classe proletária que se encontra habitando os lugares visados pela especulação imobiliária. A especulação, enquanto uma razão instrumental ligada às formas e meios para acumulação, torna-se uma prática que fundamenta a ação prática e interventiva do Estado, capaz de orientar as delimitações estratégias no espaço, e, ao mesmo tempo, passam a ser estas também são orientadas por estas políticas. Dessa forma, ao permitir e ao mesmo tempo dar subsídios para as estratégias do capital, no sentido da reprodução do espaço, as políticas urbano-territoriais se constituem enquanto mecanismo instrumental (operativo e normativo) do Estado que contribui significativamente com a extensão da forma-mercadoria ao espaço, metamorfoseando-o, assim, em capital fixo, que permite o incremento do capital circulante como também do trabalho vivo, para fins da reprodução do Centro à luz de seu processo de revalorização.

\subsubsection{As políticas urbano-territoriais e a mundialização do espaço (e/ou urbanização neoliberal)}

Os meados da década de 1980 e o início da década de 1990 caracterizam um período de transição cujo marco, que está de fato na década de 1990, tem como referência o processo de concretização das políticas urbano-territoriais em São Paulo, conforme a consolidação destas sob a lógica neoliberal. As políticas urbano-territoriais nesse período já apresentavam as características que, ao longo da década de 1990, irão caracterizá-las como estratégias em que a produção do espaço urbano passou a ser realizada sob os predominantes neoliberais. Assim, além de lançarem o processo de urbanização nas mãos da iniciativa privada, lançam, por conseguinte, a reprodução da metrópole para novos patamares de realização da formamercadoria, agora, através da cidade enquanto uma produção histórica que permite a realização da acumulação. Dessa forma, o neoliberalismo ${ }^{109}$ compreendido por meio das

\footnotetext{
109 Para Harvey (2012b), o neoliberalismo é, primeiramente, uma teoria das práticas político-econômicas que propõe que o bem-estar humano pode ser mais bem promovido liberando-se as liberdades e capacidades
} 
políticas urbano-territoriais (estas, por sua vez, caracterizadas na forma-mercadoria, mediadora da relação entre o Estado e a iniciativa privada) remete-nos às novas estratégias que passam a ser postas pelas parcerias público-privadas no âmbito da reprodução capitalista da metrópole.

Algumas discussões e exposições textuais são realizadas no sentido de atrelarem o neoliberalismo ao urbanismo ${ }^{110}$, entretanto, no objetivo de compreender o movimento das políticas urbano-territoriais no Centro de São Paulo - o que exigiu o esforço de compreender outras políticas similares em outros lugares da cidade $^{111}$, como também políticas e intervenções anteriores $^{112}$ - consideramos que o neoliberalismo é específico das políticas. Considerar o neoliberalismo enquanto uma particularidade histórica que se realiza através das políticas de Estado, faz com que seu sentido atribuído à prática urbanística (técnica e instrumental, decorrente de uma racionalidade específica) afirme esta prática em função do Estado que, no regime de acumulação capitalista, deriva, também, de uma racionalidade técnica ancorada na normatização e no Estado de direito. Conforme houve o surgimento das políticas de intervenção urbana na metrópole, houve também aquilo que podemos considerar como os ajustes próprios a estas políticas; ou seja, as mesmas, ao longo do tempo, vão sendo aperfeiçoadas enquanto estratégias que "liberam" (literalmente) parcelas significativas de fragmentos da metrópole para o mercado imobiliário. Com ressalvas convém destacar que, no atual estágio do capitalismo, o neoliberalismo é uma característica específica que imprime na reprodução do espaço urbano seus traços particulares ${ }^{113}$. Dando sequência à lógica que deriva do (e afirma o) modo de produção e permite a continuação do regime de acumulação - na produção ininterrupta do valor e das mercadorias - permitindo a reprodução das suas relações específicas.

\footnotetext{
empreendedoras individuais no âmbito de uma estrutura institucional caracterizada por sólidos direitos a propriedade privada, livres mercados e livre comércio. O papel do Estado é criar e preservar uma estrutura institucional apropriada a essas práticas [...]. [O Estado] deve também estabelecer as estruturas e funções militares, de defesa, de polícia e legais requeridas para garantir o direito de propriedade individuais e para assegurar, se necessário pela força, o funcionamento apropriado dos mercados; caso não existam mercados, estes devem ser criados e, se necessário, pela ação do Estado (p.12). Já para Duménil e Levy (2014), o neoliberalismo é entendido como um novo estágio do capitalismo que surgiu na esteira da crise estrutural da década de 1970 e que expressa a estratégia das classes capitalistas aliadas aos administradores do alto escalão, especificamente no setor financeiro, no intuito de reforçar sua hegemonia e expandi-la globalmente.

${ }^{110}$ Smith (2005), Sanfelici (2007) e Brenner, Theodore e Peck (2009).

${ }^{111}$ OUFL, OUAE, OUAB e, em preparação, Arco do Futuro (este composto pelo Arco do Tietê, Arco do Tamanduateí que atravessam os limites da área central).

${ }^{112}$ OUVA, OU Interligadas.

${ }^{113} \mathrm{Na}$ privatização do urbanismo os conteúdos que permitem compreender a cidade como aquilo que foi historicamente produzido e que, atualmente, é entregue à iniciativa privada para que, por meio desta forma e por meio da reprodução de seu espaço, continue a realizar o processo de acumulação.
} 


\subsubsection{A reversão das conquistas de classe na cidade}

Até a década de 1980 o processo de urbanização da metrópole, enquanto processo que se realizou através de condições e conflito de classes, permitiu à classe trabalhadora algumas formas peculiares de acesso à cidade. A periferia, em processo de explosão-implosão, passa a ser o espaço socialmente produzido que oferece à classe trabalhadora as possibilidades de moradia em condições de precariedade. O processo de urbanização das glebas até então rurais e marcados pelo processo de fracionamento e/ou pulverização de parcelas do espaço, não ofereciam condições infraestruturais suficientes para comportar todo contingente populacional. Assim, a periferia explode e, ao mesmo tempo, afirma seus conteúdos em que a paisagem marcada pelo processo de autoconstrução e pouca (ou quase nenhuma e até mesmo nenhuma) infraestrutura determinam aquele momento em que a luta da classe trabalhadora por condições de manutenção da reprodução da força de trabalho ${ }^{114}$ era também a luta pela moradia (ou condições de moradia) na periferia de São Paulo. Por mais que o processo de urbanização ocorresse através de condicionantes de precariedade e, ao mesmo tempo, que a reprodução da classe trabalhadora levasse a periferia de São Paulo a ocupar índices significativos de violência e taxa de mortalidade, o acesso à cidade (enquanto forma de moradia) ainda era possível, como também influenciado, por meio dos financiamentos dos materiais, ou mesmo através da regularização dos loteamentos até então irregulares, bem como pelo incentivo à autoconstrução através de mutirões. Ao mesmo tempo em que a cidade explodia na sua extensão, a periferia implodia em conteúdos que, balizados por elementos de classe e caracterizações das lutas daquele momento, permitiam também aos sujeitos se reconhecerem a partir daquela prática. De certa forma, o processo de urbanização da cidade de São Paulo produziu a metrópole em conteúdos de classe específicos em que a autoconstrução se realizou enquanto prática classista que, por sua vez, também produziu a metrópole enquanto prática negativa da cidade enquanto valor de troca.

Compreender o processo de urbanização através de uma leitura de classes exige o exercício de analisar historicamente, e, ao mesmo tempo, expor o processo naquilo que o afirma e o nega. No caso da classe trabalhadora e a produção do espaço na periferia da cidade de São Paulo, a prática (de luta e de resistência) apenas se torna negativa quando considerada

\footnotetext{
${ }^{114}$ Para aprofundar nos detalhes deste momento do processo de produção do espaço da metrópole ver Vários autores (1982), Bolaffi (1982), Bonduki e Rolnik (1982), Damiani (1993), Kowarick (1979), Maricato (1982, 1995, 2013, 2014), Singer (1979), Taschner (1979).
} 
em relação ao acesso à cidade ${ }^{115}$ que se realiza somente no valor de troca. Quando esta mesma prática de autoconstrução é realizada enquanto aquilo que nega o valor de troca e, ao mesmo tempo, apresenta a cidade enquanto aquilo que se realiza em função do valor de uso, a situação se reverte e o que passa a ser posto no horizonte é uma realidade mais rica e maior, portanto aquela do direito à cidade.

Conforme houve esse movimento de explosão da periferia, do adensamento e concentração de seus conteúdos (todos marcados por conflitos e determinantes de classe), a vida cotidiana e a realidade da metrópole - ainda marcada pelo contexto da indústria de transformação - permitiam vislumbrar novas possibilidades em torno dessa configuração que se realizava. Não há um ano ou um fato específico que marque uma mudança abrupta no processo de produção do espaço urbano da cidade de São Paulo. Para uma possível "afirmação da cidade enquanto valor de troca", o que podemos considerar - e nesse caso, com todas as ressalvas possíveis - é que foi em meados da década de 1980 que as condições para a realização do processo de mundialização do espaço (e/ou urbanização neoliberal) foram permitidas.

Nesta década houve, praticamente, um retrocesso nas conquistas históricas da classe trabalhadora e sua relação com a metrópole, pois, o apoio à autoconstrução por meio do financiamento do material de construção é cancelado, a COHAB-SP e a Emurb não promoveram mais parcerias com associações de moradores de bairro. Apesar da "urbanização" de favelas, dos mutirões, da regularização fundiária, das obras de saneamento também de favelas terem ido até o final do mandato da prefeita Erundina (1989 - 1992), em Dezembro de 1986, a administração Jânio Quadros influenciada pelo Banco Mundial, iniciava as atividades das Operações Interligadas como uma política de remoção de favelas ${ }^{116}$. Não houve uma mudança repentina ou um fato que marcou uma possível transição. Houve, a nosso ver, uma transição gradual de um processo de mundialização que já apontava tendências de sua realização através da cidade e do urbano. Em São Paulo, essa transição ocorreu através de uma sucessão de fatos que, marcados pela realidade conflitiva das classes na produção e no uso do espaço urbano, foram também apresentando soluções de classe para aquilo que estava surgindo.

Em relação ao Centro de São Paulo, o Estado assegurava as condições ao permitir os mecanismos para o desdobramento da centralidade sentido sudoeste, ao mesmo tempo em que

\footnotetext{
115 Enquanto possibilidade de morar (habitar) nos lugares da cidade que oferecem maiores condições de mobilidade, lazer, estudos, trabalho etc.

${ }^{116}$ Van Wilderode, 1994.
} 
também criava possibilidades de reprodução do capital a partir da reprodução da metrópole. A vida cotidiana apontava as temporalidades e as novas relações de uma metrópole que, cada vez mais, se desvencilhava das condições de produção industrial e se afirmava enquanto metrópole do setor financeiro de dos serviços avançados. A transição do industrial para o financeiro apontava os elementos que encadeavam o processo de sua própria reprodução, enquanto forma de produção do valor, realização do valor de troca e efetivação da formamercadoria em sua própria estrutura.

A metrópole produzida historicamente acumulou uma série de condições que, aos poucos, metamorfoseou-a em força produtiva. Através destas condições acumuladas historicamente, surgia o "germe" para as políticas urbano-territoriais, conforme a maneira de como elas ocorrem na atualidade; estas novas políticas, por sua vez, contribuíram significativamente para a reversão das conquistas históricas que o proletariado havia conseguido, ainda mais em relação às práticas de autoconstrução na extensa periferia de São Paulo. No Centro, principalmente quando levamos em conta a tendência que foi posta por estas políticas, o que há é um violento processo de revalorização que tende, cada vez mais, a eliminar do Centro de São Paulo o proletariado que ainda o ocupa. E isso ainda mais quando avaliamos suas "extremidades" e seu entorno imediato, portanto, os lugares em que estão densamente ocupados por parcelas mais pobres da população.

A delimitação de territórios para a intervenção no Centro de São Paulo é o momento em que a estratégia é posta em prática para fins de gerir a produção de um espaço que se pretende homogêneo. Também é o momento específico em que o espaço se reproduz à luz da sua própria mundialização, ou seja, não apenas as instituições financeiras e os fluxos de capital passaram a determinar o atual processo neoliberal de regulação e redefinições em escala mundial, o espaço também compõe este movimento. Isso significa que há um duplo movimento quando devemos considerar aquilo que os autores chamam de "urbanização neoliberal", ou seja, para além dos processos de destruição criativa ${ }^{117}$ que apontam o urbanismo neoliberal como uma espécie de estratégia econômica que busca contornar a crise, a compreensão das intervenções como um processo e mecanismo específico do momento da

\footnotetext{
${ }^{117}$ Segundo Brenner, Peck e Theodore (2009, p.57), o processo de "destruição criativa" foi se desdobrando em uma variedade de escalas geográficas e na variedade de instituições locais no começo da década de 1970. Os autores argumentam que as cidades se converteram estrategicamente em importantes arenas no qual formas neoliberais de "destruição criativa" foram se desenvolvendo. A localização central das cidades nos sistemas fordistas-keynesianos de produção e reprodução as define como arena-chave (se não os próprios alvos para as estratégias neoliberais de reversão da condição anterior. Assim como crucialmente, a estratégia significante das cidades como o loci (lugar em latim) da inovação e do crescimento, e como zonas de governança descentralizada e experimentação institucional local, da mesma forma que os posiciona na vanguarda institucional e geográfica dos programas neoliberais em curso.
} 
mundialização do espaço prolonga esta noção estritamente econômica. Ao prolongar esta noção econômica a mundialização do espaço lança a problemática para uma amplitude maior, cuja compreensão e exposição tem como pressuposto maior a vida cotidiana, além claro, das relações entre o público e o privado, e o processo de mundialização que se realiza a partir do lugar. Portanto, a delimitação dos territórios - enquanto um procedimento técnico das intervenções estatistas no espaço socialmente produzido de São Paulo - representa um mecanismo específico que se realiza sob o domínio específico do Estado, cujas consequências (que já estão determinadas e postas enquanto condição da reprodução) são a homogeneização, a hierarquização e a fragmentação da cidade, como também do urbano.

Se na década de 1980 - e mais especificamente em 1986 - o governo Jânio Quadros, sob pressão do Banco Mundial, já apresentava aquilo que posteriormente seria predominante, é na década de 1990 que as Operações Urbanas em São Paulo se afirmam (e são afirmadas) enquanto políticas neoliberais que privatizam os fragmentos do espaço urbano. Essa privatização do espaço ocorre através territórios estrategicamente delimitados que passam a determinar os fragmentos da metrópole em função da realização do valor de troca e, consequentemente, da forma-mercadoria. Ou seja, o capitalismo, enquanto um regime de acumulação que se realiza na produção contínua do valor (mais especificamente o maisvalor), sempre busca novas formas de realização da acumulação. Contudo, os mecanismos específicos que realizam esta acumulação ocorrem apenas no desenvolvimento contraditório da luta de classes, logo, um cenário perfeito para as práticas neoliberais que são operadas por meio da exclusão.

A operação urbana e as obras de intervenção no Centro de São Paulo - assim como também as demais Operações Urbanas que ocorrem em outros lugares da metrópole carregam em si essa marca do neoliberalismo, ou seja, enquanto intervenções que são postas em prática somente por via da exclusão e expropriação, por meio destas, foram criados mecanismos específicos que dificulta o acesso à propriedade privada do solo urbano nos lugares em que estas se realizam ${ }^{118}$. Para Brenner, Peck e Theodore $(2009$, p.8) a "meta última de tais experimentos neoliberais de políticas urbanas é mobilizar espaços da cidade tanto para o crescimento econômico orientado ao mercado, como para as práticas de consumo das elites, assegurando ao mesmo tempo a ordem e o controle das populações excluídas". Segundo os autores, estas políticas urbanas se realizam através de um tratamento de shock de

\footnotetext{
${ }^{118}$ Segundo Carlos (2004), quando o potencial do adicional construtivo é posto no mercado para compra e venda, o preço do metro quadrado é aumentado significativamente. Consequentemente, nos lugares em que foram delimitados territórios de operações urbanas, tendencialmente o preço do metro quadrado também tende a aumentar.
} 
desregulação, privatização, liberalização e maior austeridade fiscal ${ }^{119}$ que desencadeiam em vários discursos como o marketing territorial, a criação de zonas empresariais, a redução de impostos locais, o impulso as relações público-privadas e novas formas de promoção social ${ }^{120}$.

Outro fator preponderante, talvez o mais significativo, é que, nos territórios onde são realizadas as operações urbanas em São Paulo, praticamente tudo é posto em suspensão sob a violência e a coerção do Estado, inclusive a propriedade privada do solo urbano ${ }^{121}$. No caso do Centro de São Paulo as intervenções urbanas (tanto na operação urbana quanto na concessão urbanística) revelam a ideologia da instrumentalidade técnica a favor da produção do espaço. A delimitação de territórios de intervenção onde há o predomínio do poder do Estado, inclusive para por em suspensão a propriedade privada do solo urbano através da "ferramenta" de outorga onerosa, consiste apenas nos primeiros momentos da proposta urbanística enquanto ideologia. Quando nestes territórios há o que podemos considerar como "processo de privatização do espaço", há, em primeira vista, uma realidade redutora que sequer apresenta os conflitos e as tensões de classe que derivam desta mesma realidade. Sob o valor de troca o capitalismo homogeneiza a cidade e o urbano, as pessoas e a produção, a troca e o consumo; contudo, ao realizar este tipo de homogeneização, somente a faz através de fragmentos e fragmentações, inclusive a do sujeito. O território delimitado pode até por em suspensão a propriedade privada do solo urbano através de mecanismos - portadores de uma violência legitimada e legitimadora - que são específicos a esta prática. Contudo, os limites para a realização destas políticas de intervenção estão postos tanto na tensão de classe que deriva destas mesmas condições, quanto na própria vida cotidiana em que se sucedem estes acontecimentos na cidade e no urbano.

\subsubsection{Operação Urbana Centro}

A Operação Urbana Centro, no âmbito das operações urbanas na cidade de São Paulo, contém em sua especificidade os limites que também são impostos pelo fenômeno da raridade

\footnotetext{
119 Para os autores, o contexto de neoliberalização tem convertido as cidades (e suas zonas suburbanas de influência) em bancos geográficos cada vez mais importantes, e também laboratórios institucionais para diversos experimentos de políticas neoliberais, como o marketing territorial, a criação de zonas empresariais, a redução de impostos locais, o impulso às relações público-privadas e novas formas de promoção local. Para isso, recorrem a sistemas de prestações sociais condicionados, planos de desenvolvimento das propriedades, novas estratégias de controle social, ações policiais e de vigilância, e uma bateria de outras modificações institucionais ao interior do aparato estatal local (BRENNER, PECK, THEODORE, 2009, p.8).

${ }^{120}$ Ibidem.

${ }^{121}$ Isso não significa que ela perde seu significado enquanto propriedade privada, pelo contrário. Ocorre que nestas condições a propriedade privada do solo urbano (edificada ou não edificada) fica a cargo do Estado que, ao produzir também os lugares da metrópole (nesse caso o espaço público), realiza o processo de metamorfose destes, sob os álibis específicos. Neste momento, a propriedade privada entra numa espécie de regime de exceção (para que seja expropriada) de maneira que, no momento seguinte, possa ser "devolvida" ao mercado sob o predomínio do valor de troca, com todos elementos e identidades posteriores do espaço já produzido enquanto mercadoria e, assim, realizar o ciclo da acumulação.
} 
do espaço. Este fato não significa exatamente que o Centro, adensado e concentrado pelos diversos tipos de excessos do processo de urbanização, seja um fragmento da metrópole que não interesse ao processo capitalista de reprodução; talvez ocorra o contrário, conforme a realidade nos conduz na observação e encadeamento dos fatos. Alguns pontos devem ser destacados para que se compreenda a particularidade da Operação Urbana Centro: 1) a O. U. Centro não é uma operação urbana consorciada; 2) sua proposta gira em torno da oferta de benefícios para atração de empreendimentos privados para o Centro de São Paulo; 3) ela desloca a compreensão do que é o Centro de São Paulo compreendido nos distritos Sé e República para os distritos no entorno, chamado de área central; 4) oferece à iniciativa privada todas as condições urbanísticas para modificar a paisagem do Centro de São Paulo; 5) ela centraliza, atualmente, os conteúdos que estão postos para a transformação do Centro de São Paulo através do PDE, PRE, LPUOS e articulação com outras políticas urbanoterritoriais.

Vários fatores e dinâmicas da realidade, inerente às intervenções no Centro de São Paulo, apontam para a relação das intervenções com os interesses de reprodução do capital a partir da reprodução do Centro, inclusive àqueles ligados a articulação de políticas específicas para este fragmento da metrópole. A Operação Urbana Centro amarrou em si outras duas políticas que foram estratégias do ponto de vista do Estado para o Centro de São Paulo - por mais que uma delas não veio a se realizar, ficaram claros os interesses do poder público no Centro de São Paulo - e, atualmente, centraliza um fragmento (setor) específico que determina o devir de redefinições no espaço da metrópole ${ }^{122}$.

A raridade do espaço no Centro de São Paulo revela pela própria Operação Urbana Centro os limites impostos pela contradição que atravessa este fragmento da metrópole. Diferente de outros lugares onde as operações urbanas mobilizam uma quantidade significativa de dinheiro em arrecadações, no Centro trava-se uma disputa por este espaço que, nos últimos 30 anos, praticamente, vêm sendo ocupado cada vez mais pelas parcelas mais pobres da população ${ }^{123}$. Ainda considerando as operações urbanas em outros lugares da

\footnotetext{
${ }^{122}$ Conforme a Lei ${ }^{\circ} 16.050$ de 31 de Julho de 2014, que dispõe sobre a Política de Desenvolvimento Urbano, o Sistema de Planejamento Urbano e o Plano Diretor Estratégico do Município de São Paulo.

${ }^{123}$ Foi o que consideramos anteriormente como o processo de proletarização do Centro de São Paulo.
} 
metrópole ${ }^{124}$, no Centro de São Paulo a Operação Urbana é portadora de uma característica que é central em nossa análise pelo fato de não ser uma operação urbana consorciada ${ }^{125}$.

Figura 5 - Operação Urbana Centro e distritos do entorno

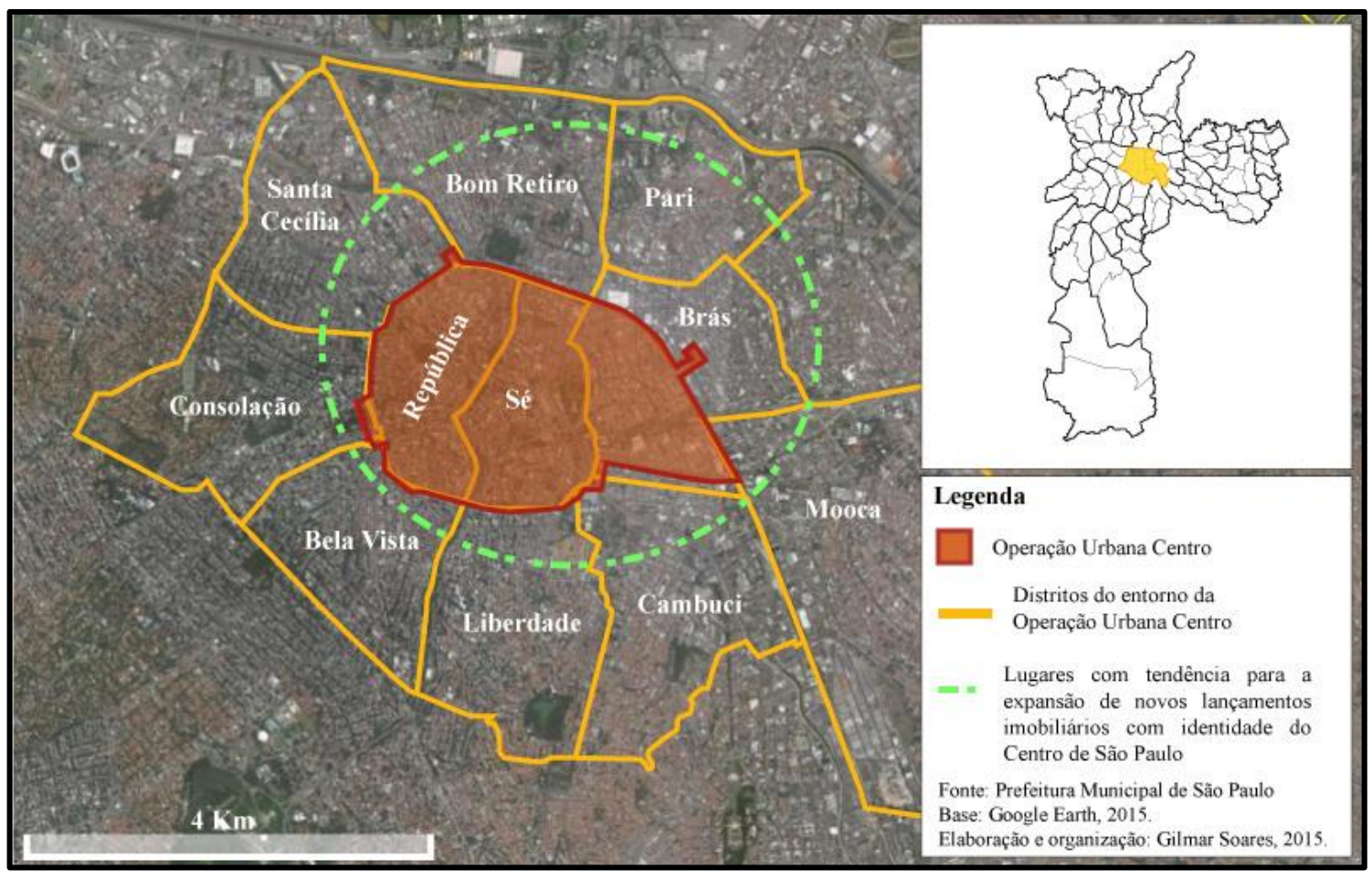

A Operação Urbana Centro resulta da Lei nº 12.349, de 6 de Junho de 1997 e contém um "conjunto integrado de incentivos à produção imobiliária que combinados à atuação do Poder Público e da sociedade civil - empreendedores, usuários e moradores, visam promover a reordenação urbanística da área central" (SP-URBANISMO, 2010). Evidente que a estratégia do Estado, publicada em forma de lei, explicita de maneira clara os interesses da política quando aponta os incentivos à produção imobiliária e o objetivo de promover a reordenação urbanística da área central. A importância em destacar estes dois fatos está naquilo que a própria lei aponta e se constitui enquanto tendência para reverter os entraves postos pela raridade do espaço no Centro de São Paulo. Ao definir como reordenação urbanística da área central, tanto a Prefeitura Municipal de São Paulo quanto as entidades de classe (nesse caso, enfatizamos a Associação Viva Centro) projetam para além dos distritos

\footnotetext{
${ }^{124}$ Como é o caso da Operação Urbana Água Branca, Operação Urbana Faria Lima e Operação Urbana Água Espraiada.

${ }^{125}$ Operação urbana consorciada é o conjunto de intervenções e medidas coordenadas pelo poder público municipal, com a participação dos proprietários, moradores, usuários permanentes e investidores privados, com o objetivo de alcançar em uma área transformações urbanísticas estruturais, melhorias sociais e valorização ambiental (ESTATUDO DA CIDADE, 2001).
} 
Sé e República as estratégias para retomar a reprodução capitalista deste fragmento da metrópole.

Além disso, a Operação Urbana Centro se diferenciará das demais operações urbanas e políticas de intervenção no Centro de São Paulo pelo fato desta centralizar em si as demais intervenções que estão postas para o Centro. Vale salientar também que, por se tratar de um processo de produção do espaço, ao delimitar estes territórios de intervenção o Estado produz uma espécie de suporte que regula e ordena sob finalidades especificas e se realizam em sinergia com o espaço econômico dos agentes da indústria imobiliária. Ao regular e ordenar, no sentido de uma reordenação do espaço, o espaço enquanto objeto direto das ações do Estado torna-se produto político - nesse caso, de uma política de classe que coaduna com as medidas do Estado Burguês - ao mesmo tempo em que o mesmo conteúdo político o produz sob um determinado sentido, que é o de sua reprodução capitalista. É neste sentido que as relações de reprodução do Centro vão se redefinindo ao longo do tempo sob o mote ideológico do urbanismo de revitalização e/ou requalificação do Centro.

Ao lançar o Centro de São Paulo para o conjunto de práticas que o conduzem à sua mundialização, o que se tem como horizonte (do ponto de vista do capital) revelador do processo de homogeneização, são as práticas ligadas à produção e consumo do espaço que, por sua vez, coadunam e revelam as potencialidades do Centro na totalidade de reprodução capitalista da metrópole. Ferreira (2003) considera este mesmo processo como uma estratégia que vai ao sentido de construir uma representação ideológica ${ }^{126}$ de cidade global, e, Anunciação (2005) o analisa no sentido de transformação da paisagem e dos lugares no Centro, incorporando na área central ações que fazem parte de demandas globais. Evidente que o Centro de São Paulo entra também nesta seara de metrópoles e cidades mundiais que tiveram um processo de transformação em seu Centro. Smith (2006) concebe este fenômeno de desvalorização dos Centros em escala global a partir da noção de gentrificação, elencando também o caso da cidade de São Paulo como um caso recente, enquanto uma "expressão urbana acabada de um neoliberalismo" (p. 80). Assim como Ferreira e Smith, Arantes (2012a, p. 19) compreende estes processos ${ }^{127}$ através da noção de gentrificação ligada a maquina urbana de crescimento.

\footnotetext{
${ }^{126}$ Em contraposição à realidade concreta em que o desdobramento da centralidade sentido vetor sudoeste, na verdade, revelam também os interesses de conduzir para este setor da cidade os empreendimentos imobiliários que maior custo e que tendem a valorizar ainda mais o espaço e os imóveis nestes lugares.

${ }_{127}$ Arantes (2012a, p. 19) destaca sobre o eufemismo de várias palavras para aquilo que ela considera como o processo de gentrificação: revitalização, reabilitação, revalorização, reciclagem, promoção, requalificação, renascença etc.
} 
O processo de revalorização dos Centros das metrópoles e/ou cidades é, por excelência, uma prática capitalista de produção do espaço que visa especificamente à reprodução do capital, ao mesmo tempo em que permite o retorno das burguesias ao lugar de onde elas saíram ao longo do tempo. Conforme foi observado, a revalorização não é um processo imediato, afinal, (HARVEY, 2014, p. 51) salienta que "a burguesia levou mais de cem anos para concluir a conquista do centro de Paris". O tempo da disputa pelo espaço é exatamente o tempo que faz com que essas disputas se prolonguem, sem por em xeque as estruturas que asseguram a reprodutibilidade da sociedade de classes e, por conseguinte, da burguesia. Neste sentido, várias estratégias em nível de Estado vão sendo realizadas e postas em prática em sinergia com o capital. Este é o mesmo sentido que faz com que a reprodução do espaço, inerente aos processos de revalorização dos Centros das metrópoles e das cidades, também sejam reconhecidos através da mundialidade difundida a partir de modelos que tiveram êxito, como foi o caso de Barcelona.

Nestes termos, a homogeneidade do processo de desvalorização e as estratégias de como lidar com o processo devem reconduzir o pensamento para o momento atual em que a reprodução do espaço é uma das saídas para o capital acumulado. Entretanto, como o processo de reprodução não é homogêneo e também caracterizado pelas contradições de classe, tanto as políticas de intervenção quanto o próprio processo de revalorização tendem a se realizar em dinâmicas específicas, conforme cada cidade e cada lugar. As políticas e as estratégias variam tanto no tempo como no espaço, como é o caso da Cultura enquanto álibi ${ }^{128}$ para a revalorização. Em todos os casos o Estado torna-se central, afinal, em relação com a cidade e o urbano, o Estado redefine os conteúdos do espaço à luz da reprodução do capital e das possibilidades de acumulação. Esta aproximação é feita somente através das políticas que, em seus detalhes, revelam as dinâmicas do processo.

Enquanto política espacial, a Operação Urbana Centro é o instrumento urbanístico que oferece incentivos à produção imobiliária e reordena urbanisticamente a área central em sintonia com as estratégias de classe, aquelas que visam à reprodução do capital por meio da produção imobiliária e do deslocamento do proletariado dos espaços que tendem a receber a pequeno-burguesia. Quando esta operação urbana oferece os benefícios de concessão de exceções a LPUOS (Lei de parcelamento, uso e ocupação do solo) e ao COE (Código de obras edificações), através de remembramento de lotes, conservação do imóvel de interesse histórico e reconstrução ou reforma de edifícios, o que são concedidos são apenas os

${ }^{128}$ As considerações sobre a cultura serão aprofundadas no item 2.2. desta dissertação. 
benefícios para os proprietários de edifícios que concebem o Centro de São Paulo a partir da possibilidade de obtenção de rendimentos através destes imóveis. A concepção do imóvel urbano $^{129}$ (ainda mais no Centro de São Paulo) como um ativo que permite ou permitirá a obtenção de rendimentos futuros, talvez auxilie na compreensão do que vem a ser o fenômeno da vacância imobiliária na atualidade. No perímetro da Operação Urbana Centro os benefícios são oferecidos para edifícios residenciais (subcategoria R2v), cujo coeficiente de aproveitamento máximo do terreno é igual a 6,0, para edifícios de uso misto (uso residencial $\mathrm{R} 2 \mathrm{v}$ e de estacionamento $\mathrm{nR} 2$ ), com os mesmos coeficientes de aproveitamento e a taxa de ocupação mantida nos limites da zona de uso.

A Operação Urbana Centro não contempla, pelo menos neste seu momento atual, o incentivo por completo à realização da construção de novos empreendimentos, a não ser pequenos empreendimentos em alguns pequenos lotes que ainda estão disponíveis. Conforme veremos mais adiante, para os lançamentos imobiliários para uso residencial (R2.O2) não há exigência de reserva de espaço para estacionamento de veículos e, no caso de houver a hipótese de haver, a área não será computada no limite máximo de certificado de aproveitamento. Pelo menos no que tange a produção imobiliária, em relação ao perfil dos lançamentos que estão dados nos distritos Sé e República, dispensa-se a reserva de espaço para estacionamentos e fica apontada a tendência ao incentivo da produção imobiliária de menor porte nas unidades habitacionais, como os studios por exemplo. Evidente que as condições de escassez de espaço contribuem com esta tendência, contudo, o elevado grau de coeficiente de aproveitamento exige o máximo de densidade construtiva no lote ${ }^{130}$. Pelo menos até este momento, a impressão que temos é que o cuidado com as intervenções no Centro de São Paulo decorrem especificamente das condições que lhes são próprias, pois, além de ser um fragmento da metrópole superedificado, atravessado pela escassez de espaço, este é também o espaço que é caracterizado pelas formas de apropriação via ocupação. Historicamente, conforme estamos expondo ao longo desta dissertação, o fato, em relação ao Centro de São Paulo (e seu entorno composto por distritos limítrofes), é que praticamente em todos os seus momentos houve a ocupação de parcelas significativas das classes proletárias de São Paulo. Os Cortiços, históricos no Centro de São Paulo e as habitações operárias confirmam a história.

\footnotetext{
${ }^{129}$ Nos termos postos da propriedade privada do solo urbano, ou mesmo da propriedade privada do espaço.

${ }^{130} \mathrm{O}$ que também aponta a uma tedência de densificar no espaço perfis específico, portanto, pessoas de classes sociais semelhantes, bem como demonstram também interesses semelhantes em habitar esta porção da metrópole. Os apartamentos reduzidos, geralmente com apenas 01 quarto e/ou em formato de studios, aponta para esta tendência. Ou seja, pessoas predominantemente jovens, com um certo rendimento mensal, solteiras(os), dispostos a consumir e ter um padrão de vida semelhante.
} 
Ocorre que, atualmente, com o processo de intensificação deste fato (a ocupação proletária do Centro de São Paulo e seu entorno), as intervenções do Estado para reverter esta situação acabam ocorrendo com parcimônia, lentidão, num processo em que as formas de dominação e controle espoliam os sujeitos de todas as formas possíveis, que vão desde o "desmonte" das apropriações dos espaços construídos que estavam vazios (as ocupações), passando pela "caça" (literalmente) dos trabalhadores do comércio informal, e chegando até os "jatos d'água" da Prefeitura debaixo das marquises e viadutos (para "limpar" o espaço público do Centro). De "apenas mais um instrumento de intervenção urbanística para o Centro de São Paulo", a Operação Urbana Centro se tornou numa espécie de "nó" estratégico por qual flutuam e orientam-se outras intervenções espaciais e estratégias de revalorização do espaço, conforme veremos mais adiante.

Enquanto uma política do Estado que se realiza especificamente no espaço, a Operação Urbana Centro, por meio da delimitação estratégica de um território específico, intervém gradualmente, passo a passo, em que, aparentemente, a impressão que se tem é de que a Prefeitura Municipal de São Paulo faz questão do controle integral do processo interventivo. $\mathrm{O}$ cuidado com as condições atuais (principalmente aquelas relacionadas ao grau elevado da ocupação proletária do Centro de São Paulo) parecem revelar-se no movimento lento que a intervenção caracteriza. Ao invés de "destruir", talvez a melhor justificativa (ou álibi) seria reformar, ou seja, tombar a paisagem para manter as estruturas arquitetônicourbanísticas no Centro de São Paulo, exigindo sua reforma e/ou manutenção. Ao espaço superedificado (e à luz do capital) esta seria uma estratégia tida como excelência, afinal, além de justificar todas as expropriações de edifícios vazios ocupados no Centro de São Paulo e seus distritos de entorno, o que se desenvolveria a partir do espaço superedificado e hiperadensado do Centro de São Paulo, seria uma espécie de desencadeamento de práticas de Retrofit Total destes imóveis que posteriormente seriam postos a venda, como bens históricos tombados que compõem a paisagem do Centro da metrópole.

No âmbito da construção civil a própria realidade urbana explodida e implodida exige a renovação (ou reforma completa) das suas estruturas e infraestruturas, principalmente nos lugares mais antigos da metrópole. A ocorrência da renovação das formas urbanas e arquitetônicas, no domínio da cidade enquanto força produtiva e capital fixo, revela o significado do momento da reprodução do espaço e a superação histórica deste tipo de produção no sentido de reverter os "impasses" dos espaços superedificados e desvalorizados. A respeito do retrofit, Moura (2008) apresenta uma ressalva importante quando considera que 
atrelado ao boom imobiliário, o mercado de retrofit vem crescendo nos grandes centros urbanos do País, onde as áreas para novos empreendimentos estão cada vez mais escassas e caras. Disputados pelos investidores do setor imobiliário, esses edifícios antigos, depois de modernizados, oferecem, além de localização privilegiada, retorno do investimento após um período curto de obra. Meus grifos

A escassez de espaço, não só no Centro de São Paulo faz com que o Retrofit Total dos edifícios torne-se um negócio rentável no processo de revalorização dos Centros urbanos. Em São Paulo, o PDE de 2014 aponta, na necessidade de revisão da Lei de Parcelamento, Uso e Ocupação do Solo o estímulo ao Retrofit das edificações para novos usos ${ }^{131}$.

A relação entre o Retrofit, enquanto um processo, e a preservação do patrimônio histórico é estrita e sinérgica, do ponto de vista das estratégias para a revalorização dos espaços. Além do mais, abrem também o leque para um segmento econômico que tende a se consolidar com o avanço e desenvolvimento desta indústria do imobiliário: a renovação dos imóveis tombados. No campo direto da revalorização do espaço portador do fenômeno da raridade, o processo de Retrofit total torna-se um novo campo de possibilidade econômica que, na atualidade, ao ser explicitado pela noção de produção do espaço urbano, apresenta-se como uma nova potência de realização de novos negócios no âmbito da reprodução do Centro de São Paulo.

Enquanto uma frente que aponta a possibilidade de abertura aos novos negócios ainda mais quando consideradas no rol das estratégias que visam reverter o desgaste "natural" dos edifícios - a reforma dos imóveis, assegurada pela Operação Urbana Centro, amplia as possibilidades de revalorizar o espaço através de um novo negócio imobiliário que, além de se ancorar na dimensão política, tem como atrativo também os equipamentos de cultura, o tamanho dos imóveis e a localização caracterizada pela quantidade de infraestrutura urbana. Conforme a "retrofitagem" de imóveis aconteçe, os processos de desmonte de ocupações tendem a ocorrer "a galope". Atualmente as condições postas, assim como os planos (diretor, regional, estratégicos etc.), encaminham para esta condição. A primeira (e talvez mais significativa) ocorrência deste fato de desmobilização de uma forma de resistência ocorreu na antiga ocupação Ipiranga, coordenada pela Frente de Luta pela Moradia (FLM).

\footnotetext{
${ }^{131}$ Conforme a $18^{\mathrm{a}}$ diretriz do artigo 27 da Lei 16.050 de 31 de Julho de 2014, que aponta as diretrizes para a revisão da Lei de Parcelamento, Uso e Ocupação do Solo na cidade de São Paulo.
} 
Figura 6 - Ocupação Ipiranga e Edifício Retrofit Vanguard Ipiranga

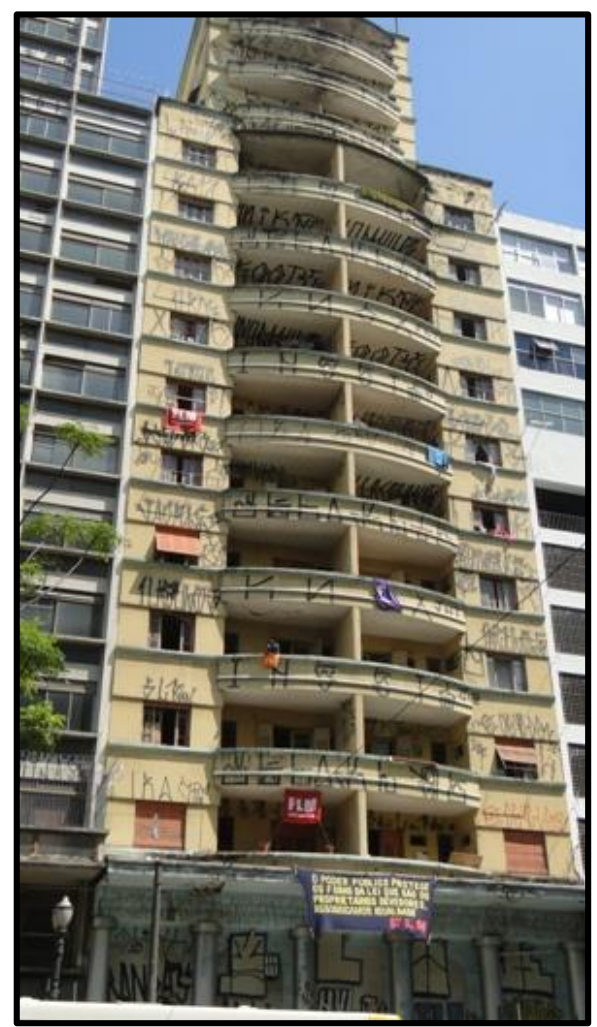

Fonte: site FLM. http://www.portalflm.com.br/wp-

content/uploads/2010/11/IPIRANGADSC02819.jpg

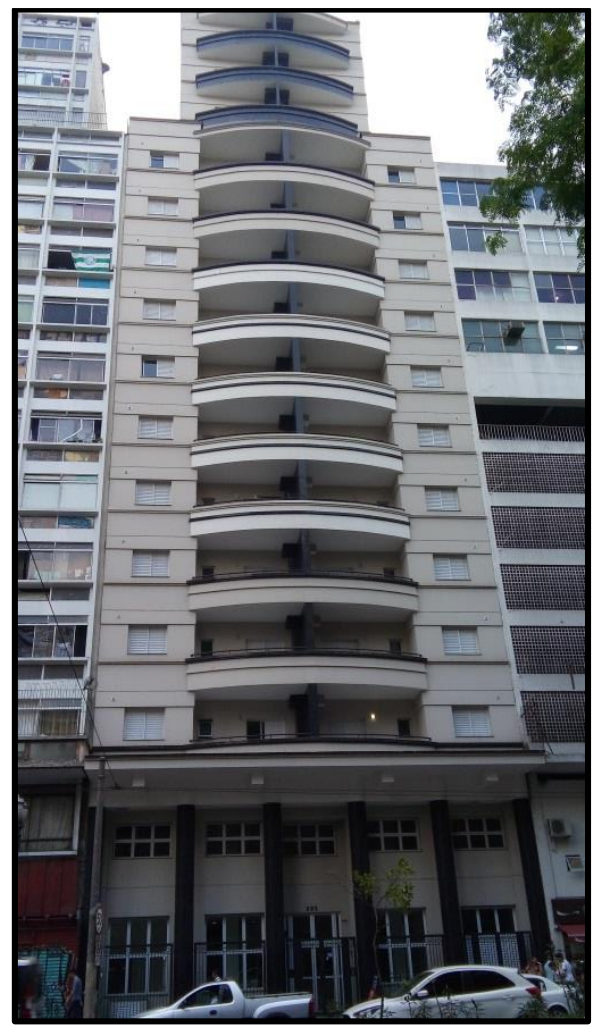

Fonte: Gilmar Soares, 2015

$\mathrm{Na}$ sequência, ao expor aquilo que está posto como incentivos e contrapartidas, o objetivo consiste em apontar como que estes instrumentos urbanísticos contribuem para o movimento de reprodução-revalorização do Centro de São Paulo. Levando em conta que a Operação Urbana Centro não é consorciada, e levando em conta também que estes incentivos são considerados como instrumentos urbanísticos, a impressão que se tem é de que tais instrumentos soam mais como ideologias e discursos urbanísticos vinculados e propalados a partir da Operação Urbana Centro.

Naquilo que está posto na lei como incentivos e contrapartidas, expressivos do artigo $3^{\circ}$ ao artigo $10^{\circ}$, ficam evidentes os mecanismos por qual o Estado controla de domina o espaço socialmente produzido do Centro de São Paulo.

O que veremos na sequência é um conjunto de normativas, inerentes à Operação Urbana Centro, que visam a reforma e a manutenção da paisagem deste fragmento da cidade, principalmente nos distritos Sé e República. Conforme as condições para a reforma total de edifícios que estão quase que por completo deteriorados se desenrolam através da modificação do Código de Obras e Edificações, provavelmente vários destes edifícios são comercializados entre seus proprietários, já que as condições de "deterioração" atribuídas ao 
Centro de São Paulo constituem como um fator positivo à baixa do preço do metro quadrado e, por conseguinte, dos preços de mercado. Além dos edifícios praticamente deteriorados, a paisagem e o lugar também são fatores que compõem esta dimensão bárbara do processo de urbanização que se realiza por meio da reprodução do Centro.

Tornados negócio, tanto a paisagem quando o lugar, ao serem atribuídos por narrativas e predicativos considerados negativos, surtem como álibi ideal aos negociantes e comerciantes de espaço (urbano socialmente produzido) que veem neste fragmento da metrópole - dotado de infraestrutura, equipamentos urbanos e o nó mais significativo do transporte metropolitano - a possibilidade de uma nova fronteira de acumulação.

\section{a) Coeficiente de Aproveitamento}

Praticamente sete artigos compõem o conjunto de normativas inerentes aos incentivos e contrapartida relacionados à Operação Urbana Centro. Alguns com disposições específicas e outros apenas em complementaridade, compõem este conjunto de critérios que determinam as formas de intervenção no Centro de São Paulo. No artigo $3^{\circ}$ desta lei, o coeficiente de aproveitamento é a noção que atravessa todo este conteúdo. No território que circunscreve a esta operação urbana, tem o limite máximo de aproveitamento em 6,0. Castilho (2010, p. 191) ao fazer uma menção sobre o estabelecimento deste coeficiente de aproveitamento no Centro de São Paulo, considera-o extraordinário, talvez seja por que no Centro de São Paulo, além já do elevado grau de concentração das edificações, o grau de ocupação humana do espaço também seja significativamente elevado. $\mathrm{O}$ fato deste benefício ser apenas oferecido aos empreendimentos voltados à construção para uso residencial comprova esta hipótese, pois, ao levarmos em conta o benefício de não ser construído garagem, como também o tamanho dos lotes para a construção, o que nos resta no "horizonte" de averiguação das condições corresponde ao tamanho dessas unidades habitacionais.

Com elevado índice construtivo e com unidades habitacionais de menor tamanho, o que resta ao empreendedor imobiliário são as maiores possibilidades de acumulação com sua mercadoria compacta, nova e vendida sob as novas representações do Centro de São Paulo. Levando em conta à própria noção de Coeficiente de Aproveitamento posta pela Operação Urbana Centro, como a "relação entre o total de área computável edificada e a área do lote" (CARTILHA DA ÁREA CENTRAL, 2010, p. 1), os benefícios aos empreendedores do espaço urbano correspondem, praticamente, às categorias de uso ligadas à construção de 
edifícios para usos residenciais e hotéis de turismo ${ }^{132}$. Levando em conta a quantia movimentada para os investimentos no Centro de São Paulo, fica claro que estas construções residenciais não são voltadas para as populações de baixa renda, ou mesmo que estas se constituam como habitações populares. Dois referenciais norteiam a aplicação do coeficiente de aproveitamento: a outorga onerosa do direito de construir e a transferência de potencial construtivo.

A outorga onerosa, por sua vez, é o instrumento urbanístico que "separa" a propriedade dos terrenos urbanos do direito de edificação (ESTATUTO DA CIDADE: GUIA PARA IMPLENTAÇÃO PELOS MUNICÍPIOS E CIDADÃOS, 2002, P. 72). Assim, a escassez de terrenos no Centro de São Paulo, de certa forma, torna-se um fator que implica alguns limites na aplicação deste instrumento. As construções no Centro de São Paulo se realizam por meio da aquisição de terrenos, ou seja, geralmente o responsável pelo empreendimento imobiliário será aquele que é o proprietário do terreno. O que já não ocorre com a transferência de potencial construtivo, este instrumento, pelo menos até os balanços atuais, já caracterizou $1 / 3$ das solicitações $^{133}$ feitas à SP-URBANISMO, relacionadas à Operação Urbana Centro. Contudo, tanto a transferência (e/ou venda) como a compra de potencial construtivo, somente foram possíveis para imóveis situados fora do perímetro da Operação Urbana Centro ${ }^{134}$. No caso do Centro de São Paulo, principalmente nos distritos Sé e República, a transferência do potencial construtivo ou transferência do direito de construir $^{135}$, somente foi possível porque nestes distritos - assim como no perímetro da Operação Urbana Centro - há uma concentração significativa de imóveis tombados. Não somente um álibi urbanístico, mas também uma estratégia, a cultura se tornou um dos principais fatores para se interferir no espaço urbano, principalmente nos Centros das cidades. Cada vez mais a cultura se torna uma ferramenta útil ao processo de reprodução do espaço e, no caso das intervenções nos centros das cidades onde, geralmente, há o fenômeno da

\footnotetext{
${ }^{132}$ Cujos coeficientes somados (6,0 das instalações hoteleiras, mais 2,0 para os serviços e mais 4,0 para garagem), chegam a 12,0 .

${ }^{133}$ Tabela das solicitações feitas

${ }^{134}$ Referente ao total de 36 solicitações referentes à transferência de potencial construtivo, houveram apenas $13,89 \%$ de aprovação das solicitações que foram feitas. Sobre a compra de potencial construtivo, do total de 37 solicitações feitas até então, houveram $13,51 \%$ de aprovações. Coincidentemente, tanto na transferência (venda) quanto na compra de potencial construtivo o número de solicitações pouco variaram.

${ }^{135}$ Conforme o artigo $35^{\circ}$ do Estatuto da Cidade, a transferência do direito e construir irá se constituir a partir de "lei municipal, baseada no plano diretor, [que] poderá autorizar o proprietário de imóvel urbano, privado ou público, a exercer em outro local, ou alienar, mediante escritura pública, o direito de construir previsto no plano diretor ou em legislação urbanística dele decorrente, quando o referido imóvel for considerado necessário para fins de: I) implantação de equipamentos urbanos e comunitários; II) preservação, quando o imóvel for considerado de interesse histórico, ambiental, paisagístico, social ou cultural; III) server a programas de regularização fundiária, urbanização de áreas ocupadas por população de baixa renda e habitação de interesse social (ESTATUTO DA CIDADE, 2001). Meus grifos.
} 
raridade do espaço, na contrapartida da intervenção, as reformas e a manutenção das reformas nos imóveis tendem a se tornar negócios rentáveis. 
Quadro 1 - Operação Urbana Centro: propostas com venda de potencial construtivo

\begin{tabular}{|c|c|c|c|c|c|}
\hline \multicolumn{6}{|c|}{ Venda de Potencial Construtivo } \\
\hline & PROPONENTE & $\begin{array}{c}\text { LOCAL/ } \\
\text { CONTRIBUINTE }\end{array}$ & S ITUAÇÃO PROCESSO & RESUMO PROPOS TA & CLAS S IFICAÇÃO \\
\hline 1 & $\begin{array}{l}\text { EMPRESA JORNALÍSTICA DIÁRIO } \\
\text { POPULAR LTDA. (Sol Invest) }\end{array}$ & Rua Major Quedinho, 28 - 76 & $\begin{array}{l}\text { APROVADO C/ } \\
\text { TRANSFERENCIA PARA } \\
\text { PROPOST A N } 15\end{array}$ & $\begin{array}{l}\text { Hotel Jaraguá; reforma para instalações hoteleiras. Previsão } \\
\text { de ressarcimento de custos das obras já realizadas para } \\
\text { Restauro e Reciclagem de áreas, anteriormente, ocupadas } \\
\text { por empresa jornalística. }\end{array}$ & Reforma Hotel \\
\hline 2 & $\begin{array}{l}\text { SINTETEL - Sindicato dos Trab. em } \\
\text { Empresas de Telecom. e Op. em } \\
\text { mesas Telef. do Est. de SP }\end{array}$ & Rua Bento Freitas, 76-88 & $\begin{array}{l}\text { APROVADO C/ } \\
\text { TRANSFERENCIA PARA } \\
\text { PROPOST A N } \mathrm{N}^{\circ} 34\end{array}$ & $\begin{array}{l}\text { Restauro, reforma com aumento de área e reciclagem de } \\
\text { edificação residencial para sediar o Sindicato. Obra executada } \\
\text { com recursos da venda de potencial construtivo de imóvel. }\end{array}$ & Restauro Sindicato \\
\hline 3 & $\begin{array}{l}\text { MARCELO ARANHA SOUZA } \\
\text { PINTO E OUT ROS }\end{array}$ & $\begin{array}{l}\text { Avenida São João, } 1214 \text { - } \\
1238 .\end{array}$ & $\begin{array}{l}\text { APROVADO C/ } \\
\text { TRANSFERENCIA PARA } \\
\text { PROPOST A N } N^{\circ} 16\end{array}$ & $\begin{array}{l}\text { Edifício Serviços - uso hoteleiro; restauro e reforma interna } \\
\text { de imóvel tombado com manutenção de uso. Obra } \\
\text { executada, ainda que não na sua totalidade, com recursos da } \\
\text { venda de potencial construtivo de imóvel. }\end{array}$ & Reforma Hotel \\
\hline 4 & $\begin{array}{l}\text { CENTRO CULT URAL BANCO DO } \\
\text { BRASIL }\end{array}$ & $\begin{array}{l}\text { Rua Álvares Penteado, } 112 \text { x } \\
\text { Rua da Quitanda. }\end{array}$ & \begin{tabular}{|l|} 
APROVADO Cl \\
TRANSFERENNCIA PARA \\
PROPOST AS n n $^{\circ} 2$ e $\mathrm{n}^{\circ} 33$ \\
\end{tabular} & $\begin{array}{l}\text { Edifício de Serviços; colaboração de recursos da venda de } \\
\text { potencial construtivo de imóvel no restauro e reciclagem de } \\
\text { edifício tombado p/ implantação de centro cultural. }\end{array}$ & Restauro Centro cultural \\
\hline 5 & FUNDAÇÃO CARLOS CHAGAS & $\begin{array}{l}\text { Rua Conde de Sarzedas x Rua } \\
\text { Dr. Tomas de Lima }\end{array}$ & $\begin{array}{l}\text { APROVADO C/ } \\
\text { TRANSFERENCIA PARA } \\
\text { NOVO EMPREENDIMENTO } \\
\text { LINDEIRO. }\end{array}$ & $\begin{array}{l}\text { Edifício de Serviços; construção nova em terreno com lotes } \\
\text { remembrados; reforma e restauro de edifício tombado } \\
\text { existente no mesmo terreno. Obra de restauro concluída. }\end{array}$ & $\begin{array}{l}\text { Construção Nova e } \\
\text { Reforma e restauro de } \\
\text { edifício tombado }\end{array}$ \\
\hline 6 & $\begin{array}{l}\text { BANCOOP - Cooperativa } \\
\text { Habitacional dos Bancários }\end{array}$ & $\begin{array}{l}\text { Rua Cons. Moreira de Barros, } \\
1212\end{array}$ & \begin{tabular}{|l} 
APROVADO Cl \\
TRANSFERENCIA DA \\
PROPOST A N ${ }^{\circ}$ EMURB 31 \\
\end{tabular} & $\begin{array}{l}\text { Residencial. Obra nova viabilizada através da compra de } \\
\text { PCA de imóvel tombado; }\end{array}$ & Obra nova \\
\hline 7 & $\begin{array}{l}\text { BANCOOP - Cooperativa } \\
\text { Habitacional dos Bancários }\end{array}$ & Rua Afonso Celso, 171 & $\begin{array}{l}\text { APROVADO COM } \\
\text { TRANSFERENCIA DE } \\
\text { POTENCIAL DA PROPOST A } \\
N^{\circ} \text { EMURB } 51\end{array}$ & $\begin{array}{l}\text { Residencial; obra nova a ser viabilizada através da compra de } \\
\text { PCA de imóvel tombado. }\end{array}$ & Obra nova \\
\hline 8 & CONST RUTORA T ARJAB LTDA & $\begin{array}{l}\text { Rua Dias de Toledo, } 384 \text { - } \\
402\end{array}$ & \begin{tabular}{|l} 
APROVADO COM \\
TRANSFERENCIA DA \\
PROPOST A N ${ }^{\circ}$ EMURB 58. \\
\end{tabular} & Residencial; obra nova . & Obra nova \\
\hline 9 & $\begin{array}{l}\text { COMERCIAL E INCOPORADORA } \\
\text { FRESNO S.A. }\end{array}$ & A1. dos Jurupis, 303-335 & $\begin{array}{l}\text { APROVADO Cl } \\
\text { TRANSFERENNCIA DA } \\
\text { PROPOST A N }{ }^{\circ} \text { EMURB } 58 \\
\end{array}$ & Edifício Residencial; obra nova. & Obra nova \\
\hline 10 & $\begin{array}{l}\text { COMERCIAL E INCOPORADORA } \\
\text { FRESNO S.A. }\end{array}$ & Al. Açocê, 562 & 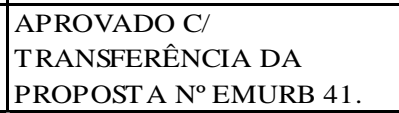 & Edifício Residencial; obra nova. & Obra nova \\
\hline
\end{tabular}

Fonte: Prefeitura Municipal de São Paulo

SP - URBANISMO. Operação Urbana Centro

Quadro de propostas apresentadas.

Adaptação e elaboração: Gilmar Soares, 2015. 
Conforme o quadro (01), os projetos aprovados para a transferência de potencial construtivo, foram àqueles ligados à reforma e restauro de imóveis, com uma ressalva ao caso 05 deste quadro. Neste caso em específico, a reforma do "Castelinho do Conde de Sarzedas" implicou também na construção de um novo edifício da Fundação Carlos Chagas, objeto da transferência de potencial construtivo. No mais, as reformas já apontam a lógica, pelo menos para este momento atual, que caracteriza o processo de reprodução-revalorização do Centro de São Paulo através da reforma dos edifícios que estão localizados no perímetro da Operação Urbana Centro. No caso das transferências (venda) de potencial construtivo, até então realizados na Operação Urbana Centro, no caso do Hotel Jaraguá, a transferência (venda) do potencial construtivo ocorreu beneficiando uma construção nova da BANCOOP (Cooperativa habitacional dos bancários) localizada no bairro do Santana, zona norte de São Paulo.

No território da Operação Urbana Centro o coeficiente de aproveitamento é destinado aos usos residencial, residencial de uso misto (residencial e estacionamento), na construção de hotéis de turismo, às edificações cujos pavimentos são destinados à fruição pública e aos empreendimentos formados pelo remembramento de lotes (também conhecidos como land readjustment). $\mathrm{O}$ aumento do tamanho do terreno é, por conseguinte, o aumento também da capacidade de construção propiciado pelos benefícios concedidos através do coeficiente de aproveitamento 6,0. O remembramento de lotes é um incentivo à construção de novos edifícios caso haja possibilidade através do surgimento de novos terrenos, afinal, com as possibilidades postas, a tendência é que caso ocorram novos empreendimentos imobiliários, estes tendam a ter um número considerável de pavimentos. A construção de novos edifícios é também uma forma de revalorizar o espaço transformando também a paisagem.

Pela transferência de potencial construtivo, a PMSP fomenta diretamente as condições que são permissíveis e contribuem com a transformação do espaço em mercadoria. Geralmente o Estado já tem definido as condições de transferência e no Centro isso ficou evidente devido a baixa porcentagem dos projetos aprovados. Segundo o Guia para Implementação do Estatuto da Cidade (2002), o preço ${ }^{136}$ dos imóveis (no caso, o preço do $\mathrm{m}^{2}$ ) é um critério estabelecido e que deve ser levado em conta para que haja um ajuste entre lugares diferentes com preços do metro quadrado diferenciados. Por meio da transferência de potencial construtivo o Estado realiza uma mediação entre a venda e a compra destes

\footnotetext{
${ }^{136}$ No documento está posto como valor.
} 
potenciais, realizadas pelos proprietários de imóveis, controlando indiretamente a reprodução da metrópole a partir do momento que a concretização exige sua aprovação.

O Coeficiente de Aproveitamento no Centro de São Paulo, ao incentivar o tombamento de imóveis e a criação de Zonas Especiais de Preservação Cultural (ZEPEC), incentiva também o proprietário do imóvel restaurado a aproveitar o potencial construtivo deste imóvel em outro imóvel que possa estar dento ou fora do território estratégico de intervenção no Centro. Por meio do instrumento urbanístico fica evidente que o beneficiário somente pode ser o proprietário e/ou empreendedor que vê na construção de edificações as possibilidades de realização do negócio. Como no Centro o que ocorre são imóveis, portanto, prédios inteiros, que apresentam elevado número de pavimentos, consequentemente, ocorre que o potencial construtivo a ser transferido também pode ser elevado. O Coeficiente de Aproveitamento mediante transferência de potencial construtivo, como bem estabelece o guia do Estatuto da Cidade, caracteriza a transferência entre proprietários privados, entretanto é fundamental a mediação da prefeitura para poder registrar em cadastro a perda do potencial do imóvel que realizou a transferência e o aumento do potencial do imóvel receptor ${ }^{137}$. A cidade como negócio, neste caso do instrumento urbanístico, passa pela mediação do Estado, ao mesmo tempo em que caracteriza um de seus mecanismos estratégicos para a produção política do espaço.

\section{b) Contrapartida financeira para apresentação de propostas}

Correspondendo com as condições da Operação Urbana Centro, que visam o restauro de imóveis no Centro de São Paulo, e ao mesmo tempo a manutenção e reforma do patrimônio arquitetônico, a contrapartida financeira corresponde ao pagamento dos benefícios concedidos pelo Estado em que os proprietários de imóveis apresentam as propostas levando em conta as exceções à legislação de parcelamento, uso e ocupação do solo. A Concessão Onerosa de exceções à legislação compreendeu, no âmbito de aprovação das propostas enviadas à Operação Urbana Centro, àquela que mais apresentou números de envios e, consequente, de aprovação. O número elevado de propostas em relação às demais, orienta na interpretação das estratégias do Estado para a revalorização do Centro a partir das reformas e restauros de edifícios. Com demolições parciais (que exigem a manutenção do índice urbanístico da edificação), com reformas que contemplam aumento de áreas, com o aumento

\footnotetext{
${ }^{137}$ Estatuto da cidade: guia para implementação pelos municípios e cidadãos: Lei n. 10.257 , de 10 de julho de 2001, que estabelece diretrizes gerais da política urbana, 2002.
} 
da taxa de ocupação, com reformas que se realizam para atender normas de segurança, reformas para o aumento de área e também a construção de novas edificações, "a contrapartida financeira [...] refere-se aos benefícios concedidos que configuram exceção à legislação vigente, autorizadas por esta lei” (CARTILHA DA ÁREA CENTRAL, 2010, p. 20).

Ao considerarmos as demais propostas aprovadas até então - 05 para a compra de potencial e 05 para a transferência (venda) de potencial -, aquelas relacionadas à concessão de exceções à legislação correspondem às intervenções arquitetônicas que mais caracterizaram nas práticas de restauro e reforma dos imóveis no Centro de São Paulo. A ocorrência do predomínio de restauro e reformas de imóveis no território da operação urbana coaduna com que estamos discorrendo desde o primeiro capítulo desta dissertação (em que a raridade do espaço, portanto, a escassez de espaço suficiente para a construção) torna-se um fator central para se compreender as dinâmicas que caracterizam a reprodução do Centro de São Paulo. O espaço superedificado do Centro de São Paulo tornou-se, contraditoriamente, seu próprio limite para uma reprodução capitalista por meio da produção de novas unidades de edificações. A possibilidade de construção de novos edifícios capazes de produzir, por meio de formas arquiteturais e estruturas contemporâneas, um novo valor ao espaço acabou sendo impedida pela própria realidade do espaço produzido do Centro. O que resta às transferências de potencial construtivo que derivaram das obras de restauro, no que tange à construção de novos edifícios, é a construção de novas unidades fora do perímetro da operação urbana no Centro de São Paulo.

A contrapartida financeira, correspondente ao artigo $4^{\text {o }}$ da Lei 12. 349 de 06/06/1997, tem como referência para a realização alguns referenciais para a apresentação das propostas como: 1) as modificações de índices urbanísticos, as modificações também nas características de uso e ocupação do solo, e as modificações das disposições contidas no código de obras; 2) a transferência do potencial construtivo dos imóveis preservados, como foi o que ocorreu com a maioria dos casos de apresentação de propostas para a Operação Urbana Centro; 3) a regularização de construções, reformas ou ampliações executadas em desacordo com a legislação vigente, portanto, naquelas que estavam (ou poderiam estar) em caráter de embargo; e por fim, 4) por meio de cessão onerosa do espaço público aéreo ou subterrâneo levando em conta o interesse público, ou seja, do próprio Estado que, porventura, tem poder para realizar alguma desapropriação para fins de modificações, transformações no espaço. Este $4^{\circ}$ artigo apresenta um parágrafo central nas transformações que estão ocorrendo atualmente, pois, as exigências das empresas para a realização no Retrofit total dos edifícios 
no Centro de São Paulo, passam pelo questionamento de normativas que como o $2^{\circ}$ parágrafo destaca. Nele "as modificações referentes ao Código de Obras e Edificações não poderão incorrer em prejuízo das condições de estabilidade, segurança e salubridade das edificações e equipamentos" (CARTILHA DA ÁREA CENTRAL, 2010, p. 20). Tanto as normativas explicitadas na lei da Operação Urbana Centro de 1997, quanto as leis revistas no Plano Diretor Estratégico aprovado em 2014, apresentam à iniciativa privada as necessidades de revalorização mais "plausíveis" a partir do Retrofit Total.

Porém, a construção de novos empreendimentos também é incentivada no território da Operação Urbana Centro. Evidente que em função da escassez de espaços disponíveis para novos empreendimentos, raras serão as iniciativas. No caso destas, uma grande obra foi feita na Rua Augusta próximo à Praça Roosevelt, outra na Rua Consolação que está vinculada à Universidade de São Paulo, outra (na esquina da Rua Brigadeiro Tobias com a Avenida Senador Queiroz) para a construção de studios e apartamentos que vão de 30 a 60 metros quadrados. O grau de investimento em novos empreendimentos ainda é baixo, levando em conta o andamento do processo de revalorização e as estratégias que giram em torno de trazer novos habitantes (geralmente ligados à classe média) para o Centro de São Paulo. Por mais que haja a escassez de novos terrenos para a construção de novos empreendimentos, o mercado imobiliário sempre tem uma forma de buscar novos terrenos. Neste caso, os estacionamentos tornam-se uma alternativa para as empresas que buscam terrenos no Centro de São Paulo. O caso do item $n^{\circ} 24$ do quadro 02 é exemplar. O terreno era um estacionamento e foi comprado para a construção de um edifício residencial, contudo, conforme os dados do site ${ }^{138}$, ainda sem previsão de lançamento.

${ }^{138} \mathrm{http}: / /$ www.taruma.com.br/empreendimento.asp?id=183 
Quadro 2 - Operação Urbana Centro: propostas com solicitações de exceções à Lei de Parcelamento, Uso e Ocupação do Solo

\begin{tabular}{|c|c|c|c|c|c|c|c|}
\hline \multicolumn{8}{|c|}{ Solicitações de exceções a LPUOS para imóveis no perímetro da Operação Urbana Centro } \\
\hline 11 & $\begin{array}{l}\text { BM\&F - BOLSA DE } \\
\text { MERCADORIAS E FUTUROS }\end{array}$ & $1997-0.151 .774-1$ & Rua João Brícola, 37 & APROVADO. & $\begin{array}{l}\text { Edifício de Serviços; demolição parcial com } \\
\text { manutenção de índices urbanísticos. }\end{array}$ & $\begin{array}{c}\text { exceç̃̃es } \\
\text { luos }\end{array}$ & $\begin{array}{l}\text { demolição parcial com } \\
\text { manutenção de índices }\end{array}$ \\
\hline 12 & HENRIQUE BRENNER & 1992-0.003.084-0 & Rua Álvaro de Carvalho, 281 & APROVADO. & $\begin{array}{l}\text { Construção de edificação nova para serviços hoteleiros. } \\
\text { Nova solicitação: em 27/04/2012 atualização e } \\
\text { alteração da Certidão/SEMPLA/006/95. Aut uação de } \\
\text { PA n }{ }^{\circ} \mathrm{SP} \text { - Urbanismo } 117\end{array}$ & $\begin{array}{c}\text { exceções } \\
\text { luos }\end{array}$ & $\begin{array}{l}\text { Construção de edificação } \\
\text { nova para serviços hoteleiros }\end{array}$ \\
\hline 13 & \begin{tabular}{|l|} 
EBCT - EMPRESA BRASILEIRA DE \\
CORREIOS E TELÉGRAFOS
\end{tabular} & $1997-0.192 .906-3$ & Praça do Correio, S/N & APROVADO. & \begin{tabular}{|l} 
Centro Cultural reforma c/ aumento de área e \\
permissão para atividade não conforme na zona de uso.
\end{tabular} & $\begin{array}{c}\text { exceções } \\
\text { luos }\end{array}$ & $\begin{array}{l}\text { Centro cultural: reforma } \\
\text { com aumento de ârea }\end{array}$ \\
\hline 14 & $\begin{array}{l}\text { SILVIO SANT OS PARTICIPAÇÕES } \\
\text { S.A. }\end{array}$ & $1998-0.167 .800-3$ & Rua Jaceguai x R. Abolição & APROVADO. & $\begin{array}{l}\text { Centro de serviços de lazer e comercial: aumento da } \\
\text { TO; dispensa do atendimento de recuos. } \\
\end{array}$ & \begin{tabular}{|c|}
$\begin{array}{c}\text { exceções } \\
\text { luos }\end{array}$ \\
\end{tabular} & $\begin{array}{l}\text { aumento da taxa de } \\
\text { ocupação }\end{array}$ \\
\hline 15 & $\begin{array}{l}\text { ANTONIO CARLOS COST A } \\
\text { ARANHA E OUT ROS }\end{array}$ & $1998-0.225 .711-7$ & $\begin{array}{l}\text { Rua Barão de Parapiacaba, 73- } \\
83\end{array}$ & APROVADO & $\begin{array}{l}\text { Edifício de Serviços; reforma c/ aumento de área de } \\
\text { edif. }\end{array}$ & $\begin{array}{c}\text { exceções } \\
\text { luos }\end{array}$ & $\begin{array}{l}\text { reforma com aumento da } \\
\text { edificação }\end{array}$ \\
\hline 16 & \begin{tabular}{|l|} 
TRIBUNAL REGIONAL \\
ELEITORAL \\
\end{tabular} & $1998-0.247 .237-9$ & Rua Francisca Miquelina,123 & \begin{tabular}{|l} 
APROVADO \\
$05 / 09 / 01$
\end{tabular} & $\begin{array}{l}\text { Edifício Institucional; regularização e reforma com } \\
\text { aumento de área de edificação situada na OU Centro. }\end{array}$ & \begin{tabular}{|c|}
$\begin{array}{c}\text { exceções } \\
\text { luos }\end{array}$ \\
\end{tabular} & $\begin{array}{l}\text { regularização e reforma com } \\
\text { aumento da edificação }\end{array}$ \\
\hline 17 & $\begin{array}{l}\text { BM\&F - BOLSA DE } \\
\text { MERCADORIAS E FUT UROS }\end{array}$ & $1998-0.248 .098-3$ & Rua João Brícola, 37 & APROVADO. & Edifício de Serviços; reforma com aumento de área. & $\begin{array}{c}\begin{array}{c}\text { exceções } \\
\text { luos }\end{array} \\
\end{array}$ & $\begin{array}{l}\text { reforma com aumento da } \\
\text { edificação }\end{array}$ \\
\hline 18 & $\begin{array}{l}\text { TRIBUNAL DE JUST IÇA DO } \\
\text { EST ADO DE SP }\end{array}$ & $2005-0.274 .107-0$ & $\begin{array}{l}\text { Rua Conde de Sarzedas x R. } \\
\text { Cons. Furtado x R. } \\
\text { Tabatingüera x Pça João } \\
\text { Mendes }\end{array}$ & APROVADO & $\begin{array}{l}\text { Edifício de Serviços; obra nova com solicitação de } \\
\text { aumento de potencial construtivo e exceções à LUOS. } \\
\text { ARQUIVO_JL } 2013\end{array}$ & $\begin{array}{c}\text { exceç̃̃es } \\
\text { luos }\end{array}$ & $\begin{array}{l}\text { Obra nova com solicitação } \\
\text { de aumento de potencial } \\
\text { construtivo }\end{array}$ \\
\hline 19 & ROBERTO ELIAS CURY & $2007-0.099 .210 .0$ & Rua São Bento, 51 & APROVADO. & $\begin{array}{l}\text { Regularização de edificação e reforma para adequação } \\
\text { de normas de segurança }\end{array}$ & \begin{tabular}{|c|} 
exceç̃̃es \\
luos
\end{tabular} & $\begin{array}{l}\text { regularização, reforma e } \\
\text { adequação }\end{array}$ \\
\hline 20 & $\begin{array}{l}\text { BROOKFIELD SÃO PAULO } \\
\text { EMPREENDIMENT OS } \\
\text { IMOBILIÁRIOS } \\
\end{array}$ & $2011-0.0 .070 .237-3$ & $\begin{array}{l}\text { Rua Augusta } 101 \text { a } 185 \mathrm{com} \\
\text { Rua Caio Prado }\end{array}$ & APROVADO & $\begin{array}{l}\text { Serviços profissionais (escritórios) e serviços de } \\
\text { hospedagem (flats). }\end{array}$ & $\begin{array}{l}\text { exceções } \\
\text { luos }\end{array}$ & Obra nova \\
\hline 21 & $\begin{array}{l}\text { ANTONIO MARCOS de AGUIRRA } \\
\text { MASSOLA / USP }\end{array}$ & $2012-0.100 .423-0$ & Rua da Consolação 268 & APROVADO & $\begin{array}{l}\text { Proposta de construção de Edificação nova para } \\
\text { atividade sóciocultural da USP Benefício Aprovado: } \\
\text { Potencial Construtivo Adicional: } \mathbf{3 . 1 5 6 , 7 6} \mathbf{~ m}^{2} \\
\text { para a subcategoria de uso nR3 (serviço sócio } \\
\text { cultural); Valor da Contrapartida: de } \$ \text { \$ } \\
\mathbf{2 . 3 0 5 . 8 5 6 , 4 5}\end{array}$ & $\begin{array}{l}\text { exceções } \\
\text { luos }\end{array}$ & Obra nova \\
\hline 22 & $\begin{array}{l}\text { ORDEM DOS ADVOGADOS DO } \\
\text { BRASIL / SEÇÃO SÃO PAULO }\end{array}$ & $2012-0.181 .101-1$ & $\begin{array}{l}\text { Rua Maria Paula 23, 29, } 35 \mathrm{cl} \\
\text { Brig. Luís Antônio, 258 } \\
\end{array}$ & APROVADO & $\begin{array}{l}\text { Reforma com aumento de área de edifício de } \\
\text { escritórios. }\end{array}$ & \begin{tabular}{|c|}
$\begin{array}{c}\text { exceções } \\
\text { luos }\end{array}$ \\
\end{tabular} & $\begin{array}{l}\text { reforma com aumento da } \\
\text { edificação }\end{array}$ \\
\hline 23 & $\begin{array}{l}\text { SERGIO D’ANDRADA DE } \\
\text { ALMEIDA }\end{array}$ & $2012-0.235 .497-8$ & $\begin{array}{l}\text { Rua Brigadeiro Tobias, } \\
466,470,478 \text { e } 490 \\
\end{array}$ & APROVADO & $\begin{array}{l}\text { Edificação nova de uso misto: R2v (incentivado ) e } \\
\text { comércio }\end{array}$ & $\begin{array}{c}\begin{array}{c}\text { exceções } \\
\text { luos }\end{array} \\
\end{array}$ & Obra nova \\
\hline 24 & HENRIQUE BRENNER & 2012-0.178.957-1 & $\begin{array}{l}\text { Rua Major Quedinho x Rua } \\
\text { Álvaro de Carvalho, } 281\end{array}$ & APROVADO & $\begin{array}{l}\text { Construção de edifício residencial, utilizando direito de } \\
\text { Certidão obtida através do PA SP -Urbanismo } 02\end{array}$ & \begin{tabular}{|c|} 
exceç̃̃es \\
luos
\end{tabular} & Obra nova - residencial \\
\hline
\end{tabular}

Fonte: Prefeitura Municipal de São Paulo

SP - URBANISMO. Operação Urbana Centro

Quadro de propostas apresentadas.

Adaptação e elaboração: Gilmar Soares, 2015. 
Levando em conta a solicitação de exceções a Lei de Parcelamento, Uso e Ocupação do Solo, observa-se que a maioria das solicitações ainda gira em torno de demolições parciais para a construção (ou reconstrução) de uma parcela dos edifícios. A falta de espaços disponíveis para as intervenções no Centro de São Paulo exigem que a norma da operação urbana se adeque à realidade do espaço. A tendência é que novos lançamentos imobiliários, pelo menos neste momento e nos anos seguintes, acabem sendo uma espécie de empreendimentos pioneiros que visam trazer novos moradores, geralmente pertencentes à classe média. Por enquanto, em meio a escassez de espaços, aqueles disponíveis fazem a chamada para um tipo específico de morador que coadune com as estratégias para a revalorização do espaço.

A condição atual de ser um espaço superedificado fez do Centro de São Paulo um fragmento da metrópole atravessado por esta contradição atual, afinal, ela somente explicitase enquanto um entrave para o capital a partir do momento em que a produção do espaço torna-se uma atividade produtiva significativa à reprodução do capital. A saída passa a ser então as reformas completas nos edifícios que, em muitos casos, estão deteriorados como um processo natural do tempo. As próprias condições da metrópole, do país e das relações entre as classes sociais, diretamente ou indiretamente, tornam-se um impeditivo para que tudo venha ser posto abaixo para um novo processo construtivo.

No Centro de São Paulo, como podemos perceber nos quadros (01 e 02), as poucas propostas aprovadas que foram direcionadas à SP-URBANISMO para a Operação Urbana Centro, foram propostas que visavam a reforma das edificações. Poucos foram os casos em que novas edificações foram construídas no Centro com as normativas da operação urbana. $\mathrm{O}$ artigo $5^{\circ}$ da lei da Operação Urbana Centro assegura as condições de reforma e manutenção para valorização de imóveis. Nele, um dos aspetos urbanísticos consiste na "valorização arquitetônica e ambiental dos imóveis a preservar e [seus] respectivos logradouros ${ }^{139 ",}$ (CARTILHA DA ÁREA CENTRAL, 2010, p. 20). A valorização dos imóveis exige, conforme está posto na norma, a própria valorização do espaço, a partir do momento em que as concessões mediante contrapartida financeira executem também as obras de melhoria urbana na área delimitada. A norma da operação urbana, ao invés de promover o processo de urbanização democrático, conforme esteve assegurado no próprio Estatuto da Cidade e seus promotores, ao contrário, promoveu todas as condições necessárias para que os empreendimentos lançados somente o fossem em condição de valorização. Os investimentos

${ }^{139}$ Meus grifos. 
na edificação também exigem investimentos no próprio lugar qual ela está localizada e, assim, o próprio lugar também passa pelo processo de valorização; levando em conta a edificação no Centro de São Paulo, tendencialmente, sua valorização e a valorização do lugar qual esta se encontra, também constitui uma dimensão da revalorização (nos termos da produção de um novo valor para ser vendido) do Centro de São Paulo. Até então, somente um empreendimento de grande porte da Brookfield São Paulo se destoa da maioria das propostas e, mesmo assim, sua localização contribui - nas imediações da Rua Augusta com Caio Prado, próximo a Praça Roosevelt num fragmento entre o Centro e a Bela Vista - pois este fragmento da metrópole vem recebendo muitos lançamentos de empreendimentos nos últimos anos. Ocorre que, até mesmo para a contrapartida financeira na apresentação de propostas, aquelas que foram aprovadas são, em grande maioria, aquelas voltadas às reformas de edifícios inteiros no Centro de São Paulo. De certa forma, isso pode até mesmo ser estratégico para ações futuras e álibis futuros de "(des)proletatização" desta fragmento da metrópole.

\section{c) Potencial construtivo e restauração dos imóveis}

O incentivo para a restauração de imóveis no Centro de São Paulo por meio da transferência de potencial construtivo tem como seu mecanismo o próprio valor equivalente, ou seja, o que leva em conta os cálculos e preços do metro quadrado no território da Operação Urbana Centro. O valor de equivalência da operação urbana no Centro de São Paulo corresponde ao preço do metro quadrado neste perímetro. Assim, a título de exemplo, suponhamos que há no território que abrange a intervenção urbana um imóvel em estado de "preservação" e que o mesmo apresenta como área de terreno $150.000 \mathrm{~m}^{2}$. Considerando também que o coeficiente de incentivo é igual a 6,0, como uma estratégia para atração de investidores imobiliários no Centro de São Paulo. Levando em conta que são os edifícios que passam a ser o parâmetro de realização dos cálculos, os mesmos apresentam elevados índices de metro quadrado construído. A restauração de imóveis que incentiva o potencial construtivo por meio de transferência, no caso da Operação Urbana Centro, tem um cálculo específico ${ }^{140}$ :

$$
\begin{aligned}
& \mathrm{ACe}=(\mathrm{VTp} / \mathrm{VTc}) \times(\mathrm{CAc} / \mathrm{CAp}) \times \mathrm{PCpt} \\
& \mathrm{ACe}=\text { área construída equivalente para o imóvel cessionário } \\
& \mathrm{VTp}=\text { valor do metro quadrado do terreno do imóvel preservado constante da } \\
& \text { Planta Genérica de Valores }
\end{aligned}
$$

${ }^{140}$ Conforme o cálculo sugerido na Cartilha da Área Central (2010). 
VTc = valor do metro quadrado do terreno do imóvel cessionário constante da Planta Genérica de Valores

CAc = coeficiente de aproveitamento máximo da zona de uso do imóvel cessionário $\mathrm{PCpt}=$ potencial construtivo passível de transferência em metros quadrados

No Centro de São Paulo, e nos conformes da Operação Urbana, o Hotel Jaraguá talvez tenha sido um dos primeiros imóveis Retrofit a transferir o potencial construtivo para outras obras na cidade de São Paulo. Com $30 \mathrm{mil} \mathrm{m}^{2}$ de área construída que abrange integralmente o terreno, o Hotel Jaraguá localiza-se na fração da rua onde o metro quadrado equivale (ou equivalia) no $\mathrm{PGV}^{141}$ de 2010 o total de $\mathrm{R} \$ 1.914,00$. Conforme os dados de movimentação das propostas da Operação Urbana Centro, a transferência de potencial construtivo, adquirida com a reforma do Hotel, foi realizada para um novo empreendimento que está localizado na Rua Conselheiro Moreira de Barros, no bairro do Santana, Zona Norte de São Paulo. Nesta rua, de acordo com a PGV de 2010, o metro quadrado equivalia (ou ainda equivale) ao total de $\mathrm{R} \$ 461,00$ o preço mais elevado. Mesmo que neste caso a área construída, no caso do imóvel que passou a ser preservado, seja equivalente a 12 vezes maior que a área do lote, o cálculo da venda girará em torno de $40 \%$; caso contrário (de no caso exceder 12 vezes a área do terreno) a transferência somente será possível em $40 \%^{142}$. Independente de serem $40 \%$ ou $60 \%$ - neste caso, uma diferença significativa com as arrecadações de venda de potencial construtivo - o fato do preço do $\mathrm{m}^{2}$ ser equivalente ao território da Operação Urbana Centro, faz com que este seja maior que o de alguns outros lugares da metrópole. Assim, o diferencial em metragens se potencializa no diferencial de dinheiro arrecadado com a venda do potencial construtivo.

A partir do momento que a construção de edificações em alguns lugares permite a possibilidade de obtenção de rendimentos com a transferência (ou mesmo a venda ${ }^{143}$ ) de potencial de construção, as próprias negociações que giram em torno da construção civil ganham potência de realização por meio de uma produção cada vez mais capitalista do espaço urbano. Apesar dos poucos casos (apenas cinco por enquanto), as situações em que houveram transferência de potencial para os lugares fora da Operação Urbana Centro corresponderam a venda destes potenciais para dois empreendimentos que ficam no bairro de Moema, dois na Vila Mariana, ambos zona sul de São Paulo, e uma no bairro de Santana, zona norte. Assim, a transferência do potencial construtivo como um valor equivalente aquele da Operação Urbana

\footnotetext{
${ }^{141}$ Planta Genérica de Valores, PREFEITURA MUNICIPAL DE SÃO PAULO, 2010.

${ }^{142}$ Conforme a segunda condição do artigo $7^{\circ}$ da Lei 12.349 que institui a Operação Urbana Centro.

${ }^{143}$ Caso o potencial construtivo possa beneficiar outras empresas que não aquela que é portadora inicial.
} 
Centro consiste numa maneira de incentivar por meio da garantia de rendimentos, independente do preço do metro quadrado de outros lugares da cidade, levando em conta a certeza a partir do preço do metro quadrado do solo no território de intervenção da operação urbana.

A nomenclatura utilizada pela PMSP para estas operações correspondem a transferência, contudo, numa análise mais atenta, a tendência que se confirma e pode se reforçar ainda mais, consiste no aumento das práticas de reformas de edifícios inteiros mediante, também, as possibilidades de obtenção de rendimentos advindos da transferência de potencial construtivo. A Prefeitura, constantemente, controla a liberação de estoques para serem comprados pelas empresas ligadas a indústria do imobiliário em São Paulo. A relação entre o total de estoques liberados e aqueles que estão comprometidos, determinam o panorama possível a partir dos estoques que estão disponíveis para compra mediante a outorga onerosa do direito de construir. Entre os distritos que compõem a área central da cidade de São Paulo, a disponibilidade de estoques liberados pela PMSP aponta um panorama de direcionamento do processo de urbanização.

Tabela 3 - Estoques disponibilizados nos distritos da área central

\begin{tabular}{c|r|r|r}
\hline Distrito & $\begin{array}{c}\text { Total Estoque } \\
(\mathbf{m} 2)\end{array}$ & $\begin{array}{c}\text { Comprometido } \\
(\mathbf{m 2})\end{array}$ & Disponível (m2) \\
\hline Brás & $90.000,00$ & 0,00 & $90.000,00$ \\
\hline Pari & $80.000,00$ & $10.116,42$ & $69.883,58$ \\
\hline Sé & $40.000,00$ & 0,00 & $40.000,00$ \\
\hline República & $20.000,00$ & 0,00 & $20.000,00$ \\
\hline Consolação & $80.000,00$ & $75.069,62$ & $4.930,38$ \\
\hline Bom Retiro & $40.000,00$ & $38.272,47$ & $1.727,53$ \\
\hline Liberdade & $25.000,00$ & $24.951,06$ & 48,94 \\
\hline Bela Vista & $50.000,00$ & $49.973,49$ & 26,51 \\
\hline Cambuci & $20.000,00$ & $19.999,92$ & 0,08 \\
\hline Santa Cecília & $90.000,00$ & $90.000,00$ & 0,00 \\
\hline
\end{tabular}

Fonte: Prefeitura Municipal de São Paulo Organização e elaboração: Gilmar Soares, 2015.

O potencial construtivo, seja ele liberado pelo Estado para ser comprado ou seja ele conseguido por meio de reformas e restauros, torna-se e tende, a cada vez mais, se constituir como um mecanismo de valorização (e segregação) que pode ganhar "vida própria" e formas de alienação no mercado. O parágrafo terceiro do artigo $7^{\circ}$ evidencia a relação (de maneira não tão clara) em sua exposição: "a transferência de que trata este artigo poderá ser total, parcial ou realizada em etapas, e ser feita para um ou mais imóveis, pertencente a um ou mais 
proprietários $^{144}$ ". O fato da Operação Urbana Centro não ser consorciada, põem de imediato esta questão. Enquanto os CEPAC's são emitidos e se valorizam em sua circulação própria, nas intervenções onde não há os certificados emitidos pelo Estado e negociados na bolsa, a relação de compra e venda (quando existe) passa a ser direta.

No território urbanístico que compreende a Operação Urbana Centro, há zonas específicas ligadas à proibição de transferência de potencial para estas que, por ventura, são aquelas mais adensadas. Assim, levando em conta a necessidade de restauração do imóvel preservado $^{145}$, está explícito no parágrafo sexto do artigo $7^{\circ}$ que os projetos de restauração e conservação dos imóveis [...] deverão ser aprovados pela Secretaria Municipal de Cultura SMC e, o caso dos imóveis classificados como Z8-200, também pela Secretaria Municipal de Planejamento - SEMPLA. Além de ser uma estratégia política para a revalorização do Centro de São Paulo, a cultura, por meio de sua secretaria municipal, passa a ser também um dos agentes responsáveis para a liberação de restauro de imóveis e, direta ou indiretamente, a responsável também pelos trâmites de liberação da transferência de potencial construtivo entre os proprietários de imóveis. Além das duas secretarias, a liberação também fica a cargo da antiga CNLU e atual CTLU.

A complexidade cada vez maior do processo de urbanização, além de refletir no movimento da reprodução da metrópole (ao absorver os conteúdos da forma-mercadoria, como também caracterizado com capital fixo e força produtiva), reflete também as transformações que são exigidas nas próprias instituições do Estado, que podem ser observados no conjunto de órgãos, normas, recursos humanos e técnicos. Para se adaptar as novas exigências que imprimem, cada vez mais, os traços da urbanização capitalista no espaço, a Prefeitura Municipal de São Paulo cria as empresas específicas para estas atividades na cidade de São Paulo. Estas empresas, ao gerir com a eficiência esperada as ferramentas e mecanismos dos instrumentos urbanísticos, acabam invertendo o sentido que alguns bons urbanistas esperavam no tocante a urbanização democrática da cidade. Contudo, a potência que o processo de urbanização guarda em si - em ser uma válvula de escape às crises de acumulação e ao mesmo tempo movimentar quantias significativas de dinheiro e possibilidades de continuidade da acumulação - fazem deste um processo, por excelência, de reprodução do capital a partir da reprodução do espaço. Assim, numa relação entre prefeitura, capital e espaço, a reprodução da cidade ganha centralidade nas formas de acumulação, pois,

\footnotetext{
${ }^{144}$ CARTILHA DA ÁREA CENTRAL, 2010, p. 21.

${ }^{145}$ Ibidem.
} 
as características principais dos mecanismos que direcionam o processo ${ }^{146}$ são aquelas que permitem formas de negociações que surgem dos próprios mecanismos que direcionam o processo de urbanização. Os órgãos municipais responsáveis pela urbanização capitalizada em São Paulo, acabam sendo aqueles que foram transformados em empresas, como bem “mandam" as leis que caracterizam as reformas do Estado na década de 1990.

Assim, no Centro de São Paulo, principalmente nos distritos com maior grau de edificações (Sé e República), o potencial construtivo se realiza nas obras que visam o restauro ou a reforma total dos imóveis, por meio da preservação da sua estrutura arquitetônica. A reforma e/ou restauro incentivados pela transferência de potencial torna-se um mecanismo que permite ao proprietário e ao investidor a realização de novos negócios voltados à produção imobiliária e, por conseguinte, à produção do espaço, já que, como vimos, a contrapartida também se realiza nas obras que ficam no entorno da edificação.

Atravessando a estrutura destes mecanismos e determinando suas funções, o preço do metro quadrado do espaço, assim como também as estratégias para sua valorização, revelam a verdadeira faceta da urbanização na atualidade. Há lugares na metrópole que são estratégicos $\mathrm{e}$, à luz dos empreendedores e investidores do mercado imobiliário, tornam-se excelentes condições que tendencialmente possam se realizar enquanto uma nova fronteira de acumulação, devido ao espaço qual se localizam e ao mesmo tempo os caracteriza. Por meio dos instrumentos urbanísticos o Estado contribui com esta trajetória em que a liberalização de parcelas do espaço para o mercado constitui, significativamente, a produção da segregação socioespacial onde tanto a cidade quanto a vida urbana se realizam também enquanto valor de troca.

O atual estágio da Operação Urbana Centro no contexto estratégico da Prefeitura Municipal de São Paulo

Na Lei $\mathrm{n}^{\mathrm{o}} 16.050$ de 31 de Julho de 2014, que dispõe sobre a Politica de Desenvolvimento Urbano, o Sistema de Planejamento Urbano e o Plano Diretor Estratégico do Município de São Paulo, a Operação Urbana Centro adquire um destaque especial no que tange a totalidade das intervenções espaciais que estão postas (ou já se encontram em realização) ao movimento de reprodução da metrópole. Compondo um dos três setores (considerados agregados a partir de dez subsetores distintos), a Operação Urbana Centro

\footnotetext{
${ }^{146}$ Sobre a Operação Urbana Centro verificamos o coeficiente de aproveitamento, a transferência do potencial construtivo e a outorga onerosa do direito de construir e de superficie.
} 
através de seu território atual, organiza o que é considerado como Setor Central ${ }^{147}$. A fragmentação instrumental do espaço acaba sendo a principal característica da estratégia de "Estruturação Metropolitana", pois, uma macroárea que norteia as intervenções na metrópole foi delimitada em função dos

processos de mudanças nos padrões de uso e ocupação e conversão econômica, com concentração de oportunidades de trabalho e emprego geradas pela existência de legados industriais herdados do passado, novas atividades produtivas, polos de atividades terciarias, grandes vias estruturais e infraestruturas que fazem parte dos sistemas de transporte coletivo de massa (PLANO DIRETOR ESTRATÉGICO, 2014).

A dimensão concreta da produção do espaço revela também a concretude da dimensão política por meio das estratégias do Estado, através de novas modalidades que atravessam as formas de ocupação do espaço em que as especialidades e especializações (zoneamentos e zonas específicas, delimitadas conforme os perfis e classes sociais que ocupam este espaço) são capazes de funcionalizar cada vez mais estes espaços e seus respectivos lugares. Ou seja, em seu atual contexto, a Prefeitura, munida dos instrumentos urbanísticos possíveis, delimita estrategicamente os territórios que passarão por intervenções na metrópole. Por meio da articulação dos planos estratégicos (Plano Diretor, Planos regionais, Lei de Parcelamento, Uso e Ocupação do solo, Lei Orgânica do Município etc.) as estratégias são amarradas, como se pudesse caracterizar o caráter homogeneizante das ações do Estado. Ao se inserir nestes espaços, o Estado quebra as oposições que nele germinam, quebra as possibilidades de reversão em que, necessariamente, faz com que espaços diferenciais sejam produzidos. Ao mesmo tempo em que o Estado se insere e despotencializa o negativo, ele também hierarquiza os lugares, de forma que este processo também contribui diretamente com a valorização diferenciada dos lugares.

Plano Diretor e Plano Regional ${ }^{148}$ surtem como um amálgama na articulação de políticas de delimitação de territórios para as intervenções no espaço. Eles determinam os objetivos estratégicos traçados para o espaço, determinam as frentes de intervenção, os procedimentos e recursos que caracterizam as intervenções. Além das determinações que

\footnotetext{
${ }^{147}$ Conforme o artigo 12 do Plano Diretor Estratégico aprovado em 2014, o território da Operação Urbana Centro e seu entorno organizam aquele que é considerado o Setor Central. Este, por sua vez, consiste em um dos três setores que compõem a Macroárea de Estruturação Metropolitana que direcionam as intervenções na reprodução da metrópole.

${ }^{148}$ Neste caso levando em conta o Plano Diretor Estratégico e o Plano Regional Estratégico da Subprefeitura Sé.
} 
coadunam com as estratégias da iniciativa privada que investem no espaço, os planos também servem como direcionadores das ações que se articulam com outros planos.

Os objetivos específicos (uma espécie de conjunto de "metas" a serem alcançadas, para o setor central) que formam postos para o Setor Central nessa Macroárea de Estruturação Metropolitana, consistem em aspectos como o aproveitamento da infraestrutura existente, de certa forma "abundante", como não ocorrem em outros lugares da cidade. Somados ao fator infraestrutural, há também a exploração das potencialidades econômicas que derivam da localização destes espaços na metrópole. O Macroeixo aponta o devir das políticas urbanoterritoriais na metrópole, as estratégias postas e nelas o Centro de São Paulo, reconhecido a partir da Operação Urbana em seu território, torna-se um referencial para este fragmento da cidade.

Quadro 3 - Relação entre a Operação Urbana Centro, o Setor Central e a Macroárea De Estruturação Metropolitana

\begin{tabular}{|c|c|c|}
\hline \multicolumn{3}{|c|}{ Os objetivos específicos da Macroárea de Estruturação Metropolitana no Setor Central } \\
\hline 01 & $\begin{array}{l}\text { Fortalecimento do caráter } \\
\text { de centralidade } \\
\text { municipal }\end{array}$ & $\begin{array}{l}\text { Aumentando a densidade demográfica e a oferta habitacional, } \\
\text { respeitando o patrimônio histórico, cultural e religioso, otimizando a } \\
\text { oferta de infraestrutura existente; renovando os padrões de uso e } \\
\text { ocupação e fortalecendo a base econômica local; }\end{array}$ \\
\hline 02 & $\begin{array}{l}\text { Valorização das áreas de } \\
\text { patrimônio cultural }\end{array}$ & $\begin{array}{l}\text { Com a proteção e recuperação de imóveis e locais de referência da } \\
\text { população da cidade, estimulando usos e atividades compatíveis com a } \\
\text { preservação e sua inserção na área central; }\end{array}$ \\
\hline 03 & $\begin{array}{l}\text { Qualificação da oferta de } \\
\text { diferentes sistemas de } \\
\text { transporte coletivo }\end{array}$ & $\begin{array}{l}\text { Articulando-os aos modos não motorizados de transporte e promovendo } \\
\text { melhorias na qualidade urbana e ambiental do entorno; }\end{array}$ \\
\hline 04 & $\begin{array}{l}\text { Estímulo à provisão } \\
\text { habitacional de interesse } \\
\text { social }\end{array}$ & $\begin{array}{l}\text { Social para a população de baixa e média renda de modo a aproximar a } \\
\text { moradia do emprego; }\end{array}$ \\
\hline 05 & $\begin{array}{l}\text { Requalificação e } \\
\text { reabilitação das áreas } \\
\text { deterioradas e } \\
\text { subutilizadas }\end{array}$ & $\begin{array}{l}\text { Ocupadas de modo precário pela população de baixa renda, como } \\
\text { cortiços, porões, quitinetes e moradias similares, em bairros como } \\
\text { Glicério, Cambuci, Liberdade, Pari, Canindé, Brás, entre outros; }\end{array}$ \\
\hline 06 & $\begin{array}{l}\text { Redefinição dos } \\
\text { parâmetros de uso e } \\
\text { ocupação do solo }\end{array}$ & $\begin{array}{l}\text { Que promovam mescla e maior proximidade de diferentes tipologias } \\
\text { residenciais para grupos de baixa, média e alta renda; }\end{array}$ \\
\hline 07 & $\begin{array}{l}\text { Operação Urbana } \\
\text { Centro }\end{array}$ & Revisão e atualização da Operação Urbana Centro; \\
\hline 08 & $\begin{array}{l}\text { Instituição de programas } \\
\text { de requalificação } \\
\text { urbana e integração entre } \\
\text { os usos residenciais e não } \\
\text { residenciais }\end{array}$ & $\begin{array}{l}\text { Para vários subsetores da área central, considerando-se os usos não } \\
\text { residenciais e suas especialidades, entre elas, a zona cerealista, a área da } \\
\text { Rua } 25 \text { de Março, o Mercado Municipal. }\end{array}$ \\
\hline
\end{tabular}

Fonte: Prefeitura Municipal de São Paulo

Plano Diretor Estratégico, 2014.

Elaboracão e adaptacão: Gilmar Soares. 2015. 
Todavia, enquanto um fragmento da metrópole que tende a uma nova fronteira de acumulação, o Centro (considerado nos distritos Sé e República) e os distritos do seu entorno, neste momento, tornam-se uma espécie de gargalo à revalorização do espaço. Por mais que portem este potencial avaliado por meio da concentração de infraestruturas e equipamentos urbanos, há o "impasse" da propriedade privada do solo urbano (ou propriedade privada do espaço) e do adensamento ainda maior da ocupação proletária em boa parte de seus lugares. A Operação Urbana Centro, criada em 1997, surgiu neste movimento em que a revalorização exigia-se (conforme havia em concomitância) a reversão do processo de intensificação da apropriação proletária do Centro de São Paulo. Ao centralizar em sua forma outras demais políticas urbano-territoriais (como foi o caso do PROCENTRO, da Concessão Urbanística "Nova Luz", da PPP Casa Paulista, e de uma relação bem próxima com o “Arco do Tietê"), a Operação Urbana Centro centraliza e torna-se o maior referencial para o processo de revalorização deste fragmento da metrópole. Das políticas urbano-territoriais mencionadas acima, o PROCENTRO já encerrou suas atividades e a Concessão Urbanística "Nova Luz" acabou sendo embargada pela justiça. Ligada diretamente à Operação Urbana Centro, estão somente a PPP Casa Paulista e, de maneira indireta, o "Arco do Tietê".

\subsubsection{PROCENTRO}

Alguns estudos ${ }^{149}$ sobre o PROCENTRO foram realizados sob as mais diversas situações de interpretação desta política e sua intervenção no espaço urbano. O rumo tomando por estas pesquisas foi de comparar suas realizações e suas propostas e destacar o descompasso daquilo que foi proposto com aquilo que vinha sendo realizado, bem como se dava o andamento das intervenções conforme mudou os mandatos na Prefeitura. Outro fator de destaque corresponde a análise do papel do BID (Banco Interamericano de Desenvolvimento) e as cobranças pela sua "ausência" de uma espécie de fiscalização, que fosse capaz de garantir o caráter social da política ${ }^{150}$.

Entre as pesquisas que tivemos a oportunidade de analisar sobre o PROCENTRO, observamos que em cada uma havia uma maneira de discorrer sobre o andamento da

\footnotetext{
${ }^{149}$ Esquinca (2013), Sombni (2013), Neves (2012), Colvero (2010), Viana (2009), Motisuke (2008), Cymbalista et al (2008), Leirner (2006) entre outros.

${ }^{150}$ Este aspecto pode ser observado no conjunto dos trabalhos que foram desenvolvidos junto ao Programa de Pós-Graduação em Administração Pública e Governo, que, em sua grande maioria, foram orientados pelo Professor Francisco Fonseca. A maioria destas pesquisas buscou analisar a dinâmica do capitalismo contemporâneo através das respostas do Estado, conforme nos alerta Neves (2012).
} 
política $^{151}$. No caso desta pesquisa, as considerações sobre o PROCENTRO correspondem com o seu curso e suas intervenções no processo de revalorização do Centro de São Paulo. Vale salientar, antes das demais considerações, que esta política teve como território de atuação os próprios recortes dos distritos na área central da cidade de São Paulo; o que a diferencia das outras políticas que se realizam através de um território estratégico específico. Contudo, ao longo do tempo e já em seu período final, o PROCENTRO, enquanto medida política de intervenção na área central, manteve uma breve articulação com o conjunto de políticas que foram vinculadas a Operação Urbana Centro.

A "primeira versão" do PROCENTRO foi decretada no ano de 1993, sob a gestão do prefeito Paulo Maluf. Naquele momento, o PROCENRO consistia num programa de requalificação urbana e funcional do Centro de São Paulo que tinha como território de implantação uma área especial de intervenção compreendendo basicamente os distritos Sé e República. Teve como pressupostos-chave: 1) a importância simbólica do Centro aliada a seu significado histórico, cultural, arquitetônico e econômico; 2) a implementação de ações que assegurassem melhor condição ambiental e que ao mesmo tempo prevenissem a deterioração e a desvalorização imobiliária da área; 3) promover a ordenação da paisagem urbana da Cidade de São Paulo, com a adoção de uma política de revalorização de sua área central; 4) propiciar melhores condições para os usos existentes na área e outros a serem efetivados. De acordo com o estudo do Instituto Polis, esse primeiro momento do PROCENTRO foi caracterizado mais pelos ajustes de criação da comissão executiva ${ }^{152}$, pela busca da consolidação do programa, bem como pela ampliação do discurso para o financiamento externo.

O histórico das intervenções na cidade de São Paulo, somado ao elevado custo de realização destas intervenções, já rebatia em governos anteriores. O resultado foi que, ao longo do tempo, as medidas que se tornaram viáveis foram aquelas que se realizaram por meio da parceria entre o setor público e o setor privado. Essa necessidade de apelo ao setor

\footnotetext{
${ }^{151}$ Por exemplo, os estudos do PROCENTRO que são realizados pelo Instituto Polis são caracterizados pela discussão acerca da moradia social no Centro, como também na a ausência da participação pública na elaboração da política. Os estudos sobre o PROCENTRO, realizados no Programa de Pós-Graduação em Administração Pública e Governo (Fundação Getúlio Vargas), concatenam com uma análise pormenorizada da política em função de parâmetros que são postos como "certo ou errado", "legais ou ilegais", na execução desta política de Estado.

${ }^{152}$ A comissão executiva do programa está elencada no Decreto $n^{\circ} 33.390$, de 14 de Julho de 1993. O decreto, que considera a necessidade de um gerenciamento único na área do programa, exige que se estipulem regras coerentes e ações coordenadas de todos os órgãos e entidades envolvidas na intervenção. São eles: 1) Secretaria de Habitação e Desenvolvimento; 2) Secretaria Municipal de Cultura - SMC; 3) Secretaria Municipal de Planejamento; 4) Secretaria de Administrações Regionais - SAR; 5) Companhia de Engenharia de Tráfego CET; 6) Empresa Municipal de Urbanização - EMURB; 7) Associação Viva Centro; 8) Sindicato das Empresas de Publicidade Exterior do Estado de São Paulo - SEPEX.
} 
privado decorre da própria necessidade do capital buscar no Estado e nas possibilidades de produção do espaço as condições necessárias de continuidade da acumulação.

As circunstâncias históricas exigiram que neste momento houvesse, por parte do Estado, uma nova maneira de intervir, criando condições que fossem necessárias a intervenção da iniciativa privada no espaço. Ao criar estas condições por meio de normas e leis, os Estados operam normativamente no sentido de garantir por meio da forma normativa a garantia política das condições de reprodução, consolidando e aperfeiçoando as formas de dominação. As condições postas para o PROCENTRO surgem em função de este fragmento da cidade já estar caracterizado pelas representações da deterioração, expressivas em sua paisagem. Os discursos sobre o espaço desvalorizado, ao se rebaterem no Estado, foram responsáveis por constituir mecanismos específicos de leis e intervenções, bem como, posteriormente, algumas formas de fomento. Por meio dos mecanismos de elaboração das normas e leis, postos em prática pelo Estado, as intervenções no espaço também se adaptam às condições específicas que geralmente surgem da própria realidade em que ocorrem as disputas pelo espaço.

Nesse primeiro momento do PROCENTRO, as especializações e ajustes da política ocorreram conforme os anseios da primeira comissão executiva, da qual participaram, dentre os membros ligados as entidades de Estado, aqueles ligados à Associação Viva Centro. Os primeiros quatro anos do PROCENTRO, correspondentes à gestão de Paulo Maluf, foram de fortalecimento dos laços institucionais da PMSP (que representava o programa de intervenção) com outros órgãos de auxílio, como a FIPE - Fundação Instituto de Pesquisas Econômicas, encarregada de desenvolver uma pesquisa e apresentar seus resultados para o desenvolvimento da área central. Este foi também o período de elaboração de um Projeto Estratégico, capaz de endossar a contratação de um empréstimo para custear o programa. Para Cymbalista et al. (2008, p.22) este período inicial que compreendeu as gestões de Paulo Maluf (1993 - 1996) e Celso Pitta (1997 - 2000), ficou marcado pelo discurso público sobre a reabilitação do Centro focada na necessidade de recuperação de espaços públicos. A composição ideológica do discurso propalado fez referência aos aspectos amistosos dos investimentos privados, somados ao financiamento privado ${ }^{153}$, sempre enfatizando a entrada

\footnotetext{
153 A relação entre os investimentos privados e o financiamento privado encontrou como ponto mediador a PMSP e o mecanismo de desenvolvimento de uma proposta ao BID. Para o Polis (2008, p. 19-22) a Carta Consulta, elaborada para solicitar o empréstimo ao BID, previa a criação de um ambiente favorável aos investimentos privados e, ao mesmo tempo, mencionava um possível investimento posterior de forma que as linhas de crédito também fossem financiadas pelo setor privado, por meio da mediação da esfera pública. Segundo os autores, previa-se uma segunda etapa de financiamento do BID para o setor privado, de maneira que este desenvolvesse seus negócios de interesse na área central da metrópole. Já o segundo financiamento seria
} 
da iniciativa privada no processo de revalorização do Centro de São Paulo. O projeto estratégico resultou numa Carta que foi enviada ao BID - Banco Interamericano de Desenvolvimento; esta mesma carta, por algumas vezes e em mais de uma gestão, teve de ser reelaborada para que o projeto de financiamento fosse aprovado conforme os anseios da Prefeitura.

No ano de 2001, na gestão de Marta Suplicy, houve a revogação do decreto anterior (o primeiro de 1993 elaborado na gestão Paulo Maluf) e a aprovação de outro: o Decreto no 40.753, de 19 de Junho. Neste novo decreto algumas características apontaram o perfil desta gestão, como: regatar o caráter de espaço público da área central de modo coerente; ampliar o uso residencial e garantir a diversidade das funções; consolidar a identidade do Centro metropolitano; criar mecanismos de gestão democrática e interesse coletivo; e atuar na redução da violência. A comissão do programa também passava por significativa alteração de sua composição ${ }^{154}$,revelando o conflito entre os movimentos sociais e as entidades ligadas ao setor econômico do mercado imobiliário da cidade de São Paulo.

A relação que a Prefeitura Municipal manteve com o BID por meio do PROCENTRO caracterizou de certa forma uma relação de ajustes entre a gestão Marta Suplicy e o banco. A conjuntura da época já era marcada pelas ações dos movimentos sociais ligados à questão de moradia na metrópole, tanto na figura dos moradores das habitações em condição de cortiço

caracterizado por uma quantia maior de dinheiro e seria gerido pela Associação Viva Centro. A estratégia entre o setor privado e o setor público para a movimentação deste dinheiro emprestado, teve amparo nas medidas de intervenção que, territorialmente, visavam revalorizar o espaço do Centro de São Paulo de maneira combinada, onde uma estratégia de atração de investimentos privados (sob a justificativa da arrecadação) focasse nestes próprios investimentos as quantias emprestadas pelo BID, através do álibi da requalificação dos territórios. Meus grifos.

${ }^{154}$ Conforme o Artigo $4^{\text {o }}$ da Lei no 40.753 de Junho de 2001, a Coordenadoria de Programas de Reabilitação da Área Central - PROCENTRO será composta por: I - Secretaria de Implementação das Subprefeituras - SIS; II Secretaria da Habitação e Desenvolvimento Urbano - SEHAB; III - Secretaria Municipal de Planejamento Urbano - SEMPLA; IV - Secretaria Municipal de Cultura - SMC; V - Secretaria Municipal de Assistência Social - SAS; VI - Secretaria Municipal de Transportes - SMT; VII - Secretaria Municipal do Meio Ambiente - SMMA; VIII - Secretaria de Infra-Estrutura Urbana - SIURB; IX - Secretaria de Finanças e Desenvolvimento Econômico - SF; X - Secretaria dos Negócios Jurídicos - SJ; XI - Secretaria Municipal de Abastecimento - SEMAB; XII Secretaria Municipal de Esportes, Lazer e Recreação - SEME; XIII - Empresa Municipal de Urbanização EMURB; XIV - Companhia Metropolitana de Habitação de São Paulo - COHAB; XV - Companhia de Engenharia de Tráfego - CET; XVI - Anhembi - Turismo e Eventos da Cidade de São Paulo S/A; XVII Conselho de Defesa do Patrimônio Histórico, Arquitetônico, Arqueológico e Turístico do Estado de São Paulo CONDEPHAAT; XVIII - Caixa Econômica Federal - CEF; XIX - Associação Viva o Centro - AVC; XX Ordem dos Advogados do Brasil - OAB; XXI - Instituto de Arquitetos do Brasil - IAB; XXII - Instituto de Engenharia de São Paulo - IE; XXIII - Sindicato dos Arquitetos do Estado de São Paulo - SASP; XXIV Sindicato da Indústria da Construção Civil do Estado de São Paulo - SINDUSCON/SP; XXV - Sindicato das Empresas de Compra, Venda, Locação e Administração de Imóveis Residenciais e Comerciais de São Paulo SECOVI/SP; XXVI - Sindicato das Empresas de Propaganda Exterior do Estado de São Paulo - SEPEX/SP; XXVII - Associação Comercial de São Paulo; XXVIII - União dos Movimentos de Moradia - UMM; XXIX Centro Gaspar Garcia de Direitos Humanos; XXX - Fundação Projeto Travessia; XXXI - Associação União das Mulheres. 
quanto nos moradores dos prédios ocupados do Centro de São Paulo. Consequentemente, o governo de Marta ampliou as comissões com membros ligados a estes movimentos e, da mesma forma, ampliou os canais de abertura ligados às políticas habitacionais de interesse social no Centro de São Paulo, por meio do programa "Reconstruir o Centro" (2001 - 2002). Nos dois primeiros anos de governo o perímetro de aplicação do programa foi ampliado para 10 distritos, Sé e República e mais 08 distritos limítrofes, compreendendo os 10 distritos da então Administração Regional Sé (AR-SÉ), depois transformada em Subprefeitura Sé ${ }^{155}$.

As intervenções no espaço ocorriam sempre levando em conta as melhorias físicas e a valorização dos elementos históricos e culturais, tendo sempre a pauta da habitação social em primeiro plano. O caráter de ampliação popular nas ações voltadas ao Centro de São Paulo fez com que a gestão Marta tivesse alguns atritos com o BID, fazendo com que no ano de 2002 houvesse mudanças no rumo do programa, que passou a se chamar "Ação Centro" (2002 2004). Sob as determinações do BID as medidas de intervenção voltaram-se novamente para os distritos Sé e República, comprovando que amarrado ao banco, o governo da Prefeitura Municipal somente poderia conduzir a verba para as formas de investimento que verificam no espaço uma espécie de instrumento ativo. Isto significa que, ao produzir politicamente o espaço por meio destes investimentos, o Estado faz com que o espaço da cidade se metamorfoseie em força produtiva. Esta metamorfose está relacionada ao grau de desenvolvimento em que estas se encontram e, no atual período em que os traços da sociedade urbana são latentes e marcantes, a cidade e o urbano também entram como componentes que caracterizam a atualidade. As estruturas arquitetônico-urbanísticas, bem como as demais estruturas que implicam em formas para a cidade, formam o capital fixo que medem esta força produtiva. Contudo, no caso da metrópole, ela forma de abstração somente ocorre quando consideramos este aspecto em sua totalidade, especialmente quando averiguamos a totalidade da metrópole enquanto força produtiva em função da valorização diferenciada dos lugares. A revalorização do Centro, ainda mais quando considerada a partir das intervenções políticas postas em prática pelo Estado, torna-se um dos fundamentos deste processo de valorização que compõe uma unidade através da diversidade dos fragmentos da metrópole.

A aprovação do programa pelo BID fez com que o PROCENTRO somente fosse considerado em sua viabilidade a partir do momento em que as condicionalidades coadunavam com a estratégia política caracterizada pelo viés econômico, de maneira a enfatizar a relação entre regulação e desenvolvimento. De acordo com Viana (2008), as

155 Transformação fomentada por Lei em Agosto de 2002. 
exigências do Banco interferiram na autonomia do governo, pois, caracterizaram e desviaram os objetivos da política de intervenção no Centro, em função das condições impostas para o financiamento ${ }^{156}$. Ou seja, "é coerente que o Banco aprove um financiamento, apenas se o mesmo comprovar o retorno do investimento empenhado para sua realização" (VIANA, 2008, p.70). A aprovação do empréstimo por parte do banco ocorreu diante das garantias oferecidas pela PMSP, no tocante a aplicação da verba em obras de intervenção que de fato trouxessem um retorno e fomentassem o estímulo à reprodução do capital por meio da reprodução do Centro de São Paulo. As exigências do Banco financiador das intervenções tinham como contrapartida a aplicação de modelos de revalorização de centros urbanos que já ocorriam em outras metrópoles e cidades do mundo. Neste movimento, a reprodução do espaço revela também sua mundialidade no tocante à homogeneização das formas de sua produção. A reprodução do Centro de São Paulo se realizou enquanto uma tendência de um processo que já ocorrera em escala global e evidenciava naquele momento uma forma em que o espaço realizava sua mundialidade na escala do lugar. Por meio de condições específicas, os US\$ 100,4 milhões financiados tiveram o prazo de 25 anos para serem quitados.

A verba do empréstimo foi direcionada integralmente para o governo José Serra e Gilberto Kassab (2005 - 2008) e, até o ano de 2008, estes governos tinham utilizado apenas $4 \%$ da verba disponibilizada pelo Banco ${ }^{157}$. Neste período de governo houve inversões significativas das medidas tomadas por Marta, revertendo um processo em que havia maior participação popular e que imprimia ao PROCENTRO as características que eram mais afeitas ao BID. Neste período novas estratégias também foram postas em pauta, como: 1) a elaboração do Projeto "Nova Luz"; 2) o aumento das ações policiais de repressão aos moradores em situação de rua, comerciantes informais e catadores de materiais recicláveis; e 3) a necessidade de revitalização da chamada cracolândia (com vistas à iniciativa privada) $)^{158}$. Até Maio de 2007, tinha-se ainda para investir no PROCENTRO o saldo de $63 \%$ do montante correspondente ao BID (US\$ 89.284.468,00), 37\% do montante correspondente ao aporte local PMSP (US\$ 51.783.097,03), totalizando US\$ $141.067 .565,03^{159}$. A revalorização do Centro de São Paulo, através dos governos ligados a uma abertura maior às políticas de cunho neoliberal, ficou mais caracterizada pelo controle do Estado no espaço público e da renovação

\footnotetext{
${ }^{156}$ A aprovação do financiamento do PROCENTRO junto ao BID e junto a CAE (Comissão de Assuntos Econômicos do Senado, entidade responsável para liberar empréstimos internacionais) somente ocorreu no último semestre do governo Marta, em Junho de 2004, com o auxílio do então senador Aloísio Mercadante, presidente da comissão.

157 Viana, 2008, p.51.

${ }^{158}$ Cymbalista et al, 2008, p.67.

159 Ibidem, p.72.
} 
e proposição de novas estratégias políticas para o processo de produção de uma nova representação ao Centro de São Paulo.

Na gestão Serra/Kassab (2005-2008) e, posteriormente, na gestão reeleita de Gilberto Kassab (2009-2012), ocorreu que, dos cinco componentes estruturadores do programa ${ }^{160}$, apenas o primeiro teve maior atenção. Ao concentrar as ações em torno do primeiro eixo estruturante, o resultado foi o aumento do Imposto Territorial Predial Urbano (IPTU). Segundo Neves (2012) a valorização do $\mathrm{m}^{2}$ na área central implicou no aumento de aproximadamente $60 \%$ do valor de aluguel de terrenos públicos, rebatendo no acréscimo do aluguel de residências privadas.

Desde seu surgimento o PROCENTRO carrega a missão de ser uma política espacial de cunho revalorizador de um território delimitado a partir do Centro Histórico e que compreende, também, a área central. A relação de separação e independência do PROCENTRO com as demais estratégias para a revalorização do Centro, ocorreu em função de alguns motivos. Primeiramente pelo empréstimo concedido pelo BID onde o uso da verba se deu, de fato, apenas na segunda gestão do prefeito Gilberto Kassab (2009 - 2012). O segundo fator consiste na relativa autonomia da prefeitura para direcionar os gastos e priorizar alguns eixos estruturantes da política. Nesse caso em específico, as medidas prioritárias foram àquelas voltadas à reversão da desvalorização imobiliária somadas às medidas de intervenção que também integravam a recuperação do ambiente urbano, no terceiro eixo.

No que tange ao aspecto dos eixos estruturantes, os dados emitidos pela SPUrbanismo em referência ao PROCENTRO são expostos de maneira que possam ser confundidos os conteúdos desta política de intervenção no espaço. Alguns nomes são "trocados" como, por exemplo, o do Eixo 1, caracterizado pela Reversão da Desvalorização Imobiliária, que consiste em algumas medidas de intervenção urbanística e na produção de unidades habitacionais na área central (o Parque do Gato no Bom Retiro; e o Conjunto Olarias e Canindé, localizado no distrito do Pari). A tabela 04 expõe os eixos de intervenção que foram destinados a verba do BID.

\footnotetext{
${ }^{160}$ São os cinco componentes que estruturam (ou estruturaram) o programa PROCENTRO: 1) a reversão da desvalorização imobiliária e recuperação da função residencial, através da: elaboração de proposta de legislação urbanística e tributária, intervenções urbanísticas e morar no Centro; 2) transformação do perfil econômico e social, através da: criação de mecanismo de articulação com o setor privado, divulgação do programa, regularização do comércio informal, segurança pública e atenção aos grupos vulneráveis; 3) recuperação do ambiente urbano, por meio da: gestão de operação e manutenção, requalificação do espaço público, requalificação de edifícios, controle de inundações, resíduos sólidos recicláveis; 4) transporte e circulação: fortalecimento institucional da secretaria municipal de transportes, circulação e acessibilidade, operação de transito, transporte público; 5) fortalecimento institucional do município: no fortalecimento do sistema de planificação urbana, na transferência de órgãos municipais para o Centro, na formação de gerentes sociais e na valorização do patrimônio histórico.
} 
Tabela 4 - BID: recursos empregados no PROCENTRO

\begin{tabular}{c|l|l|c}
\hline \multicolumn{2}{|c|}{ Eixos } & Recurso empregado & \% do Recurso \\
\hline 1 & $\begin{array}{l}\text { Reversão da des valorização imobiliária e } \\
\text { recuperação da função residencial }\end{array}$ & $\mathrm{R} \$ 10.632 .627,54$ & 7,31 \\
\hline 2 & Trans formação do perfil econômico e social & $\mathrm{R} \$ 3.196 .109,45$ & 2,20 \\
\hline 3 & Recuperação do ambiente urbano & $\mathrm{R} \$ 101.045 .689,90$ & 69,47 \\
\hline 4 & Transporte e circulação & $\mathrm{R} \$ 15.290 .181,64$ & 10,51 \\
\hline 5 & Fortalecimento institucional do município & $\mathrm{R} \$ 3.474 .416,07$ & 2,39 \\
\hline & Administração e supervisão & $\mathrm{R} \$ 11.816 .954,70$ & 8,12 \\
\hline & Total & $\mathbf{R} \$ \mathbf{1 4 5 . 4 5 5 . 9 7 9 , 3 0}$ & $\mathbf{1 0 0 , 0 0}$ \\
\hline
\end{tabular}

Fonte: SP Urbanismo - PROCENTRO

Elaboração e adaptação

Gilmar Soares, Setembro, 2013.

$\mathrm{Na}$ interpretação dos dados é plausível compreender que a reversão da desvalorização imobiliária deve ser compreendida no Eixo 3, de Recuperação do Ambiente Urbano. Se o BID emprestou a PMSP o total de US\$ 100.314.176,27, somente no componente de recuperação de ambiente urbano foram gastos $69,47 \%$ (valores em reais), sendo que o restante complementar correspondeu aos valores acrescidos pela prefeitura. Aliás, somados ao total disponibilizado pelo BID, tem-se a quantia de US\$ 88.990.056,24 disponibilizados pela Prefeitura Municipal de São Paulo, caracterizando o montante de US\$ 189.304.232,51. Tendo em mente que o item 3 foi o responsável pelas obras inerentes à revalorização do centro e da área central em relação ao total de verba do PROCENTRO, somente este item correspondeu a $53,38 \%$ do total, ultrapassando mais da metade do valor que somou as verbas do BID e da PMSP. O quadro de resumo dos contratos nos dá uma dimensão exata como foram alocados os fragmentos do investimento. Reformas de praças, recuperação de jardins, obras de reurbanização de praças (República, Sé, Roosevelt), obras de requalificação urbana da rua do Gasômetro e seu entorno, obras de reforma da Biblioteca Mario de Andrade, obras de requalificação de edifícios (Mercado Municipal, Teatro Municipal como os mais significativos). No que tange aos aspectos relacionados à moradia no Centro, vale ressaltar que nenhum projeto compreendeu medidas que incentivassem a localização de moradias populares no Centro Histórico ou em áreas mais próximas ao distrito Sé e República. No que tange às medidas de moradia popular, apenas 7,04\% do total do valor empregado em todo PROCENTRO foram direcionados a esse eixo de estruturação (tabela05). 
Tabela 5 - Intervenções Urbanísticas do PROCENTRO

\begin{tabular}{|c|c|c|c|c|c|}
\hline \multicolumn{6}{|c|}{ Intervenções urbanísticas } \\
\hline Ação & $\begin{array}{c:c}\text { Ano } & \\
\text { Conclusão } & \end{array}$ & \multicolumn{2}{|c|}{$\begin{array}{l}\text { Valor do Contrato } \\
\text { em Reais }\end{array}$} & \multicolumn{2}{|c|}{$\begin{array}{c}\text { Valor do } \\
\text { Contrato em } \\
\text { Dolares } \\
\end{array}$} \\
\hline $\begin{array}{l}\text { Estudos estratégicos para desenvolvimento } \\
\text { econômico }\end{array}$ & 2003 & $\mathrm{R} \$$ & $342.256,00$ & $\$$ & $113.956,98$ \\
\hline $\begin{array}{l}\text { Recuperação urbana e ambiental da região do } \\
\text { parque do gato }\end{array}$ & 2004 & $\mathrm{R} \$$ & $4.985 .515,75$ & $\$$ & $1.668 .423,71$ \\
\hline Estudos urbanísticos sobre o vetor leste & 2007 & $\mathrm{R} \$$ & $468.398,00$ & $\$$ & $213.909,67$ \\
\hline $\begin{array}{l}\text { Levantamento e desenvolvimento de plantas de } \\
\text { valores imobiliários }\end{array}$ & 2007 & $\mathrm{R} \$$ & $61.947,84$ & $\$$ & $28.663,63$ \\
\hline $\begin{array}{l}\text { Estudo vocacional da Nova Luz e Plano de } \\
\text { negócios }\end{array}$ & 2007 & $\mathrm{R} \$$ & $51.921,60$ & $\$$ & $24.024,43$ \\
\hline & & $\mathrm{R} \$$ & $5.910 .039,19$ & $\$$ & $2.048 .978,42$ \\
\hline \multicolumn{6}{|c|}{ Morar no Centro } \\
\hline $\begin{array}{l}\text { Provisão e reformas de edifícios - Obras (Conjunto } \\
\text { Habitacional Gato e Olarias) }\end{array}$ & 2004 & $\mathrm{R} \$$ & $20.998 .849,44$ & $\$$ & 7.111.026,58 \\
\hline $\begin{array}{l}\text { Projetos de implementação de melhoria ambiental } \\
\text { dos perímetros de reabilitação integrada do } \\
\text { Habitat (PRIH), nas ruas São Lázaro e Posidônio }\end{array}$ & 2009 & $\mathrm{R} \$$ & $23.500,00$ & $\$$ & $10.833,49$ \\
\hline $\begin{array}{l}\text { Obras de construção do centro comercial parque } \\
\text { do Gato }\end{array}$ & 2013 & $\mathrm{R} \$$ & $1.214 .814,77$ & $\$$ & $727.129,21$ \\
\hline $\begin{array}{l}\text { Obras de reforma/manutenção dos conjuntos } \\
\text { residenciais Parque do Gato e Olarias }\end{array}$ & 2011 & $\mathrm{R} \$$ & $1.223 .502,50$ & $\$$ & $734.659,84$ \\
\hline & & $\mathrm{R} \$$ & $23.460 .666,71$ & $\$$ & $8.583 .649,12$ \\
\hline Total de gastos com Parque do Gato & & $\mathbf{R} \$$ & $8.422 .682,46$ & & $0.241 .239,34$ \\
\hline Total de gastos com Componente I & & & & & $0.632 .627,54$ \\
\hline
\end{tabular}

Fonte: SP Urbanismo - PROCENTRO

Organização: Gilmar Soares, 2014.

As obras de moradia popular que datam do ano de 2004 corresponderam apenas 5,41\% do total do montante investido no PROCENTRO. Outro fator que devemos destacar é a quantia de mais de 50 mil reais investida na elaboração do Projeto "Nova Luz": fato que corrobora com o percurso de análise das especificidades de revalorização do Centro. A compreensão do movimento de revalorização constitui-se no exercício de compreender como ocorreram no tempo e no espaço a articulação das políticas de intervenção na área centra. A articulação das políticas possibilita-nos visualizar as estratégias que se realizam com o objetivo de reproduzir os conteúdos do Centro de São Paulo e seu entorno, por da produção de novas representações do espaço. 
Figura 7 - Espacialização das Intervenções Urbanísticas do PROCENTRO/BID
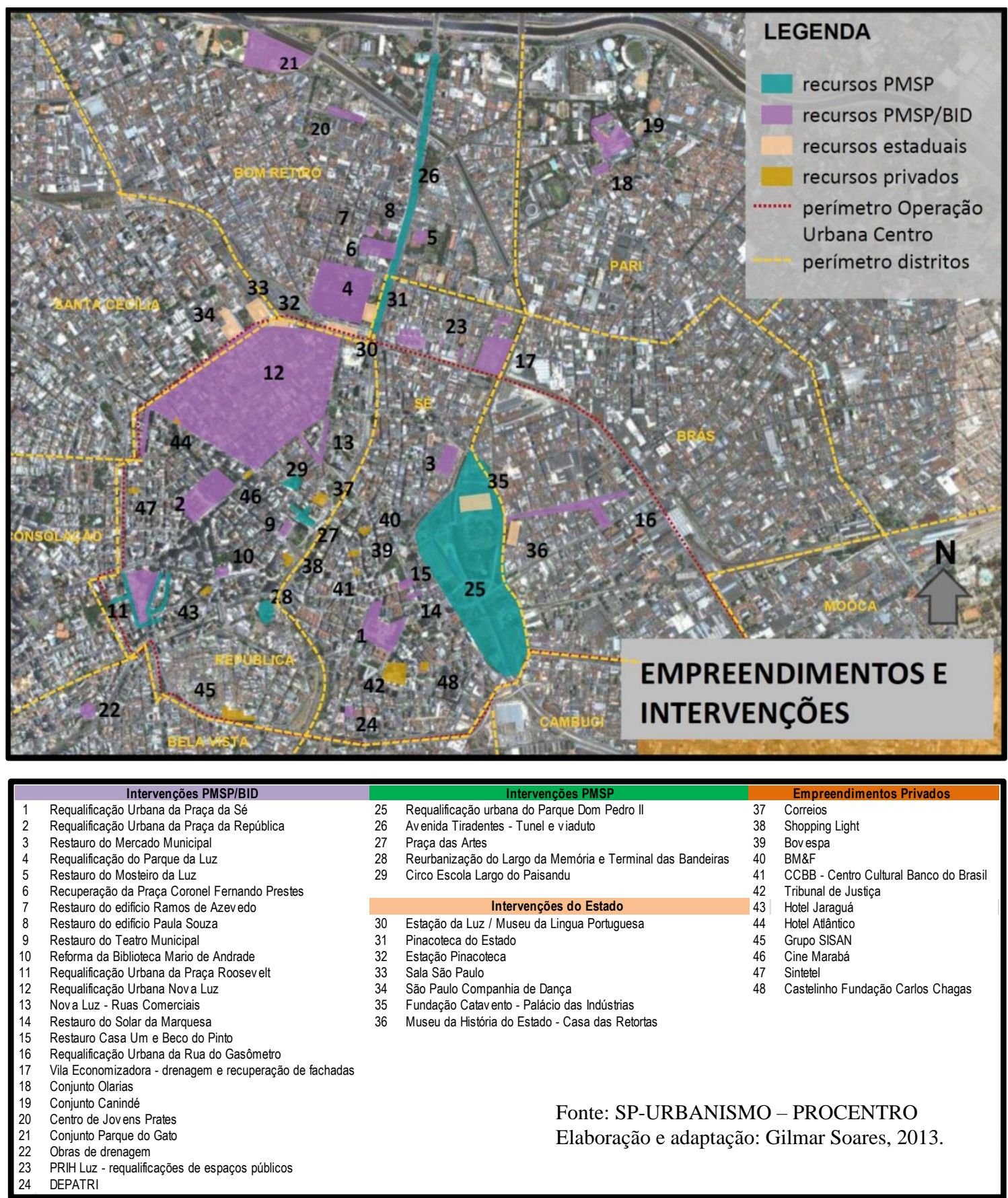

Fonte: SP-URBANISMO - PROCENTRO

Elaboração e adaptação: Gilmar Soares, 2013.

A mudança no rumo das políticas para o Centro de São Paulo neste período do governo Marta, revela como que a forma política do Estado é intrinsecamente ligada ao modo de socialização contraditório, ou seja, é aquilo que é constituído e ao mesmo tempo constitui a reprodução ${ }^{161}$, tanto da morfologia social quanto da morfologia espacial, no capitalismo.

A mundialidade do espaço atribui para o Centro de São Paulo o direcionamento das estratégias de sua revalorização por meio de uma ordem distante que somente ganha

${ }^{161}$ Hirsh (2010), Mascaro (2013), Osório (2014), Althusser (2008). 
materialidade ao se realizar na escala do lugar. Contudo, é no lugar, portanto, na vida cotidiana, que os limites para a reprodução do espaço se realizam e, assim, contribuem com o andamento e o tempo de execução dessas políticas de intervenção no Centro de São Paulo. Diferente do caso Puerto Madero (política usada de parâmetro para o segundo momento do PROCENTRO no governo Marta Suplicy), diferente do caso modelo das políticas de revalorização postas em prática em Barcelona na Espanha, o processo de revalorização do Centro de São Paulo carrega consigo uma contradição que é histórica, derivada da problemática que se originou em seu processo de industrialização.

A particularidade da metrópole paulistana na perspectiva de uma realidade urbana em formação, deriva do processo anterior que a fez implodir. Assim, a industrialização, por meio da efetivação do capitalismo como modo de produção, se tornou o processo responsável pela produção dos excessos, cujos conflitos foram todos direcionados e conduzidos através da racionalidade do Estado. A relação destes excessos (incluindo as configurações da sociedade cindida em classes sociais) com a explosão da metrópole - e posteriormente com as transformações no predomínio da dimensão econômico-produtiva - apresentou uma particularidade inerente à problemática urbana no Centro. Ao se desvalorizar em função do desdobramento da sua centralidade econômica, houve uma desvalorização do Centro de São Paulo enquanto um lugar a ser habitado. Com a saída das elites houve a intensificação da ocupação proletária deste fragmento da metrópole.

Este é o movimento histórico que fundamenta o surgimento dessas políticas urbanoterritoriais para o Centro de São Paulo. Ao serem elaboradas, estas políticas (sob a influência do BID como agência internacional de fomento) direcionam os recursos para fomentar as condições de reprodução de fragmentos da cidade capazes de promover o desencadeamento de um processo de acumulação de capital. Assim, mais do que um city-marketing ${ }^{162}$, em que as políticas fossem uma espécie de prática do Estado capaz de promover a cidade, o que passou a existir, por meio das formas de governança e da lógica administrativa de condução do Estado, foi uma transformação significativa das condições e meios, como uma espécie de ajustes, que fazem com que a cidade se torne um negócio cada vez mais lucrativo.

A cidade e o urbano são produções históricas que o capitalismo e sua matriz de reprodução se apropriaram para dar continuidade tanto ao ciclo de acumulação quanto à continuidade da sociedade de classes; ambas, atravessadas e caracterizadas por diversas formas de conflitos que derivam das contradições históricas e atuais. Coube ao Estado 
dominar, controlar e direcionar essas relações conflituais que explodem na cidade e na vida urbana. Neste sentido, as políticas surgem também para desenvolver formas de acumulação desta realidade conduzida pelo Estado e, assim, seus diversos momentos e variações revelam, por meio da ação institucional, os ajustes necessários à reprodução da cidade e da vida urbana. O PROCENTRO, de certa forma, marca esta transição das políticas de intervenção no espaço que eram pontuais (predominante em décadas anteriores) para as políticas de cunho estratégico, que se realizam por meio da delimitação de territórios específicos em que a ação do Estado produz todas as condições para que o espaço se transforme em mercadoria, neste caso, produzindo uma série de infraestruturas e adequações políticas para que sua produção resulte num consumo específico.

\subsubsection{Concessão Urbanística - Projeto "Nova Luz"}

No mês de Junho de 2013 deferiu-se que a Fazenda Pública do Município de São Paulo - PMSP "se abstenha de promover por si só ou por meio de terceiros, qualquer intervenção urbanística na área objeto do Projeto Nova Luz, fundada na aprovação do Plano de Urbanização objeto de questionamento" (TJSP, Processo no 0019326-64.2012.8.26.0053 Ação Civil Pública, p.4-5). Emitida pela MM.(a) Juiz(a) de Direito Dr(a). Alexandra Fuchs de Araújo, e promovida pela Defensoria Pública do Estado de São Paulo, esta liminar de deferimento somente foi emitida por falta de participação popular. Sob este argumento, que se estabeleceu nos termos que são próprios ao Estatuto da Cidade $^{163}$ como também à Constituição, houve a aprovação da liminar que proibiu qualquer medida de intervenção ou ação da PMSP no território que compreende o perímetro do Projeto "Nova Luz" (Mapa 02) e, até mesmo, a publicação de outro edital ou algum chamamento público. Desde a elaboração do plano de Lei, passando pela aprovação da própria lei até a emissão do edital, os procedimentos e mecanismos jurídicos resultaram na "formação tardia do Conselho Gestor, verdadeiro 'paredão' formado quanto às propostas populares ${ }^{164 \%}$. Tal prática compreendeu um indício que serviu de argumento para o próprio embargo do projeto.

\footnotetext{
${ }^{163}$ Sempre destacando a gestão democrática da cidade no Estatuto, o argumento de atribuição da decisão baseouse no artigo 182 da Constituição Federal onde, enfaticamente, destacou a necessidade de participação social e efetiva para fins adequados de execução do processo de desenvolvimento urbano., por meio de canais de comunicação entre os habitantes da cidade e suas respectivas manifestações. Ainda no fundamento do argumento, a Juíza, apoiada nas considerações do Ministério Público em seu parecer, salientou que "a situação atual é de constante desrespeito da Prefeitura Municipal para com a exigência constitucional e infraconstitucional da necessidade de participação popular nos processos deliberativos relativos às políticas públicas de habitação" (p. 3).

${ }^{164}$ TJSP, Processo nº 0019326-64.2012.8.26.0053 - Ação Civil Pública, p.4.
} 
Mapa 2- Território da Concessão Urbanística Projeto "Nova Luz"

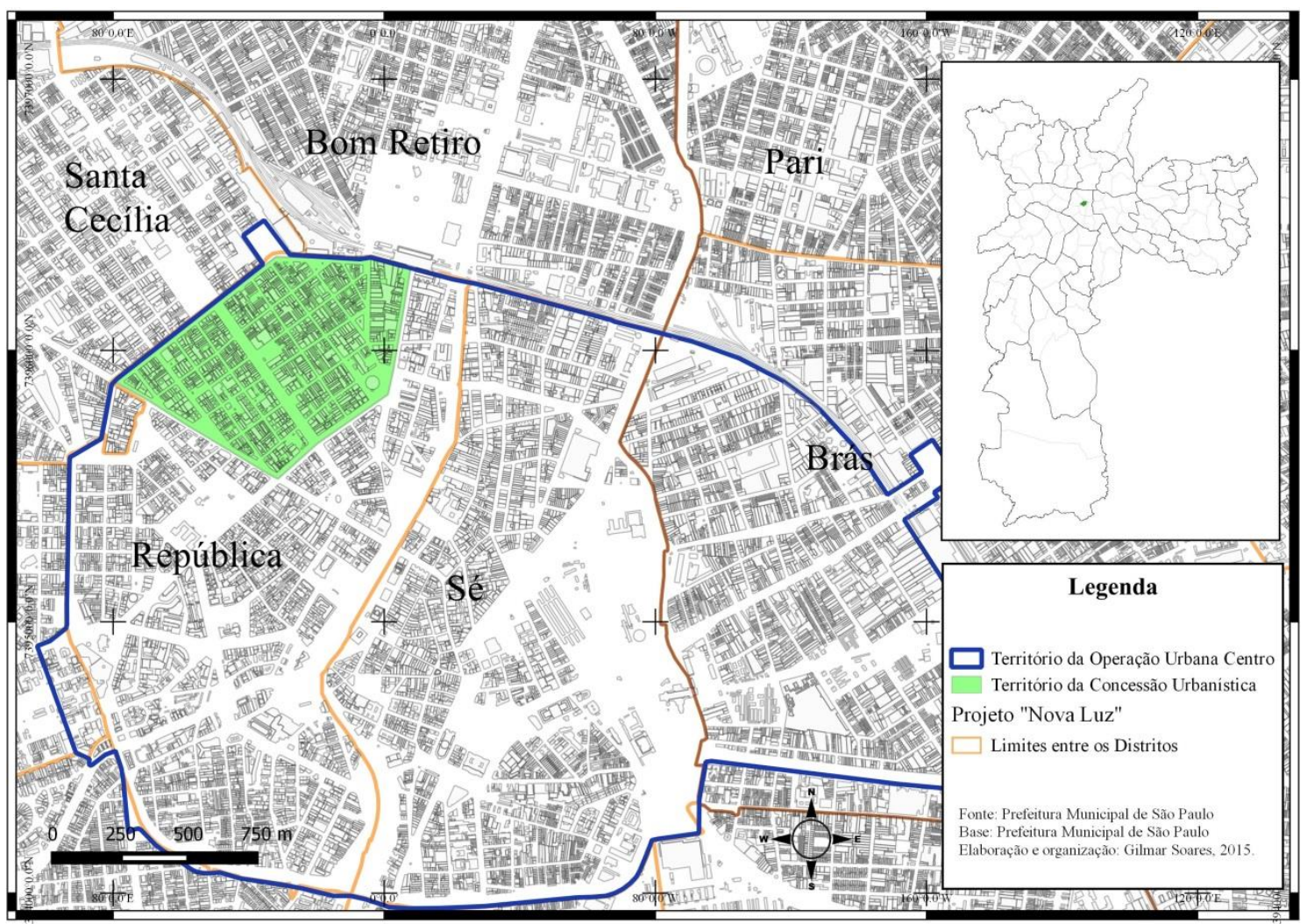

Cerca de cinco meses antes da emissão desta liminar, o Prefeito Fernando Haddad, no primeiro mês de sua gestão, já considerava do ponto de vista econômico financeiro tecnicamente inviável a concessão urbanística "Nova Luz", pelo fato desta já ter "consumido" o montante de 14 milhões de reais ${ }^{165}$. Ainda de acordo com a notícia, a conversa da prefeitura com os representantes do consórcio ganhador do processo licitatório encaminhou-se com a recomendação do próprio grupo para que a instituição pública analisasse o projeto na forma de PPP (parceria público-privada). Levando em conta o Centro de São Paulo, com uma parcela significativa de proletários em sua ocupação, coube a Prefeitura Municipal de São Paulo elaborar sua primeira tentativa de privatização de um fragmento da metrópole pela via e/ou mecanismo jurídico da concessão urbanística.

Várias pesquisas ${ }^{166}$ sobre a concessão urbanística Projeto "Nova Luz" foram realizadas e evidenciaram considerações significativas do conteúdo desta política, contudo, esta exposição consiste no esforço de expor como que este mecanismo de intervenção para a produção política da metrópole revela a tendência de consolidação desta nova faceta

\footnotetext{
${ }^{165}$ Notícia veiculada pelo jornal Metrô News - SP, em 29 de Janeiro de 2013 em sua seção Geral. Acessada por mim nos arquivos do site da Prefeitura Municipal de São Paulo em Fevereiro de 2014.

${ }^{166}$ Pezoti (2012), Couto (2011), Souza (2010), Vaz (2009) entre outros. Além da diversidade de artigos, Ações
} Civis Publica e notícias vinculados na imprensa estão relacionadas ao Projeto "Nova Luz. 
estratégica em que há a privatização do espaço. Ao conceder parcelas significativas do espaço para a iniciativa privada, mais do que oferecer as condições para que se produza o espaço à condição de forma-mercadoria, o que passa a existir são formas de produção, regulamentação, controle e/ou direcionamento do espaço. Se o PROCENTRO foi o responsável por algumas características importantes para a consolidação das políticas urbano-territoriais, a forma concessão urbanística foi uma primeira tentativa de reprodução do espaço por meio de seu processo de privatização.

A concessão urbanística ${ }^{167}$ consiste em um instrumento de intervenção urbana, realizado por meio de contrato administrativo em que o Estado concede à pessoa jurídica ou ao consórcio de empresas a execução de obras urbanísticas de interesse público. Portanto, uma concessão para a exploração econômica de praticamente tudo que compõe e se localiza no território concedido. No regime de concessão urbanística, além do controle da produção de unidades privadas do espaço (unidades habitacionais, comerciais, de produção etc.), a pessoa jurídica ou o consórcio de empresas também fica incumbido de realizar as obras de reprodução deste fragmento da cidade, controlando integralmente o processo de urbanização. Ao ter o controle pleno e o domínio sobre o território do Projeto "Nova Luz", a empresa ficaria encarregada das transformações no loteamento (por remembramento de lotes), na demolição de edifícios e reconstituição, na reforma total de imóveis ou mesmo na incorporação de conjuntos de edificações.

No caso do Projeto "Nova Luz", o território liberado para as intervenções naquele momento foi concedido ao Consórcio que era compostos pelas empresas AECON, Cia City, FGV e Concremat. Mesmo levando em conta todas essas dimensões que compõe o texto das normas que legitimam a concessão urbanística enquanto um instrumento de intervenção no espaço urbano, vale salientar que uma importante consideração acerca do tempo de concessão acaba não sendo exposto, de maneira que este quesito acaba ficando a cargo das relações diretas entre o Estado e a empresa concessionária. Talvez considerado como o fator de maior importância, o tempo de permanência da concessão tornaria-se uma chave de primeira ordem para se pensar no andamento das intervenções e da estratégia de intervenção.

A aprovação da lei de concessão urbanística se deu no momento em que o PROCENTRO se aproximava de seu prazo de encerramento e a Operação Urbana Centro ainda buscava (e busca) um curso mais adequado - do ponto de vista da aceleração das intervenções - para sua realização no Centro de São Paulo. A estratégia do Estado, nesse caso

${ }^{167}$ Lei no 14.917 , de maio de 2009, artigo $2^{\circ}$. 
em que outras intervenções ocorriam em condições específicas, consistiu em transferir integralmente ao setor privado o bairro de Santa Ifigênia, portador de uma das "qualidades" que mais desvaloriza o Centro (por inteiro, de Centro Histórico à Área Central): a cracolândia.

A paisagem deteriorada dos edifícios como também do espaço público, pela primeira vez também constitui (e ainda se constitui) uma parte do negocio, pois, quanto mais miserável, quanto mais crasso, quanto mais desumando, mais desvalorizado torna-se o espaço. Assim, mais favorável este torna-se para os investidores privados interessados em comprar a preços baixos a propriedade privada do solo urbano. Se na figura do Estado encontram-se as condições que tornam violento o processo de urbanização $^{168}$, a apropriação do resultado histórico (na figura da miséria e das condições/situações crassas em que se encontram os sujeitos usuários de crack) que deriva da sociedade de classes, e servem para fomentar formas de ampliação da acumulação por consistirem em um dos elementos da desvalorização, caracteriza o momento de barbárie ${ }^{169}$ do atual processo de reprodução da metrópole. Assim, a concessão urbanística Projeto "Nova Luz", enquanto uma estratégia política para a revalorização do Centro de São Paulo, seria também uma modalidade de planejamento que assumiria a condição da produção de novas modalidades de apropriação do lugar, produzindo também a identidade do lugar.

A delimitação estratégica de territórios que possam ser objeto de concessão urbanística consiste numa forma de atribuir a iniciativa privada as possibilidades de auferir rendas com o próprio processo de urbanização. A partir do momento em que a empresa capitalista não fica mais encarregada apenas da produção de unidades privada do espaço (independente de serem unidades habitacionais ou comerciais), os procedimentos de gestão, regulamentação, controle e direcionamento do espaço constitui-se numa forma atual em que passa a ocorrer, literalmente, a privatização do processo de urbanização.

Evidente que o Projeto "Nova Luz" apenas consistiu num plano que acabou sendo embargado, contudo, seu modelo serve para fundamentar, por exemplo, as intervenções

\footnotetext{
${ }^{168}$ Conforme assevera (SAMPAIO, 2015, p.61), o processo de urbanização se institucionaliza politicamente e atua, por sua vez, como uma das mediações para o exercício do poder do Estado, que vem acompanhado do uso de seus correspondentes, como a coerção, a dominação, a repressão, a ordenação, cuja consequência lógica - o plano dos danos - pode caracterizar, em parte, o conteúdo de violência do próprio processo de urbanização [...] mais especificamente sua face estatal: o planejamento urbano.

${ }^{169}$ Para (MENEGAT, 2012, p. 151-152) a barbárie - que não pode ser entendida como um fato, uma ocorrência, ou a consequência de uma crise cíclica, mas um modo geral de organização a partir dos escombros que resultam desta crise estrutural, ou seja, não apenas como uma objetivação inconsciente, mas também como uma subjetividade fria, dessolidarizada e cruel, perfeitamente adequada à naturalização da monstruosidade a que o mundo vai sendo reduzido - será a forma dominante das relações sociais, ao mesmo enquanto o capitalismo agonizar sem ser substituído por uma forma social superior.
} 
urbanísticas que tendem a ocorrer ao longo do "Arco do Futuro". Das quatro âncoras ${ }^{170}$ que seriam criadas e estão no projeto, duas comporiam os setores residenciais, outra seria o Centro de Cultura e Entretenimento (Quadra 19) e outra o Polo de Comercio e Serviços ${ }^{171}$. Tais âncoras, neste caso, não seriam planejadas apenas para comporem uma dimensão de relação entre os conteúdos que preencheriam o território do Projeto "Nova Luz". Neste caso, as âncoras que seriam produzidas no projeto também complementariam (e seriam complementadas) pelos equipamentos culturais existentes neste fragmento da cidade: a Sala São Paulo, o Parque da Luz, a Praça da República, o Largo do Arouche, a Praça Princesa Isabel e o Largo do Paissandu. A disposição destas âncoras no direcionamento dos espaços, se relacionariam também com a hierarquização dos "espaços livres" (afinal, em pelo fato do projeto evidenciar uma privatização do espaço urbano, este, pela lógica, não poderia ser mais considerado como público).

Figura 8 - Âncoras e Conexões do Projeto "Nova Luz"

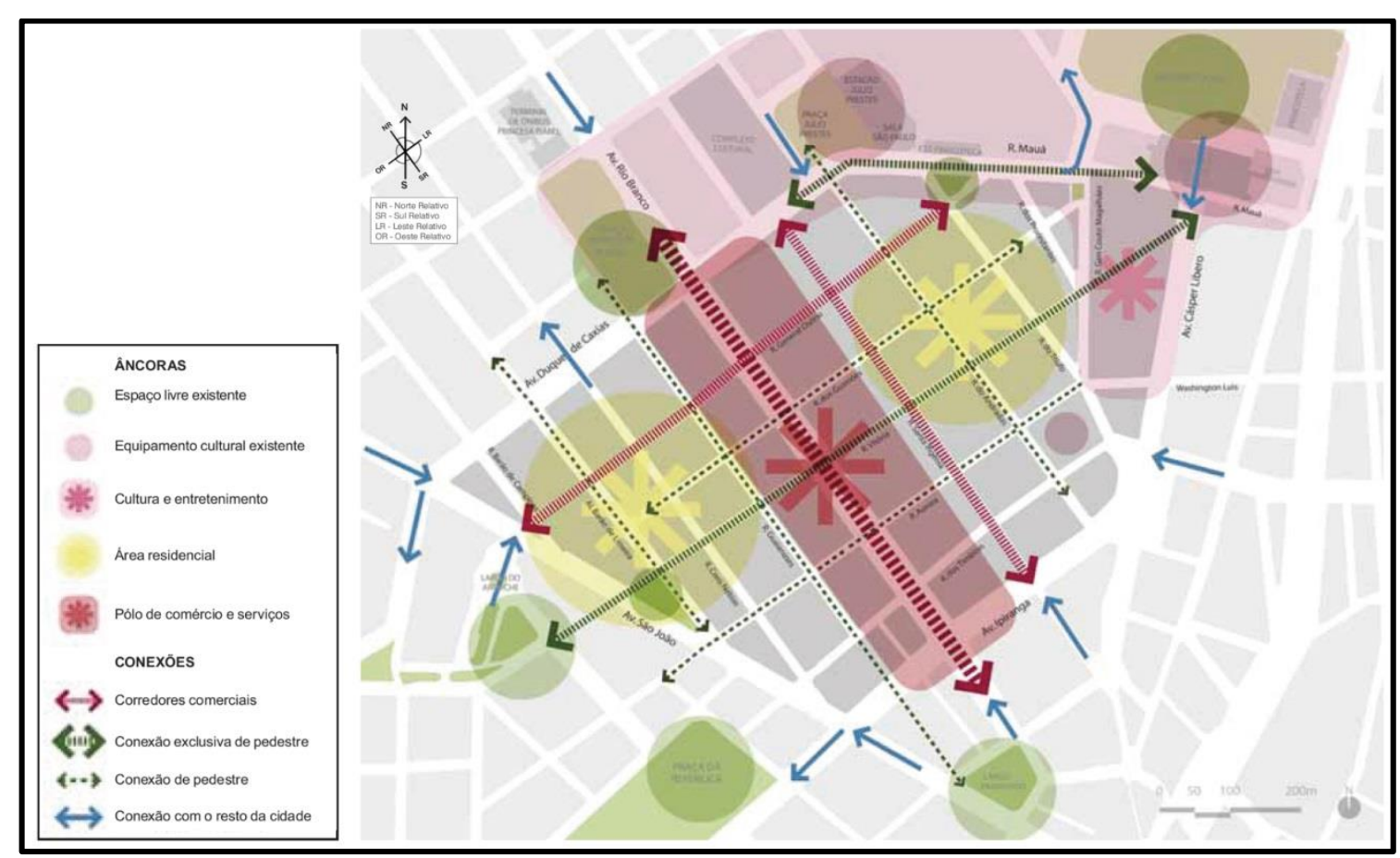

Fonte: Projeto Nova Luz. São Paulo, SP, Brasil.

Projeto Urbanístico Específico (PUE).

Julho de 2011.

\footnotetext{
${ }^{170}$ A duas primeiras compreendriam dois setores residenciais. A terceira âncora seria composta por um Centro de cultura e entretenimento e a quarta por um polo de comércio e serviços. Segundo o PUE Nova Luz, as âncoras criadas complementariam as existentes, tais como a Sala São Paulo, o Parque da Luz, a Praça da República e Largo do Arouche, a Praça Princesa Isabel e o Largo Paissandú.

${ }^{171}$ Ibidem.
} 
A composição das relações do espaço evidenciaria, na concessão urbanística Projeto "Nova Luz", uma forma de esquema onde a dimensão abstrata do espaço também se realizaria enquanto uma dimensão concreta-direcionada, afinal, a relação entre o espaço privado com os "espaços livres" (espaço privatizado), e os espaços públicos do bairro, comporiam uma dinâmica espacial em que os conteúdos produzidos do lugar tenderiam a revelar uma identidade desvinculada da memória de quem o apropria. Provavelmente, o território da concessão urbanística, ao articular estas três esferas de espaço (público, privado e privatizado), fosse capaz de promover em seus usadores o senso de identidade que mais se assimilasse a um Shopping Center.

A compreensão do uso do solo no perímetro do projeto "Nova Luz" apenas nos remete ao fato de que, independente das formas de $u^{172}$ (mistos ou não, com âncoras ou não), é o advento da propriedade privada do solo urbano que servirá de parâmetro para a constituição e reprodução destes espaços, seja por meio de remembramentos ou fracionamentos da unidade. A hierarquia dos espaços, elaboradas a partir das formas de uso caracterizada pelas âncoras, deveriam se constituir no próprio fundamento para a comercialização espaço em sua nova forma. O fato é que os princípios do uso do solo seriam elaborados a partir dos setores de serviços (localizados nos bulevares periféricos e na Avenida Rio Branco, sempre caracterizados pelo uso de escritórios), do setor comercial (na Rua General Osório e Rua Santa Ifigênia, Rua Vitória e Setor Mauá), no que tinha sido posto como eixo de entretenimento e cultura (localizado no que era considerado o setor Mauá), e, por fim, no uso residencial (nos setores Triunfo e Nébias).

O Projeto "Nova Luz" comportava todos os elementos constitutivos da lógica que se configura atualmente para o espaço urbano da metrópole, ou seja, aquela constituída e constitutiva nas referências da forma-mercadoria, pois, todas as referências da atividade técnica do grupo elaborador do projeto eram atravessadas pelas relações de compra, consumo e valorização do/nos espaços. Essas mesmas relações, que também eram categorias constituidoras do projeto, denotavam a especificidade do espaço vinculada à formamercadoria e sua possibilidade de reprodução.

O espaço produzido historicamente torna-se portador de conteúdos que permitem com que o mesmo se metamorfoseie em matéria-prima para reproduzir a cidade e a vida urbana.

\footnotetext{
172 Conforme o projeto urbanístico que foi feito, os usos foram definidos em setores de uso misto e com âncoras urbanas que nada mais é do que um sistema de hierarquia entre os espaços públicos. Em função das suas especificidades, criam diferentes tipologias urbanísticas (que mais se assemelham às topologias da professora Sandra Lencioni), pois, fazem com que haja entre estes espaços a variação do preço em função daquilo que os constitui.
} 
No território estrategicamente delimitado para a concessão urbanística Projeto "Nova Luz", as potencialidades que caracterizavam o território, para além daquelas inscritas e delimitadas no perímetro, estavam também naquelas que estão no entorno do território: bairros adjacentes e seus equipamentos urbanos, sistemas de transportes (redes, fluxos, vias etc.), no próprio distrito, na localização contígua ao Centro Histórico da cidade de São Paulo entre outras.

A delimitação deste território estratégico, primeiramente, condiz com o fato de que, por meio de suas qualidades historicamente produzidas e acumuladas (levando em conta sua relação com o entorno), o espaço torna-se também a matéria-prima para a realização da sua própria reprodução ${ }^{173}$. Resultado histórico do acumulo de trabalho morto acumulado, a revalorização do espaço se realiza a partir do momento em que, por meio de determinações e conteúdos específicos, o trabalho vivo se apropria do trabalho morto e todas suas condições, fazendo com que este funcione novamente como matéria-prima e ingresse novamente nos meios de produção. Dessa forma o espaço socialmente produzido, tanto do território da concessão urbanística quanto do seu entorno, ingressaria no processo produtivo como meios de produção e se tornariam fatores objetivos para o trabalho vivo. Essa apropriação do espaço pelo trabalho vivo somente ocorre quando as condições reais tornam possíveis à apropriação privada do espaço para converter aquilo que está posto como deteriorado e desvalorizado em valores que se efetivam sob novas formas de uso.

Os conceitos que atravessariam a concessão urbanística Projeto "Nova Luz" seriam aqueles ligados a uma estética específica, ou seja, a um conjunto de representações ideológicas capazes de atribuir ao espaço (somadas às formas de intervenção e transformação morfológica do espaço, levando em conta a mudança da paisagem) e aos lugares, novos valores de uso.

Os mecanismos para a produção dessas novas representações são elencados no próprio projeto urbanístico específico. Por exemplo, no caso da arquitetura dos edifícios, por meio: 1) da alteração do seu coeficiente de aproveitamento, neste caso aplicando a norma que também

\footnotetext{
${ }^{173}$ Reprodução da metrópole, se levarmos em conta que se tratava da reprodução de um fragmento que comporia o movimento da valorização diferenciada dos lugares da metrópole; reprodução dos espaços de lazeres, afinal, por meio de um projeto todo estruturado em âncora que seria capaz de hierarquizar o espaço diferenciando por completo o que seriam os espaços de lazer, consumo e moradia, o projeto também tinha como finalidade reproduzir a própria cotidianidade ao direcionar os espaços e, consequentemente, a prática socioespacial dos indivíduos. Nestes termos, a fragmentação manteria uma unidade específica por meio do homogêneo e a estética (provavelmente caracterizada também a partir da forma-mercadoria) unificaria os fragmentos por meio da produção de novas representações para o espaço, dissimulando sua homogeneidade, fragmentação e racionalidade instrumental dominante e dominadora; tudo sob a permissão, dominação e determinação do Estado.
} 
está para a Operação Urbana Centro ${ }^{174}$; 2) na heterogeneidade das fachadas, o que demonstra a tentativa de empregar a este lugar, do ponto de vista do plano abstrato, certa diversidade visual através das estruturas arquitetônicas; 3) na diferenciação dos volumes que compõe as edificações; 4) na altura do pavimento térreo que permita o uso comercial; 5) no terraçojardim nas edificações, o que imprime ao lugar mais do "elemento verde"; 6) na constituição de varandas nas edificações, permitindo as pessoas verem e serem vistas, aumentando a sensação de segurança; e nas fachadas transparentes, onde as vitrines dão o ar da graça do consumo. E, no que tange ao exemplo do projeto urbano para o lugar, tem-se: 1) no referencial urbanístico com a valorização das esquinas, transferindo a mesma lógica das edificações, por meio dos usos; 2) na implantação de pátios internos nas quadras, cuja finalidade é constituir um espaço de lazer privado, de acesso controlado ao público; 3) na implantação de edificações sem recuos, com fachada associada a calçada; 4) na implantação de elementos junto às fachadas ${ }^{175}$.

O plano, a partir do que seriam as unidades a serem transformadas, constituiu-se naquilo que tinha como meta mudar o lugar, e para a eficiência esperada do plano em sua (incerta) e futura consolidação, foi proposto a tipologia das quadras, praticamente, os mesmos princípios anteriores que determinavam a morfologia do público e do privado. Seguindo este modelo de constituição das formas arquitetônicas e urbanísticas, as quadras foram caracterizadas em 4 tipologias: 1) permeável: portadoras de atividades não residenciais; 2) Não-permeável, portadoras de uso residencial; 3) Inserção: com empreendimentos localizado em lotes menores de inserção urbana; 4) especial: que acomodam equipamentos culturais e patrimônio histórico, considerados como estratégicos.

A estratégia em torno da valorização do patrimônio histórico, para além de assegurar a identidade do Centro metropolitano de cidade global, assegura também os conteúdos que fundamentam no espaço a sua própria revalorização. Mais do que a preservação do valor histórico e cultural, e de seus referenciais como morfologia urbana (traçado urbano e identidade de bairro), a estratégia do patrimônio cultural, de fato, revela uma lógica de valorização da propriedade privada do solo urbano que se encontra em suas adjacências. Para

\footnotetext{
${ }^{174} \mathrm{Na}$ Operação Urbana Centro, o coeficiente de aproveitamento do terreno corresponde à permissão de construir uma densidade seis vezes maior que a área do próprio terreno destinada à edificação. Assim, quanto maior a área do terreno, maior o tamanho do edifício e seu número de pavimentos. Conforme os cálculos e as exigências na lei que atravessa a Operação Urbana Centro, levando em conta garagem, serviços e outras partes do edifício não residencial, o coeficiente de aproveitamento pode chegar até o valor de 18,0 (como é o caso para o uso de hotel de turismo que ficam no perímetro da Operação Urbana Centro, mas ficam fora do perímetro das áreas de especial interesse). Para os edifícios residenciais, o coeficiente de aproveitamento poderiam atingir os índices de 2,5 e 4,0.

${ }^{175}$ Projeto Urbanístico Nova Luz, p.105.
} 
Kara-José, (2007, p. 154) este seria uma espécie de "efeito dominó", pois, na medida em que a comunidade passasse a valorizar o patrimônio restaurado, o valor imobiliário dos edifícios restaurados e de seu entorno também tenderiam a aumentar. Porém, neste regime de privatização do espaço, além desta dimensão de valorizar o entorno, o patrimônio histórico tombado exige também a sua manutenção, portanto, uma espécie de controle sobre a edificação que seria, também, um controle sobre o espaço.

Ao planejar as formas de uso e ocupação do solo, a estratégia desarticula e estilhaça o espaço por meio de uma coerência que produz uma unidade fictícia. No caso do Projeto "Nova Luz", a empresa buscava também se apropriar das condições políticas ligadas ao álibi cultural para promover as formas de revalorização do espaço por meio da complementaridade de características diversas (cultura, espaço público, polo de comércios e serviços etc.). Ao elaborar um plano de uso e ocupação do solo, a estratégia tenderia a se realizar na minúcia da produção de espaços a partir do fundamento abstrato da racionalidade técnica que, por meio de algumas exigências específicas, reconduziria as relações sociais no espaço por meio das estruturas que caracterizariam o lugar.

Do ponto de vista dos investimentos e de reprodução do capital, tanto a elaboração do projeto quanto os estudos de área do Projeto "Nova Luz" deveriam de caracterizar, na política de concessão urbanística, a viabilidade econômica e financeira dos empreendimentos que estavam nos planos de execução. Entretanto, os próprios mecanismos de obtenção de receitas por meio da concessão apontavam novas formas tanto de acumulação quanto por meio de realização de novas formas de segregação socioespacial, a partir do momento em que no território delimitado algumas atribuições ao concessionário seriam possibilitadas. Nesse caso, seria por meio da exploração dos imóveis resultantes dos lugares a serem transformados que a concessionária garantiria seus rendimentos. Ao reproduzir praticamente todo espaço dentro deste território estratégico, a concessionária promoveria também o desenvolvimento imobiliário (por meio de imóveis residenciais e não-residenciais) e, consequentemente, a revalorização do espaço.

A tendência dos negócios voltados à urbanização destes territórios estratégicos é que a revalorização se realize de maneira progressiva no tempo e, no espaço, de maneira ampliada, atingindo os espaços do entorno do território estratégico. Seria por meio da promoção de um desenvolvimento imobiliário que, possivelmente, haveria a valorização dos terrenos, o que resultaria na atividade econômica capaz de remunerar o concedente; ou seja, a compra dos terrenos e a negociação de parceiros incorporadores dos imóveis, visando sempre o mercado. 
A receita, conforme aponta os estudos de viabilidade ${ }^{176}$, decorreriam dos projetos imobiliários que seriam definidos para o lugar e estes, por sua vez, estimaria o preço da venda dos terrenos e a obtenção de rendimentos do concessionário.

O valor do terreno ou, o valor da propriedade privada do solo urbano, torna-se um fator essencial para este mecanismo de reprodução pelo fato de que a forma propriedade privada do solo urbano, no regime de concessão urbanística do espaço, desvincula, aparentemente, a produção imobiliária da dinâmica de liberação e revalorização dos terrenos. A separação entre o regime de concessão e as atividades de desenvolvimento imobiliário, constantemente são destacadas no documento, buscando sempre salientar que

\begin{abstract}
a concessionária pode negociar parcerias para a incorporação, cabendo a si a parcela econômica correspondente ao valor do terreno no negócio. Ou seja, o valor do terreno traduz a parcela de receita que reflete as atividades geradas como obrigações da concessionária, separando-a da atividade de produção imobiliária, que tem sua dinâmica própria e requer uma gestão de riscos e expectativa de remuneração distintas ${ }^{177}$. Meus grifos.
\end{abstract}

Ao afirmar que a produção imobiliária possui uma dinâmica que é própria, a concessionária se afasta de qualquer possibilidade de a ela ser atribuída possíveis acusações de aumentar significativamente o valor do espaço nestes territórios de intervenção. Por conseguinte, em função desta afirmação de que o concessionário não guarda nenhum vínculo com as atividades de produção imobiliária e formas de especulação por meio de aumento significativo dos preços do metro quadrado, qualquer supervalorização que possivelmente viria a acontecer não estaria atrelada ao concessionário, mas sim ao incorporador e/ou agente responsável pela produção imobiliária no território de intervenção.

Este mecanismo de intervenção faz com que a propriedade privada do solo urbano se desvincule daquele proprietário que atribui a esta forma a primazia do valor de uso e, ao passar para a empresa capitalista, o valor de uso do espaço se realiza enquanto valor de troca através desta produção específica. Ao fechar a parceria com o incorporador imobiliário e ofertar a este todas as condições para a produção de um produto específico (inclusive a propriedade privada do solo urbano), os rendimentos obtidos por meio da reprodução do espaço resultariam das suas diversas formas de exploração por meio de contratos temporários de usos de seus produtos espaciais. Assim, o próprio processo de revalorização se

\footnotetext{
${ }^{176}$ Estudo de viabilidade, p. 149.

177 PROJETO NOVA LUZ - Estudos de viabilidade econômica, mercadológica e de situação fundiária consolidados. Subproduto 5.6, p. 115.
} 
encarregaria de auferir para o concessionário o mais-valor ${ }^{178}$ e o sobre-valor ${ }^{179}$ através de condições de exploração privada do espaço urbano, historicamente e socialmente produzido.

A concessão de fragmentos estratégicos do espaço, enquanto instrumento urbanístico institucionalizado e legal que é, consiste numa forma em que os mecanismos de intervenção na cidade constituem-se em ferramentas que são capazes de acumular a propriedade privada do solo urbano. Nestes territórios, quando o concessionário tem total liberdade do Estado, a tendência posta é que, cada vez mais, haja uma espécie de acumulação da propriedade privada do solo urbano para os domínios do Estado. As receitas obtivas naquilo que é chamado de valor terreno, consistiria em formas de obtenção de renda por meio de uma espécie de "aluguel" do valor de uso atualizado deste terreno transformado. Não ocorre, de fato, uma venda efetiva dos terrenos, mas sim a venda do seu valor de uso conforme a sua estrutura atualizada para aquela forma de uso decorrente das constantes transformações no espaço, logo, a sua reprodução. O que é posto em estado de alienação nesta forma atual de exploração capitalista do espaço são as formas de uso dos lotes e das estruturas arquitetônicas que os caracterizam. Esta é a forma que caracteriza o Projeto Urbanístico Específico do "Nova Luz", em que o espaço público passa a ser alvo de soluções específicas e o espaço privado é identificado a partir de novas regras de ocupação ${ }^{180}$. Ou seja, nestas novas formas de ocupação dos territórios sob o regime de concessão, a propriedade privada do solo urbano passa a ser a forma que se realiza em um regime constante de suspensão, ficando esta a cargo do Estado e dos concessionários, conforme as necessidades específicas de seu direcionamento e gestão. Ainda vale destacar, para critérios de reforço das nossas considerações feitas linhas acima, um trecho do documento que é significativo para esta interpretação dos fatos:

No entanto, cumpre ressalvar que a responsabilidade da concessionária, nos termos do contrato de concessão, não estará relacionada à venda de terrenos. Dessa forma, mesmo que, apenas para efeito do modelo, tenha sido adotada a hipótese da alienação, por parte da concessionária, de todos os lotes disponíveis, continuariam cabendo a ela, até o final do período de concessão, as obrigações estabelecidas no respectivo contrato, tais como: (i) a efetivação da transformação urbanística dos terrenos privados, ainda que autorizadas as diversas formas de parceria e contratos civis admitidos na legislação (ii) a realização de todos os investimentos para execução das intervenções objeto da Concessão Urbanística e

\footnotetext{
${ }^{178}$ Neste caso, decorrente do diferencial de investimentos para produzir o espaço.

${ }^{179}$ Decorrente do processo progressivo de revalorização que tenderia a ocorrer em cadeia, conforme a totalidade dos investimentos privados nas formas de acumulação que surgiriam a partir da reprodução doe espaço.

${ }^{180}$ PREFEITURA DE SÃO PAULO. Secretaria de Desenvolvimento Urbano. Projeto Urbanístico Específico (PUE). Subproduto 5.1: PUE Consolidado. Projeto NOVA LUZ, São Paulo, Brasil. Julho de 2011. Partido Urbanístico, Introdução.
} 
previstas no projeto urbanístico específico; (iii) o pagamento, por sua conta e risco, das indenizações devidas em função da realização de desapropriações para a aquisição de imóveis necessários à execução do projeto urbanístico específico; e iv) o custeio de toda uma equipe própria necessária para o acompanhamento e implantação do projeto urbanístico específico e das medidas mitigatórias previstas no EIA-RIMA. Meus grifos.

A ressalva feita no projeto nos deixa claro qual a lógica se encaminha para as políticas de intervenção no espaço neste inicio de século, pois, a partir do momento em que a hipótese da alienação dos produtos se realiza apenas enquanto um modelo de exemplificação de mecanismos de obtenção de rendimentos, o que realmente estaria em jogo seriam as formas de contrato temporário para as formas de uso de boa parte dos espaços construídos neste território estratégico. Caberia ao concessionário, constantemente e conforme as necessidades postas, elaborar estratégias e pôr em prática a reprodução ininterrupta do espaço levando em conta estes mecanismos de adaptação à realidade passível de acumulação. Isso explica o baixo índice de oferta de habitações que seriam disponibilizadas neste tipo de política, afinal, sua lógica vai na contrapartida das vendas da propriedade privada do solo urbano, e leva em conta as vendas de suas respectivas possibilidades de uso, ou seja, uma espécie de aluguel, considerada no documento como receita da comercialização das unidades imobiliárias ${ }^{181}$. No documento, o Valor Geral Das Vendas (VGV) torna-se um referencial para projetar as probabilidades de receitas que seriam obtidas com a comercialização de unidades imobiliárias definidas no projeto urbanístico específico. Por meio da decomposição do VGV entre os empreendimentos residenciais e não residenciais,

os empreendimentos não residenciais representam 72,9\% desse valor $(\mathrm{R} \$ 3,51$ bilhões com base em junho/2010 ou R \$ 3,75 bilhões com base em junho de 2011), enquanto os empreendimentos residenciais representam $\mathbf{2 7 , 1 \%}$ do valor $(\mathrm{R} \$ 1,30$ bilhões com base em junho/2010 ou R \$ 1,39 bilhões com base em junho de 2011) ${ }^{182}$. Meus grifos.

O regime de concessão urbanística de fragmentos estratégicos do espaço consiste num mecanismo de revalorização do espaço caracterizado por um processo de continuidade progressiva de valorização do valor. Praticamente duas frentes atuariam em sinergia para este processo de reprodução do espaço: uma na figura do concessionário, responsável por adquirir, demolir, limpar e vender os terrenos (neste caso, a venda ligada às unidades residenciais), e

\footnotetext{
181 PROJETO NOVA LUZ - Estudos de viabilidade econômica, mercadológica e de situação fundiária consolidados. Subproduto 5.6, p. 119.

${ }^{182}$ Ibidem, p. 120.
} 
outra na figura do parceiro incorporador/construtor, responsável por construir e vender e/ou comercializar os imóveis; ao morador/empresas, caberia habitar (no caso da compra do imóvel residencial), operar, explorar comercialmente os imóveis. Levando em conta que o consórcio se realiza por um longo período de tempo, consequentemente, ocorre que as conjunturas de valorização dos empreendimentos imobiliários tendem a mudar, o que exigiria uma constante reprodução do espaço conforme as necessidades de adaptação para a acumulação. Assim, três aspectos caracterizam estes que são chamados de cenários para a valorização $^{183}:$ 1) a mudança da configuração dos edifícios do Centro de São Paulo e seu entorno (fator que abrange as transformações para além do território de intervenção, neste caso, abrangendo o espaço); 2) as mudanças na quantidade e localização das amenidades da que estão neste fragmento da metrópole (ou seja, as transformações decorrentes das conjunturas sociais que ocorrem no espaço); 3) a melhoria da imagem do Centro e seu entorno, como um espaço que é concebido em função de suas condições atuais (nesse caso, inerentes às transformações sucessivas da paisagem).

A delimitação estratégica de um fragmento do espaço urbano revela, por meio das políticas urbano-territoriais na atualidade, as formas que visam reverter o "impasse" da propriedade privada do solo urbano através do pleno controle desta por parte da iniciativa privada. Ao centralizar em si o maior número possível de propriedades, permitindo o controle de suas alterações e valorização, o resultado que se tem de maneira gradativa no espaço é o de sua valorização progressiva e, consequentemente, do crescimento exponencial da segregação socioespacial. Enquanto instrumento de promoção do processo de urbanização, a concessão urbanística adquire potencialidades e poderes que, para além de fomentar a produção do espaço para sua apropriação privada por via da compra e/ou comercialização de unidades, são capazes de promover formas atuais de realização de negócios por meio da privatização do espaço.

Nos termos de realização deste instrumento urbanístico, a metrópole, em um contexto reprodutivo, torna-se, cada vez mais, força produtiva, pois, o ciclo de rotação de capital, por este mecanismo de produção do espaço, tende a se encurtar devido as possibilidades comerciais que surgem de todas suas instâncias. No caso da concessão urbanística, o uso do espaço em todas suas dimensões é submetido ao processo de reprodução e caracterizado nessas novas formas de controle, direcionamento e regulamentação do espaço. Ao conceder para a empresa privada os poderes de direcionamento do processo de urbanização em um

${ }^{183}$ Ibidem. 
fragmento específico e estratégico da metrópole, o Estado contribui (e ao mesmo tempo fomenta) com as condições para que a metrópole se transforme em força produtiva, por meio das redefinições e reorganizações constantes do espaço. Sob o controle do Estado e concedida à iniciativa privada, a propriedade privada do solo urbano tende a entrar, talvez, num estágio que até então não havia entrado: aquele em que sua existência torna-se o fundamento instituído e reconhecido socialmente para a reprodução capitalista do espaço.

De início, quando abrimos este subcapítulo enfatizando que a concessão urbanística Projeto "Nova Luz" consistia numa política embargada pelo poder judiciário, não faria muito sentido tecer algumas considerações sobre uma política que não existia mais. Porém, quando olhamos para o nosso horizonte próximo e vislumbramos um amplo recorte de intervenção caracterizado por esta forma de política urbano-territorial (o "Arco do Futuro" e/ou a Macroárea de Estruturação Metropolitana), algumas perspectivas de vislumbrar a problemática podem ser de boa ajuda para refletir sobre o devir da reprodução capitalista da metrópole.

No regime de concessão urbanística, algumas formas necessárias para o processo de urbanização capitalista acabam sendo postas em estado de suspensão, exatamente porque, sob o controle e domínio do Estado, elas tendem a continuar-se reproduzido através do fundamento e primazia do valor de troca. O território urbanístico do Projeto "Nova Luz" consistiria numa política em que uma parcela significativa do Centro de São Paulo, para fins de ser explorada comercialmente, passasse para a iniciativa privada que então teria alguns poderes e domínios para realizar neste espaço a sua reprodução com conteúdos que se realizariam apenas em função do valor de troca.

O regime de concessão urbanística ainda continua em voga como um dos instrumentos que compõe o sistema de ordenamento e reestruturação urbana da Prefeitura, para fins dos chamados projetos de intervenção ${ }^{184}$. Ao promover este tipo de concessão para a realização do processo de "revitalização" do Centro de São Paulo, o Estado põe em movimento uma modalidade específica de privatização do espaço que, além de permitir que o concessionário explore por um período significativo essa parcela do espaço (geralmente no prazo de trinta anos), o que passa a ocorrer é que no território onde são desenvolvidas essas novas atividades econômicas, a propriedade privada do solo urbano tende a ser acumulada também no domínio do concessionário, por mais que estas ainda fiquem sob o regime oficial de propriedade do Estado. Enquanto instrumento urbanístico regularizado, a concessão urbanística potencializa

${ }^{184}$ Conforme o parágrafo $5^{\circ}$ do artigo 134 do PDE de 2014. 
ainda mais as formas de acumulação através de estratégias atuais que reproduzem o espaço à luz dos imperativos do valor de troca e da forma-mercadoria.

\subsection{6. "Arco do Tietê""}

O "Arco do Tietê" consiste numa unidade territorial justificada como um espaço de intersecção de dois eixos estruturantes na cidade de São Paulo: as Operações Urbanas Consorciadas Diagonal Norte e Operações Urbanas Consorciadas Diagonal Sul. Estas duas operações urbanas (e outras que também compõem o $\S 2$ do mesmo artigo), previstas no Plano Diretor Estratégico de 2002, deram lugar, no Plano Diretor atual ${ }^{185}$, para o conjunto de intervenções intitulado "Macroárea de estruturação metropolitana", mais especificamente em seu "Setor Orla Ferroviária e Fluvial ${ }^{186 "}$. Ainda em fase inicial, o método de atração de investidores privados se realiza por meio de edital de chamamento em que a primeira fase consistiu nos estudos de pré-viabilidade e a segunda fase, atual, consistiu (e ainda consiste) na elaboração de estudos técnicos de viabilidade do desenvolvimento urbano do território do Arco do Tietê, com vistas a transformação urbana desta região ${ }^{187}$.

Figura 9 - Território do "Arco do Tietê" e a fração dos distritos Bom Retiro, Pari e Brás.

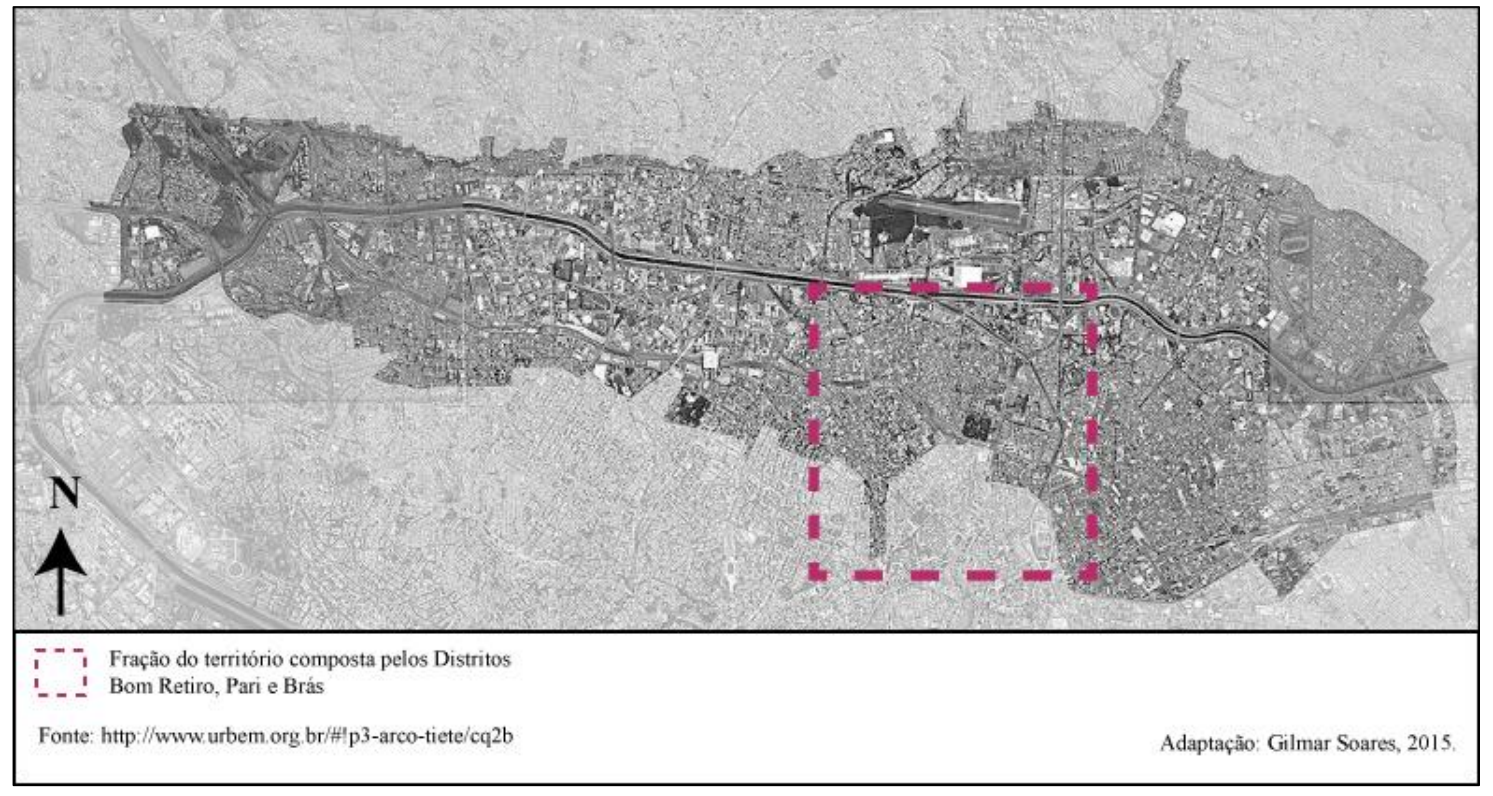

\footnotetext{
${ }^{185}$ Conforme o Artigo 12 da Lei no 16.050 de 31 de Julho de 2014.

186 Segundo o (COMUNICADO DE CHAMAMENTO PÚBLICO No $1 / 2013$, p. 5), conforme os termos do projeto de lei para a revisão do PDE de São Paulo, o Arco do Tietê encontra-se inserido em sua totalidade na Macroárea de Estruturação Metropolitana, o que o qualifica com um território de análise e de estruturação de suas redes de infraestrutura (hídricas, ambientais, viárias e de mobilidade) mediante diferentes instrumentos urbanísticos e políticas urbanas. Isto significa tornar o Arco do Tietê um campo de estudos e de planejamento urbano sobre o qual serão aplicadas as políticas públicas de intervenção. Condição que permite definir quais os melhores instrumentos e quais os melhores mecanismos de controle e gestão são adequados e consistentes para a implantação do projeto. Meus grifos.

${ }^{187}$ Ibidem.
} 
Fato atual, as estratégias voltadas para a macroárea de estruturação metropolitana caracterizam os mecanismos atuais por meio do qual o Estado abre caminho para a iniciativa privada produzir o espaço urbano e, ao mesmo tempo, reproduzir a metrópole. Compreender a reprodução da metrópole e, ao mesmo tempo, a produção política do espaço pelo Estado, é compreender o movimento das instituições e das políticas que o compõe. A relação entre Estado e iniciativa privada, cada vez mais comum no chamado período neoliberal, revelam os mecanismos em que a reprodução da metrópole torna-se dirigida pela iniciativa privada num processo em que a cidade não se torna empresa, mas sim o fundamento dos negócios imobiliários. O movimento iniciado há pouco tempo pela maneira como tendem a se desenrolar as políticas de intervenção no espaço, fazem com que estas revelem os mecanismos do Estado para este tipo de atuação. O "Arco do Tietê" e seu desenrolar inicial, nos aponta o desenrolar de novas estratégias para entregar o espaço à iniciativa privada e produzi-lo como uma das mais (ou talvez a maior) das mercadorias que podem ser consumidas, afinal, o espaço é também o espaço do desejo.

\section{Mapa 3 - Macroárea de Estruturação Metropolitana e Operação Urbana Centro}

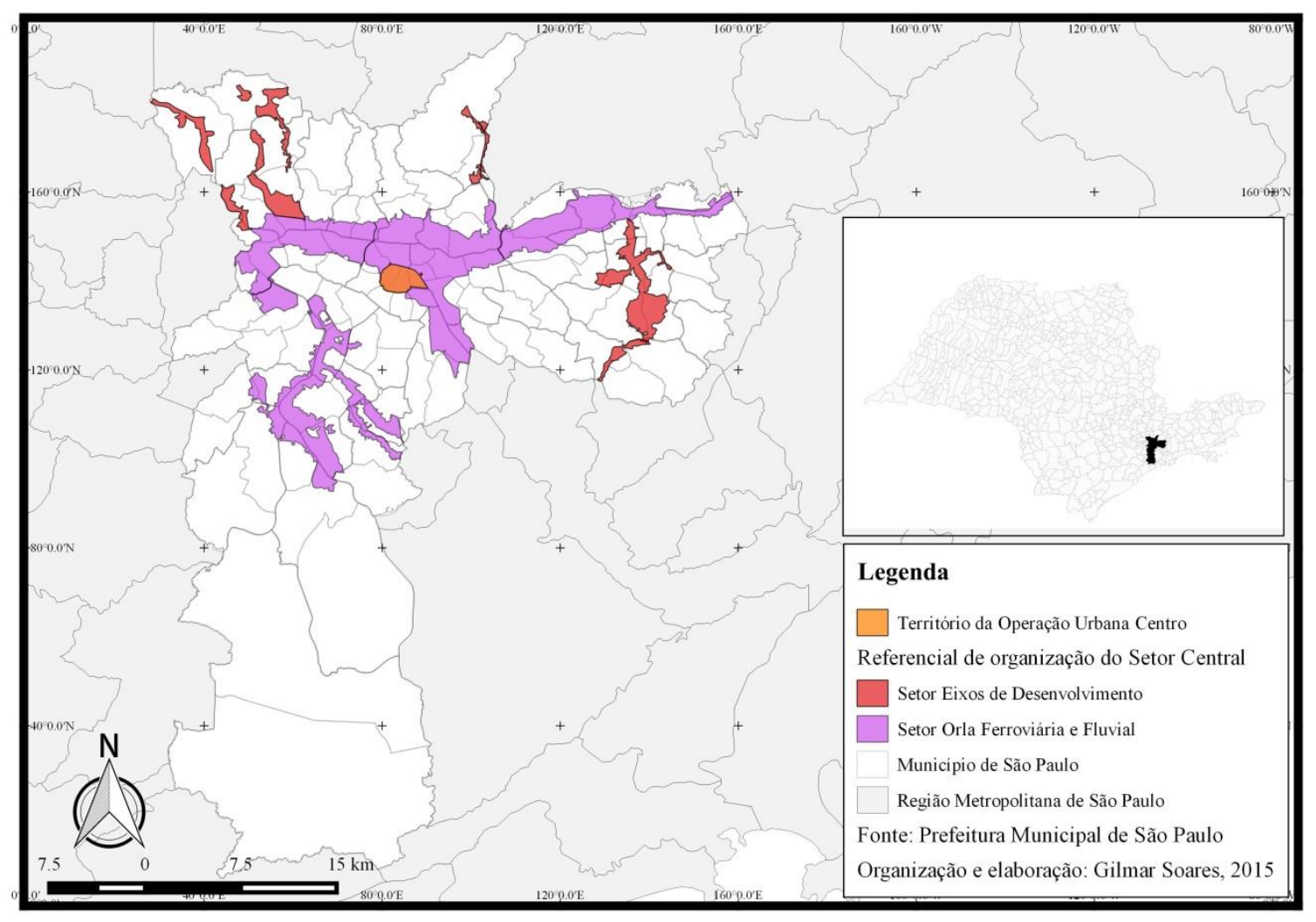


O projeto "Arco do Tietê", abarca uma fração do território que atravessa os distritos do Bom Retiro, Pari e Brás. Se considerarmos os polos de centralidade postos a partir desta política, o Centro de São Paulo e seu entorno constituem, talvez, aquele que é um dos pontos mais importantes desta política.

O Edital de Chamamento consiste em uma das fases do chamado Procedimento de Manifestação de Interesses $(P M I)^{188}$ que consiste numa forma jurídica em que a iniciativa privada subsidia o Estado na estruturação (e/ou produção) de empreendimentos. As análises dos projetos advindos dos interessados consistem em 04 setores prioritários, baseadas em caráter conceitual e propositivo, que visam transformar o território do Arco do Tietê ${ }^{189}$.

Enquanto um objeto a ser empreendido pelo setor privado, o espaço socialmente produzido torna-se, literalmente, privatizado. Dos 04 setores prioritários, alguns modelos norteiam os critérios do Estado: 1) modelo urbanístico; 2) os estudos socioeconômicos; 3) a modelagem jurídica (que entra em consonância com o modelo urbanístico); 4) os meios de interação social ${ }^{190}$. Pelo menos nestas primeiras fases, o chamamento de projetos elaborados pela iniciativa privada condiz com a lógica em que o espaço urbano socialmente produzido, de fato, é entregue ao setor privado. Além de produzir por completo este espaço, controlando e regulando tanto o espaço público quanto a venda do espaço privado, portanto, fomentando as formas já consolidadas de apropriação privada do espaço, tudo leva a crer que, por meio da articulação entre as estratégias dos instrumentos urbanísticos (operações urbanas, IPTU progressivo, Outorga Onerosa do Direito de Construir ou Direito de Superfície, delimitação de territórios estratégicos etc.) e as estratégias políticas, que derivam do próprio aparelho de Estado e se realizam considerando o instrumental técnico que fundamenta o instrumental urbanístico (Consórcios Públicos, Empresas Púbicas, Concessões Urbanísticas, Permissões, Parcerias Público-Privadas e outras), o Estado atualiza a produção do espaço fazendo com que esta se realize por mecanismos capazes de promover formas de privatização do espaço urbano e/ou fragmentos destes espaços na metrópole. .

\footnotetext{
${ }^{188}$ Assegurado pelo Decreto $\mathrm{n}^{\circ}$ 8.428, de 02 de Abril de 2015 o Procedimento de Manifestação de Interesse PMI a ser observado na apresentação de projetos estabelece, levantamentos, investigações ou estudos, por pessoa física ou jurídica de direito privado, com a finalidade de subsidiar a administração pública na estruturação de empreendimentos objeto de concessão ou permissão de serviços públicos, de parceria público-privada, de arrendamento de bens públicos ou de concessão de direito real de uso. Para maiores aprofundamentos, ver este decreto em:

http://www.planalto.gov.br/ccivil_03/_Ato2015-2018/2015/Decreto/D8428.htm.

${ }_{189}$ Metodologia e critérios de aproveitamento de estudos. PREFEITURA MUNICIPAL DE SÃO PAULO, SPURBANISMO, (sem data).

${ }^{190}$ Ibidem.
} 
Se a produção do espaço já garantia a continuidade das formas de acumulação e, ao mesmo tempo, domínio e controle da reprodução, por meio de formas que caracterizam a reprodução da cidade e do urbano, as políticas urbano-territoriais, no caso do Arco do Tietê, apontam um trajeto em que o Estado deixa a cargo da iniciativa privada bem mais do que as condições para a produção e consumo do espaço. Para além de produzir as estruturas urbanoarquitetônicas que caracterizam os lugares da cidade (que nas relações de compra e venda podem ser apropriados privativamente) o Estado transfere à iniciativa privada, através de incentivo a formas de empreendimento, o espaço urbano e sua possibilidade de produção privatizada.

A relação do processo de revalorização do Centro de São Paulo, ou, neste caso, a revalorização da Área Central (que implica também o conjunto de distritos que ficam no entorno dos distritos Sé e República) passa também pela transformação dos conteúdos e representações destes distritos e seus respectivos bairros. Não seria exagero ponderar, talvez, que, se o processo de desvalorização consistiu no movimento em que a centralidade econômica se desdobrou sentido vetor sudoeste da cidade, atualmente, o processo de revalorização do Centro se realiza em um movimento de vêm da periferia para o Centro em que a produção de novos conteúdos não é por completa no sentido de produzir novas centralidades, mas sim produzir novas representações e usos para o espaço.

Questionado sobre se o "Arco do Futuro" e o "Arco do Tietê" são estratégicos e se é o transporte quem poderá determinar o desenvolvimento da cidade, o Sr. Jurandir Fernandes, então Secretário de Transportes Metropolitanos do Estado de São Paulo teceu uma resposta interessante que vale ser reproduzida na íntegra:

Os vazios urbanos, tanto na diagonal Norte, quanto na diagonal Sul, são espaços ocupados no período pós-industrialização da cidade. A cidade de São Paulo, como cidade mundial, tem seu futuro voltado para o setor de serviços. Se conseguirmos ocupar esse espaço de uma forma densa e inteligente, com enterramento de vias, juntaremos dois espaços urbanos com diferenças de potencial. De um lado tem-se a cidade com valorização a partir da marginal em direção ao centro. Do outro lado, está uma área de baixa valorização, de pequena acessibilidade. Com essa articulação entre as duas áreas, com fundos de investimentos, será possível apropriar-se da mais valia e aplicá-la nos investimentos públicos em infraestrutura. Haverá um ganho social enorme, pela eliminação de deslocamentos pendulares irracionais, demonstrando a importância da área do Arco Tietê. Outro aspecto a destacar, é a necessidade de coragem política para fortalecer o transporte coletivo. A própria classe média perceberá as melhorias decorrentes desses investimentos. O 
exemplo é a intervenção que ocorreu no Largo 13 de Maio em que a população é estimulada a fazer a integração de transporte, o que não fazia antes ${ }^{191}$. Meus grifos, tanto em negrito quanto em itálico.

A resposta do Secretário de Transportes Metropolitanos do Estado de São Paulo exemplifica de forma clara como que o espaço, além de estratégico, torna-se "nas mãos do Estado" somente mais uma dimensão manipulável da realidade, cujo processo de produção política revela sua importância e centralidade.

O movimento do processo de (re)valorização é apontado como aquele que vem das marginais em direção ao Centro. Se anteriormente consideramos que o processo de desvalorização do Centro ocorreu em função de uma dialética específica da reprodução do espaço da metrópole, por meio da valorização diferenciada de seus espaços, não seria um exagero em considerar que o processo de revalorização (tanto do Centro quanto dos lugares em que ocorreu o fenômeno da desindustrialização ${ }^{192}$ ) também se constitui como parte de um processo maior, por meio da delimitação estratégica de uma fração significativa do espaço da metrópole que oferece condições à sua reprodução capitalista através dos lugares que apresenta um baixo valor. O que resta é o aproveitamento das estruturas e dos polos de centralidades (os subcentros) já consolidados para o reforço ou mesmo reprodução destas centralidades. Nestes termos, as estratégias do Estado se realizam no nível do lugar, rebatendo diretamente na vida cotidiana das pessoas através das relações que as políticas urbanoterritoriais transformam nesta dimensão imediata da reprodução da cidade.

Ao longo do território do "Arco do Tietê", as relações produtivas diferenciam os lugares, afirmam e confirmam algumas centralidades já consolidadas através de atividades ligadas à indústria, ao comércio e aos serviços. Além dessas características, outros fatores de infraestrutura também caracterizam e conformam estas centralidades, como: a rede de transporte coletivo metropolitano (trens, metrô e linhas de ônibus) praticamente adensado no Centro de São Paulo; o território da macroárea de estruturação metropolitana que atravessa os distritos que compõem a Área Central; a rede hídrica na confluência dos rios Tietê (marginal) e Tamanduateí (Avenida do Estado). Dos subcentros e/ou dos pontos de centralidade que compõem a totalidade do que está posto como o "Arco do Futuro", a relação do Centro de São Paulo com o "Arco do Tietê" talvez caracterize um dos principais pontos de intervenção e de centralidade (ver figura 07) que estão postos pelas políticas de intervenção do Estado.

\footnotetext{
${ }^{191}$ PREFEITURA MUNICIPAL DE SÃO PAULO. Projeto “Arco do Tietê”. Seminário Temático. Registro de reunião: 04/04/2013.

${ }^{192}$ Para aprofundar neste movimento em que os espaços de desindustrialização servem à produção de novos negócios imobiliários, ver Pádua 2011, 2015 e 2015a.
} 
Figura 10 - Pontos de Centralidade do "Arco do Futuro"

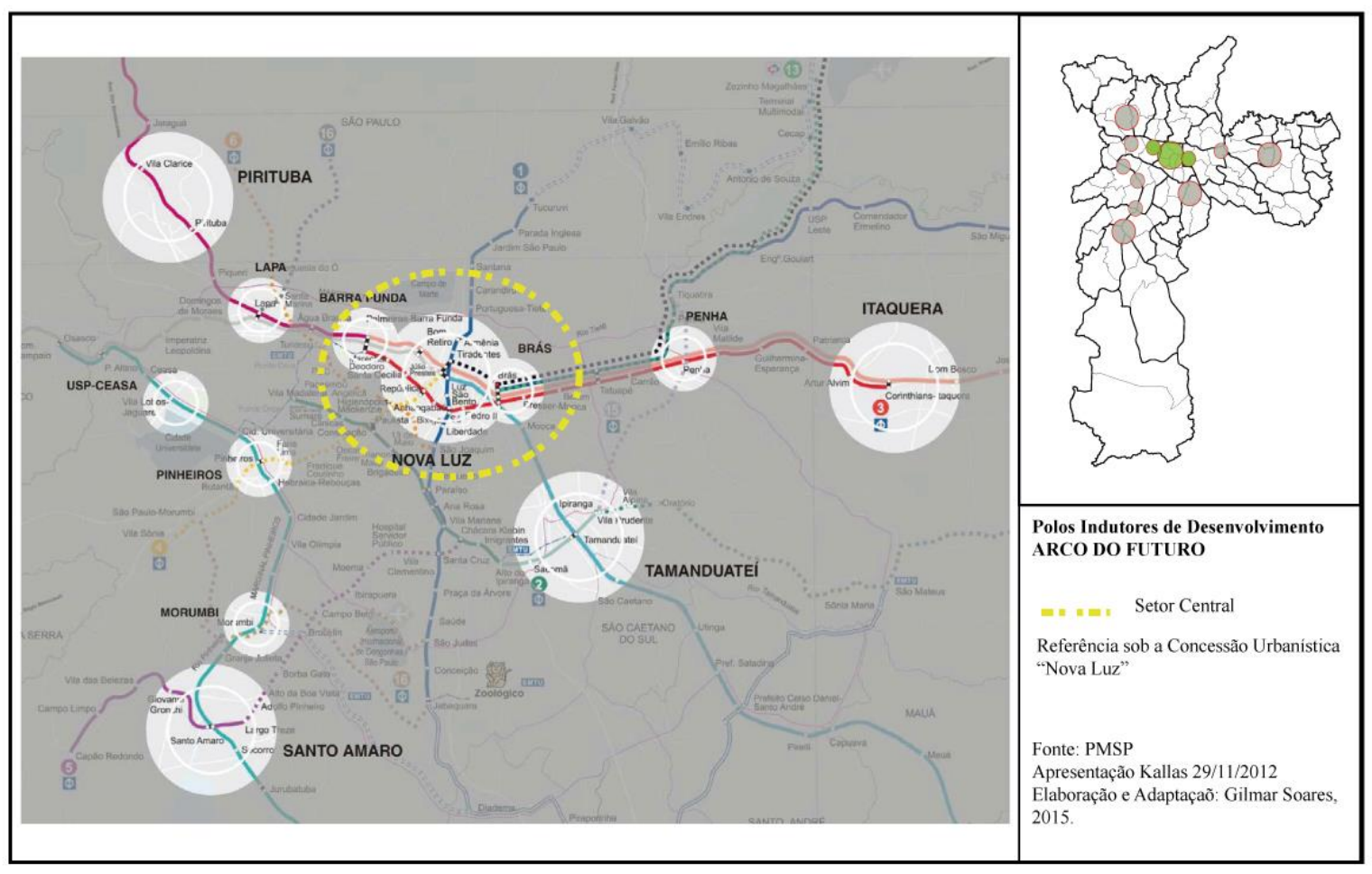

O Centro de São Paulo e seu entorno, mais especificamente os distritos do Bom Retiro, Pari e Brás, por concentrarem atividades econômicas que são historicamente significativas na construção das representações do Centro, caracterizam uma fração estratégica deste território de intervenção por concentrar três eixos que norteiam as propostas encaminhadas para o Arco do Tietê. Para o Estado, na figura de seus agentes que direcionam e põem em prática as políticas urbano-territoriais, São Paulo é tida como uma cidade que deve ser pensada em rede, e que este fator caracteriza algumas centralidades consolidadas no território do "Arco do Tietê", entre essas, o Pari, o Brás, e o Bom Retiro ${ }^{193}$. Visto como um território estratégico, a partir da qualidade e qualificação dos sistemas técnicos, e que tem a capacidade de articulação das centralidades (e/ou subcentros), o "Arco do Tietê", principalmente na fração limítrofe aos distritos Sé e República, é amplamente dotado de infraestrutura e equipamentos urbanos de grande significância para a metrópole.

Conforme a lógica instrumental assentada na figura do Estado, estas infraestruturas tidas como sistemas técnicos devem ser um referencial para se pensar o processo de urbanização, afinal, a qualificação destes sistemas técnicos capacitaria a articulação das

\footnotetext{
${ }^{193}$ PREFEITURA MUNICIPAL DE SÃO PAULO. Projeto “Arco do Tietê”. Seminário Temático. Registro de reunião: 26/04/2013.
} 
centralidades, dos sistemas de espaços públicos e da oferta de lazer, e de qualidade ambiental da cidade, por meio da articulação de projetos especiais neste território (complexo Anhembi, Sambódromo, complexo cultural em torno da Estação da Luz, e complexo de comércio popular Brás-Pari $\left.{ }^{194}\right)$. Segundo o arquiteto Gustavo Partezani Rodrigues, Diretor de desenvolvimento da SP-Urbanismo, torna-se importante repensar a área de várzea para a cidade, ainda mais na fração que fica no entorno dos distritos Sé e República, levando em conta as características de cada distrito. Segundo ele

\begin{abstract}
Os movimentos Pari-Brás são devidos ao circuito de compras. Se conseguirmos entender a importância dos arranjos produtivos, entender que eles devem permanecer no território, que devem ser incrementados, inclusive adicionados por outros, por novas tecnologias de trabalho, emprego e renda, e se entendermos como os deslocamentos ocorrem nesse território, será possível começar a mapear, ou a direcionar o desenho da modelagem urbanística. Em seguida apresentou diretrizes pautadas por três questões que estão presentes no PDE de 2002 e que devem continuar na revisão: a) geografia do território e recursos hídricos; b) mobilidade - sistema viário e transportes e c) centralidades e rede de equipamentos - existentes e as novas que poderão vir $^{195}$.
\end{abstract}

As políticas urbano-territoriais são instrumentos, por excelência, de realização da reprodução da metrópole, pois, se por meio das operações urbanas (consorciadas ou não) o beneficiário sempre foi aquele quem investia na produção do espaço, levando em conta os produtos imobiliários específicos; agora, com o regime de concessão em que as propostas e as empresas interessadas devem considerar o quadro legal da legislação urbana vigente ${ }^{196}$, o espaço todo torna-se objeto de intervenção da iniciativa privada que, consequentemente, tende a influenciar diretamente na produção dos conteúdos do processo de sua revalorização

Assim, além da produção do espaço, a tendência é que seu controle, regulamentação e direcionamento também fiquem a cargo da iniciativa privada. Contudo, a dominação ainda se realiza pelo Estado, e é por meio desta que sua problemática é fundamentada nesta pesquisa: ao dominar o processo de reprodução da sociedade pela via política (ligada à manutenção das

\footnotetext{
${ }^{194}$ Ibidem, p. 5.

195 Ibidem, p. 3.

${ }^{196}$ A respeito da legislação urbanística aplicável para as propostas, deve se levar em conta que todas as propostas a serem formuladas deverão considerar o quadro legal de regulação urbana vigente, em especial as disposições do Estatuto da Cidade (Lei Federal $n^{\circ}$ 10.257/2001), do Plano Diretor Estratégico do Município de São Paulo (Lei $\left.n^{\circ} 13.430 / 2002\right)$, da Lei no 13.885/2004 e legislação correlata que disciplinam a área de intervenção, podendo ser proposto o uso dos instrumentos jurídicos pertinentes e sugeridas eventuais mudanças na legislação municipal que se mostrem necessárias à implantação do projeto urbanístico, considerando-se, ainda, a Revisão do Plano Diretor Estratégico que ocorrerá no presente ano (COMUNICADO DE CHAMAMENTO PÚBLICO N. ${ }^{\text {1 }}$ /2013/SMDU, p.6).
} 
diversas formas de violência institucionalizada), o Estado o realiza também pela via da reprodução da metrópole; nestes termos, o processo de urbanização transforma-se na mediação em que faz parte também a reprodução das classes sociais e das suas relações baseadas nas tensões pelos interesses opostos, na forma de conflitos que geram decorrem tensões, e da maneira em que estas se revelam.

Enquanto as políticas urbano-territoriais ligadas ao "Arco do Tietê" constituem-se como estratégias que também contribuem com o processo de revalorização do Centro de São Paulo, elas também acabam se articulando com outras políticas urbano-territoriais, seja com a Operação Urbana Centro (um dos setores de estruturação da Macroárea de intervenção do Estado), ou mesmo com a PPP Casa Paulista. No caso da Parceria Público-Privada ligada à habitação e promovida pelo Governo do Estado de São Paulo, esta foi objeto de discussão do Seminário Temático do Projeto "Arco do Tietê", registrado na reunião de 09 de Abril de 2013. Aprofundaremos mais na PPP Casa Paulista na próxima e última política urbanoterritorial a ser exposta nesta dissertação.

\subsubsection{PPP Casa Paulista - Habitação na Área Central da cidade de São Paulo}

A Parceria Público-Privada Casa Paulista consiste em um projeto do Governo do Estado de São Paulo para promover, por meio desta forma de atuação com a iniciativa privada, a construção de unidades habitacionais populares, conforme diversas faixas de renda, nos distritos que compõem a área central da cidade de São Paulo. O pressuposto do projeto na área central ${ }^{197}$ da cidade de São Paulo consiste em viabilizar a oferta de unidades habitacionais de interesse social, levando com conta o grande número de imóveis subutilizados nos respectivos distritos. A estratégia para a realização deste objetivo tem como referência a

localização de oportunidades para intervenção de uma parceria público-privada, voltada à requalificação da área a partir da oferta de habitação, além de incrementos à qualificação dos espaços públicos, dos equipamentos sociais e da otimização da oferta de transporte coletivo ${ }^{198}$.

$\mathrm{Na}$ esteira, e seguindo a lógica do Estado gerido conforme uma empresa, a política é gerida pela COMPANHIA PAULISTA DE PARCERIAS - CPP que integra indiretamente a administração do Estado de São Paulo. Com o objetivo de colaborar, apoiar e viabilizar a

\footnotetext{
${ }^{197}$ Segundo o CHAMAMENTO PÚBLICO N. ${ }^{\circ}$ 004/2012, são considerados por área central os distritos Sé e República e seus envoltórios Santa Cecília, Bom Retiro, Pari, Brás, Belém, Mooca, Cambuci, Liberdade, Bela Vista e Consolação.

${ }^{198}$ CHAMAMENTO PÚBLICO N. ${ }^{\circ}$ 004/2012, p.1.
} 
implementação do Programa de Parcerias Público-Privadas, o Estado fica encarregado com: 1) a elaboração de estudos técnicos sobre a viabilidade econômica e a modelagem recomendada para a estruturação dos projetos; 2) a instituição da PPP; 3) a locação (ou promessa de locação), arrendamento, cessão de uso ou outra modalidade onerosa, de instalações e equipamentos ou outros bens, vinculados a projetos da PPP; 4) assumir total ou parcialmente direitos e obrigações decorrentes de contratos ${ }^{199}$.

A construção de moradias populares na Área Central da cidade de São Paulo contribui, conforme os documentos, com o processo de revalorização do Centro de São Paulo. Levando em conta o elevado número de cortiços que se encontram nestes distritos, essa primeira oferta de moradias visa, pelo menos neste primeiro momento, reverter a situação que atravessa os cortiços de maneira a revalorizar o espaço a partir da transformação da "paisagem urbana" no Centro historicamente caracterizada pela presença dos cortiços. Além do mais, levando em conta o perfil pobre dos moradores que habitam sob a condição de encortiçados, ou mesmo os moradores de ocupações no Centro, ao propor a Parceria Público-Privada na esfera da habitação (considerada social) o Estado também fomenta todas as condições para que a iniciativa privada realize formas de domínio e controle do espaço, inclusive por meio da dominação da vida cotidiana desses que poderão ser os futuros moradores das unidades habitacionais. Tal domínio pode ser assimilado por meio dos serviços que são postos pelo Estado a partir das concessões, como o financiamento habitacional, a gestão da carteira de mutuários, a administração condominial, o trabalho social de pré e pós-ocupação, a capacitação dos sujeitos para a gestão condominial e outros serviços de apoio que possam surgir conforme as necessidades e demandas. A construção de unidades habitacionais na área central de São Paulo, além de ser uma política pública com objetivos claros na delimitação de territórios específicos acaba sendo também uma forma do Estado se fazer ainda mais presente no dia a dia do proletariado.

A estratégia de intervenção é realizada a partir de 06 diferentes territórios ${ }^{200}$, (Quadro 04) próximo às ferrovias e avenidas de grande circulação, que, segundo o (CHAMAMENTO PÚBLICO N. ${ }^{\circ}$ 004/2012, p.2) “interrompem e desqualificam o tecido urbano, gerando em suas áreas lindeiras imóveis de baixo valor agregado" e, assim, "através do aumento da oferta habitacional, procura-se a requalificação destes espaços degradados e desvalorizados ${ }^{\mathbf{2 0 1}}$ ". Ao

\footnotetext{
${ }^{199}$ ESTATUTO SOCIAL. Companhia Paulista de Parcerias. Documento atualizado conforme Assembleia Geral Extraordinária de 30/04/2014

${ }^{200}$ No edital de chamamento desta política aquilo que consideramos aqui como território é oficialmente chamado de setores.

${ }^{201}$ Meus grifos.
} 
delimitar os territórios estratégicos específicos à construção de habitações populares, o Governo do Estado de São Paulo também avança para os espaços no entorno do Centro de São Paulo que, historicamente, foram ocupados por parcelas significativas do proletariado paulistano.

Por se localizarem próximos às indústrias de transformação (isso durante do período de efetivação da indústria de transformação na cidade, na viragem do século XIX para o século XX e nas primeiras cinco décadas seguintes), houve nestes espaços uma concentração histórica do número de proletariados e, por conseguinte, das habitações em condição de cortiço. Além do mais, por estarem em contiguidade espacial ao Centro de São Paulo (compreendido pelos distritos Sé e República), os recortes territoriais são dotados das condições de infraestrutura que caracterizam o Centro de São Paulo (metrô, trens, ônibus, rede de ensino, rede de saúde, equipamentos culturais, diversidade de comércio e serviços, e proximidade com os postos de trabalho oferecidos). 
Quadro 4 - Territórios de intervenção da Parceria Público-Privada Casa Paulista - Área Central da cidade de São Paulo

\begin{tabular}{|c|c|c|c|}
\hline & \multicolumn{3}{|c|}{ Setores } \\
\hline & A & $\mathrm{B}$ & $\mathrm{C}$ \\
\hline \multirow{13}{*}{ 递 } & $\begin{array}{c}\text { Ferrovia / Setor } \\
\text { Oeste }\end{array}$ & $\begin{array}{c}\text { República / Bela } \\
\text { Visa }\end{array}$ & Liberdade / Brás \\
\hline & $\begin{array}{l}\text { O1 - Bairro Barra } \\
\text { Funda / Santa } \\
\text { Cecilia }\end{array}$ & $\begin{array}{l}02 \text { - Minhocão - } \\
\text { Rua Frederico } \\
\text { Steidel }\end{array}$ & $\begin{array}{l}13 \text { - Brás - } \\
\text { Radial Leste }\end{array}$ \\
\hline & $\begin{array}{l}07 \text { - Pari - } \\
\text { Tamanduateí }\end{array}$ & $\begin{array}{l}03 \text { - Avenida } \\
\text { São João }\end{array}$ & $\begin{array}{l}14 \text { - Liberdade - } \\
\text { Cambuci }\end{array}$ \\
\hline & 08 - Bom Retiro & $\begin{array}{l}04 \text { - Grota do } \\
\text { Bixiga }\end{array}$ & $* * *$ \\
\hline & 09 - Pari & $\begin{array}{l}05 \text { - Bela Vista / } \\
\text { Brigadeiro }\end{array}$ & $* * *$ \\
\hline & $* * *$ & $\begin{array}{l}06 \text { - Ligação } \\
\text { Leste - Oeste }\end{array}$ & $* * *$ \\
\hline & $\mathrm{D}$ & $\mathrm{E}$ & $\mathrm{F}$ \\
\hline & $\begin{array}{l}\text { INDÚSTRIAS } \\
\text { Cambuci / Mooca }\end{array}$ & $\begin{array}{c}\text { Ferrovia / Setor } \\
\text { Leste } \\
\end{array}$ & Indústrias / Belém \\
\hline & $\begin{array}{c}15 \text { - } \\
\text { INDÚSTRIAS } \\
\text { Cambuci / Mooca }\end{array}$ & $\begin{array}{l}10 \text { - Indústrias } \\
\text { Brás }\end{array}$ & $\begin{array}{l}16 \text { - Belém / } \\
\text { Celso Garcia }\end{array}$ \\
\hline & $* * *$ & $\begin{array}{l}11 \text { - Brás } \\
\text { Ferrovia }\end{array}$ & $* * *$ \\
\hline & $* * *$ & $\begin{array}{l}12 \text { - Metrô } \\
\text { Bresser / Radial } \\
\text { Leste }\end{array}$ & $* * *$ \\
\hline & $* * *$ & 17 - Belenzinho & $* * *$ \\
\hline & $* * *$ & $* * *$ & $* * *$ \\
\hline
\end{tabular}

Fonte: Governo do Estado de São Paulo

http://www.habitacao.sp.gov.br/casapaulista/downloads/ppp/edital_chamamento_004_12.pdf CHAMAMENTO PÚBLICO N. ${ }^{\circ} 004 / 2012$

Adaptação: Gilmar Soares, 2015.

O entorno dos distritos Sé e República (que compõem praticamente o núcleo onde o espaço é superedificado), ao se tornarem o objeto de políticas urbano-territoriais que visam o processo de revalorização do Centro de São Paulo, torna-se também objeto direto das formas de especulação que derivam do processo de produção do espaço. A produção de empreendimentos imobiliários se torna, talvez, o componente principal das formas de especulação que derivam deste processo, contudo, o próprio espaço em si, enquanto condição e meio para a realização de novas formas de produção, fomenta a emergência dessas novas especulações. As parcerias público-privadas, ao se interessarem por este tipo de modalidade 
de concorrência via edital, participam diretamente das políticas que, sob o álibi das estratégias e da requalificação do Centro, privatizam diretamente fragmentos significativos do espaço da metrópole, gerindo-o e controlando-o durante um período significativo de tempo.

Figura 11 - Setores de Intervenção: PPP Casa Paulista - Área Central

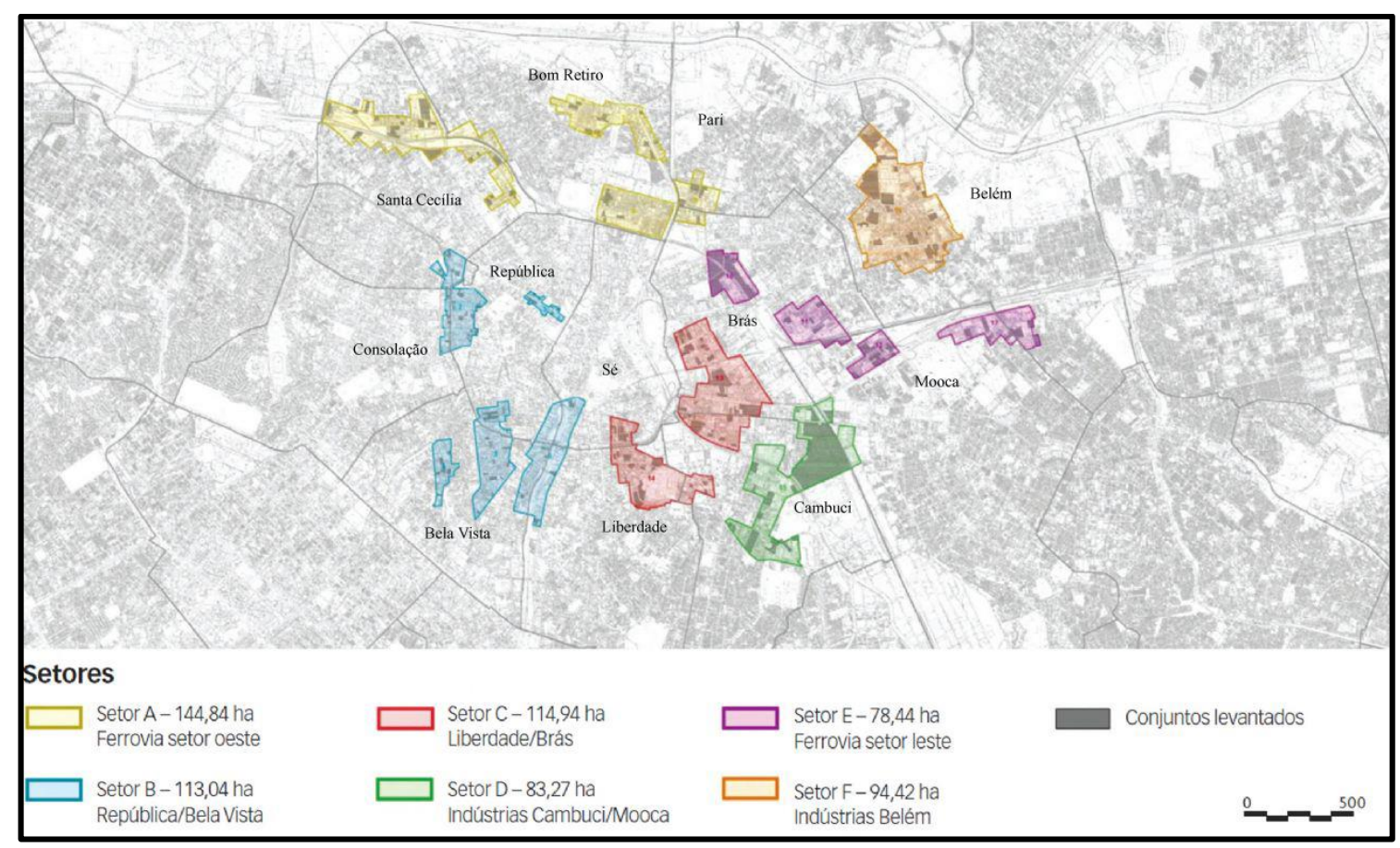

Fonte: http://construcaomercado.pini.com.br/negocios-incorporacao-construcao/133/artigo284029-1.aspx Adaptações: Gilmar Soares, 2015.

Levando em consideração o recorte dos territórios estratégicos para a elaboração da política de moradia nos distritos que compõem a área central da cidade de São Paulo, e levando em conta também as especificidades das políticas urbano-territoriais de revalorização do Centro de São Paulo que avançam para os distritos com baixa densidade populacional e construtiva, o que nos coube nesta pesquisa foi o aprofundamento de análise do avanço (tanto das estratégias do Estado quanto das estratégias da indústria do imobiliário) para os distritos a nordeste do Centro de São Paulo. Assim, Bom Retiro, Pari e Brás seriam como uma nova fronteira urbana de acumulação, através dos lançamentos de novos empreendimentos imobiliários, sejam eles residenciais ou não.

Estrategicamente, também, ocorre que estas políticas habitacionais do Governo do Estado de São Paulo localizam-se nos fragmentos do Centro (e/ou da área central) onde mais se concentram as habitações em condição de cortiço. A nosso ver, fica evidente que a estratégia do Estado para fomentar as relações de compra e venda de produtos imobiliários no Centro de São Paulo (distritos Sé e República) e nos distritos do seu entorno passa, antes de 
qualquer coisa, por transformar significativamente a "paisagem do centro", tido como deteriorado, sujo e desvalorizado.

Caracterizados enquanto lugares do Centro de São Paulo, os territórios caracterizados como A e B compõem este fragmento que, a nordeste dos distritos Sé e República, apresentam maiores possibilidades de avanço e implementação das estratégias de revalorização. Além de reconhecer e destacar o espaço servido de infraestruturas e equipamentos urbanos, enquanto situação existente, o Estado assevera as condições que constituem o desafio à implementação da sua política.

Para o Setor A (chamado de Ferrovia / Setor Oeste ${ }^{202}$ ), estão postos como desafios aquilo que foi chamado como "região da Nova Luz", que no documento foi qualificada por "conhecida como Cracolândia", a Favela do Moinho, e as poucas estruturas atuais que possibilitam a transposição da linha férrea. A diretriz do Setor A foi posta, praticamente, em duas linhas de consideração: a construção de novos equipamentos urbanos e de infraestrutura, e outra vinculada às intervenções específicas que visam formas de valorização. Sobre o primeiro ponto, no Setor A, o Estado propõe a construção de equipamentos que visam a transposição da linha férrea, mobilidade dos pedestres somada às integrações entre as estações de trem e metrô. No que tange as estratégias de valorização, estão postos a requalificação de espaços públicos que valorizem o uso habitacional, o aproveitamento do sistema fundiário caracterizado pela incidência de grandes lotes, a produção de edificações de usos mistos (comerciais e residenciais) e a recuperação (e reconversão) do patrimônio histórico arquitetônico. Sobre o Setor B (República e Bela Vista), talvez aquele que venha a ser o espaço destinado às unidades para as famílias de maior poder aquisitivo, a concentração de equipamentos culturais compõe as estratégias da diretriz para a parceria entre Governo do Estado de São Paulo e iniciativa privada. Além do incentivo aos usos mistos (habitação e comércio) e dos incentivos a produção de estruturas para a mobilidade de pedestres, as diretrizes para a revalorização do espaço são constituídas a partir de estratégias já características que apontamos em outras políticas: de reforma e aproveitamento do potencial histórico-arquitetônico dos edifícios, explorando a identidade cultural e o potencial turístico da área central. No Setor C, denominado Brás - Radial Leste, o território da PPP se articula com o território da Operação Urbana Centro. Para este setor, os "desafios" postos pelo Estado ao concessionário está em produzir estruturas que sejam capazes de superar a barreira

\footnotetext{
${ }^{202}$ Que nada mais é o território de intervenção que acompanha a linha férrea da CPTM ao longo do distrito do Santa Cecília e que se localiza também no distrito do Bom Retiro, nas proximidades do Parque da Luz, do outro lado da Avenida Tiradentes, em um fragmento do bairro do Pari e outra na Avenida do Estado, na junção com a saída da Marginal Tietê.
} 
construída com a interpolação de diversas vias expressas nessa fração do Centro (Avenida do Estado, Rangel Pestana e Radial Leste), aproveitando o potencial posto pelo espaço público do Parque Dom Pedro.

A delimitação estratégica de 06 territórios de intervenção para construção de unidades habitacionais na área central da cidade de São Paulo coaduna com o curso atual das políticas de intervenção neste fragmento da metrópole. Nos territórios da PPP Casa Paulista, além de construir as unidades habitacionais para serem postas à venda, a iniciativa privada ainda terá a concessão do território para ser explorado durante o tempo específico que estará no contrato com o Estado. Como a primeira permissão para a construção de unidades foi assinada no dia 01 de Setembro de 2015, as informações inerentes ao tempo de concessão ainda não foram liberadas. Evidente também que o número de unidades que estão postas para serem lançadas não condiz (Quadro 05) com o número de pessoas que, atualmente, ocupam e sobrevivem (mesmo que em péssimas condições) no Centro de São Paulo. Ou seja, o percentual de unidades habitacionais destinadas a população com faixa de renda de um a dois salários mínimos (isso talvez quando houver possibilidade de compração) acaba sendo bem abaixo da estimativa do número de habitações de interesse social que deveria de existir no Centro de São Paulo.

O fracionamento de unidades específicas conforme as faixas de renda coaduna com as estratégias que, gradualmente, tendem a cambiar também o perfil do morador do Centro de São Paulo. As estratégias de revalorização, nesse caso, também são pautadas pela redução da parcela proletária que atualmente ocupa o Centro, revelando que os mecanismos para a revalorização do espaço se constituem enquanto mecanismos de reprodução que dão continuidade também na reprodução das classes sociais. 
Quadro 5 - Distribuição de moradias por faixa de renda salarial

\begin{tabular}{|l|l|r|r|}
\cline { 2 - 5 } \multicolumn{1}{c|}{} & Faixas de Renda & $\begin{array}{l}\text { Unidades } \\
\text { Habitacionais }\end{array}$ & $\begin{array}{l}\text { Percentual } \\
\text { entre as faixas }\end{array}$ \\
\hline RF1 & $\mathrm{R} \$ 755$ a $\mathrm{R} \$ 1.600,00$ & 3.261 & 16,13 \\
\hline RF2 & $\mathrm{R} \$ 1.600$ a $\mathrm{R} \$ 2.265,00$ & 3.299 & 16,31 \\
\hline RF3 & $\mathrm{R} \$ 2.265,00$ a $\mathrm{R} \$ 3.020,00$ & 2.974 & 14,71 \\
\hline RF4 & $\mathrm{R} \$ 3.020,00$ a $\mathrm{R} \$ 4.068,00$ & 2.974 & 14,71 \\
\hline
\end{tabular}

\begin{tabular}{|c|c|c|c|c|}
\hline RF5 & $\mathrm{R} \$ 4.068,00$ a $\mathrm{R} \$ 7.550,00$ & 3.159 & 15,62 & \multirow{2}{*}{$\sum$} \\
\hline RF6 & $\mathrm{R} \$ 7.550,00$ a $\mathrm{R} \$ 10.848,00$ & 4.554 & 22,52 & \\
\hline & Total & 20.221 & 100,00 & \\
\hline
\end{tabular}

Fonte: Governo do Estado de São Paulo - Secretaria de Habitação

Apresentação da PPP - Habitacional Área Central da cidade de São Paulo. Seminário Arco do Tietê. Legenda:

HIS - Habitação de Interesse Social

HMP - Habitação de Mercado Popular

Data da apresentação 09/04/2013.

Acessado em Novembro de 2014 :

http://www.prefeitura.sp.gov.br/cidade/secretarias/upload/desenvolvimento_urbano/arquivos/arco-

tiete/casapaulista_seminario_arcotiete_20130409.pdf

Organização e adaptação: Gilmar Soares, 2015.

Ao que nos parece, a estratégia de revalorização do Centro de São Paulo tende a se realizar aos poucos, conforme as possibilidades e as "frentes" que surgem evidenciando as formas de privatização do espaço. Nos territórios onde o concessionário atua, além do poder do Estado sobre o espaço, há também o poder concedido à empresa que o explora.

A PPP Casa Paulista ainda está em estágio inicial, contudo, tanto ela quanto o "Arco do Tietê" revelam as novas estratégias do Estado para reverter uma consequência que já é histórica. Outras tentativas foram feitas, como, por exemplo, foi o caso da Concessão Urbanística "Nova Luz", contudo, as condições para este tipo de apropriação via concessão do espaço ainda não eram suficientes. As formas de desapropriação e exploração, escancaradas, eram latentes e implicaram na exposição exacerbada dos conflitos e das formas de resistência que, por sua vez, fizeram com que o Estado e a iniciativa privada recuassem. Tanto a PPP Casa Paulista quanto as outras políticas urbano-territoriais podem ser avaliadas também enquanto estratégias inerentes ao processo de urbanização e sua atualidade. Neste caso, deve ser levar em conta o caráter estritamente capitalista vinculado a este processo, ainda mais quando consideramos a realidade inerente à metrópole. Evidente que a produção imobiliária 
vem, ao longo dos últimos anos (talvez até mesmo das últimas décadas), se configurando como uma atividade produtiva capaz de mobilizar - e ao mesmo tempo pôr em circulação - a uma quantidade significativa de capitais, o que permite a continuidade do processo de acumulação. Assim, somente na conjuntura atual o processo de urbanização se potencializa e adquire novas características (sempre no sentido de permitir a continuidade deste ciclo de acumulação) que vão de encontro ao fomento desta atividade produtiva. A estratégia destas políticas se realiza nestas condições, ou seja, ao mesmo tempo em que elas promovem formas que são propícias à indústria do imobiliário na metrópole paulistana, elas promovem também as condições estruturais ${ }^{203}$ e funcionais ${ }^{204}$ que são capazes de criar mecanismos de ajustes às condições que vão surgindo gradualmente ao longo do processo.

A tendência é que cada vez mais o processo de urbanização se realize por meio da delimitação de territórios estratégicos que produzam formas específicas de privatização do espaço. Portanto, se durante um período - principalmente entre a década de 1990 e 2000 - o processo de urbanização da metrópole promoveu formas que potencializaram a reprodução do seu espaço por meio da produção de novas centralidades que favoreceram a iniciativa privada e seus empreendimentos imobiliários ${ }^{205}$, a tendência é que, ao longo dos anos, principalmente quando vislumbramos àquilo que está posto para o então chamado "Arco do Futuro"206", frações destes territórios estratégicos delimitados por políticas específicas sejam predominantemente geridas integralmente por empresas responsáveis à sua reprodução.

Da mesma forma, não seria exagero também pensarmos que tais estratégias de acumulação vinculadas diretamente ao processo de reprodução da metrópole promovem novas formas daquilo que pode ser considerado, também, como a reprodução da centralidade. No caso do Centro, por exemplo, se o processo de desvalorização (em função da valorização de novos espaços caracterizados por novas centralidades) relativizou a centralidade deste fragmento da metrópole, com as políticas urbano-territoriais, esta tende a "retornar", porém, por meio de novos conteúdos. Assim, no processo de reprodução da metrópole mediado por essas políticas urbano-territoriais, a centralidade é uma forma que se realiza em movimento,

\footnotetext{
203 Ao deliberarem leis que, por exemplo, incentivam a produção de uma quantidade significativa de moradias (ditas populares), contudo, que são predominantemente voltadas para outros segmentos populacionais e que são capazes de mudar significativamente o perfil de moradores ao longo do tempo. Ou mesmo quando promovem políticas urbano-territoriais que se realizam por mecanismos que, explicitamente, promovem formas de privatização do espaço urbano de um fragmento da metrópole; entre outras.

204 Através das modificações no código de obras e edificação, no plano diretor estratégico, nas leis de zoneamento, entre outros.

${ }^{205}$ Principalmente quando consideramos as experiências iniciais ligadas à Operação Urbana Água Espraiada e à Operação Urbana Faria Lima.

${ }^{206}$ Que também pode ter ao longo dos anos uma variedade de nomes que não alterarão em nada sua lógica de funcionamento inerente à lógica do processo de urbanização da metrópole.
} 
principalmente quando levamos em conta que esta reprodução no atual estágio de acumulação (fortemente influenciado pelos conteúdos do processo de urbanização e como que estes também promovem formas significativas de acumulação, principalmente nas metrópoles) estende a forma-mercadoria ao espaço historicamente e socialmente produzido.

Além de promoverem o processo de revalorização do Centro de São Paulo, as políticas urbano-territoriais, enquanto estratégias que são postas em prática pelo Estado, nos apontam também novas tendências que surgem no horizonte do processo de urbanização em curso. Não seria também um exagero apontarmos que tais características denotam como um dos conteúdos que caracterizam a sociedade urbana (em curso e ao mesmo tempo em "gestação"), afinal, as condições históricas para que tais mecanismos e formas de acumulação fossem possíveis, somente foram possíveis após o momento em que a acumulação de capitais por meio da atividade produtiva da indústria de transformação não era mais suficiente para ser realizada na metrópole paulistana. Contudo, o processo de revalorização se realiza também na apropriação dos conteúdos históricos (e, por que não, sociais) do Centro de São Paulo, através do espaço vivido em suas imagens e símbolos, em sua realidade cotidiana e urbana na vida de todos que se apropriam deste espaço, mesmo que em apenas alguns momentos ao longo do dia. Se o Centro da metrópole (bem como seu entorno também) atribuem aos seus usadores formas de representação que vivenciadas nas práticas cotidianas, estas, por sua vez, são apropriadas pelos planejadores para que suas representações sejam renovadas e/ou reproduzidas.

Assim, além das políticas urbano-territoriais, a cultura para a ter uma função preponderante na produção de um novo valor de uso para o Centro de São Paulo, a ponto de, a partir destas, novas formas de dominação - ancoradas por fetiches e ideologias - possam ser postas em prática sob a coordenação do Estado e suas ações em sinergia com as frentes de investimentos de capital. A cultura, até então avalizada como um álibi, passa por um estágio de superação em que a mesma se metamorfoseia no próprio negócio, ou seja, marcada predominantemente pelos conteúdos do valor de troca que passam a se realizar também como fomentadores da reprodução do Centro através do seu processo de urbanização. Veremos um pouco mais desta dimensão na sequência. 


\title{
3.2. A Cultura como estratégia política para a revalorizaÇão estética do Centro de São Paulo
}

\author{
Na época de Homero, a humanidade oferecia-se em espetáculo aos \\ deuses olímpicos; agora, ela se transforma em espetáculo para si \\ mesma. Sua autoalienação atingiu o ponto que lhe permite viver sua \\ própria destruição como um prazer estético de primeira ordem. \\ Walter Benjamin
}

No processo de reprodução do espaço urbano, a cultura se tornou uma estratégia significativa para alavancar a revalorização do Centro de São Paulo a partir da preservação do patrimônio que caracteriza uma representação do espaço, ao mesmo tempo em que produz também a identidade deste lugar. Neste caso, através daquilo que o atribui em estágio de “deterioração", o patrimônio (quando tombado e passível de ser revalorizado) torna-se o fator de ajuste que contribui na produção daquilo que tende à revalorização do espaço.

As transformações no patrimônio, para além da sua mudança física (quando reformado e/ou requalificado), caracteriza um processo de valorização que tende a se dissipar pelo espaço, conforme sua relação se encadeia com as transformações que ocorrem na escala do lugar. Ou seja, a reforma do patrimônio tende a atribuir ao seu entorno um novo valor de uso devido sua transformação que passa a ser assimilado de forma positiva pelo mercado imobiliário que se apropria desta realização. Para Scifoni (2015) este é o sentido que faz com que o patrimônio se ajuste tanto à realidade (marcada pelo próprio processo de revalorização) quanto ao tempo histórico atual (em que o patrimônio e suas representações culturais ganham novos significados para além daqueles que o afirmou na história). Ao se ajustar à realidade de revalorização do Centro de São Paulo, o patrimônio deixa de ser a estrutura histórica para ser uma estrutura que tende a auferir maior valor àquilo que está em seu entorno ou suas proximidades.

No caso do Centro de São Paulo, a venda desse novo valor de uso vem acompanhada de conteúdos do espaço que são marcados pela cultura, ou seja, por uma nova forma de consumo do espaço através das práticas culturais. Nestes termos, a cultura que serve de álibi para a realização de um novo valor de uso do espaço transforma-se em seu próprio negativo, se anula enquanto prática social-histórica quando realizada através da reprodução da metrópole na atualidade. Ao se anular enquanto próprio negativo - sob os fundamentos do valor de troca que a metamorfoseia no próprio negócio - a cultura passa a ser forma que coaduna com as estratégias vinculadas à revalorização do Centro de São Paulo. 
Essa relação de identidade entre lugar, cultura e morador não se realiza em todos os lugares do Centro de São Paulo, entretanto, para alguns moradores, isso já existe há algum tempo. Talvez este referencial de identidade já exista para os moradores que residem nas proximidades da Praça Roosevelt, marcada em sua proximidade por bares e teatros, na parte baixa da Rua Augusta (próxima ao distrito República); para os moradores do Largo do Arouche, da Praça da República, da Rua São Luís. O mesmo com alguns moradores da porção do Distrito do Bom Retiro, nos Bairros da Luz, Bom Retiro, Campos Elíseos que ficam próximo aos museus e a própria Estação da Luz. Da mesma forma que a cultura cria uma espécie de identidade com o morador, pelo fato deste ser um usador do lugar, o mesmo pode ocorrer quando o possível futuro usador for aquele que irá comprar uma propriedade em um bairro que se localiza num fragmento da cidade fortemente marcado pelo fator da cultura. Arantes (2001, p. 154) salienta esta dimensão como uma estetização da vida urbana que passa a ser encenada nesses novos (velhos) “espaços públicos” onde

\footnotetext{
a pretensa "apropriação simbólica" via encenação das diferenças, patrocinadas pelas políticas patrimoniais e culturais dos governos e outras entidades locais, tanto quanto o propósito de acertar contas com o esteticismo e a "frivolidade" das pósfilosofias contemporâneas, cujo "texto" pretende com involuntária razão "apenas" reproduzir esse mesmo processo indefinido de desdiferenciação cultural.
}

Por mais que este movimento ainda não se realize de forma significativa - e a relação da revalorização ainda é fortemente influenciada e se realiza em função da desvalorização - a tendência posta para o Centro de São Paulo, ao levarmos em conta a sinergia das políticas do Estado com o movimento de reprodução capitalista do espaço, é de uma segregação socioespacial quase que por completa do Centro, numa realidade em que essa desdiferenciação cultural tende a produzir o negativo da própria cultura, a partir do momento em que suas representações são apropriadas para a produção de um novo valor de uso que é posto à venda. A revalorização do Centro de São Paulo é também o momento de sua reprodução mimética, afinal, ao fazer parte de um processo de reprodução do espaço, tanto o patrimônio quanto a cultura atrelada a ele (ou também às práticas) são reproduzidas e deixam de lado sua unicidade primeira que a caracterizou como um patrimônio e/ou mesmo arte. Ao se reproduzir enquanto um objeto que tende a produzir um novo valor de uso (e nesse caso, ao próprio espaço), a cultura e o patrimônio se metamorfoseiam e tornam-se parte constitutiva do negócio inerente ao processo de urbanização. 
Tanto a cultura quanto a preservação do patrimônio garantem essas estratégias do Estado de maneira que essa produção tenha um consumo específico. Neste caso, não apenas o consumo imobiliário do lugar (reproduzido estrategicamente para esta realização) revela esta forma de consumo do espaço; há também outras formas de consumo do lugar como, por exemplo, através da atividade turística. O movimento das estratégias de revalorização do espaço em função do álibi cultural, também revela, por meio das políticas, a mudança de sentido e a centralidade do espaço neste momento da histórica.

Atualmente há o deslocamento das medidas de intervenção pontuais (Quadro 06), para as estratégias que se realizam através da delimitação de espaços específicos, caracterizados por alguma forma específica de representação que busca direcionar e controlar as práticas socioespaciais nestes perímetros. Desde a metade da década de 1980, quando as intervenções no âmbito dos equipamentos culturais adquiriu uma importância diferenciada, as intervenções deste âmbito no Centro de São Paulo foram caracterizadas por políticas pontuais, basicamente de reformas e articulações destes equipamentos com o lugar. Em função, talvez, das condições do momento, as estratégias consistiam em reformas de edifícios históricos, adaptações destes para a condição de museus, a adaptação também das estruturas da Estação Júlio Prestes para a construção da "Sala São Paulo" de concertos, entre outros. 
Quadro 6 - Políticas predominantemente pontuais de reformas de equipamentos culturais

\begin{tabular}{|c|c|c|c|c|c|c|}
\hline & Ano & Projeto & Estratégia & Programas & Espacialidade & Resultados \\
\hline 01 & 1984 & $\begin{array}{l}\text { Projeto "Luz } \\
\text { Cultural" }\end{array}$ & $\begin{array}{l}\text { Estratégia voltada para o uso dos } \\
\text { equipamentos culturais e estímulo } \\
\text { de outras atividades ligadas à } \\
\text { exploração do bairro pela atividade } \\
\text { econômica do turismo. }\end{array}$ & $\begin{array}{l}\text { Implantação de programas e roteiros turísticos } \\
\text { envolvendo todos equipamentos culturais do } \\
\text { estado, localizados nestes bairros; Mudança no } \\
\text { zoneamento do bairro com a parceria da } \\
\text { Prefeitura; Elaboração de um projeto de } \\
\text { divulgação; Intervenções para a recuperação de } \\
\text { alguns edifícios de interesse histórico; }\end{array}$ & $\begin{array}{l}\text { Composição do Território turístico: } \\
\text { Pinacoteca, Museu de Arte Sacra, } \\
\text { Convento da Luz, Liceu de Artes e } \\
\text { Ofícios, Igreja São Cristóvão, Conjunto } \\
\text { de Quartéis da Polícia Militar, Teatro } \\
\text { Franco e Teatro Taib. }\end{array}$ & \\
\hline 02 & $\begin{array}{c}1989- \\
1992\end{array}$ & $\begin{array}{l}\text { Programa } \\
\text { "Cidadania } \\
\text { Cultural" }\end{array}$ & $\begin{array}{l}\text { Efetuar a relação entre política } \\
\text { cultural e cultura política, buscando, } \\
\text { assim, criar uma espécie de } \\
\text { tradição. }\end{array}$ & $\begin{array}{l}\text { Implantado assimilava a cultura como direito dos } \\
\text { cidadãos e como trabalho de criação. O direito à } \\
\text { cultura era interpretado como direito à } \\
\text { informação; direito à fruição cultural; direito de } \\
\text { participar nas decisões relacionadas ao fazer } \\
\text { cultural; direito à produção cultural. }\end{array}$ & $\begin{array}{l}\text { Mesclou o que era produzido no centro } \\
\text { (o que não significa Centro da cidade de } \\
\text { São Paulo) e na periferia, produzindo } \\
\text { assim um campo de experimentações em } \\
\text { que a cultura popular vinha marcada } \\
\text { pelo cerne da resistência, através das } \\
\text { diferentes formas de intervenção } \\
\text { cultural capazes de modificar a } \\
\text { paisagem cultural da cidade. }\end{array}$ & $\begin{array}{l}\text { Funcionamento coletivo dos } \\
\text { departamentos com planejamentos e e } \\
\text { decisões coletivas integradas; } \\
\text { Implantação de Casas de Cultura nas } \\
\text { periferias e comunidades locais; } \\
\text { Regionalização e descentralização: da } \\
\text { ação cultural; Criado o Conselho de Arte } \\
\text { do Teatro Municipal; Conselho de } \\
\text { Preservação do Patrimônio Histórico e } \\
\text { Ambiental funcionando em coligação } \\
\text { com outros conselhos de política urbana; } \\
\text { Criação do Conselho Municipal de } \\
\text { Cultura; Totalizaram 120 intervenções } \\
\text { aumentando o patrimônio físico; No } \\
\text { Centro as obras foram feitas no Solar da } \\
\text { Marquesa, na Estação da Luz, no Teatro } \\
\text { Municipal. }\end{array}$ \\
\hline 03 & 1997 & $\begin{array}{l}\text { Projeto } \\
\text { "Operação } \\
\text { Centro" }\end{array}$ & $\begin{array}{l}\text { Adequação da Estação da Luz para } \\
\text { integrar o transporte metropolitano } \\
\text { por trem e metrô. Obras de } \\
\text { restauração e conservação do } \\
\text { patrimônio histórico-arquitetônico } \\
\text { com o objetivo de estimular a } \\
\text { dinâmica comercial da área central. }\end{array}$ & $\begin{array}{l}\text { Articulação dos espaços públicos em rede } \\
\text { (conjuntos interligados); Ampliação desses } \\
\text { espaços públicos com a incorporação de áreas } \\
\text { internas às quadras para a circulaçãa de } \\
\text { pedestres; } \\
\text { Criação de alternativas de circulação para } \\
\text { pedestres e veículos, integrando a apropriação } \\
\text { dos espaços ao uso cotidiano do Centro; }\end{array}$ & $\begin{array}{l}\text { Bairros Luz, Santa Ifigênia e Bom } \\
\text { Retiro, através de reformas de espaços } \\
\text { públicos }\end{array}$ & $\begin{array}{l}\text { Reforma e restauro no edifício da } \\
\text { Estação da Luz; Rebaixamento da calha } \\
\text { da Avenida Tiradentes; Adaptação da } \\
\text { Avenida Casper Líbero para um } \\
\text { boulevard de articulação entre a Luz e o } \\
\text { Vale do Anhangabaú; Requalificação do } \\
\text { Jardim da Luz e da Praça Cel. Fernando } \\
\text { Prestes (com edifícios do entorno); } \\
\text { Requalificação da Praça Princesa Isabel, } \\
\text { Praça Júlo Prestes e Largo Sagrado } \\
\text { Coração de Jesus; }\end{array}$ \\
\hline
\end{tabular}




\begin{tabular}{|c|c|c|c|c|c|c|}
\hline 04 & 1999 & $\begin{array}{l}\text { Polo Cultural } \\
\quad \text { Luz }\end{array}$ & $\begin{array}{l}\text { Atrelar a cultura às estratégias de } \\
\text { criação de polos de } \\
\text { desenvolvimento aproveitando a } \\
\text { concentração de equipamentos } \\
\text { culturais e um nó do transporte } \\
\text { coletivo ferroviário metropolitano. }\end{array}$ & $\begin{array}{l}\text { Preservação do patrimônio; } \\
\text { Implantação de equipamentos culturais e } \\
\text { monumentais (Sala São Paulo); } \\
\text { Restauração do sistema ferroviário. } \\
\text { Recursos: BID 50\%; Governo Federal } 30 \% \text {; } \\
\text { PMSP 20\%. }\end{array}$ & $\begin{array}{l}\text { Perímetro do Centro nas imediações do } \\
\text { bairro da Luz e Bom Retiro. }\end{array}$ & $\begin{array}{l}\text { Restauração da Pinacoteca do Estado; } \\
\text { Execução da Sala São Paulo de } \\
\text { Concertos; } \\
\text { Restauração da Estação da Luz; } \\
\text { Restauração do Mosteiro da Luz; } \\
\text { Melhorias na instalação do Museu de } \\
\text { Arte Sacra; } \\
\text { Recuperação do Jardim da Luz; } \\
\text { Reforma do antigo edifício do DEOPS; } \\
\text { Implantação do Museu de Energia. }\end{array}$ \\
\hline 05 & 2002 & $\begin{array}{c}\text { Programa } \\
\text { Monumenta Luz }\end{array}$ & $\begin{array}{l}\text { Aproveitando intervenções } \\
\text { anteriores, o programa tem como } \\
\text { referência a preservação do } \\
\text { patrimônio através de tombamentos } \\
\text { realizados. A proposta de } \\
\text { tombamentos se deu através do álibi } \\
\text { da importância histórica e cultural } \\
\text { do lugar para a cidade. }\end{array}$ & $\begin{array}{l}\text { Tombamentos: } \\
\text { Estação Júlio Prestes (edifício e praça); } \\
\text { Pinacoteca do Estado; Esculturas do Jardim da } \\
\text { Luz; Pontos de bondes e coretos. } \\
\text { Recursos do BID através do Governo Federal }\end{array}$ & $\begin{array}{l}\text { Área de intervenção e recuperação } \\
\text { patrimonial: } \\
\text { Conjunto Histórico Área da Luz; } \\
\text { fragmentos do bairro do Bom Retiro, } \\
\text { Santa Ifigênia e Campos Elíseos. } \\
\text { Lugar estratégico dotado de } \\
\text { infraestrutura de transporte } \\
\text { metropolitano e de imóveis degradados } \\
\text { com possibilidades de revalorização } \\
\text { futura. }\end{array}$ & $\begin{array}{l}\text { Previsão de valorização imobiliária } \\
\text { através de requalificação estética do } \\
\text { bairro da Luz e seu entorno; Incentivo } \\
\text { ao desenvolvimento do comércio; na } \\
\text { revitalização imobiliária através das } \\
\text { possibilidades do Centro transformar-se } \\
\text { em função da estratégia da cultura; } \\
\text { Incentivo ao turismo cultural e de } \\
\text { compras. }\end{array}$ \\
\hline 06 & 2010 & $\begin{array}{l}\text { Complexo } \\
\text { Cultural Luz }\end{array}$ & $\begin{array}{l}\text { Proposta: ser um dos mais } \\
\text { importantes centros destinados às } \\
\text { artes do espetáculo do Brasil. O } \\
\text { edifício abrigará diferentes } \\
\text { equipamentos culturais para a } \\
\text { encenação de musicais, óperas, } \\
\text { shows de música popular e outras } \\
\text { manifestações artísticas. O Centro } \\
\text { Cultural Luz consolidará o maior } \\
\text { polo cultural da América Latina. }\end{array}$ & $\begin{array}{l}\text {-Um teatro principal com capacidade para } 1750 \\
\text { assentos que será dedicado principalmente à } \\
\text { dança e à òpera } \\
\text { - A nova sede da Escola de Música do Estado de } \\
\text { São Paulo - Tom Jobim, para } 2000 \text { alunos } \\
\text { - Uma sala de recitais com capacidade para } 500 \\
\text { assentos } \\
\text { - A nova sede da São Paulo Companhia de } \\
\text { Dança } \\
\text { - Um teatro experimental flexível com } \\
\text { capacidade para } 400 \text { assentos, que poderá será } \\
\text { dedicado a todas às artes do espetáculo } \\
\text { - Estacionamento para } 850 \text { veículos } \\
\text { - Café e restaurante } \\
\text { - Uma escola de dança } \\
\text { - Salas de ensaio para companhias residentes } \\
\text { - Biblioteca } \\
\text { - Estúdio de música } \\
\text { - Área verde }\end{array}$ & $\begin{array}{l}\text { Local: Praça Júlio Prestes, mas leva-se } \\
\text { em consideração o eixo de } \\
\text { equipamentos culturais do entorno. }\end{array}$ & $\begin{array}{l}\text { Paralisado pelo Governo do Estado de } \\
\text { São Paulo. } \\
\text { Gastos R\$ } 53 \text { milhões com arquitetos e } \\
\text { R } \$ 65 \text { milhões com desapropriações. } \\
\text { Previsão se fosse concluído: } \mathrm{R} \$ 600 \\
\text { milhões. }\end{array}$ \\
\hline
\end{tabular}


Assim a revalorização do Centro de São Paulo é portadora de uma estética específica, estrategicamente ligada à cultura, a sua possibilidade de venda. A cultura, transformada em negócio através da produção do espaço, passa a ser uma forma tomada pelos imperativos do capital nos fundamentos da realização do valor de troca, cuja finalidade é a obtenção de lucros. Assim como novas indústrias surgem na atualidade (como a indústria imobiliária, por exemplo), a indústria cultural adquire potência quando concebida através da reprodução da cidade. A reprodução dos lugares (sejam enquanto simulacros, ou mesmo através da produção estratégica das identidades) imprime significados diferenciados quando considerados a partir da cultura. Bairros com significativas relações de identidade com a cultura, ruas de teatros, eixos culturais são fenômenos que, atualmente, fundamentam o processo de reprodução capitalista da metrópole paulista (e/ou até mesmo em outras cidades, independente do seu tamanho ou porte). A indústria cultural se realiza e se reproduz em sinergia com a indústria do imobiliário, e estas duas, por sua vez, somente em função das condições postas pelo Estado.

$\mathrm{Na}$ reprodução da metrópole os lugares se redefinem conforme os interesses econômicos que movem as transformações e, assim, no Centro, sua revalorização calcada na cultura é também uma forma de reproduzi-lo por meio de novos conteúdos, identidades e representações do espaço. As metamorfoses do patrimônio não são realizadas pelas relações diretas de compra e venda ${ }^{207}$, entretanto, ao considerar que tal processo ocorre de maneira indireta (nas cartilhas da agência multilateral de fomento a proposta de reforma e/ou revitalização dos patrimônios também circunscrevem à sua valorização ${ }^{208}$ ), veremos que tal metamorfose - que vai para além da sua transformação exterior e/ou estética - é também uma metamorfose de sua função. Nesse caso, um duplo movimento: 1) metamorfose de patrimônio histórico-arquitetônico para patrimônio cultural (mobilizando no espaço uma estrutura arquitetônica burguesa que foi produzida em um determinado tempo histórico e tornando-a cultura $\left.^{209}\right)$; 2) a metamorfose de uma estrutura desvalorizada (deteriorada) para uma estrutura que impõe e atribui valor (nesse caso, ao espaço). Suas metamorfoses na atualidade tem como consequência um processo específico de valorização, já que o mesmo passa a ser objeto

\footnotetext{
${ }^{207}$ Nesta situação faço um paralelo com a metamorfose das mercadorias, posta por Marx (2013). Nela, o autor salienta que a metamorfose das mercadorias se realiza através das transações entre os portadores de mercadorias, por meio das relações de compra, venda e troca da mercadoria por dinheiro.

${ }^{208}$ Para Rojas $(2001$, p. 18), estimular o retorno aos centros históricos de famílias de renda média e alta que os abandonaram a algumas décadas, envolve os efeitos negativos que a revitalização tem sobre as famílias de baixa renda que o ocupam na atualidade. $\mathrm{O}$ incremento do valor do solo que experimentam os centros históricos no processo de conservação e revitalização, reflete os benefícios obtidos pelas atividades econômicas e famílias que se localizam nele.

${ }^{209}$ Aliás, do ponto de vista histórico é uma estrutura que somente conta a história das burguesia e suas representações no espaço.
} 
também do turismo, afinal, além da revalorização do Centro de São Paulo, há a valorização turística do patrimônio ${ }^{210}$ que possibilita a manipulação simbólica de um universo de considerável importância para a sociedade burguesa.

No Centro de São Paulo há lugares onde concentram-se diversas estruturas arquitetônicas tombadas que, no movimento de revalorização do espaço, adquirem novos conteúdos que contribuem com este processo. O Bairro da Luz é onde há uma concentração significativa desses equipamentos, a ponto do Estado promover algumas políticas ${ }^{211}$ que o considera como um "eixo de equipamentos culturais". Este eixo localiza-se na divisa dos bairros $^{212}$ que circundam os distritos Sé e República do centro histórico e centro expandido. Estratégico à revalorização do Centro, o eixo de equipamentos culturais no Bairro da Luz é dotado de estruturas que passaram por um processo massivo de tombamento há treze anos, através do Programa Monumenta Luz, financiado pelo BID (Banco Interamericano de Desenvolvimento).

Mapa 4 - Território e zonas de paisagem e preservação cultural

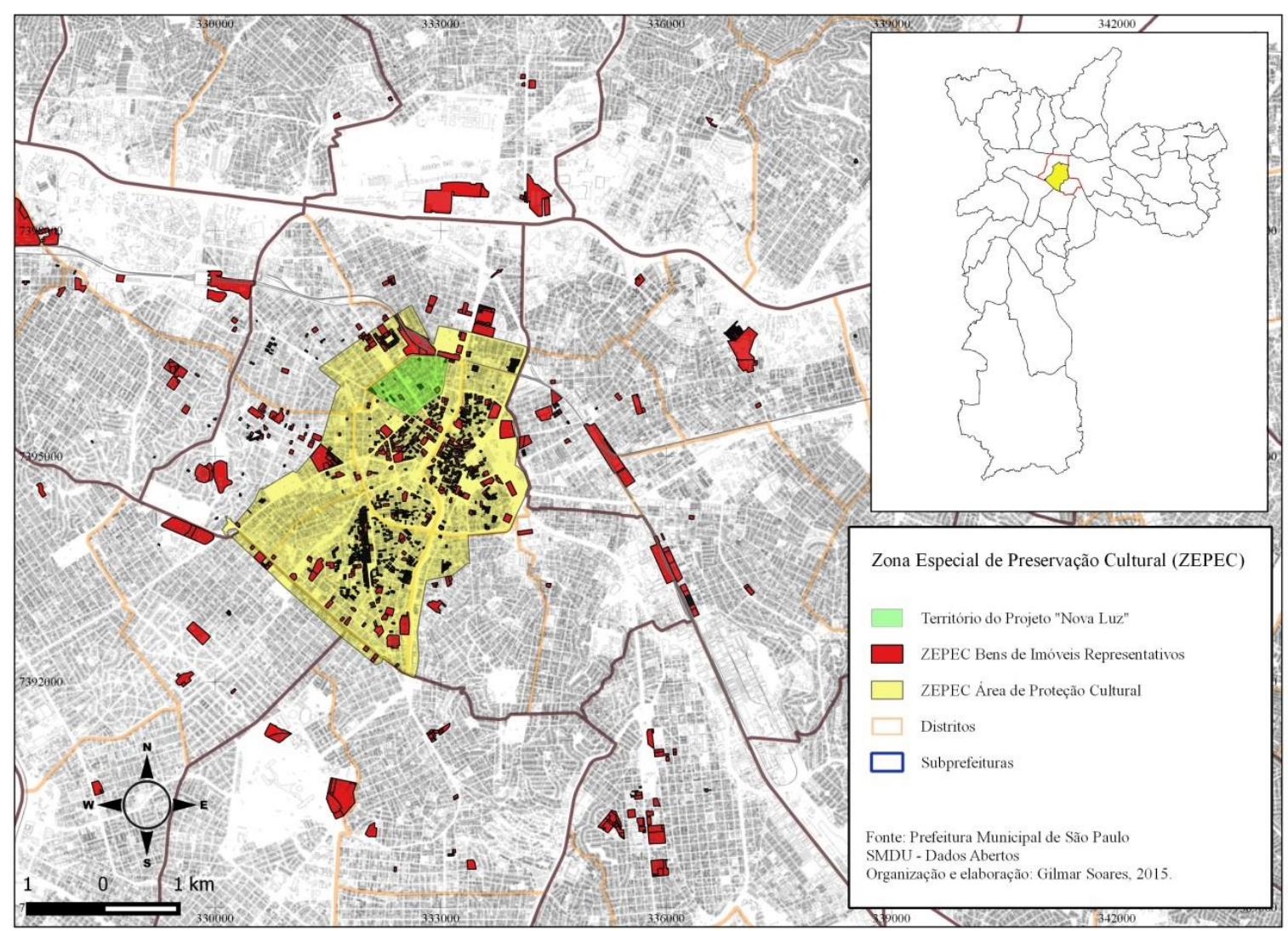

\footnotetext{
${ }^{210}$ Rodrigues, 2003, p. 19.

${ }^{211}$ Caso do Complexo Cultural Luz, atualmente paralisado pelo Governo do Estado de São Paulo.

${ }^{212}$ São eles o Bom Retiro, o Campos Elíseos e o próprio bairro da Luz.
} 
Ocorre que boa parte dos imóveis tombados como "Bens Imóveis Representativos" (BIR) estão localizados nos distritos Sé e República, além de uma quantia significativa no distrito da Bela Vista (nos bairros Bela Vista e Bixiga). O Centro de São Paulo (Centro Antigo e Centro República), adensado e implodido pelos conteúdos do processo de urbanização, fica praticamente "congelado" em função destes imóveis e/ou áreas tombadas. Essas políticas de tombamento de bens culturais delimitam territórios estratégicos onde a manutenção da paisagem é, ao mesmo tempo, sua estabilização no espaço e a manutenção da sua continuidade no tempo. A delimitação estratégica desses territórios coaduna com a proposta explícita do Estado delimitar apenas os fragmentos do espaço da cidade que também serão vendidos aos turistas. Por exemplo, além do Centro de São Paulo, há um eixo no bairro do Bixiga composto pela Rua Treze de Maio (conhecida pela festa e representações do espaço com a cultura italiana) e arredores que também torna-se um fragmento estratégico, já que está próximo da Avenida Paulista e do Centro de São Paulo.

O beneficiamento destas políticas segue direto para o mercado imobiliário e sua indústria que aufere lucros significativos com o processo de urbanização da metrópole. $\mathrm{O}$ patrimônio, nessas áreas onde ocorrem (ou ainda ocorrerão) o processo de valorização, cumpre de maneira eficiente seu papel, pois, se por um lado ele deixa para a posteridade uma arquitetura e uma história da consolidação da sociedade burguesa na cidade de São Paulo, por outro, ele se metamorfoseia numa estrutura arquitetônica que atribui um novo valor de uso (ou mesmo reforça o antigo valor sob alguns significados novos) ao lugar.

O "eixo de equipamentos culturais" no Bairro da Luz pode nos dar pistas de como se desenrolam essas estratégias, quando pensamos nas dinâmicas de reprodução do espaço nos bairros e distritos que ficam no entorno do Centro. Conforme veremos adiante, os bairros do entorno ao Centro (distritos Sé e República) passam por uma dinâmica de reprodução do espaço cujos conteúdos do processo ligado à dinâmica imobiliária são caracterizados pela identidade do Centro de São Paulo. Muitos dos empreendimentos que estão sendo vendidos nos distritos do entorno, principalmente Brás e Bom Retiro, passam por um momento em que a dinâmica do mercado imobiliário encontrou nestes lugares, espaço em potencial para o desenvolvimento de novos empreendimentos. Ao mesmo tempo, nas proximidades do Centro Histórico e Centro expandido (República), empreendimentos de menor porte são lançados com vistas ao novo perfil de comprador. Outra estratégia do mercado imobiliário vem ser a prática do retrofit total que tende a reformar por completo toda estrutura de edifícios antigos e amplos. 
O patrimônio arquitetônico tornado patrimônio cultural revela a estratégia do espaço que se acopla com a estratégia do capital para o Centro e seu entorno e, assim, revela, atualmente, algumas facetas do processo de revalorização do Centro de São Paulo. No Centro de São Paulo, o patrimônio e sua valorização vêm a reboque da metamorfose dos lugares em que o consumo estético fomenta também formas de consumir turisticamente o espaço. $\mathrm{O}$ patrimônio, neste caso, contribui com o desenvolvimento do turismo também ligado às visitas às estruturas arquitetônicas em que uma estética urbana passa a girar também em torno destas. Lipovetsky e Serroy (2015) chamam a atenção, nestes casos, para uma estetização museal da cidade, ou seja, a desintegração total da vida dos bairros em função da relegação das comadas populares destes espaços museificados. No caso do Centro de São Paulo, o patrimônio arquitetônico contribui com a produção de uma estética (ligada à cultura e aos negócios que derivam desta esfera) que tem como um dos objetivos fazer com que uma classe média, ou pequeno-burguesia conforme estamos asseverando ao longo desta dissertação, seja o perfil de morador predominante deste fragmento da metrópole. A vida e as formas de sociabilidade tendem a se realizar em função daquilo que foi promovido anteriormente, talvez, até mesmo promovendo aquilo que Lipovetsky e Serroy chamaram de cidade-clichê.

\subsubsection{Estratégia da cultura, economia criativa e prática econômica do turismo: a estética do espaço mercadoria}

A produção política do espaço cultural é um momento da produção estatista do espaço que se realiza através das estratégias que são postas para a reversão da desvalorização do Centro de São Paulo. Ao produzir politicamente um espaço, o Estado produz também um espaço que passa a ser produtor, ou seja, um espaço que direciona as formas de produção ao mesmo tempo em que determina a sua própria produção.

As estratégias desta produção política do espaço, a cargo do Estado, revelam em sua diversidade os interesses de classes que conduzem a reprodução do Centro de São Paulo. Sejam estas estratégias pelo álibi da cultura, sejam elas através do álibi ambiental, ou mesmo pelo álibi do desenvolvimento econômico ${ }^{213}$, o que está posto é a reversão do processo de desvalorização por meio de um processo de revalorização. O mecanismo, por excelência, para a realização deste movimento é o processo de produção do espaço que amplia significativamente a relação entre produção e consumo. Nesta ampliação o espaço se torna

\footnotetext{
${ }^{213}$ Este tipo de desenvolvimento que é sempre imputado pelas agências de fomento que investem quantias significativas para a reprodução do espaço urbano das cidades, como é o caso do BID.
} 
condição, meio e produto que tem no Estado (e também em seus aparelhos) o ente que supõem e organiza o espaço conforme suas exigências ${ }^{214}$.

Enfim, o que vale salientar é que, conforme assevera Lefebvre (1976), o espaço produzido (pelo Estado) é também o espaço produtor, portanto, um instrumento ativo, em movimento que tende a se diferenciar do seu conteúdo, exatamente para poder transformá-lo. No caso da produção política de um espaço cultural, a lógica que fragmenta (recorta, separa, diferencia, classifica e delimita territórios de intervenção) é a mesma que se realiza a partir de conteúdos homogeneizantes. A cultura desenvolve com eficiência esse papel em que uma função específica (de revalorizar) foi posta em teste em algumas cidades do mundo e o principal exemplo está no caso de Barcelona ${ }^{215}$.

Cultura, estética, arte e criação humana entram em xeque quando postos diante do momento da produção do espaço, a ponto de pensarmos se uma possível crise destas dimensões não ganham conotações significativas diante da crise urbana, esta, por sua vez, posta enquanto crise da reprodução do espaço ${ }^{216}$. Nessa produção política do espaço cultural, a produção da mercadoria arte ganha significados atuais e potência para a reprodução do Centro de São Paulo, agora, sob novas representações e novos conteúdos.

Rodrigues (2003) denota uma amplitude à noção de patrimônio cultural, pelo fato de que esta - além dos bens culturais e do patrimônio histórico-arquitetônico - envolve ainda a noção de patrimônio ambiental. A consideração da autora tem um significado importante para esta análise do processo de revalorização do Centro de São Paulo, pois, sua noção de ambiente tem como referência uma concepção de que este é o produto da ação dos homens e esta, por sua vez, resulta da cultura. Ou seja, para Marly Rodrigues, aquilo que está posto como "ambiente" é interpretado e concebido aqui como o momento da produção do espaço.

\footnotetext{
${ }^{214}$ Lefebvre, 2000, p. 102.

215 Arantes $(2012 ; 2012 \mathrm{a})$, assim como outros autores, destacam este papel de Barcelona e seu modelo de planejamento que é exportado atualmente para o mundo todo, principalmente para a América Latina.

${ }^{216}$ A título de explicação, a partir do momento em que o curso da narrativa histórica (nos termos hegelianos) aparenta estar num movimento perpétuo de presente, em que as formas de negatividade não imputam mais as potências transformadoras da sociedade, o debate que foi posto (sobre o "Fim da História" e "Fim da Arte") parece ganhar significados reais quando analisados sob o prisma da produção do espaço. Estas crises postas, tanto por uma, talvez, possível dimensão epistêmica (crise do "Fim da História") quanto por uma dimensão artística (crise do "Fim da Arte"), no sentido em que assevera Jameson (2006, p. 127) se realizam por conotações ideológicas que ganham potência através da produção do espaço. Conforme estamos observando, no ato da produção política do espaço cultural, o processo de tombamento "congela" no tempo as estruturas espaciais que consolidou a sociedade burguesa na cidade, ao mesmo tempo em que atribui a esta os conteúdos artísticos e culturais, atribuídos por uma estética específica que ganha significado no momento do consumo; ainda mais quando relevamos o fato do consumo do espaço. No momento da reprodução do espaço, a estética ganha novo sentido atribuído ao consumo, o tempo efêmero da sociabilidade burguesa ganha novas potências para sua continuidade, da mesma maneira que a arte torna-se apenas uma representação de algo que já ocorreu e, com isso, tende a perder sua potência crítica. No momento da reprodução do espaço, a homogeneização somente se realiza para anular toda e qualquer diferença que venha a surgir, por meio da dominação e opressão do Estado.
} 
No processo de reprodução do Centro de São Paulo, tanto os bens culturais quanto os patrimônios histórico-arquitetônicos que compõem este fragmento da metrópole, são apropriados sob novas condições que se realizam enquanto formas específicas de sua reprodução. Nestes termos, o patrimônio cultural (que envolve agora o próprio espaço), potencializado pela produção do espaço, adquire sentidos específicos na revalorização do Centro, ao atribuir ao espaço uma nova representação que se realiza por meio da produção de um novo valor de uso.

A estratégia cultural atravessa o processo de revalorização do Centro de São Paulo e, para além da indústria do imobiliário, outras formas de indústria também acabam de mobilizando neste processo como a indústria da cultura e a indústria do turismo. Cultura, turismo e imobiliário tornam-se indústrias na atualidade somente em função da potência do processo de produção do espaço, ampliado da noção de espaço social.

A produção do patrimônio cultural no Centro de São Paulo coaduna com algumas formas específicas e determinadas de consumo do espaço, tanto pelos equipamentos de cultura quanto pelos lugares comerciais e já conhecidos do Centro que atraem turistas há anos, como é o caso do Mercado Municipal, a Rua 25 de Março, o bairro do Brás e o Bairro do Bom Retiro (estes dois últimos, conhecidos pela concentração de lojas de comércio de roupas). Assim, se o processo de valorização do patrimônio corresponde a um momento de revalorização do Centro de São Paulo, a valorização turística é outra dimensão do processo de reprodução que se realiza também por meio da ampliação deste leque de possibilidades inscritas na prática de consumo do espaço.

Patrimônio cultural, turismo e reprodução do Centro são estratégias de revalorização que se realizam em plena sinergia enquanto momento da reprodução capitalista da metrópole. Por mais que sejam formas distintas de turismo ${ }^{217}$, a estratégia do Estado é sempre no sentido de aproximá-las por meio de representações ideologizadas do espaço; no caso dos bairros do Brás, Pari e Canindé (e que podemos considerar também o Bom Retiro) concebidos enquanto um Polo de Comércio e Desenvolvimento de Moda ${ }^{218}$. Naquilo que está posto como setor central, de acordo com a lógica do Plano Diretor Estratégico de 2014, o turismo para o Centro de São Paulo é marcado por atividades econômicas e culturais significativas, todas reunidas no distrito Sé e uma parte do distrito Mooca.

Ao situar o turismo no movimento de produção/reprodução do espaço e comprovando sua dupla qualidade econômica e social, (SOARES, 2015, p. 242) assinala que "o turismo é

\footnotetext{
${ }^{217}$ Nestes casos, turismo de compras, turismo cultural e de lazer, turismo de negócios etc.

${ }^{218}$ Lei n $^{\circ} 16.050$ de 31 de Julho de 2014, Art. 180 sobre as centralidades polares e lineares.
} 
um elemento do processo de reprodução conduzido pelos projetos governamentais que 'preparam' a cidade para o consumo da experiência urbana e para a instalação e ou valorização dos negócios que a ela associam”. Ou seja, a dimensão econômica e social do turismo, conforme as posições do autor, entram em sinergia (e somente se realizam) em função da dimensão política imposta pelo Estado ao produzir o espaço com todas as condições políticas de realização de uma atividade econômica. Todas as estratégias e planos que atravessam o Centro de São Paulo revelam as políticas confluídas para um objetivo em comum: o de revalorização deste fragmento da metrópole. A dimensão classista ligada à concepção turística do Centro de São Paulo também deve ser atrelada a este processo de revalorização, afinal, além das estratégias do Estado para fomentar esta atividade econômica no Centro, podem ser também vislumbrados, através das propostas explícitas da Associação Viva o Centro (AVC) em diversas de suas publicações, os incentivos à reprodução do espaço com seus conteúdos também voltados para o turismo, o que exige necessariamente um processo de (des)proletarização do Centro de São Paulo ${ }^{219}$.

A reprodução do Centro também passa a ser marcada por outro fator atual que aponta como que as tendências surgem enquanto estratégias para a revalorização do espaço. Neste caso, a então chamada economia criativa compõe o conjunto dessas três dimensões que compõem uma estética especifica que direciona o processo de reprodução-revalorização do espaço no Centro de São Paulo e seus distritos do entorno. Por ser uma estratégia espacial que se realiza a partir da criação de polos de centralidade, a economia criativa, enquanto polo de ação, se realiza em função da consolidação da área (portanto, de um espaço delimitado estrategicamente) como polo criativo, cultural, gastronômico, de lazer, de divertimento e de entretenimento $^{220}$. Conforme assegura a Prefeitura Municipal de São Paulo

os Polos de Economia Criativa - PEC são territórios destinados ao fomento e desenvolvimento de atividades econômicas que compõem a economia criativa, entendida como o ciclo de criação, produção e distribuição de bens e serviços tangíveis ou intangíveis que utilizam a criatividade, a habilidade e o talento de

\footnotetext{
${ }^{219}$ Os documentos e estudos emitidos pela PMSP apontam e fundamentam os discursos que atrelam o processo de desvalorização do Centro de São Paulo e seu entorno, ao processo de intensificação da sua ocupação proletária. Ao discorrer sobre aquilo que chama de decadência e ressurgimento, o (TURISMO NO CENTRO, 2008, p. 17) enfatiza que o Centro, especificamente, atravessa uma fase visível de decadência a qual perdura até a virada de século. Com algumas exceções, as residências nos distritos Sé, República e Bom Retiro são ocupadas por famílias carentes, com pouco acesso a serviços básicos e ao mercado consumidor. Proliferam-se os cortiços e moradias ilegais. Escritórios e empresas se transferem para outras áreas da cidade, como a Avenida Paulista. Crescem os problemas de segurança, comércio informal e consumo de drogas. À noite, raros são os usos sociais positivos. No entanto, apesar do desgaste na utilização do espaço público, o Centro continua com a função de importante eixo econômico da cidade. Meus grifos.

${ }^{220}$ Artigo 181 da Lei n ${ }^{\circ} 16.050$, de 31 de Julho de 2014.
} 
indivíduos ou grupos como insumos primários, sendo composta por atividades econômicas baseadas no conhecimento e capazes de produzir riqueza, gerar emprego e distribuir renda ${ }^{221}$.

$\mathrm{Na}$ esteira das tentativas de novas estratégias políticas para a revalorização do Centro de São Paulo, o primeiro polo de economia criativa criado na cidade de São Paulo localiza-se nos distritos Sé e República, estes, intitulados também como Distritos Criativos ${ }^{222}$.

Lima (2012, p. 31) assegura que estes polos criativos se realizam a partir do espaço como um ponto agregador, levando em conta as estratégias de identificação e atuação. Dois escopos de abrangência espacial caracterizam estes polos: 1) a abrangência geográfica/territorial, através da delimitação de territórios específicos de intervenção, produção da identidade e atuação; e 2) abrangência por rede de atuação, quando estas atuações (e/ou ações) se apropriam das redes e fluxos que atravessam o espaço.

A cultura torna-se uma estratégia política atual para a revalorização do Centro de São Paulo e seu entorno limítrofe, pois, portadora de uma estética específica - intimamente ligada aos conteúdos do espaço-mercadoria - foi somente no momento em que as condições e o desenvolvimento das forças produtivas permitiram a mundialidade do espaço, e que os espaços tidos como desvalorizados, por sua vez, adquiriram a possibilidade de entrar novamente no circuito da produção. Conforme assegura Carlos (1996), assim que ocorreu este movimento na história, em que o processo de produção do espaço tornou-se estratégico e político, novas indústrias (como a da cultura, do turismo e do lazer) surgiram e influenciaram significativamente no processo de reprodução.

Tanto no capitalismo quanto no direcionamento das políticas para a cidade de São Paulo, a cultura torna-se uma noção que se amplia conforme as necessidades que surgem. A título de exemplo, a raridade de algum bem faz dele algo único e não-reprodutível de maneira que este, por estas mesmas condições, seja algo portador de valor. Ao tombar como patrimônio tanto os bens imobiliários quanto a própria paisagem do Centro ${ }^{223}$ (ver mapa 04), o Estado se encarrega de delimitar estrategicamente o espaço, produzindo-o politicamente por meio de tombamento dos monumentos históricos. Estes, ao serem tombados, tornam-se bens únicos e não-reproduzíveis, se enquadrando na condição de bens semipúblicos que, necessariamente, geram efeitos externos, portanto, espaciais. Ao terem seu valor propalado no espaço, além da revalorização de tudo que está ao seu redor (inclusive o lugar) os efeitos

\footnotetext{
${ }^{221}$ Artigo 182 da Lei n ${ }^{\circ} 16.050$, de 31 de Julho de 2014.

${ }^{222} \S 1^{\circ}$ do Artigo 182 da Lei $n^{\circ} 16.050$, de 31 de Julho de 2014.

${ }^{223}$ Por meio das Zonas Especiais de Preservação Cultural - Bens de Imóveis Representativos (ZEPEC - BIR), ou então por meio das Zonas Especiais de Preservação Cultural - Área de Proteção Cultural (ZEPEC - APC).
} 
resultantes são aqueles turísticos, aqueles que veiculam também os valores coletivos e contribuem para forjar a identidade do lugar e, ao mesmo tempo, redefinir as representações do espaço.

Acerca da valorização auferida a partir do patrimônio tombado e consumido como mercadoria, (SCIFONI, 2015, p. 131) nos alerta que "este modelo que fetichiza os objetos da cultura para explorar seus valores mercadológicos consequentemente também destrói a essência do patrimônio, uma vez que desvirtua o seu significado simbólico e social". Para a realização das estratégias da reprodução do espaço, a cultura se amplia conforme as necessidades postas pelo limite do lugar e, ao mesmo tempo, como necessidade de produção de novas frentes de acumulação. Ao destruir a essência do patrimônio, conforme asseverou Scifone anteriormente, a cultura se encarrega, por meio desta apropriação capitalista do bem histórico, de expandir seus limites integrando o patrimônio às necessidades de mercado e consumido através da sua inclusão na vida cotidiana, já que torna-se objeto das formas de lazer por meio do consumo do espaço.

Por meio da produção política de novas representações, o Centro e seu entorno, tendem, gradativamente, a serem consumidos como o espaço qual é atrelado as representações da cultura e da imagem; e a paisagem tombada, que até então constituía parte do "impasse" para sua revalorização, torna-se o objeto a favor. Ao invés de destruir as antigas estruturas e revalorizar o espaço a partir das novas, a estratégia da cultura consiste numa espécie de sobrevida às tentativas de revalorização do Centro que, até então, não surtiram o efeito esperado. De entrave para a reprodução do Centro para solução, o espaço superedificado, quando atravessado por uma estética específica em sí (aquela dos conteúdos "retrô") tende a se constituir como uma possibilidade de revalorização e atração de moradores de classe média e média alta para o Centro.

O processo que ocorre no Centro é similar aquilo que Jameson (2006, p.240) considerou como a transformação dialética dos efeitos do valor de troca e da equivalência monetária, ou seja, quando a equivalência monetária provoca um novo interesse pela propriedade dos objetos. Para o autor, essa dialética dos efeitos do valor de troca corresponde a um novo estágio em que a equivalência resulta da retração das antigas noções de substância estável, com as suas identificações unificadoras. Ou seja, levando em conta que durante um longo tempo o Centro de São Paulo tornou-se um fragmento da metrópole que passou por um processo de desvalorização, isso somente ocorreu porque, necessariamente, outros fragmentos passavam pelo processo oposto de maneira que não poderiam haver concomitantemente outros espaços em mesmo estágio. 
A valorização diferenciada dos lugares, em função da centralidade constituída enquanto nova capacidade de concentração, faz com que o espaço-mercadoria produza uma mobilização frenética, levando à desvalorização (e/ou deterioração) de antigos lugares na contrapartida das possibilidades de maior acumulação com os novos. Porém, do ponto de vista do capital, a desvalorização torna-se uma possibilidade de negócio e, assim, conforme há alguma retração ou necessidade de produção de nova mercadoria espacial ${ }^{224}$ para ser vendida, ocorrem os momentos de retração das noções daquelas mercadorias espaciais que em momentos anteriores eram estáveis.

No caso do Centro de São Paulo e sua estratégia atual de revalorização, as identidades e representações do espaço cumprem com um papel unificador que se realiza por meio das redefinições e ampliações espaciais das estratégias de intervenção. Por meio de seu processo de revalorização, no Centro, todos os objetos (inclusive as pessoas que compõem a paisagem) tornam se equivalentes como mercadorias em que as diferenças passam a ser niveladas pelo dinheiro; cor, forma, volumes, quantidade, qualidade, movimentos etc. de tudo aquilo que caracteriza o espaço passa a ter "vida independente" pelo fato do espaço socialmente produzido ter se metamorfoseado em força produtiva. Ou seja, por meio da cultura, agora que se realiza sob a lógica do negócio, a produção de um novo valor tem como referencial os próprios elementos que são constitutivos do Centro de São Paulo e suas representações. A partir do momento em que estes são apropriados e fomentam um novo valor de uso para o espaço através da própria cultura, há um desenvolvimento que faz com que estas condições inerentes ao Centro de São Paulo o metamorfoseie, também, em força produtiva. O valor anterior, mesmo que o espaço esteja em condição de desvalorização, é conservado em função das formas de uso que se tornam, praticamente, predominantes. Assim, com a produção de um novo valor de uso, há uma nova forma de explorar essas condições que são espaciais através de novas propriedades que derivam do Centro de São Paulo e seus arredores. Somente quando este fragmento da metrópole torna-se uma condição para a produção baseada no capital lembrando que a cultura passa a ser um dos componentes que fomenta tal produção - a ponto das estruturas espaciais se tornarem capital fixo. Assim, o Centro e até mesmo a metrópole podem ser interpretados enquanto força produtiva, afinal, estes fomentam novas formas de produção e acumulação de capital e, neste caso, principalmente através da reprodução do Centro de São Paulo a partir da produção de um novo valor de uso que poderá ser posto na condição de troca.

\footnotetext{
${ }^{224}$ Neste caso, compreendida através das próprias identidades dos lugares e representações socialmente e historicamente construídas do espaço.
} 


\section{CONSIDERAÇõES FINAIS}

A problematização gira em torno das estratégias do Estado que, por meio de uma produção instrumental e política do espaço, contribui com a acentuação da segregação socioespacial e com a continuidade da reprodução das relações sociais de produção, a partir do momento em que sua forma política tem como referencial a própria forma mercadoria que se potencializa ao se reproduzir por meio da reprodução do espaço.

O espaço social e historicamente produzido do Centro de São Paulo pode ser considerado atualmente enquanto resultado do desenvolvimento das forças produtivas e das relações de produção na metrópole ${ }^{225}$. O Centro, atualmente e em função da sua reprodução, torna-se o espaço produtivo, objeto de uma prática instrumental e abstrata que se realiza através das políticas e estratégias do Estado. Estas, ligadas a uma relação de produção que visa a reprodução, permite considerá-lo enquanto uma das dimensões da força produtiva que transforma e reproduz a metrópole e o urbano. Sua revalorização é uma forma de incrementar cada vez mais massas de valores de uso, portanto, novos valores de uso, abstratamente, estrategicamente e politicamente produzidos para efetivar a forma-mercadoria; ao mesmo tempo em que sua reprodução o revela enquanto condição e meio para a realização do lucro e da acumulação.

A reprodução do Centro de São Paulo expressa significativamente a ampliação da noção de produção do espaço, afinal: a) neste processo a cidade torna-se força produtiva; b) o Centro (em função de seus lugares e toda sua estrutura e infraestrutura) torna-se capital fixo; c) o processo de revalorização do Centro é caracterizado pela "confecção" de um produto específico, marcado pelo álibi da cultura, ou mesmo pela cultura já como negócio; d) visa reverter à contradição da raridade do espaço, expandindo a reprodução como forma de desobstruir tanto as fronteiras entre os bairros quanto as fronteiras dentro dos bairros; e) é marcada pelo interesse e iniciativa de classes sociais opostas que disputam o espaço, principalmente no campo político (marcado pelas ideologias e representações de classes); f) conforme esta polarização entre as classes, o Centro expressa possibilidades e tendências, ou descontinuidades e continuidades.

\footnotetext{
${ }^{225}$ Da sua constituição decorrente do período da economia cafeeira que produziu suntuosos monumentos, passando pelo período da industrialização que o verticalizou, adensou e concentrou os conteúdos da urbanização; e chegando na atualidade do financeiro e terciário avançado que, ao valorizarem outros lugares da metrópole, devido a concentração de novas estruturas, ocasionou indiretamente a sua desvalorização. Contudo, o Centro ainda é o portador de infraestruturas e estruturas urbanas significativas, que não se encontram na maioria dos lugares da metrópole.
} 
Dessa maneira, o processo de reprodução do Centro de São Paulo constitui, atualmente, aquilo que revela ser duas frentes de intervenção. Nestes, as intervenções no espaço público e os incentivos oferecidos pela Operação Urbana Centro (no tocante às reformas das estruturas arquitetônicas e urbanísticas) apontam uma tendência de "reforma" destas reformas, a prática do retrofit total tende a redefinir, ou mesmo dar uma sobrevida, aos negócios de imóveis nos distritos Sé e República. Além disso, os poucos e pequenos terrenos negociáveis determinam a dinâmica dos empreendimentos que vem sendo produzidos e lançados no Centro através da Operação Urbana. Contudo, há aquilo que consideramos ser o fator preponderante, ainda mais porque há a relação sinérgica entre Estado e capital no movimento de reprodução do Centro e da metrópole: a expansão da fronteira imobiliária ligada ao Centro e o processo de destituição das fronteiras nestes bairros arredores. Esta possibilidade amplia ainda mais o Centro (ou o fragmento da metrópole que corresponde ao seu Centro) enquanto uma tendência de uma nova fronteira de acumulação.

As políticas urbano-territoriais e os planos que conduzem estrategicamente a reprodução da metrópole (levando em conta o processo de urbanização) destacam o Centro de São Paulo e seu entorno como uma nova estratégia inerente ao processo de revalorização. A noção de cultura se ampliou nestas propostas, conforme vimos: do território cultural (eixo Paulista-Luz) para a economia criativa, e daí para os polos da moda. Ao ser ampliada, a noção de cultura torna-se uma estratégia que se realiza em conjunto com as intervenções que ocorrem no espaço, da mesma forma que compõe uma articulação e complementaridades entres políticas de intervenção e as leis. O Centro e seu entorno revelam, através das suas políticas, as estratégias do Estado para compor a nova fronteira urbana de acumulação, tanto com os empreendimentos imobiliários ${ }^{226}$ (sejam eles novos ou derivados de reformas completas) quanto com as atividades e práticas econômicas que permitem o consumo do espaço, como é o caso do turismo. Ao mobilizar as políticas e os planos de intervenção no espaço, o Estado também municia o setor imobiliário para o desenvolvimento de estratégias de lançamento de novos empreendimentos no Centro de São Paulo. Ao propiciar tais condições, o Estado promove diretamente, por meio de mecanismos específicos, o processo de segregação socioespacial, afinal, é por meio destas condições que fomentam a produção de novos negócios imobiliários que as formas de acesso à cidade e a vida urbana tendem a se realizar por meio das relações de compra e venda de parcelas do espaço. O fundamento do

${ }^{226}$ Ver Anexo 03. 
valor de troca, torna-se o imperativo para que esta relação sinérgica entre Estado e capital se realize por meio da reprodução do Centro de São Paulo.

As formas de acesso à cidade por meio do mercado limitam os acessos ao mesmo tempo em que restringe, produz àquilo que nega este processo enquanto formas de resistência na luta pela permanência no espaço. A segregação socioespacial no Centro de São Paulo e as resistências a este processo limitador das formas de acesso, revelam, na atualidade, um espaço em disputa cujo interesse de cada grupo se diferencia conforme o interesse de sua classe social. Dessa forma, a reprodução capitalista da metrópole encontra limites nas contradições derivadas de seu movimento histórico, causando entraves para a acumulação tendencial apontada na reprodução deste fragmento da cidade. Além destes limites marcados no movimento histórico constitutivo da metrópole, vale salientar também que o maior fator limitador à reprodução do Centro de São Paulo é seu próprio espaço rarefeito, superedificado, hiperfragmentado, em excesso e acumulado, concentrado.

Limites e fronteiras caracterizam de forma significativa, tanto o processo de segregação socioespacial quanto a reprodução da metrópole enquanto uma sobrevida ao processo de acumulação capitalista. O Centro e seu entorno, à luz do mercado imobiliário e do Estado, constituem-se numa tendência (portanto, aquilo que tende e vislumbra no devir uma possibilidade posta, mas que não é certa) à acumulação de capital por meio da reprodução do espaço. De certa forma, são as superações das fronteiras e limites - por meio de formas de violências institucionalizadas, pilhagens, espoliações e expropriações atuais - que faz com que o capitalismo se mantenha em curso, por meio de um "falso equilíbrio". A produção do espaço, ou, a reprodução do espaço historicamente e socialmente produzido das cidades, se realiza e tende, cada vez mais, a se tornar uma sobrevida ao processo de acumulação, afinal, a extensão do capital ao espaço (como também sua extensão, ou tendência de extensão, à todas as formas sociais que foram produzidas) revela a lógica do mundo da mercadorias em que o valor de troca incorpora tudo aquilo que "toca". Ao mesmo tempo em que a produção do espaço, enquanto um processo produtivo com características específicas, torna-se uma sobrevida à acumulação de capital, esta forma de produção também faz emergir uma dimensão atual das lutas de classes.

O conflito entre as classes sociais, no caso da reprodução do Centro de São Paulo, surge através dos interesses distintos que as classes sociais têm pelo espaço socialmente produzido dos distritos que compõem a área central da metrópole. Enquanto para uma burguesia ligada à indústria do imobiliário o Centro torna-se um espaço com possibilidades significativas de acumulação, para os indivíduos que compõem uma fração da pequeno- 
burguesia, o Centro (enquanto um lugar marcado por suas representações ligadas à cultura) torna-se um lugar que preenche determinados anseios ligados ao habitar; porém, há também, em sua grande maioria, a presença significativa do proletariado que, atualmente, compõem a maior parte da parcela da população que habita este fragmento da metrópole. Para este proletariado, por sua vez, o Centro torna-se o lugar de realização e de reprodução da vida, cujas possibilidades de apropriação do espaço (em alguns casos) potencializam ainda mais esta dimensão em que o espaço torna-se condição, meio e produto para a reprodução dos sujeitos.

Tendo em vista essa relação de tensão entre as classes sociais, conforme há a especificidade de interesses respectivos de cada uma delas pelo espaço, há também a dimensão do conflito e das lutas, também pelo espaço. Ao se constituírem no movimento desta forma de produção, as tensões tornam-se "naturalmente" um limite à reprodução capitalista da metrópole. Ao produzir tanto aquilo que afirma a segregação em função do imperativo do valor de troca e da extensão da forma-mercadoria ao espaço, quanto naquilo que a segregação produz como positivo à cidade e à vida urbana, decorrentes das formas de transgressão, resistência e apropriação do espaço, as próprias condições do real forjado nas formas de lutas que surgem das classes sociais tornam-se os limites e fronteiras para a acumulação do capital, através do processo de reprodução-revalorização do Centro de São Paulo.

Se por um lado o Centro de São Paulo e seu entorno tornam-se o espaço em que, por meio de disputa, põem em "jogo" são as possibilidades de acumulação e apropriação, por outro lado, compete ao Estado, conforme discorremos no primeiro capítulo, reverter este conflito que se tornou um "impasse" a partir da propriedade privada do espaço, posta pela disputa entre as classes sociais. Neste sentido, tanto a problematização quanto à crítica às estratégias do Estado se constituem e são elaboradas nesta pesquisa, afinal, além de contribuir com as estratégias de revalorização (ao ser o ente que, além de produzir o espaço por um viés político, produz também suas representações), há o papel significativo também no controle e progressão das formas de resistência. Portanto, se por um lado o embate entre as classes sociais tornam-se um limite à reprodução do Centro de São Paulo, por outro, o Estado passa a ser a via institucional em que tanto o embate quanto os "impasses" que resultam deste embate ganham a possibilidade de serem revertidos. A dominação e o Estado enquanto forma é um fato que deve ser considerado à parte neste processo revalorização do Centro e, por conseguinte, na configuração do processo de segregação socioesapacial. 
O espaço, enquanto uma forma com potência de realização no capitalismo, revela em seus conteúdos a expressão do próprio processo de produção. Produção e acumulação tornamse condições significativas para a reprodução do capitalismo, e a produção do espaço (alívio e sobrevida às crises deste regime) transforma agressivamente a metrópole, ainda mais quando são consideradas as transformações nos lugares densamente ocupados, como é o caso do Centro de São Paulo e seu entorno imediato. Nestes termos, a reprodução do Centro de São Paulo sob as determinantes da realização do lucro, o metamorfoseia em capital fixo, tornandoo também condição para a realização do processo de revalorização, enquanto um momento do processo de valorização diferenciada dos lugares que ocorre na escala da metrópole. O que convém salientar é que o seu processo de reprodução torna-se o momento estratégico de reversão da contradição da raridade do espaço (superedificado e marcado pelos excessos e acúmulos dos conteúdos do processo de urbanização da metrópole) em que a reversão da contradição se realiza através da expansão de novas fronteiras espaciais para o entorno dos distritos que compõem o Centro de São Paulo (Sé e República).

A reprodução capitalista do Centro de São Paulo se constitui também como o momento que exige, necessariamente, a ação política e estratégica do Estado, afinal, esta ação (e lógica) tende a se impor para destruir as fronteiras entre os bairros, como também destruir as fronteiras dentro dos bairros ${ }^{227}$, através da imposição de estratégias que homogeneízam as paisagens e os padrões arquitetônicos.

Assim, nessa segunda década do século XXI, as políticas para o Centro de São Paulo revelam tanto as táticas de reforma das estruturas arquitetônicas (independente de serem estas públicas ou privadas), quanto às estratégias ligadas a expansão de sua fronteira, visando o entorno imediato, ainda mais quando consideramos os distritos que os circundam, compondo aquilo que vem sendo considerado tanto pela iniciativa privada quanto pelo Estado como área central. Este ponto é central para o entendimento e movimento desta dissertação e o referencial principal que conduz estas considerações, decorre de uma leitura sobre as asseverações de Andrea Tourinho ${ }^{228}$. De acordo com a exposição de Tourinho (2001), aquilo que a autora avalia como considerações conceituais são compreendidas em sua tese como considerações de caráter operativo que caracterizam a área central, e são distinguidas pelos

\footnotetext{
${ }^{227}$ Carlos, 2001, p. 281.

${ }^{228}$ TOURINHO, A. Do centro aos centros: bases teórico-conceituais para o estudo da centralidade em São Paulo. Tese de Doutorado. FAU-USP, 2001. O "diálogo" se realiza mais com o subcapítulo 2 (Centro, cidade central e área central: uma diferenciação necessária) do Capítulo VI (Centro e centralidade na São Paulo contemporânea).
} 
distritos Sé (Centro Velho) e República (Centro Novo) e o conjunto de bairros ${ }^{229}$ centrais formado por Consolação, Santa Cecília, Bom Retiro, Pari, Brás, Cambuci, Liberdade e Bela Vista. A autora também expõe outra assertiva naquilo que considera como limex, na qual considerou sobre aquilo que chamou de "faixa de incerteza em volta do Centro, que ainda não é bairro, sendo uma faixa relativamente variável, mutável, indefinida ou, pelo menos, arredia a definições" (TOURINHO, 2001, p. 334).

A importância deste movimento de exposição, levando em conta do que é o Centro (nas figuras dos distritos Sé e República) ou mesmo o que é a área central (levando em conta os distritos que compõem o entorno daqueles dois distritos), ocorre pelo fato de que, não apenas os distritos que compõem o Cento na figura do Centro Velho e do Centro Novo, como também os distritos que são limítrofes e contíguos a estes, compõem um fragmento de intervenção que, tanto o Estado quanto à iniciativa privada, acabam conferindo como Centro no ato de seus interesses e intervenções. A questão é que dos interesses operacionais (estratégicos e políticos) postos em prática pelo Estado, aos interesses da iniciativa privada que investe seu capital por meio de empreendimentos imobiliários que caracterizam a reprodução do espaço, o que está em voga é uma apropriação estratégica das condições atuais que, além de produzirem o espaço, redefinem seus conteúdos e, por conseguinte, suas representações para fins específicos. Andrea Tourinho ${ }^{230}$ ainda salienta em seu texto que, dependendo dos estudos, a área central pode chegar até a Barra Funda (de acordo com a Associação Viva o Centro) ou mesmo até a Avenida Paulista (conforme o território do PROCENTRO).

Conforme fazemos o esforço de asseverar, são os conteúdos dos interesses inerentes a estas instituições (a Associação Viva Centro e o Estado, este por meio das suas políticas de intervenção no espaço), que redefinem, somados as empresas privadas ligadas à indústria do imobiliário, os conteúdos do que é ou o que não é o Centro de São Paulo. Ou seja, as redefinições das representações e dos conteúdos do que vai ser ou não caracterizado como Centro passam, antes de qualquer coisa, pelo crivo da produção do espaço. Além dessas redefinições, a apropriação estratégica do espaço, além de caracterizar uma sinergia entre Estado e capital, caracteriza também o envolvimento dos três níveis e escalas ${ }^{231}$ que caracterizam este tipo de produção. No que tange as delimitações de territórios estratégicos,

\footnotetext{
${ }^{229}$ Nesta dissertação a nomeação dada, a estes que Tourinho chamou de bairros, foi a de distritos. Afinal, há ainda nestes distritos aquilo que compreendemos como bairros, por exemplo, no distrito República há o bairro Santa Ifigênia, no Bom Retiro o bairro da Ponte Pequena, no Pari o bairro Canindé, no distrito Santa Cecília a Vila Buarque, e assim por diante.

${ }^{230}$ Tourinho, 2001, p. 335 (nota de rodapé 597).

${ }^{231}$ Carlos, 2011, p. $74-89$.
} 
expusemos os territórios inerentes às políticas de intervenção no espaço e, tanto no conteúdo das políticas quanto em seus territórios específicos, o objeto direto da ação do Estado, além dos distritos Sé e República, também se realizavam, predominantemente, nestes distritos do entorno. Além da realização no plano do Estado, há também a realização no plano das entidades de classe e, neste caso, a Associação Viva o Centro é o principal expoente das intervenções e delimitações estratégicas, inclusive em função do seu próprio território de atuação.

Assim, as redefinições sobre os conteúdos e os sentidos da área central passam, antes de tudo, pelo crivo do Estado para que possam ser, em seguida, apropriados enquanto condição para a reprodução do Centro de São Paulo. Neste caso, a Associação Viva o Centro contempla um papel preponderante neste processo, afinal, ela representa uma aliança de classe que, além de instituir oficialmente que o Centro é um espaço em disputa entre classes sociais distintas, revela também a proximidade, a relação, a sinergia e, até mesmo a complementaridade, entre o Estado e a burguesia nesta realidade de tensões. A revalorização do Centro de São Paulo, seja por meio das estratégias de delimitação dos territórios, seja por meio da atribuição de novos conteúdos às paisagens, ou seja, por meio da transformação dos conteúdos dos lugares, é um processo atravessado por interesses distintos, portanto, interesse entre classes sociais que, por sua vez, expressam uma Geografia peculiar.

O processo de revalorização do Centro de São Paulo é também seu processo de reprodução enquanto condição de valorização do valor, ainda mais quando levamos em conta que sua realidade atual está assentada e, ao mesmo tempo, acentuada nos conteúdos da reprodução capitalista do espaço. Ou seja, somente quando as condições do desenvolvimento histórico permitiram a acumulação dos excessos (também históricos e que explodiramimplodiram os conteúdos da metrópole) foi que, no Centro, em função da sua desvalorização, o processo de reprodução ganhou conteúdos que se tornaram significantes a esta realidade, configurando-o, assim, no cerne da reprodução capitalista da metrópole. Neste movimento, o objetivo dessas transformações no espaço consiste em devolver à circulação o Centro "requalificado", "revitalizado" e, por conseguinte, revalorizado, nos termos de um novo valor de uso; este, por sua vez, produzido politicamente por meio de novas representações que são atribuídas ao espaço ${ }^{232}$.

${ }^{232}$ Geralmente associadas ao álibi da cultura e tudo que possa derivar desta condição. 
Entre esses acúmulos e excessos ${ }^{233}$, o acúmulo do saber fazer ${ }^{234}$ também produziu uma relação entre a produção em larga escala (ainda mais quando levamos em conta a indústria da construção civil) e as possibilidades que, cada vez mais, permitiu o aumento da mobilização de dinheiro em torno da propriedade fundiária e seus rendimentos. Essa relação entre a indústria da construção civil e as condições que surgem no domínio do processo de urbanização, levou ao surgimento (na esfera da reprodução da cidade e do urbano) dessa que podemos considerar, talvez, como a indústria do imobiliário. O surgimento (ou mesmo a articulação) de novos setores da produção ocorre na relação com os setores já consolidados da economia enquanto possibilidade de reverter à contradição fundante do modo capitalista de produção, ou seja, aquela ligada à tendência a baixa da taxa de lucro que, em sua essência, se realiza conforme há o desenvolvimento do próprio capitalismo enquanto modo de produção.

A quantidade significativa de trabalho acumulado que caracteriza o espaço, faz do Centro de São Paulo (assim como também seu entorno imediato) um espaço atravessado por interesses, que não deixam de ser também interesses de classe. A sobrevida permitida ao capital, a partir da cidade e do urbano - e nesse caso, a partir do Centro, seu entorno e seus conteúdos - somente se torna possível através do desenvolvimento da produtividade social do trabalho em que a massa dos valores de uso produzidos se metamorfoseia, também, em meios de produção ${ }^{235}$ (inclusive aqueles que são meios de subsistência e manutenção da vida, como é o caso do espaço).

A metrópole é o resultado histórico deste movimento, ainda mais quando concebida através do processo que vai da forma predominante do uso para a forma predominante da troca. Ou seja, é na forma em que se efetiva o uso que as condições para a troca estão dadas, contudo, levando em consideração esta finalidade (o uso), todo tipo de produção que visa o valor - ou a valorização do valor - será, por excelência, produção capitalista. Neste movimento, (POSTONE, 2015, p. 208-2012) faz ressalvas significativas sobre aquilo que considera como instrumentalização do mundo determinada pela produção; e assevera que "a produção no capitalismo se torna um meio para um meio". Por mais que o autor, ao longo da sua exposição, não "feche" sua consideração sobre o que é o meio, isso talvez deve ocorrer por que cada produção, para além da acumulação, deve também ter outros significados. No caso da produção do espaço, este tipo de produção, além de ser um meio para a acumulação,

\footnotetext{
${ }^{233}$ Que não se restringem apenas aos conteúdos da morfologia espacial e são compostos também pela morfologia social em sua composição de sociedade cindida em classes sociais.

${ }^{234}$ Gerador de formas específicas de conhecimento para os diversos tipos de produção capitalista, ainda mais quando consideramos os conhecimentos voltados à produção do espaço urbano: urbanismo, engenharia civil, incorporação imobiliária, marketing urbano, engenharia urbana etc.

${ }^{235}$ Ibidem, p. 289.
} 
torna-se também um meio para a dominação que permite a continuidade estratégica das condições de reprodução das relações sociais postas; neste caso, o que torna sua noção ampliada das demais formas de produção que ocorrem no capitalismo.

Carlos (2015, p. 54) destaca que enquanto condição de aplicação de capital (para que este se valorize), a metrópole redefine seu espaço e assume a condição de capital fixo. Nestes termos, a produção do espaço torna-se condição, meio e produto para a realização do ciclo do capital $^{236}$, ao mesmo tempo em que é caracterizada por sua temporalidade específica. A revalorização do Centro de São Paulo, que também contempla seu processo de reprodução, faz com que este fragmento da metrópole assuma essa dupla condição: como capital fixo e como força produtiva. Enquanto capital fixo, a potência de sua transformação se realiza através dos próprios mecanismos ligados as redefinições dos sentidos e representações do espaço, levando em conta a finalidade da revalorização. A revalorização do Centro de São Paulo, por sua vez, apenas adquire novos conteúdos porque seu espaço torna-se uma estrutura que porta todas as condições para a reprodução do capital por meio de sua própria reprodução, que se apropria daquilo que foi produzido historicamente (rede de troca, circulação de mercadorias, concentração de pessoas, unidades de produção, fluxos diversos etc.), conforme os conteúdos de seu excesso. Carlos $(2015$, p.49) nos auxilia na composição deste movimento de pensamento, conforme assevera que

\footnotetext{
o espaço de acumulação, produto e condição geral da produção, além de instrumento político ligado ao Estado, o qual transforma as condições gerais necessárias ao desenvolvimento do capital a fim de superar as contradições emergentes no seio do processo de reprodução ampliada e controlar sua expansão, já que denomina a reprodução social.
}

No que tange aos álibis e/ou justificativas dessas novas representações do espaço, a revalorização do Centro de São Paulo se realiza principalmente àqueles ligados à cultura. $\mathrm{O}$ álibi ou justificativa da cultura, além de vender os produtos imobiliários, além de fazer com que o próprio espaço seja um objeto de venda através das formas de consumo (como é o caso do turismo), faz também com que o comprador (ou possível comprador), também esteja realizando no ato da aquisição a compra de um peculiar estilo de vida urbano atrelado à cultura. O movimento da reprodução do Centro de São Paulo, revela, em seu processo de revalorização, a produção do espaço com base na produção de um novo valor de uso para o espaço, cujos esforços (tanto do capital privado quanto, principalmente, do Estado em suas

${ }^{236}$ Carlos, 2015, p. 47. 
estratégias) são concentrados na afirmação de uma representação do espaço através dos conteúdos da cultura.

A reprodução do Centro e suas estratégias de revalorização, ao produzirem para a venda um espaço-mercadoria específico, lançam a um grau significativo (talvez ainda não visto) o fenômeno da alienação. Por exemplo, a tendência é que ao vender algum produto imobiliário localizado no Centro ou mesmo em seu entorno, vendem uma representação de um fragmento específico da metrópole, como também vendem uma forma específica da vida urbana que tende a se realizar em função destes conteúdos estrategicamente produzidos. A produção do espaço por meio dessas estratégias (tanto do Estado quanto do capital) acaba lançando o próprio homem para uma esfera (e/ou grau) de alienação que somente torna possível no atual estágio histórico. Este grau de alienação não pode ter sua abstração relacionada às formas redutoras de concepção da realidade. Pelo contrário, sua problemática, enquanto uma problemática atual, somente se faz presente pelo fato desta decorrer da realidade urbana, cujas novas problemáticas tendem a apontar para alguns traços atuais que caracterizam a sociedade urbana.

O espaço social e historicamente produzido do Centro de São Paulo é, atualmente, resultado do desenvolvimento das forças produtivas e das relações de produção na metrópole ${ }^{237}$. O Centro, atualmente e em função da sua reprodução/revalorização, torna-se o espaço produtivo, portador de uma prática social (e estatista) específica - instrumental e abstrata - ligada a uma relação de produção que visa a reprodução e que permite considerá-lo enquanto uma das dimensões da força produtiva que transforma e reproduz a metrópole e o urbano. Sua revalorização é uma forma de incrementar cada vez mais essas massas de valores de uso, novos valores de uso, abstratamente, estrategicamente e politicamente produzidos para efetivar a forma-mercadoria; ao mesmo tempo em que sua reprodução o revela enquanto condição e meio para a realização do lucro e da acumulação.

A reprodução do Centro de São Paulo expressa significativamente a ampliação da noção de produção do espaço, afinal: a) neste processo a cidade torna-se força produtiva; b) o Centro (em função de seus lugares e toda sua estrutura e infraestrutura) torna-se capital fixo; c) o processo de revalorização do Centro é caracterizado pela "confecção" de um produto específico, marcado pelo álibi da cultura; d) visa reverter à contradição da raridade do espaço, expandindo espacialmente a reprodução como forma de desobstruir tanto as fronteiras entre os bairros quanto as fronteiras dentro dos bairros; e) é marcada pelo interesse e iniciativa de

${ }^{237}$ Do "café" à industrialização, e da industrialização ao financeiro e terciário avançado. 
classes sociais opostas que disputam o espaço, principalmente no campo político (marcado pelas ideologias e representações de classes); f) conforme esta polarização entre as classes, o Centro expressa possibilidades e tendências, ou descontinuidades e continuidades.

As estratégias, as políticas urbano-territoriais e os planos que conduzem estrategicamente a reprodução da metrópole (levando em conta o processo de urbanização) destacam o Centro de São Paulo e seu entorno como uma nova estratégia inerente ao processo de revalorização. A noção de cultura se ampliou nestas propostas, conforme vimos: agora, o que está posto é um território cultural (eixo Paulista-Luz) para a economia criativa, como também para os polos da moda. O Centro e seu entorno revelam, através das suas políticas, as estratégias do Estado para comporem a nova fronteira urbana de acumulação tanto com os empreendimentos imobiliários quanto com as atividades e práticas econômicas que permitem o consumo do espaço através do turismo, como vimos também anteriormente. $\mathrm{O}$ controle do Estado realiza-se por meio de estratégias que se revelam no movimento em que a reprodução capitalista da metrópole a transforma em força produtiva, através das próprias condições e meios que estão postos pelo espaço. A reprodução também capitalista do Centro de São Paulo e seu entorno é caracterizada por interesses e imperativos do capital que tendem a transformar por completo o lugar, ao mesmo tempo em que entram em choque com as resistências que transgridem as condições postas, por meio da prática socioespacial que, em sua origem, faz-se irredutível às mudanças. 


\section{BIBLIOGRAFIA}

\section{BIBLIOGRAFIA UTILIZADA}

ALVES, G. A. São Paulo: uma cidade global. In. Urbanização e mundialização: estudos sobre a metrópole. Ana Fani Alessandri Carlos, Carles Carreras (organizadores). São Paulo: Contexto, 2005.

O uso do centro da cidade de São Paulo e sua possibilidade de apropriação. São Paulo: FFLCH, 2010.

A requalificação do centro de São Paulo. Estudos avançados [online]. 2011, vol.25, n.71, pp. 109-118.

ARANTES, O. Uma estratégia fatal: a cultura nas novas gestões urbanas. In. A cidade do pensamento único: desmanchando consensos. Otília Arantes, Carlos Vainer, Ermínia Maricato (orgs). 7. ed. Petrópolis, RJ: Vozes, 2012.

Berlim e Barcelona: duas imagens estratégicas. São Paulo: Annablume, 2012a.

AZEVEDO, A. São Paulo, cidade trimilionária. In. Aroldo de Azevedo (org.). A cidade de São Paulo. Estudos de Geografia Urbana. Volume I. A região de São Paulo. São Paulo: Companhia Editora Nacional, 1958.

DUSSEL, Henrique. A produção teórica de Marx: um comentário do Grundrisse. São Paulo: Expressão Popular, 2012.

BOLAFFI, R. Habitação e urbanismo: o problema e o falso problema. In. A produção capitalista da casa (e da cidade). Ermínia Maricato (organizadora). São Paulo: Editora AlfaÔmega, 1982.

BONDUKI, N e ROLNIK, R. Periferia da grande São Paulo. Reprodução do espaço como expediente da reprodução da força de trabalho. In. A produção capitalista da casa (e da cidade). Ermínia Maricato (organizadora). São Paulo: Editora Alfa-Ômega, 1982.

BORJA, J; FORN, M. Políticas da Europa e dos Estados para as cidades. Espaço e Debates. Revista de Estudos Regionais e Urbanos. São Paulo. Ano XIV - 1996 - nº 39. 
BRENNER, N.; THEODORE, N.; PECK, J. Urbanismo neoliberal: la ciudad y el imperio de los mercados. TEMAS SOCIALES nº 66, marzo 2009. Santiago, Chile.

CANTON, A. L. Preservação contraditória no Centro de São Paulo: degradação das Vilas Preservadas na Baixada do Glicério no contexto da renovação urbana (Operação Urbana Centro). 2007. 89f. Orientadora: Prof. ${ }^{a}$ Dr. $^{\text {a }}$ Odette Carvalho de Lima Seabra. Dissertação (Mestrado em Geografia Humana). - Faculdade de Filosofia, Letras e Ciências Humanas. Universidade de São Paulo. São Paulo.

CARLOS, A. F. A. A tragédia urbana. In. Ana Fani Alessandri Carlos, Danilo Volochko, Isabel Pinto Alvarez (orgs). A cidade como negócio. São Paulo: Contexto, 2015.

A produção da metrópole: o novo sentido do solo urbano na acumulação de capital. In. Ana Clara Torres Ribeiro, Ester Limonad, Paulo Ferreira Gusmão (orgs.). Desafios do planejamento: produção da metrópole e questões ambientais. Rio de Janeiro: Letra Capital: ANPUR, 2012.

A condição urbana. São Paulo: Contexto, 2011.

Da "organização" à "produção" do espaço no movimento do pensamento geográfico. In. Ana Fani Alessandri Carlos, Marcelo Lopes de Souza, Maria Encarnação Beltrão Sposito (orgs). A produção do espaço urbano: agentes e processos, escalas e desafios. São Paulo, Contexto, 2011a.

São Paulo: do capital industrial ao capital financeiro. In. Ana Fani Alessandri Carlos, Ariovaldo Umbelino de Oliveira (orgs.). Geografias de São Paulo: a metrópole do século XXI. São Paulo: Contexto, 2004.

Espaço-tempo na metrópole. São Paulo: Contexto, 2001.

CASTILHO, J. R. F. Disciplina urbanística da propriedade: o lote e seu destino. 3. ed. reform. São Paulo: Editora Pillares, 2010.

CORDEIRO, H. K. O centro da metrópole paulistana: expansão recente. IGEOG - USP. Série Teses e Monografias. № 40. São Paulo, 1980.

COUTO, L. R. Nem só o que é sólido se desmancha no ar: a Nova Luz na produção insubstancial do espaço urbano. 2011. 202f. Orientador: Prof. Dr. Anselmo Alfredo. 
Dissertação (Mestrado em Geografia Humana). - Faculdade de Filosofia, Letras e Ciências Humanas. Universidade de São Paulo. São Paulo.

CYMBALISTA et al. Controle social de políticas públicas: o financiamento do BID para a reabilitação do Centro de São Paulo. São Paulo: POLIS, Instituto de Estudo, Formação e Assessoria em Políticas Sociais, 2008.

DAMIANI, A. L. A Cidade (des)ordenada: concepção e cotidiano do conjunto habitacional Itaquera I. 1993. Tese (Doutorado em Geografia), Universidade de São Paulo, 1993.

DUMÉNIL, G; LÉVY,D. A crise do neoliberalismo. São Paulo: Boitempo, 2014.

DUSSEL, H. A produção teórica de Marx: um comentário ao Grundrisse. São Paulo: Expressão Popular, 2012.

ESQUINCA, M. M. M. Os deslocamentos territoriais dos adultos moradores de rua nos bairros Sé e República. 2013. 254f. Orientadora: Prof. ${ }^{\text {a }}$ Dr. ${ }^{a}$ Maria Ruth Amaral de Sampaio. Dissertação (Mestrado em História e Fundamentos da Arquitetura e Urbanismo). Faculdade de Arquitetura e Urbanismo. Universidade de São Paulo. São Paulo.

FERREIRA, J. S. W. São Paulo: o mito da cidade global. 2003. 336f. Orientadora: Prof. ${ }^{a}$ Dr. $^{a}$ Ermínia Terezinha Menon Maricato. Tese (Doutorado em Estruturas Ambientais Urbanas). Faculdade de Arquitetura e Urbanismo. Universidade de São Paulo. São Paulo.

FERRO, S. O canteiro e o desenho. In. Sério Ferro. Arquitetura e trabalho livre. São Paulo: Cosac Naify, 2006.

FRÚGOLI JR., H. Centralidade em São Paulo: trajetórias, conflitos e negociações na metrópole. São Paulo: Cortez: Editora da Universidade de São Paulo, 2000.

FUZO, A. Procuram-se apartamentos no Centro (entrevista com o vereador José Police Neto). Revista Urbs, São Paulo: Associação Viva Centro, Ano X, №50 - 2º trimestre, 2009.

GRILLO, M. T. O. Industrialização e desindustrialização do município de São Paulo. São Paulo. 1997. Dissertação (Mestrado) - Curso de Pós-Graduação em Arquitetura e Urbanismo. Faculdade de Arquitetura e Urbanismo. Universidade de São Paulo. Orientadora: Prof. Dr. Candido Malta Campos Filho. 
HAESBAERT, R. Dilema de conceitos: espaço-território e contenção territorial. In. Marcos Aurélio Saquet e Eliseu Savério Sposito (orgs.). Territórios e territorialidades: teorias, processos e conflitos. São Paulo: Expressão Popular: UNESP. Programa de Pós-Graduação em Geografia, 2009.

HARVEY, D. Cidades rebeldes: do direito à cidade à revolução urbana. São Paulo: Martins Fontes, 2014.

. O novo imperialismo. São Paulo: Edições Loyola, 2012a.

O neoliberalismo: história e implicações. São Paulo: Edições Loyola, 2012b.

Condição Pós-Moderna: uma pesquisa sobre as origens da mudança cultural. São Paulo: Edições Loyola, 2008.

A produção capitalista do espaço. São Paulo: Annablume, 2005.

HIRSH, J. Teoria materialista do Estado: processos de transformação do sistema capitalista de Estado. Rio de Janeiro: Revan, 2010.

JAMESON, F. A virada cultural: reflexões sobre o pós-modernismo. Rio de Janeiro: Civilização Brasileira, 2006.

KARA-JOSÉ, B. A popularização do Centro de São Paulo: um estudo de transformações ocorridas nos últimos 20 anos. 2010. 264f. Orientador: Prof. Dr. Flávio Villaça. Tese (Doutorado em Planejamento Urbano e Regional). Faculdade de Arquitetura e Urbanismo. Universidade de São Paulo. São Paulo.

KOWARICK, Lúcio. A espoliação urbana. Rio de Janeiro: Paz e Terra, 1979.

LEFEBVRE, H. A revolução urbana. Belo Horizonte: Ed. UFMG, 1999.

La production de l 'espace. Paris: Anthropos, 2000.

A respeito do Estado. Tomo IV: As contradições do Estado Moderno. In. De l'Etat. Paris: Union Génerale d’Editions, 1976. Tradução provisória do capitulo "V. L'espace et 1'Etat" (p. 259-234), por José Augusto Martins Pessoa.

A re-produção das relações de produção. Porto (Portugal): Publicações Escorpião, 1973. 
LENCIONI, S. Reestruturação urbano-industrial no Estado de São Paulo: a região da metrópole desconcentrada. Espaço e Debates. Revista de Estudos Regionais e Urbanos. São Paulo. Ano XIV - 1994 - no 38.

LIMA, S. M. S. Polos criativos: um estudo sobre os pequenos territórios criativos brasileiros. Brasília 2011-2012. Disponível em:

http://www2.cultura.gov.br/economiacriativa/wp-content/uploads/2013/06/poloscriativos.pdf

LIPOVETSKY, G; SERROY, J. A cultura-mundo: resposta a uma sociedade desorientada. São Paulo: Companhia das Letras, 2011.

A estetização do mundo: viver na época do capitalismo artista. São Paulo: Companhia das Letras, 2015.

MARICATO, E. O impasse da política urbana no Brasil. Petrópolis, RJ: Vozes, 2014.

Brasil, cidades: alternativas para uma crise urbana. Petrópolis, RJ: Vozes, 2013.

O urbanismo na periferia do capitalismo: desenvolvimento da desigualdade e contravenção sistemática. In. Maria Flora Gonçalves (org.). O novo Brasil urbano: impasses, dilemas, perspectivas. Porto Alegre: Mercado Aberto, 1995.

Autoconstrução, a arquitetura possível. In. A produção capitalista da casa (e da cidade). Ermínia Maricato (organizadora). São Paulo: Editora Alfa-Ômega, 1982.

MARTINS. J. S. O cativeiro da terra. São Paulo: Contexto, 2013.

MARX, Karl. O capital: crítica da economia política: Livro I: o processo de produção do capital. São Paulo: Boitempo, 2013.

Grundrisse: manuscritos econômicos de 1857 - 1858: esboços da crítica da economia política. São Paulo: Boitempo, 2011.

Para a crítica da economia política. "Manuscrito de 1861 - 1863 (cadernos I a V) - Terceiro Capítulo. O capital em Geral”. Belo Horizonte: Autêntica Editora, 2010.

O capital: crítica da economia política, livro terceiro: o processo global de produção capitalista, volume VI. Rio de Janeiro: Civilização Brasileira, 2008. 
MARX, K.; ENGELS, F. A ideologia alemã: crítica da mais recente filosofia alemã em seus representantes Feuerbach, B. Bauer e Stirner, e do socialismo alemão em seus diferentes profetas (1845 - 1846). São Paulo: Boitempo, 2007.

MASCARO, A. L. B. Estado e forma política. São Paulo: Boitempo, 2013.

Introdução ao estudo do direito. São Paulo: Atlas, 2013a.

MEIRELLES, H. C. O Centro como protagonista, Henrique de Campos Meirelles. Revista Urbs, São Paulo: Associação Viva Centro, Ano X, N42 - Edição especial. Dezembro, 2006. MENEGAT, M. Estudos sobre ruínas. Rio de Janeiro: Revan: Instituto carioca de criminologia, 2012.

MOTISUKE, D. Reabilitação de áreas centrais: antagonismos e ambiguidades do programa paulistano Ação Centro. 2008. 217f. Orientador: Prof. Dr. João Sette Whitaker Ferreira. Dissertação (Mestrado em Habitat). Faculdade de Arquitetura e Urbanismo. Universidade de São Paulo. São Paulo.

MÜlleR, N. L. A área central da cidade. In. Aroldo de Azevedo (org.). A cidade de São Paulo. Estudos de Geografia Urbana. Volume III. Aspectos da metrópole paulista. São Paulo: Companhia Editora Nacional, 1958.

NEVES, R. H. Os impactos da atuação do Banco Interamericado de Desenvolvimento (BID) nas Políticas Públicas Brasileiras: o caso do programa de reabilitação da área central - PROCENTRO. 66f. 2012. Dissertação (Mestrado em Administração Pública) Orientador: Francisco Fonseca - Escola de Administração de Empresas de São Paulo da Fundação Getúlio Vergas - EAESP.

PACCA, P. E. A estagnação urbana como parte da metrópole paulistana do século XXI o caso do Pari. 2010. 287f. Orientadora: Prof. Dr. Flávio Villaça. Tese (Doutorado em Planejamento Urbano e Regional). Faculdade de Arquitetura e Urbanismo. Universidade de São Paulo. São Paulo.

PETRONE, P. São Paulo no século XX. In. Aroldo de Azevedo (org.). A cidade de São Paulo. Estudos de Geografia Urbana. Volume I. A evolução urbana. São Paulo: Companhia Editora Nacional, 1958. 
POSTONE, M. Tempo, trabalho e dominação social: uma reinterpretação da teoria crítica de Marx. São Paulo: Boitempo, 2014.

ROJAS, E. Financiando la conservación del patrimonio urbano em América Latina y el Caribe: la acción del Banco Interamericano de Desarollo. In. Fernando Carrión (ed.). Centros Históricos de América Latina y Caribe. Quito, Ecuador: FLACSO, 2001.

RODRIGUES, M. Preservar e consumir: o patrimônio histórico e o turismo. In. Pedro Paulo Funari e Jaime Pinsky (orgs.). Turismo e patrimônio cultural. São Paulo: Contexto, 2003.

SAMPAIO, R. A. A violência do processo de urbanização. In. Ana Fani Alessandri Carlos (org.) Crise Urbana. São Paulo: Contexto, 2015.

Da noção de violência urbana à compreensão da violência como processo de urbanização: apontamentos para uma inversão analítica a partir da Geografia Urbana. 2011. 148f. Orientadora: Prof. ${ }^{a}$ Dr. ${ }^{a}$ Ana Fani Alessandri Carlos. Dissertação (Mestrado em Geografia Humana). - Faculdade de Filosofia, Letras e Ciências Humanas. Universidade de São Paulo. São Paulo.

SANFELICI, D. M. Urbanismo neoliberal e gentrificação: as políticas de revitalização do Centro de Porto Alegre/RS. Ciências \& Letras, Porto Alegre, n.41, p.188-203, jan./jun. 2007. Acessado em Fevereiro de 2015. Disponível em: http://www4.fapa.com.br/cienciaseletras/pdf/revista41/Artigo_Daniel.pdf

SANTOS, C. R. S. A nova centralidade da metrópole: da urbanização expandida à acumulação especificamente urbana. 2013. 321f. Orientadora: Prof. ${ }^{a}$ Dr. ${ }^{a}$ Ana Fani Alessandri Carlos. Tese (Doutorado em Geografia Humana) - Faculdade de Filosofia, Letras e Ciências Humanas. Universidade de São Paulo. São Paulo.

SANTOS, M. Técnica, Espaço, Tempo: Globalização e Meio Técnico-científicoinformacional. 5. ed., 1. reimpr. São Paulo: Editora da Universidade de São Paulo, 2013.

SEABRA, O. C. L. Urbanização e fragmentação: a natureza natural do mundo. GEOGRAFARES, Vitória, v. 1, jun. 2000.

A insurreição do uso. In. José de Souza Martins (org). Henri Lefebvre e o retorno à dialética. São Paulo: Hucitec, 1996. 
SCIFONI, S. O patrimônio como negócio. In. Ana Fani Alessandri Carlos, Danilo Volochko, Isabel Pinto Alvarez (orgs). A cidade como negócio. São Paulo: Contexto, 2015.

SILVA, L. G.; SILVA, G. S.; KROLL, V. A importância da luta em defesa da moradia digna nas regiões centrais e as conquistas através da organização popular. In. São Paulo (SP). Defensoria Pública do Estado de São Paulo. I Jornada em Defesa da Moradia Digna / Defensoria Pública do Estado de São Paulo. - 1. ed. - São Paulo: Defensoria Pública do Estado de São Paulo, 2008.

SINGER, Paul. Economia política da urbanização. $6^{\text {a }}$ edição. São Paulo: Editora brasiliense, 1979.

SMITH, N. A gentrificação generalizada: de uma anomalia local à "regeneração" urbana como estratégia urbana global. In. De volta à cidade: dos processos de gentrificação às políticas de "revitalização" dos centros urbanos. Catherine Bidou-Zachariasen (org.). São Paulo, Annablume, 2006.

El redimensionamiento de las ciudades: la globalización y el urbanismo neoliberal. In: HARVEY; D.; SMITH, N. (Ed.). Capital financiero, propiedad inmobiliaria y cultura. Barcelona: Universitat Autònoma de Barcelona, 2005. p. 59-78. Acessado em Fevereiro de 2015. Disponível em:

http://www.macba.cat/uploads/publicacions/contratextos/capital_financiero/Capital_financiero_neilSmith.pdf

SOARES, L. S. O fio de Ariadne e o desatar dos nós do turismo urbano. In. In. Ana Fani Alessandri Carlos, Danilo Volochko, Isabel Pinto Alvarez (orgs). A cidade como negócio. São Paulo: Contexto, 2015.

SOMBINI, E. A. W. A revalorização contemporânea do Centro de São Paulo: agentes, concepções e instrumentos da urbanização corporativa (2005 - 2012). 2013. 226f. Orientadora: Prof. ${ }^{a}$ Dr. $^{\text {a }}$ Adriana Maria Aparecida Bernardes. Dissertação (Mestrado em Geografia - Análise ambiental e dinâmica territorial). Programa de Pós-Graduação em Geografia do Instituto de Geociências. Universidade Estadual de Campinas. Campinas.

SOUZA, F. F. Um olhar crítico sobre a concessão urbanística em São Paulo: formulação pelo executivo, audiências públicas e regulamentação pelo legislativo. 143f. 2010. Dissertação (Mestrado em Administração Pública e Governo) Orientadora: Marta Ferreira 
Santos Farah - Escola de Administração de Empresas de São Paulo da Fundação Getúlio Vergas - EAESP.

TASCHNER, S. P. Favelas do município de São Paulo: resultados de pesquisa. In. A luta pelo espaço: textos de sociologia urbana. Eva Alterman Blay (organizadora). Petrópolis, RJ: Editora Vozes, 1979.

TAVARES, Maria da Conceição. Acumulação de capital e industrialização no Brasil. Campinas: Editora da UNICAMP, 1985. (FEA, 338. 981 T231a; p. 58, 100 [expansão da industrialização], 101 [ação do Estado], 102, 103 e 104 [industrialização restringida], 108, 112.

TOURINHO, A. O. Do Centro aos centros: bastes teórico-conceituais para o estudo da centralidade em São Paulo. 2001. 438f. Orientadora: Prof. ${ }^{a}$ Dr. ${ }^{a}$ Maria Irene Szmrecsanyi. Tese (Doutorado em Estruturas Ambientais Urbanas). Faculdade de Arquitetura e Urbanismo. Universidade de São Paulo. São Paulo.

VALDOSKI, F. A luta pelo espaço: da segurança da posse à política de regularização fundiária de interesse social em São Paulo. 2012. 370f. Orientadora: Prof. ${ }^{a}$ Dr. ${ }^{a}$ Ana Fani Alessandri Carlos. Tese (Doutorado em Geografia Humana) - Faculdade de Filosofia, Letras e Ciências Humanas. Universidade de São Paulo. São Paulo.

VAN WILDERODE, Daniel J. Desregulamentação urbana. As Operações Interligadas. 1994. 230f. Orientador: Khaled Ghoubar. Dissertação (Mestrado) - Faculdade de Arquitetura e Urbanismo, Universidade de São Paulo, São Paulo.

Vários autores. São Paulo1975: crescimento e pobreza. Estudo realizado para a pontifícia Comissão de Justiça e Paz da Arquidiocese de São Paulo. São Paulo: Edições Loyola, 1982.

VAZ, A. O projeto nova luz e a renovação urbana na região da nova Luz: o espaço urbano como condição e produto da acumulação e como espaço de reprodução da vida. 138f. 2009. Dissertação (Mestrado em Geografia Humana) Orientadora: Prof. ${ }^{a}$ Dr. $^{a}$ Glória Anunciação Alves - Faculdade de Filosofia, Letras e Ciências Humanas, Universidade de São Paulo.

VIANA, L. H. V. A influência do banco interamericano de desenvolvimento na formulação de políticas públicas: análise de financiamento do Programa de Reabilitação da Área Central no Município de SÃO Paulo - PROCENTRO. 2009. 91f. Orientador: 
Fernando Luís Abrucio. Dissertação (mestrado) - Escola de Administração de Empresas de São Paulo. Fundação Getúlio Vargas. São Paulo.

ZMITROWICZ, W.; BORGHETTI, G. Avenidas 1950 - 2000: 50 anos de Planejamento da

Cidade de São Paulo. São Paulo: Editora da Universidade de São Paulo.

\section{Bibliografia Consultada}

BRESSER-PEREIRA, L. C. Reforma da nova gestão pública: agora na agenda da américa latina, no entanto... Revista do Serviço Público/Fundação Escola Nacional de Administração Pública — v.1, n.1 (nov. 1937) - Ano 53, n.2 (Abr-Jun/2002). Brasília: ENAP, 1937.

A reforma gerencial do Estado de 1995. Revista de Administração Pública

34(4), julho 2000: 55-72.

ALTHUSSER, L. Sobre a reprodução. Petrópolis, RJ: Vozes, 2008.

ANTUNES, R. Adeus ao trabalho?: ensaio sobre as metamorfoses e a centralidade do mundo do trabalho. 16. ed. São Paulo: Cortez, 2015.

COLVERO, A. A. A requalificação do centro antigo da cidade de São Paulo: políticas urbanas, planejamento participativo e gestão, no período de 2001-2004. 2010. 168f. Orientadora: Prof. ${ }^{a}$ Dr. ${ }^{a}$ Claudete de Castro Silva Vitte. Dissertação (Mestrado em Geografia Análise ambiental e dinâmica territorial). Programa de Pós-Graduação em Geografia do Instituto de Geociências. Universidade Estadual de Campinas. Campinas.

ENGELS, F. Contribuição ao problema da habitação. Obras escolhidas. Volume 2. Rio de Janeiro: Editorial Vitória, 1961.

FIX, M. Financeirização e transformações recentes no circuito imobiliário do Brasil. 2011. 263f. Orientador: Wilson Cano. Tese (Doutorado) - Instituto de Economia. Universidade Estadual de Campinas, Campinas, SP.

GONÇALVES, M. F. Novas configurações no desenvolvimento paulista. Espaço e Debates. Revista de Estudos Regionais e Urbanos. São Paulo. Ano XIV - 1994 - nº 38. 
HALL, P. Cidades do amanhã: uma história intelectual do planejamento e do projeto urbano no século XX. 2. ed. São Paulo: Perspectiva, 2011.

JURUÁ, C. V. Reforma do Estado: instituições e governança. (2005) Disponível em: http://www.fazenda.pr.gov.br/arquivos/File/Educacao_Fiscal/02_-_Reforma_do_Estado.pdf . Acessado em Maio de 2015.

LEFEBVRE, H. A vida cotidiana no mundo moderno. São Paulo: Ática, 1991.

Introdução à modernidade. Rio de Janeiro: Paz e Terra, 1969.

Posição: contra os tecnocratas. São Paulo: Editora Documentos, 1969a.

LEFÈVRE, R. Notas sobre o papel dos preços de terrenos em negócios imobiliários de apartamentos e escritórios, na cidade de São Paulo. In. Ermínia Maricato. A produção capitalista da casa (e da cidade) no Brasil industrial. São Paulo: Editora Alfa-Ômega, 1982.

LEIRNER, Andre Isai. Divisão de poder e autoridade civil: governança, políticas públicas e desenvolvimento local em projetos fomentados por agências multilaterais. 2006. 203f. Orientador: Mário Aquino Alves. Dissertação (mestrado) - Escola de Administração de Empresas de São Paulo. Fundação Getúlio Vargas. São Paulo.

LUXEMBRUGO, R. Acumulação de capital: estudo sobre a interpretação econômica do imperialismo. Rio de Janeiro: Zahar Editores, 1970.

OSÓRIO, J. O Estado no centro da mundialização: a sociedade civil e o tema do poder. São Paulo: Outras Expressões, 2014.

PACHUKANIS, E. B. Teoria Geral do Direito e Marxismo. São Paulo: Editora Acadêmica, 1988.

PEZOTI, R. H. O projeto Nova Luz e a participação dos sujeitos coletivos e políticos: um processo de reurbanização em questão. 2012. 228f. Orientadora: Prof. ${ }^{a}$ Dr. ${ }^{a}$ Maria Lucia Carvalho de Silva. Tese (Doutorado em Serviço Social). Pontifícia Universidade Católica de São Paulo. São Paulo.

SANFELICI, D. A metrópole sob o ritmo das finanças: implicações socioespaciais da expansão imobiliária no Brasil. 2013. 308f. Orientadora: Prof. ${ }^{a}$ Dr. ${ }^{a}$ Amélia Luísa Damiani. 
Tese (Doutorado em Geografia Humana) - Faculdade de Filosofia, Letras e Ciências Humanas. Universidade de São Paulo. São Paulo.

\section{LEIS E DECRETOS}

BRASIL. Constituição (1988). Capítulo II. Da política urbana. In. BRASIL. Estatuto da Cidade (Lei $\mathbf{n}^{0}$ 10. 257, de 10 de Julho de 2001) / obra coletiva de autoria da editora Saraiva com a colaboração de Antonio Luiz de Toledo Pinto, Márcia Cristina Vaz dos Santos Windt e Lívia Céspedes. - São Paulo: Saraiva, 2001.

BRASIL. Decreto n ${ }^{\circ} 8.428$, de 02 de Abril de 2015. Dispõe sobre o Procedimento de Manifestação de Interesse - PMI.

BRASIL. Estatuto da cidade (2002). Estatuto da cidade: guia para implentação pelos municípios e cidadãos : Lei n. 10.257, de 10 de julho de 2001, que estabelece diretrizes gerais da política urbana. - 2. ed. - Brasília : Câmara dos Deputados, Coordenação de Publicações, 2002.

BRASIL. Ministério da Administração Federal e Reforma do Estado. Plano diretor da reforma do aparelho do Estado. Brasília, Imprensa Nacional, 1995.

SÃO PAULO (Município). Decreto no 33.389, de 14 de Julho de 1993. Cria o Programa de Requalificação Urbana e Funcional do Centro de São Paulo - PROCENTRO.

SÃO PAULO (Município). Decreto n ${ }^{\circ} 33.390$, de 14 de Julho de 1993. Cria a comissão do Procentro para atuar no Programa de Requalificação Urbana e Funcional do Centro de São Paulo.

SÃO PAULO (Município). Lei no 14.917 , de 7 maio de 2009. Dispõe sobre a concessão urbanística no município de São Paulo.

SÃO PAULO (Município). Lei no 14.918, de 7 maio de 2009. Autoriza o Executivo a aplicar a concessão urbanística na área da Nova Luz.

SÃO PAUlO (Município). Lei $\mathbf{n}^{\mathbf{0}}$ 16.050, de 31 de Julho de 2014. Aprova a Política de Desenvolvimento Urbano e o Plano Diretor Estratégico do Município de São Paulo e revoga a Lei $n^{\circ} 13.430 / 2002$.

SÃO PAULO (Município). Lei no 40.753 de Junho de 2001. Cria a Coordenadoria de Programas de Reabilitação da Área Central - PROCENTRO.

SÃO PAULO (Múnicípio). Lei orgânica do município de São Paulo (com suas alterações). 
SÃO PAULO (Município). Planta Genérica de Valores. Ano 2010. Acessado em Setembro de 2013. Disponível em: http://www.2hengenharia.com.br/plantagenericadevalores.pdf

\section{DOCUMENTOS}

A cartilha da área central. SP - URBANISMO - Diretoria de Desenvolvimento e Gestão Gerência de Operações Urbanas. 2 ed. revisada. São Paulo, Agosto de 2010.

GOVERNO DO ESTADO DE SÃO PAULO. CHAMAMENTO PÚBLICO N. 004/2012.

GOVERnO DO ESTADO DE SÃO PAUlO. ESTATUTO SOCIAL. Companhia Paulista de Parcerias. Documento atualizado conforme Assembleia Geral Extraordinária de 30/04/2014.

PREFEITURA DE SÃO PAULO. COMUNICADO DE CHAMAMENTO PÚBLICO No 1/2013/SMDU.

PREFEITURA DE SÃO PAULO. PROJETO NOVA LUZ - Estudos de viabilidade econômica, mercadológica e de situação fundiária - consolidados. Subproduto 5.6: Projeto NOVA LUZ, São Paulo, Brasil. Julho de 2011.

PREFEITURA DE SÃO PAULO. Secretaria de Desenvolvimento Urbano. Projeto Urbanístico Específico (PUE). Subproduto 5.1: PUE Consolidado. Projeto NOVA LUZ, São Paulo, Brasil. Julho de 2011.

PREFEITURA MUNICIPAL DE SÃO PAULO, SP-URBANISMO, Metodologia e critérios de aproveitamento de estudos. (sem data).

PREFEITURA MUNICIPAL DE SÃO PAULO. Projeto “Arco do Tietê". Seminário Temático. Registro de reunião: 04/04/2013

PREFEITURA MUNICIPAL DE SÃO PAULO. Projeto “Arco do Tietê". Seminário Temático. Registro de reunião: 26/04/2013.

PREFEITURA MUNICIPAL DE SÃO PAUlO. Turismo no Centro - Plano de Desenvolvimento Turístico do Centro da Cidade de São Paulo. 1a ed. - São Paulo: São Paulo Turismo, 2008. Vários colaboradores. 


\section{ANEXO 01}

A série de gráficos a seguir foi composta com base em três tipos de dados sobre mercado imobiliário na cidade de São Paulo. Considerando o número de lançamentos residenciais verticais, a área total lançada $\left(\mathrm{m}^{2}\right)$ dos lançamentos residenciais verticais, como também a área total lançada $\left(\mathbf{m}^{2}\right)$ dos lançamentos comerciais verticais, o objetivo com os dados foi expor o movimento dos lançamentos ao longo do tempo.

Verifica-se que há uma dinâmica específica para os distritos do Bom Retiro, Brás e Pari, principalmente após o ano de 2005. Alguns distritos como Bela Vista e Consolação tem uma dinâmica que passa por influências significativas dos lançamentos residenciais verticais que ocorrem nas proximidades da Avenida Paulista. A dinâmica no distrito Liberdade não ocorre numa relação de identidade direta com o Centro de São Paulo, contudo, observa-se neste distrito um movimento constante no número de lançamentos desde a década de 1990, porém, que na atualidade passa por um refluxo. No distrito Santa Cecília ocorre algo similar, sendo que o mesmo período de pico de lançamentos também correspondem, entre os anos de 2006 e 2008.

Levando em conta o total dos lançamentos imobiliários em São Paulo neste intervalo de tempo, os anos entre 2004 e 2007 caracterizaram um período de picos que chegaram a um percentual de quase $4 \%$ do total de lançamentos na metrópole. A tendência é que os distritos Bom Retiro, Brás e Pari, conforme forem disponibilizados estoques para construir, continuem a apresentar alguns índices significativos de novos lançamentos, principalmente os residenciais. No que tange aos lançamentos comerciais, os distritos Liberdade e Santa Cecília apresentam uma dinâmica mais acentuada, principalmente após o ano de 2009. Vale lembrar também que é após o ano de 2005 que as estratégias para a revalorização do Centro de São Paulo (principalmente o Projeto "Nova Luz") passa a caracterizar com mais potência a revalorização do Centro de São Paulo e esta nova imagem atrelada aos empreendimentos imobiliários. 
Gráficos referentes à porcentagem de Número de Lançamentos Residenciais Verticais
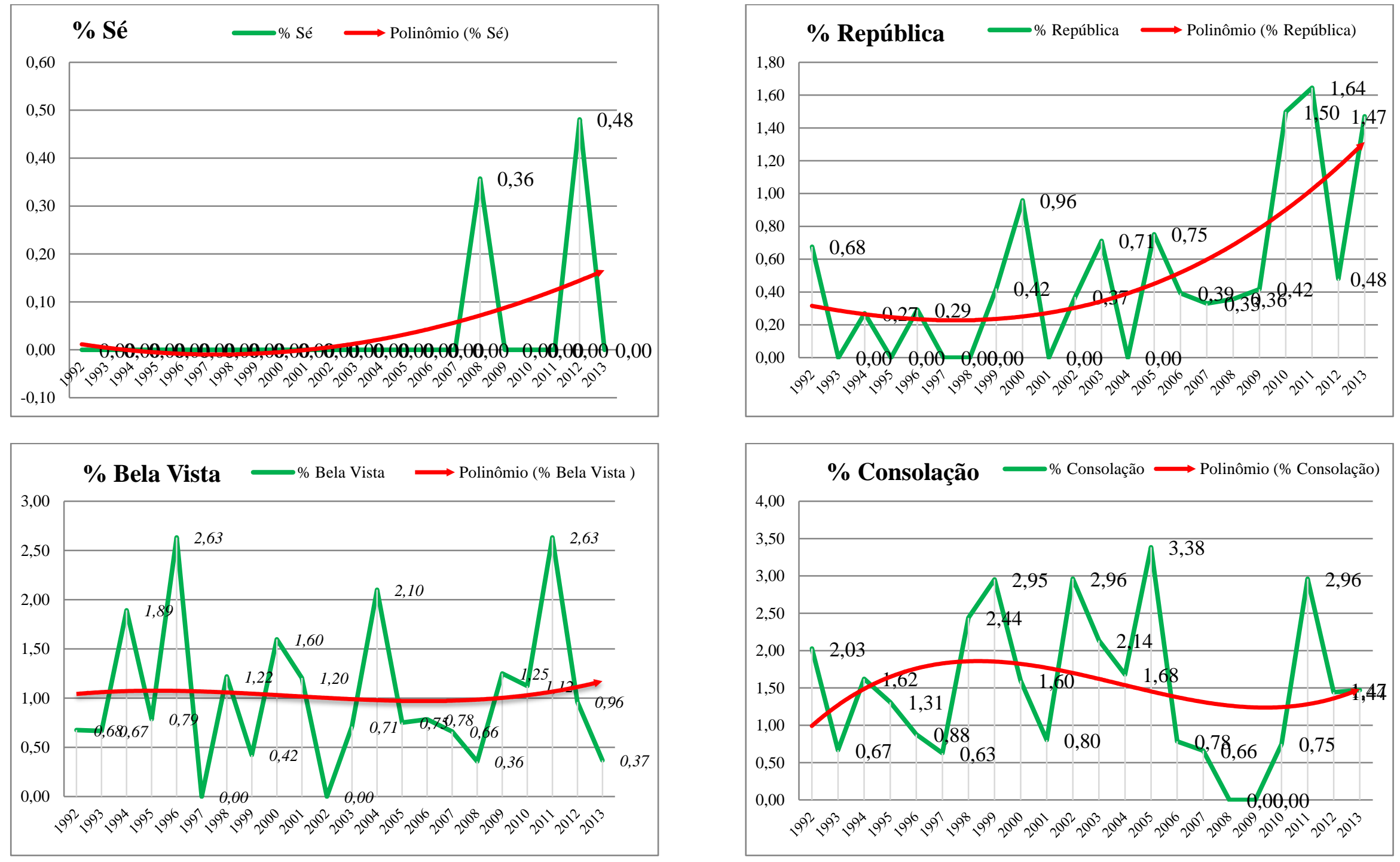

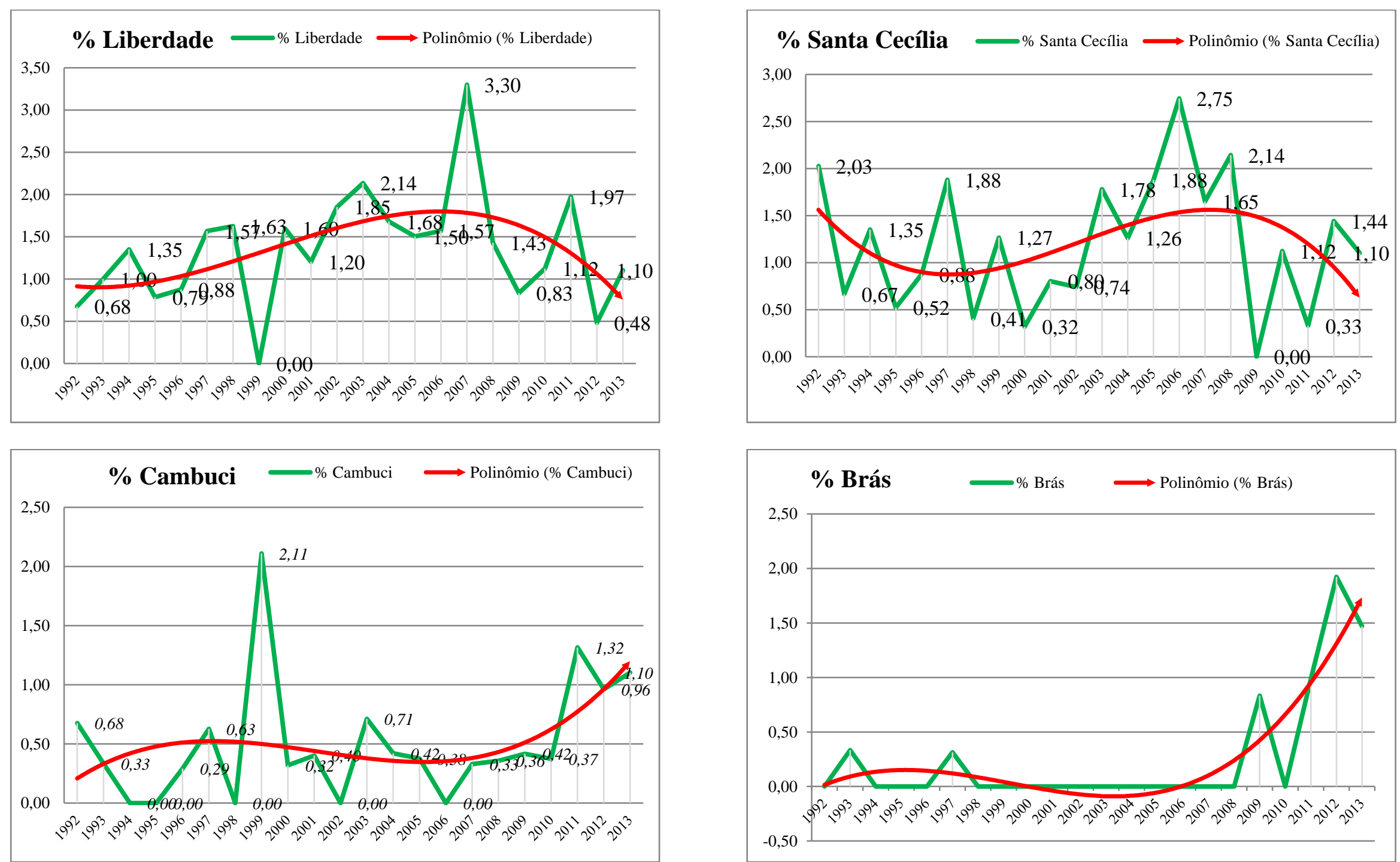

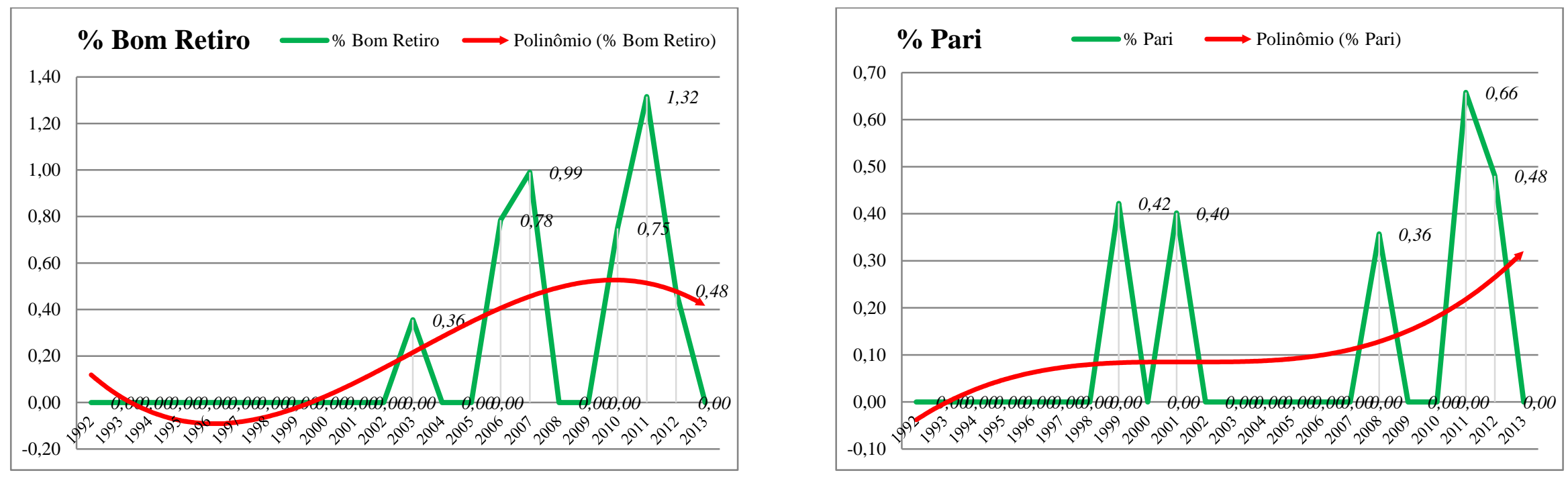

Fonte: Prefeitura Municipal de São Paulo Infocidade - Mercado Imobiliário, tabelas. http://infocidade.prefeitura.sp.gov.br

Método: os dados dispostos em gráficos correspondem à porcentagem de Número de Lançamentos Residenciais Verticais nos respectivos distritos, em relação ao total de lançamentos residenciais verticais no município de São Paulo.

Organização e elaboração: Gilmar Soares, 2015. 
Gráficos referentes à porcentagem de Área Total Lançada $\left(\mathrm{m}^{2}\right)$ dos Lançamentos Comerciais Verticais
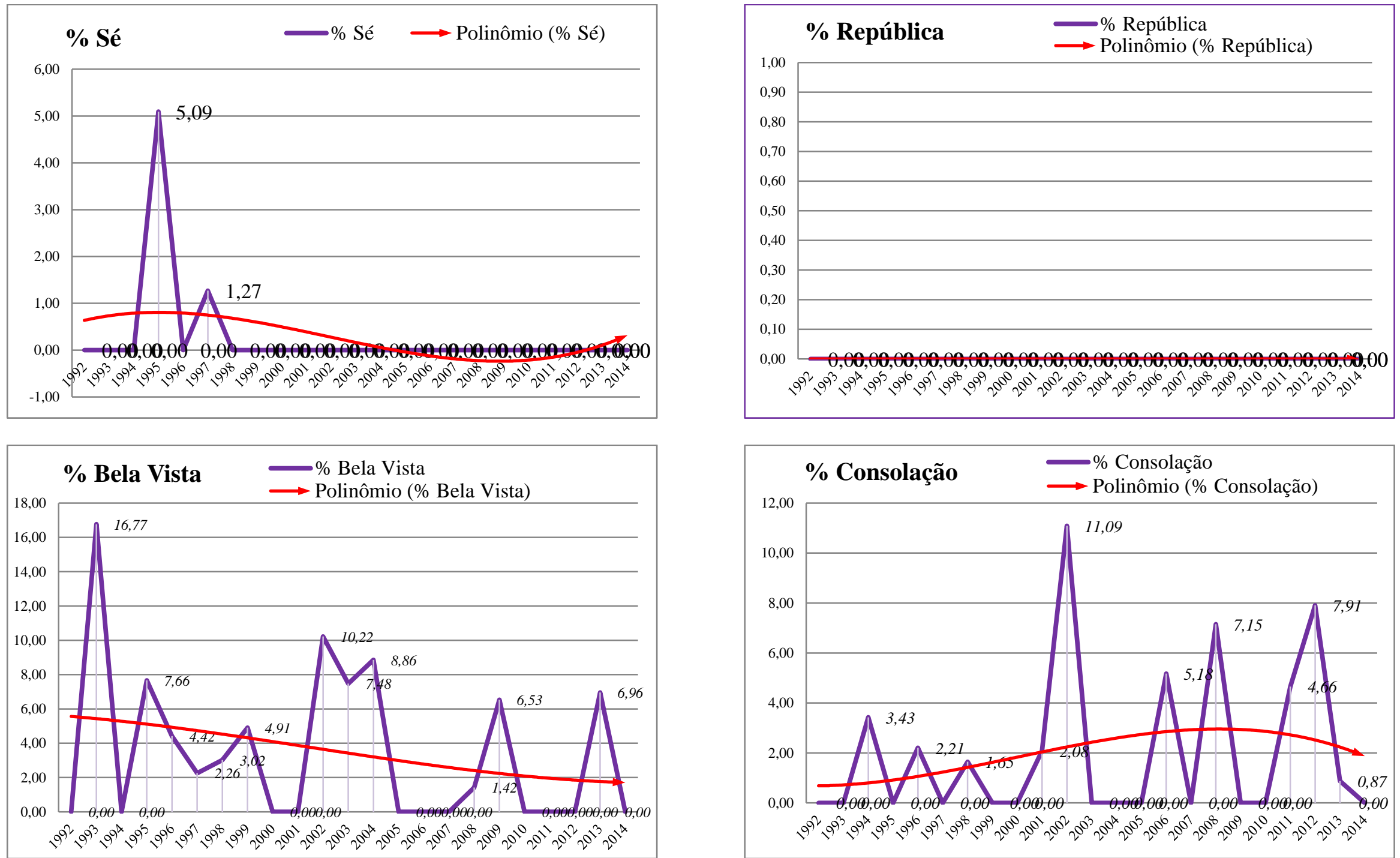

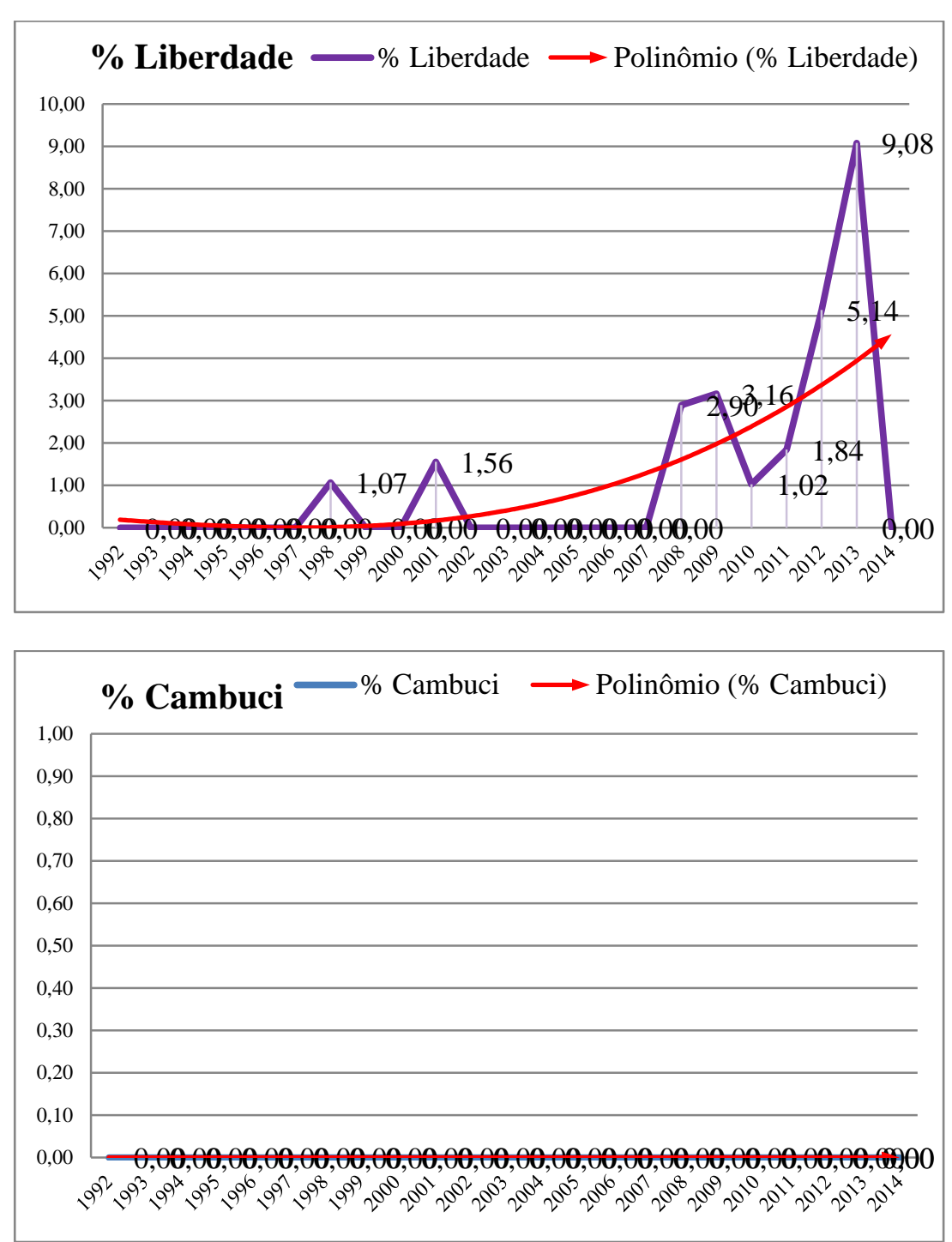
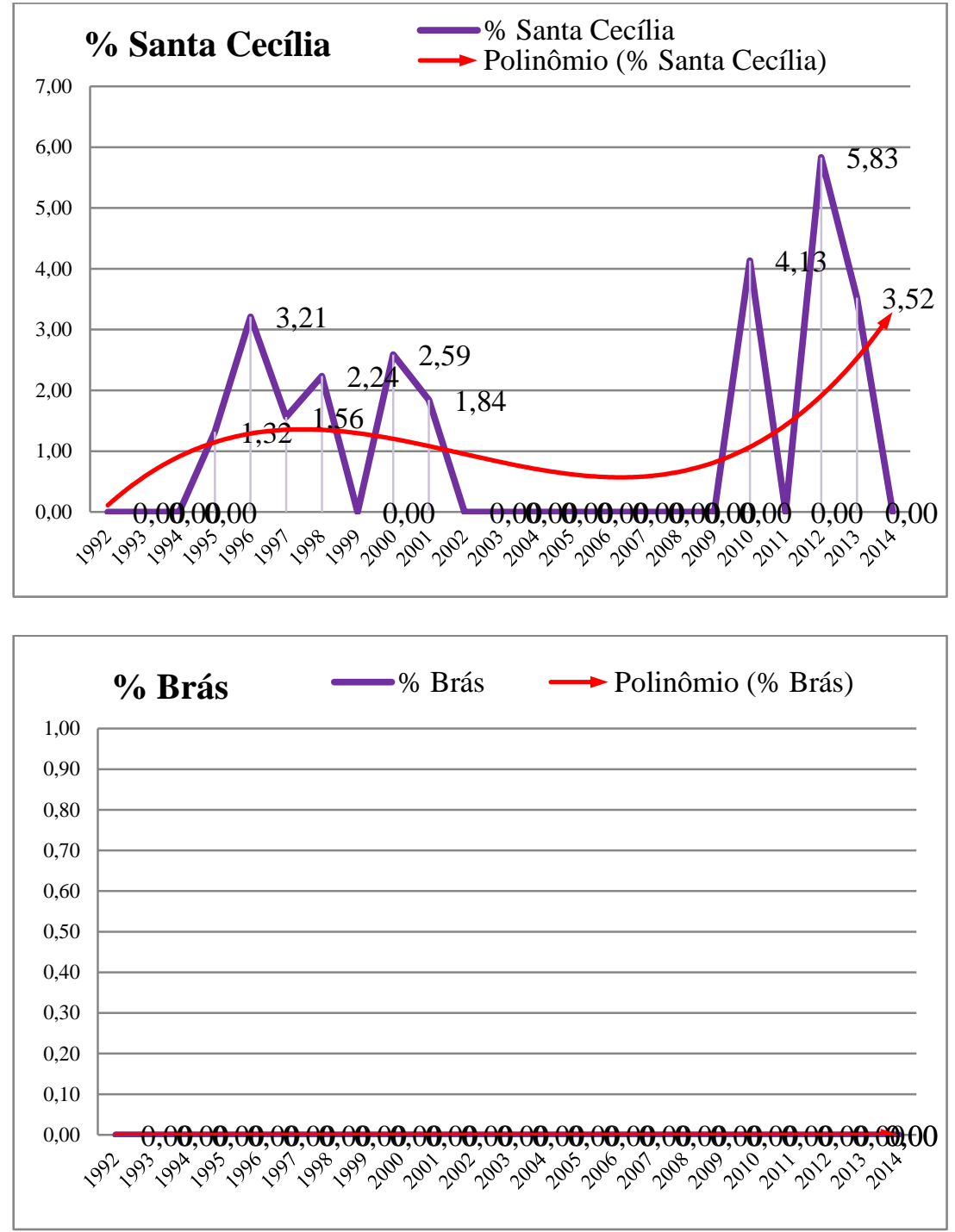

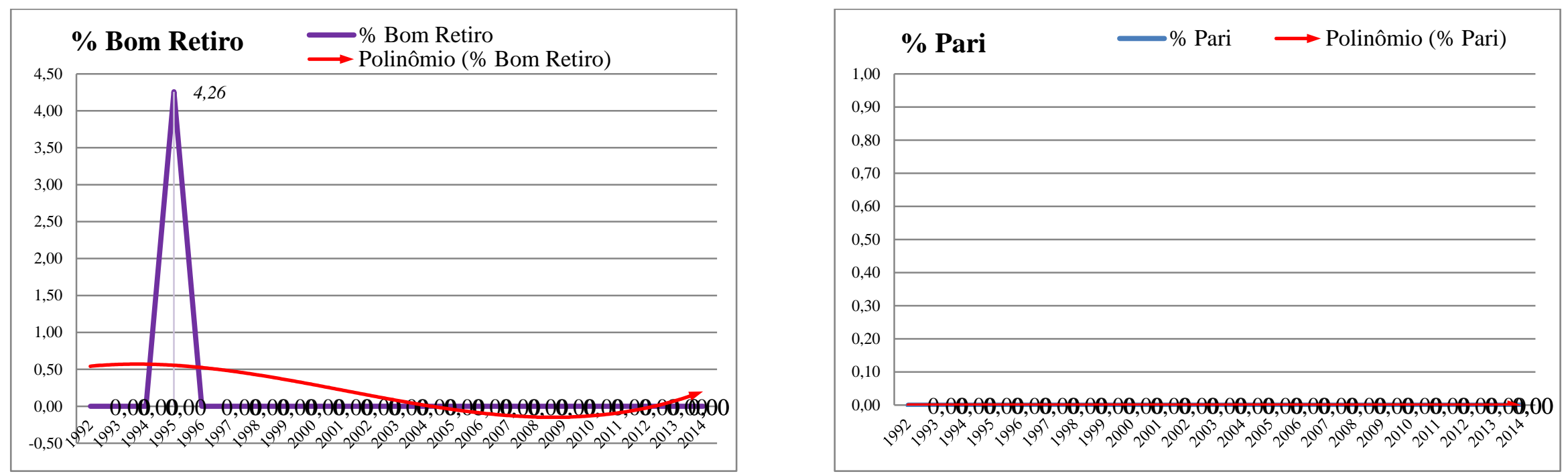

Fonte: Prefeitura Municipal de São Paulo Infocidade - Mercado Imobiliário, tabelas. http://infocidade.prefeitura.sp.gov.br

Método: os dados dispostos em gráficos correspondem à porcentagem de Área Total Lançada $\left(\mathrm{m}^{2}\right)$ dos Lançamentos Comerciais Verticais nos respectivos distritos, em relação ao total de área lançada $\left(\mathrm{m}^{2}\right)$ dos lançamentos comerciais verticais no município de São Paulo.

Organização e elaboração: Gilmar Soares, 2015. 
Gráficos referentes à porcentagem da Área Total Lançada $\left(\mathrm{em} \mathrm{m}^{2}\right)$ dos Lançamentos Residenciais Verticais
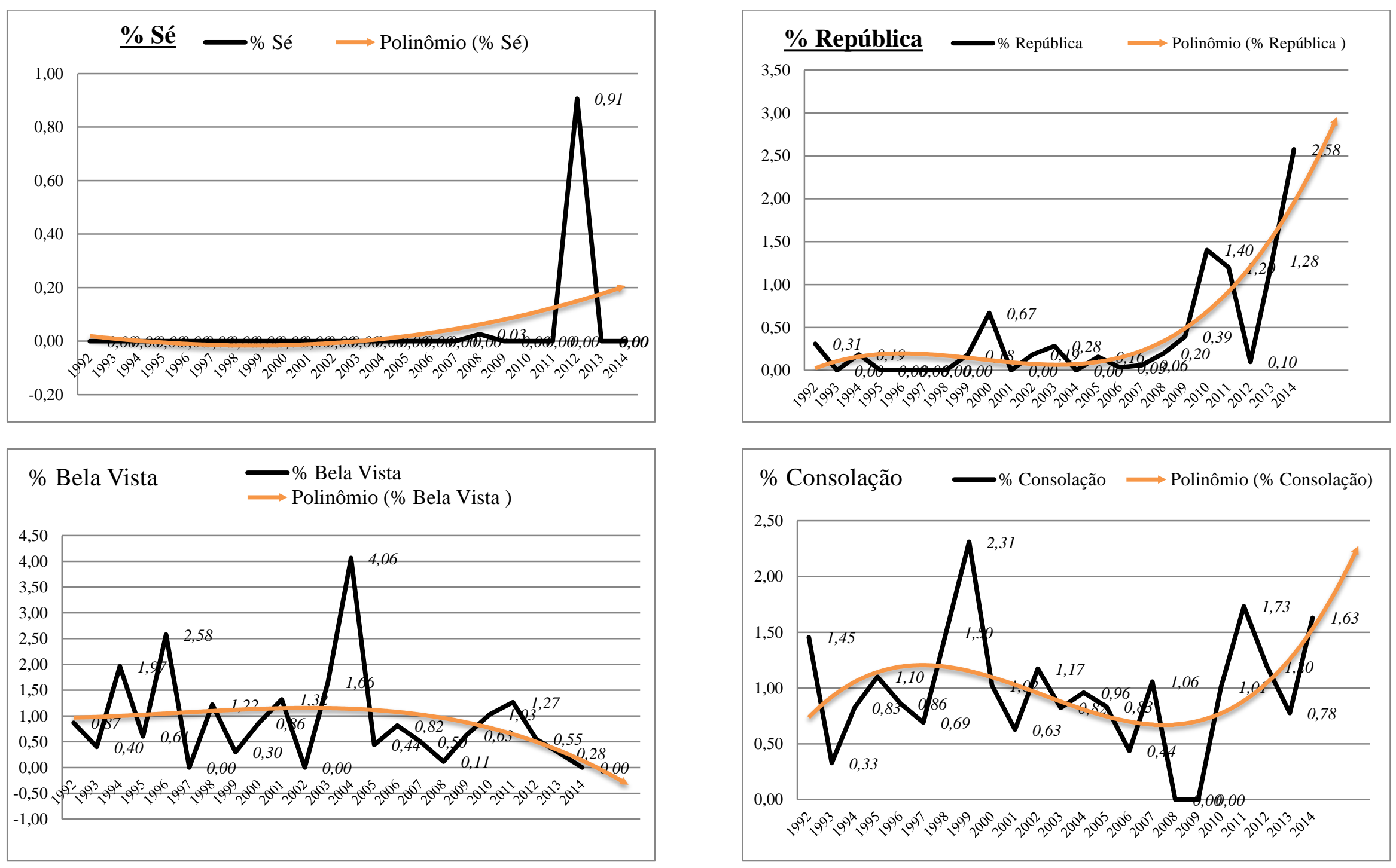

197 

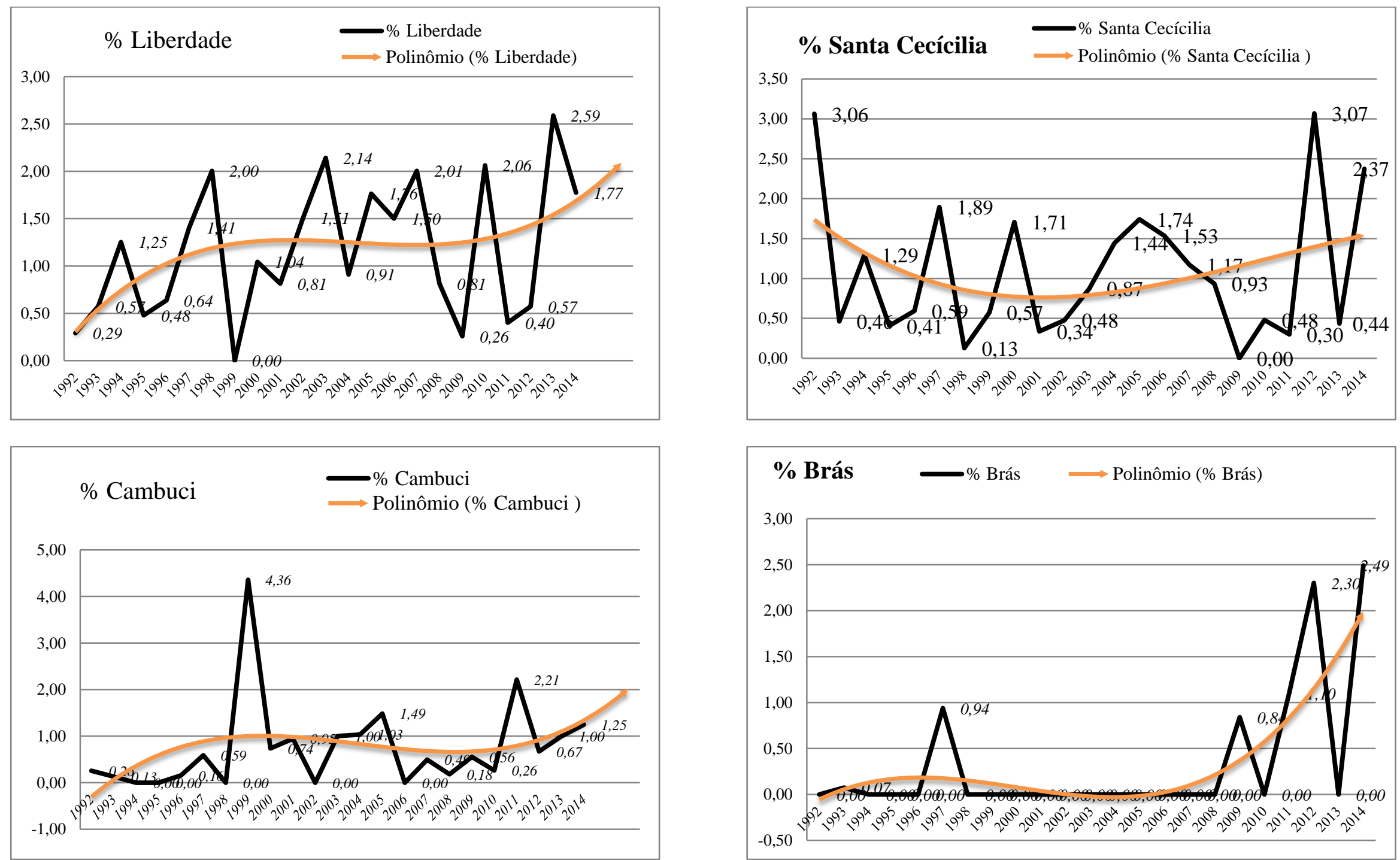

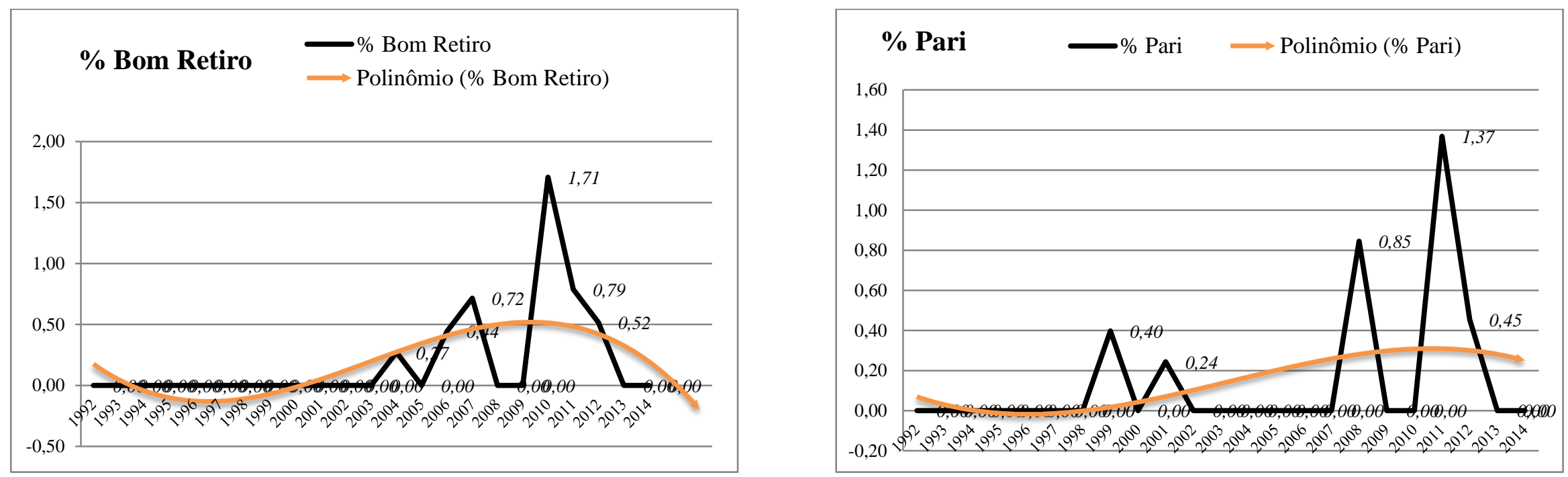

Fonte: Prefeitura Municipal de São Paulo Infocidade - Mercado Imobiliário, tabelas. http://infocidade.prefeitura.sp.gov.br

Método: os dados dispostos em gráficos correspondem à porcentagem da Área Total Lançada $\left(\mathrm{em} \mathrm{m}^{2}\right.$ ) dos Lançamentos Residenciais Verticais nos respectivos distritos, em relação ao total deste tipo de lançamentos no município de São Paulo. 


\section{AnEXo 02}

Variação progressiva dos Preços do metro quadrado para apartamentos residenciais nos distritos (e bairro da Luz) que compõem a área central. A fonte dos dados é do índice FIPE-ZAP. O comparativo dos dados foi feito dos respectivos distritos (e bairro da Luz) com o distrito Sé.

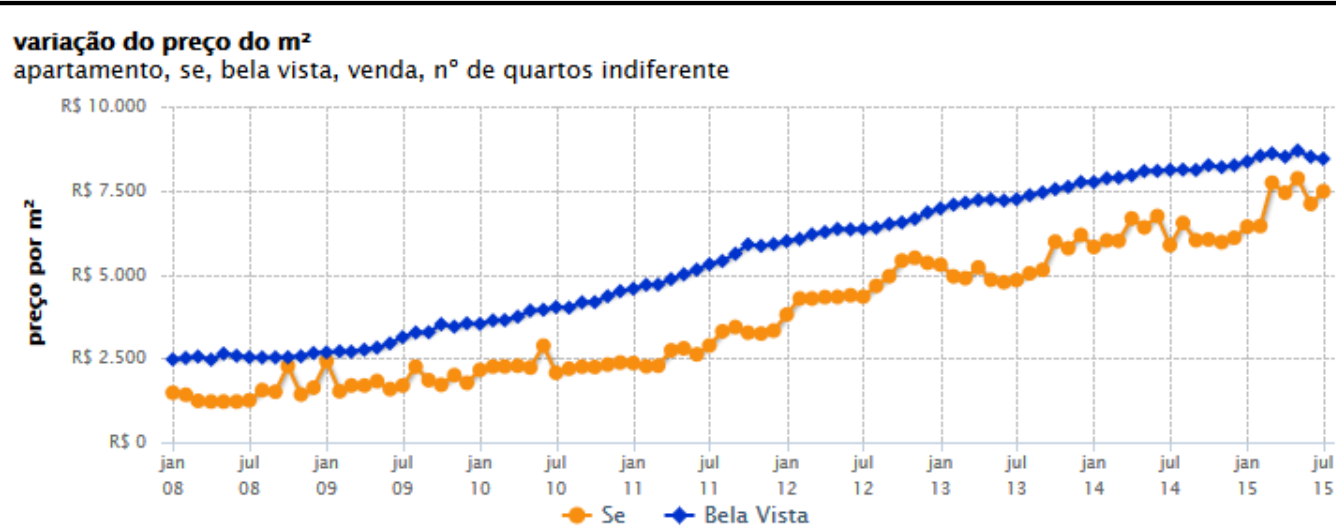

variação do preço do $\mathrm{m}^{2}$

apartamento, se, bom retiro, venda, $\mathrm{n}^{\circ}$ de quartos indiferente

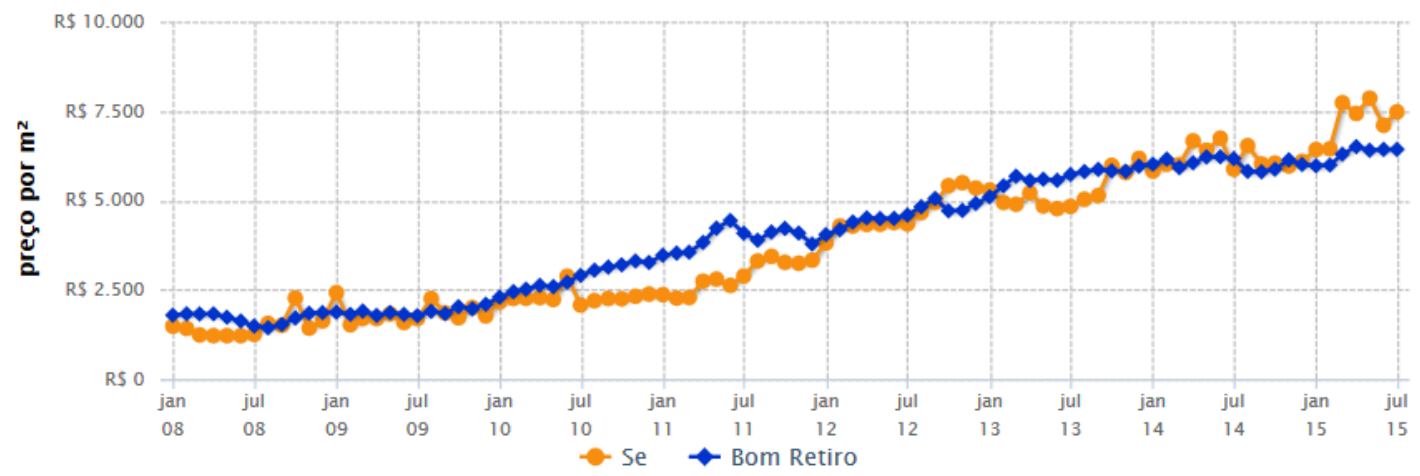


variação do preço do $\mathrm{m}^{\mathbf{2}}$

apartamento, se, bras, venda, $\mathrm{n}^{\circ}$ de quartos indiferente

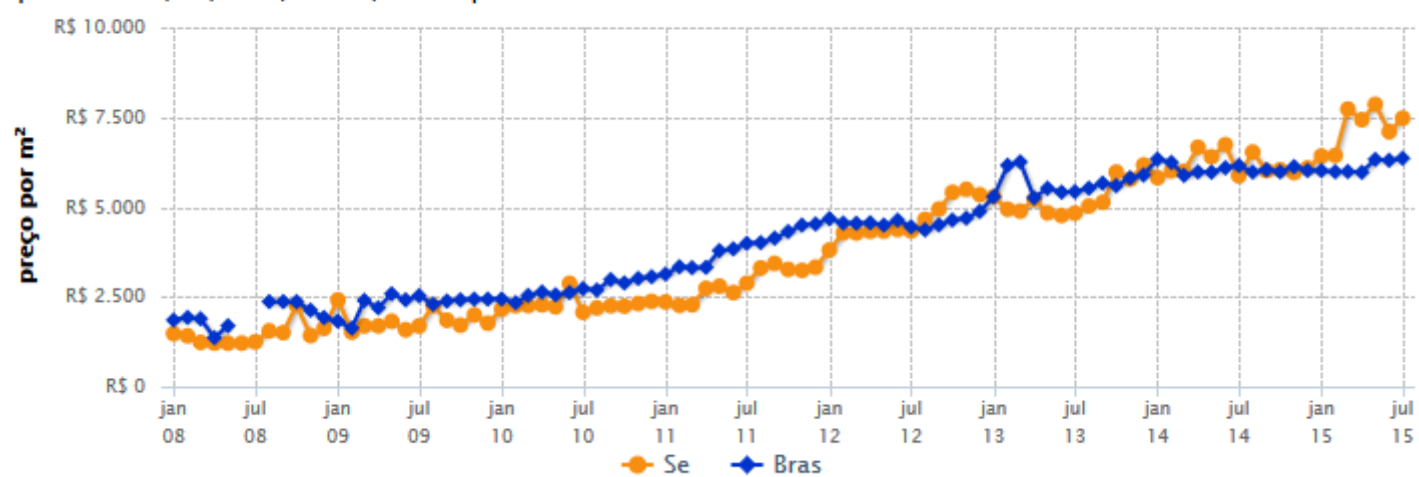

variação do preço do $\mathrm{m}^{2}$

apartamento, se, cambuci, venda, $n^{\circ}$ de quartos indiferente

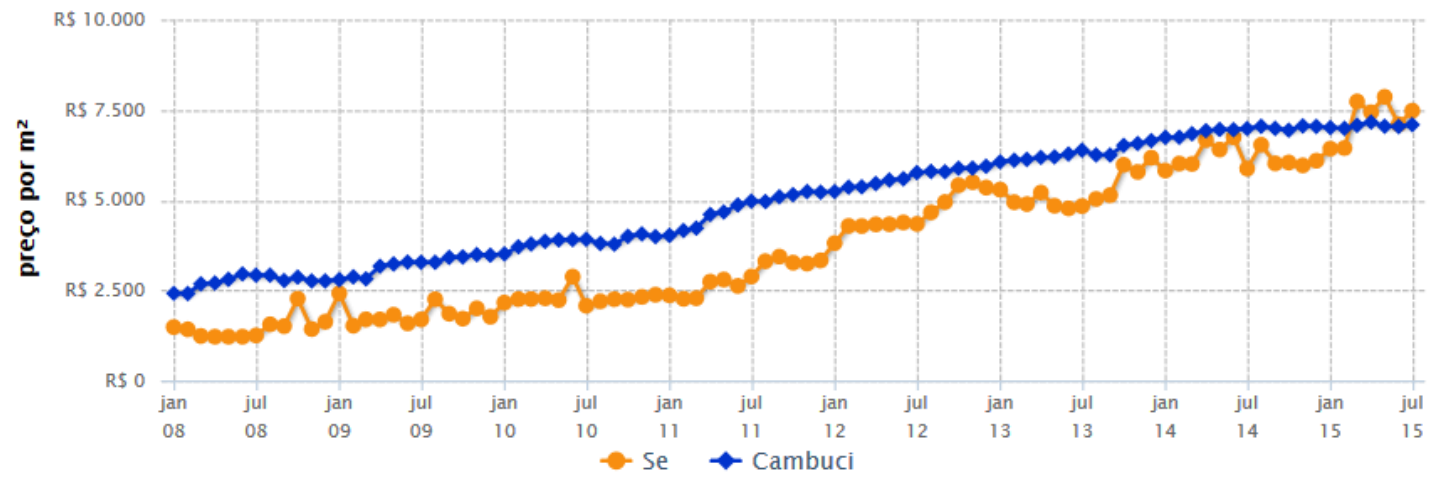

variação do preço do $\mathrm{m}^{2}$

apartamento, se, consolacao, venda, $\mathrm{n}^{\circ}$ de quartos indiferente

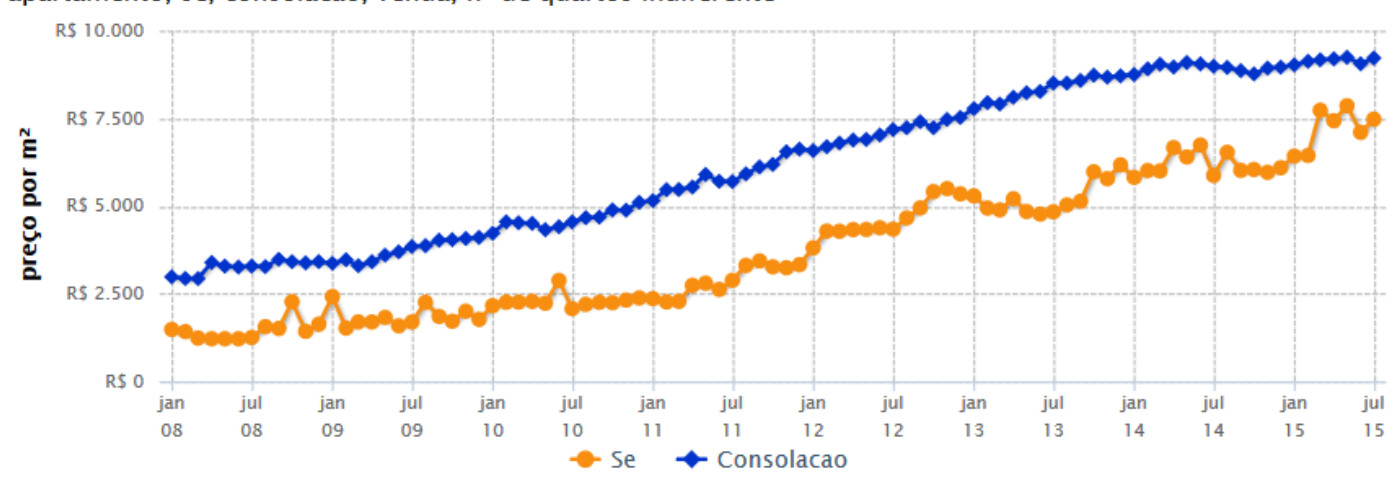


variação do preço do $\mathrm{m}^{2}$

apartamento, se, liberdade, venda, $\mathrm{n}^{\circ}$ de quartos indiferente

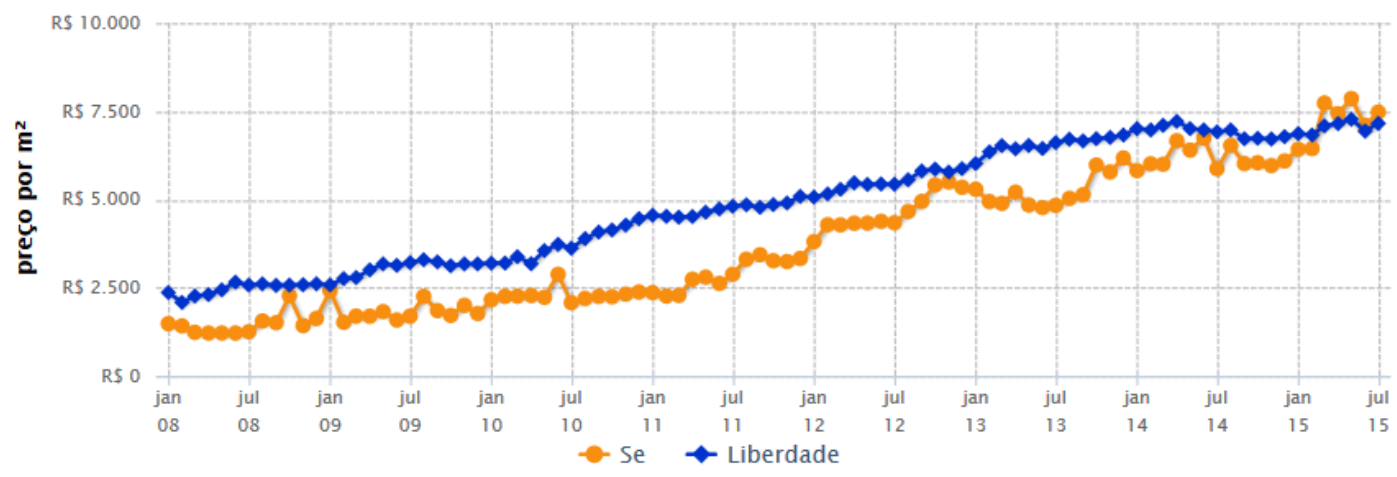

variação do preço do $\mathrm{m}^{2}$

apartamento, se, luz, venda, $\mathrm{n}^{\circ}$ de quartos indiferente

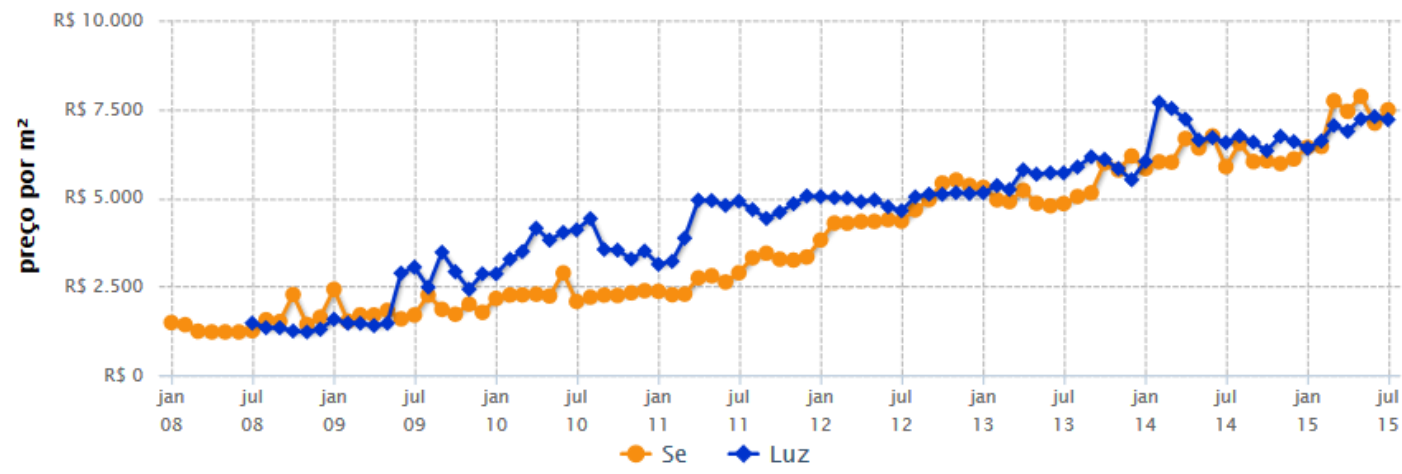

variação do preço do $\mathrm{m}^{2}$

apartamento, se, pari, venda, $\mathrm{n}^{\circ}$ de quartos indiferente

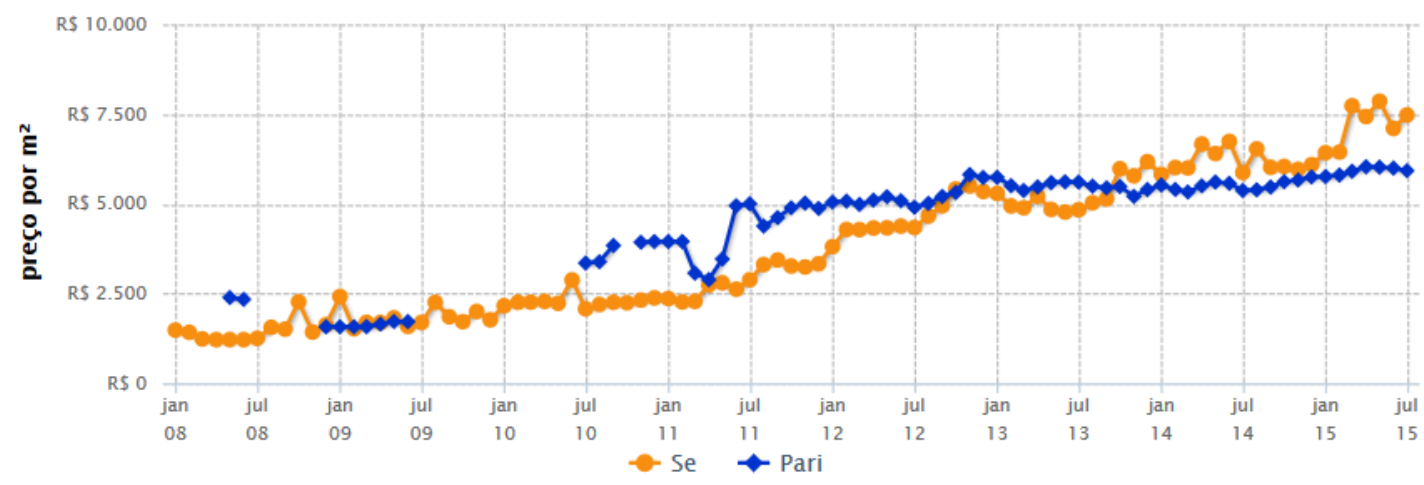


variação do preço do $\mathrm{m}^{2}$

apartamento, se, republica, venda, $\mathrm{n}^{\circ}$ de quartos indiferente

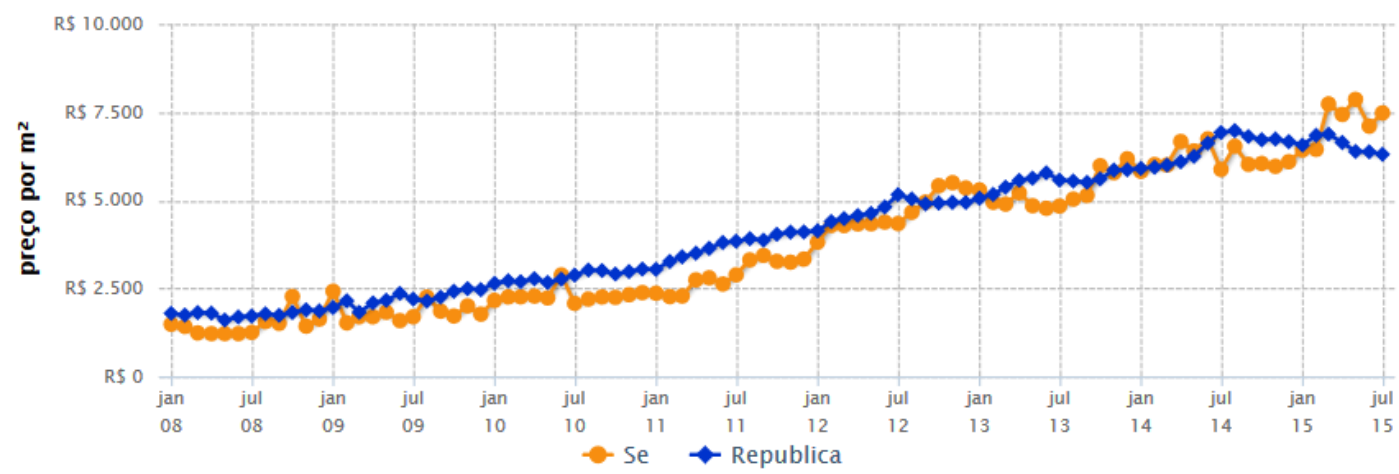

variação do preço do $\mathrm{m}^{2}$

apartamento, se, sta cecilia, venda, $\mathrm{n}^{\circ}$ de quartos indiferente

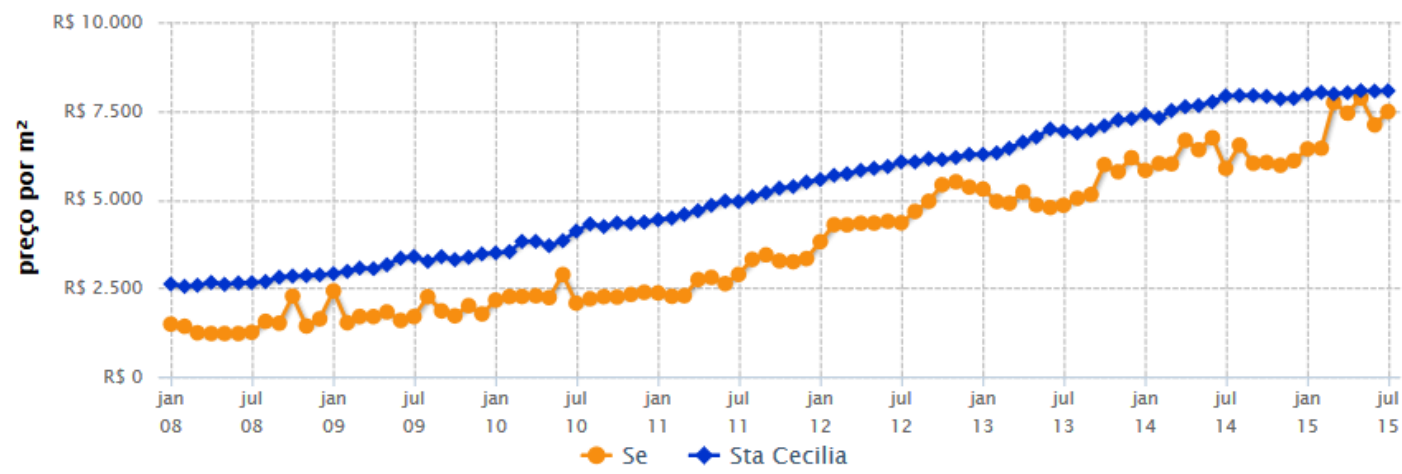




\section{AneXo 03}

Lançamentos residenciais nos distritos contíguos e bairros do Centro de São Paulo.

\section{Distrito do Bom Retiro}
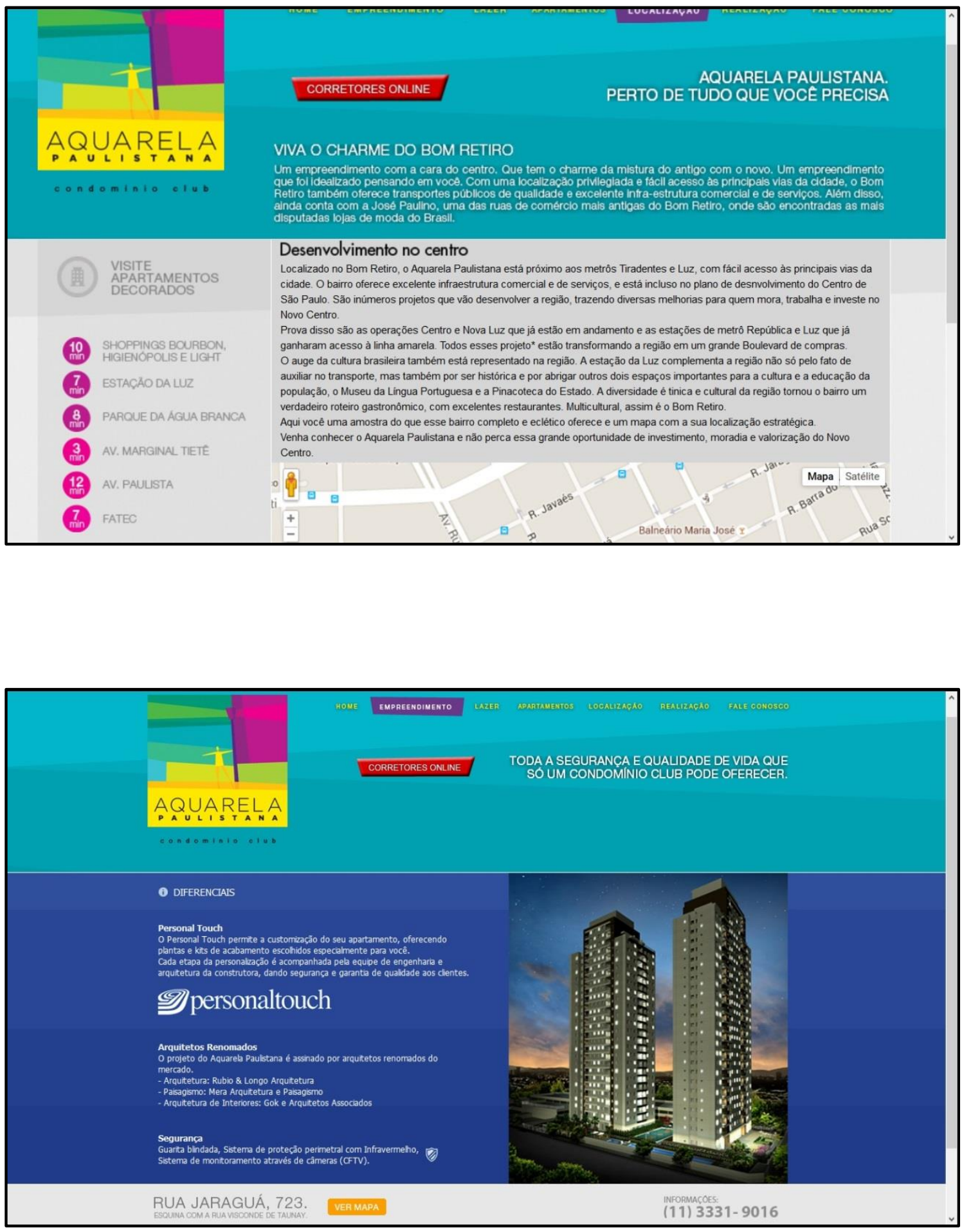


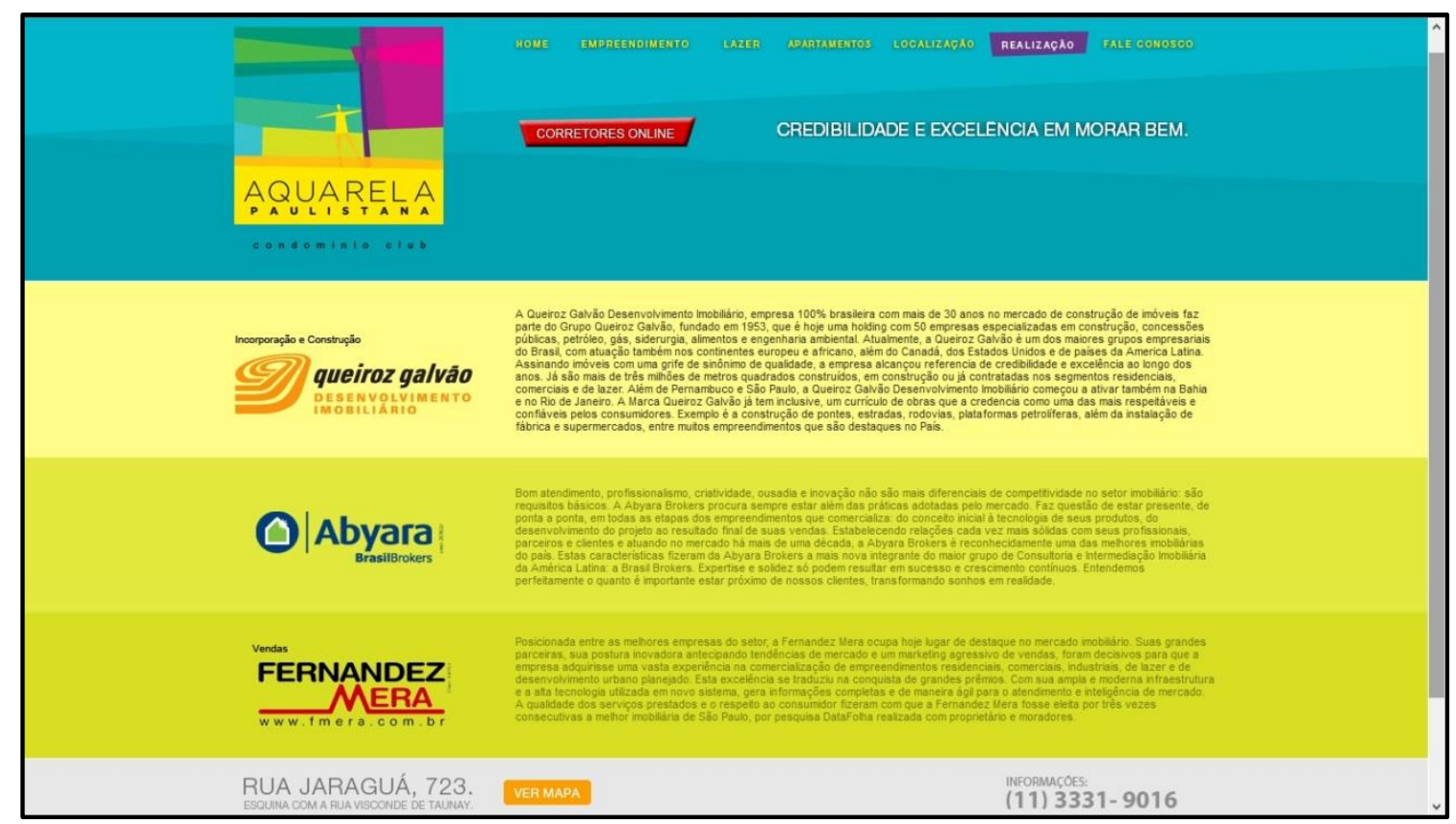

\section{Distrito do Brás}

Empreendimento Brás Clube

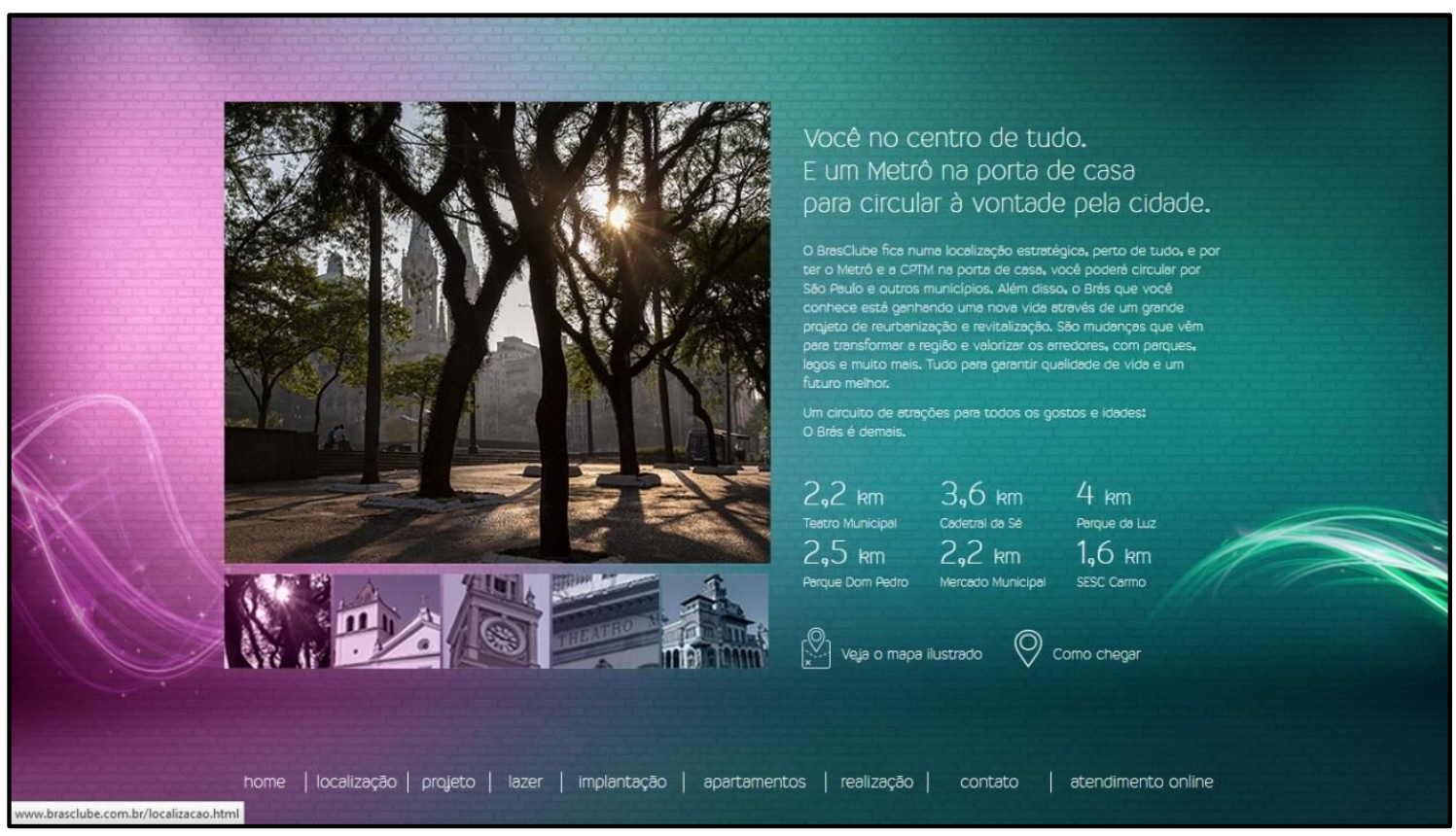




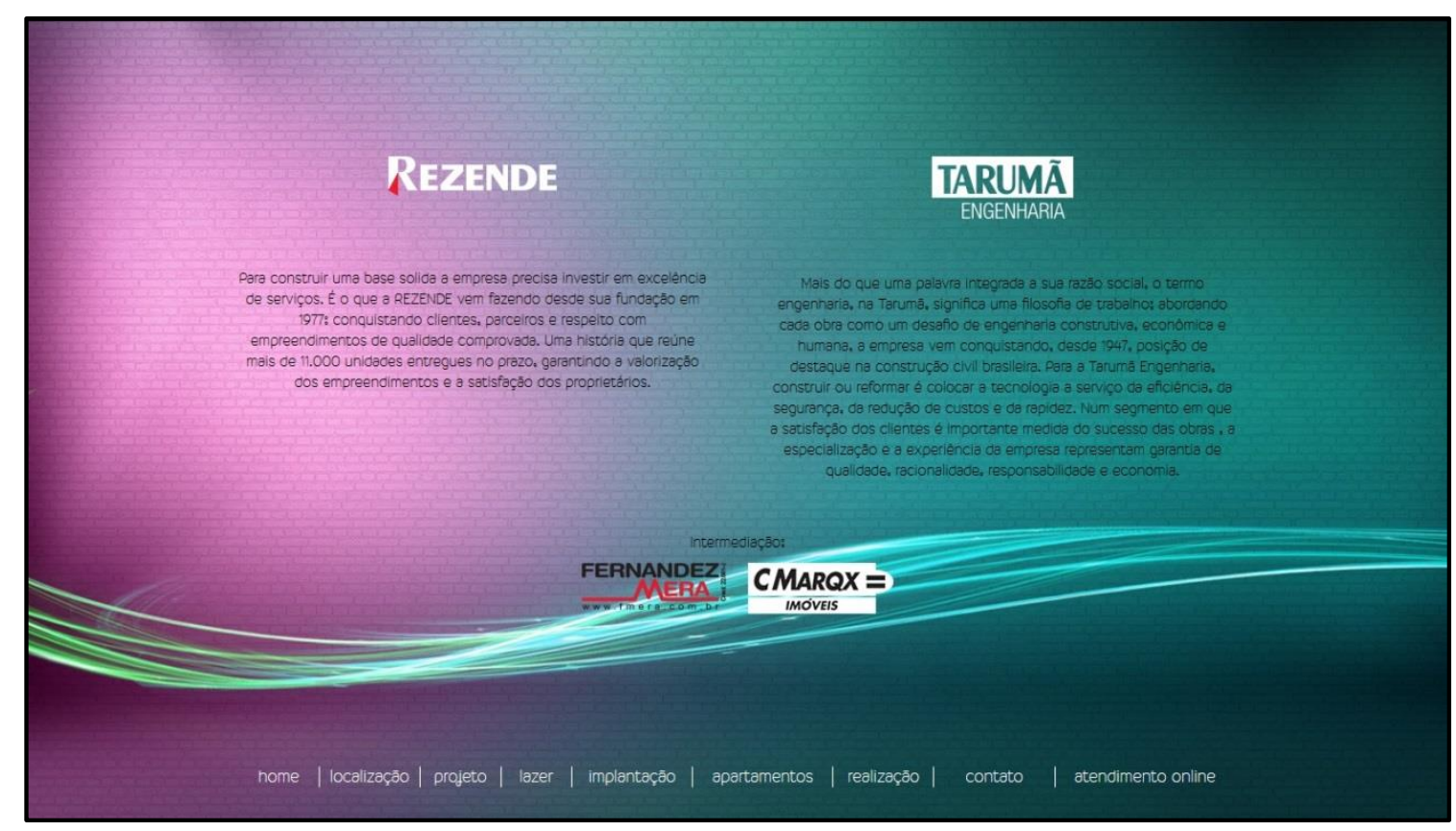

Empreendimento Capital Brás

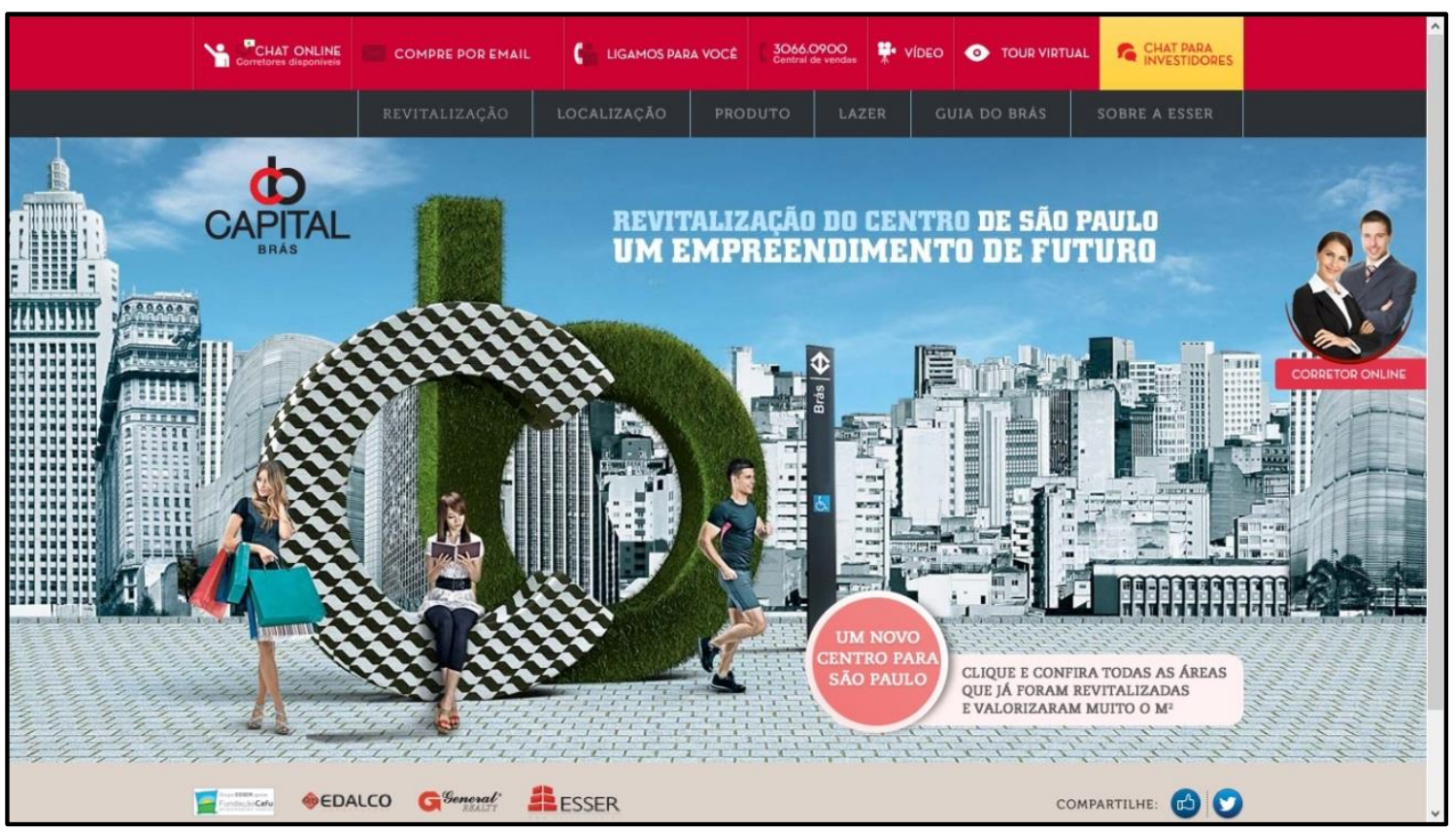



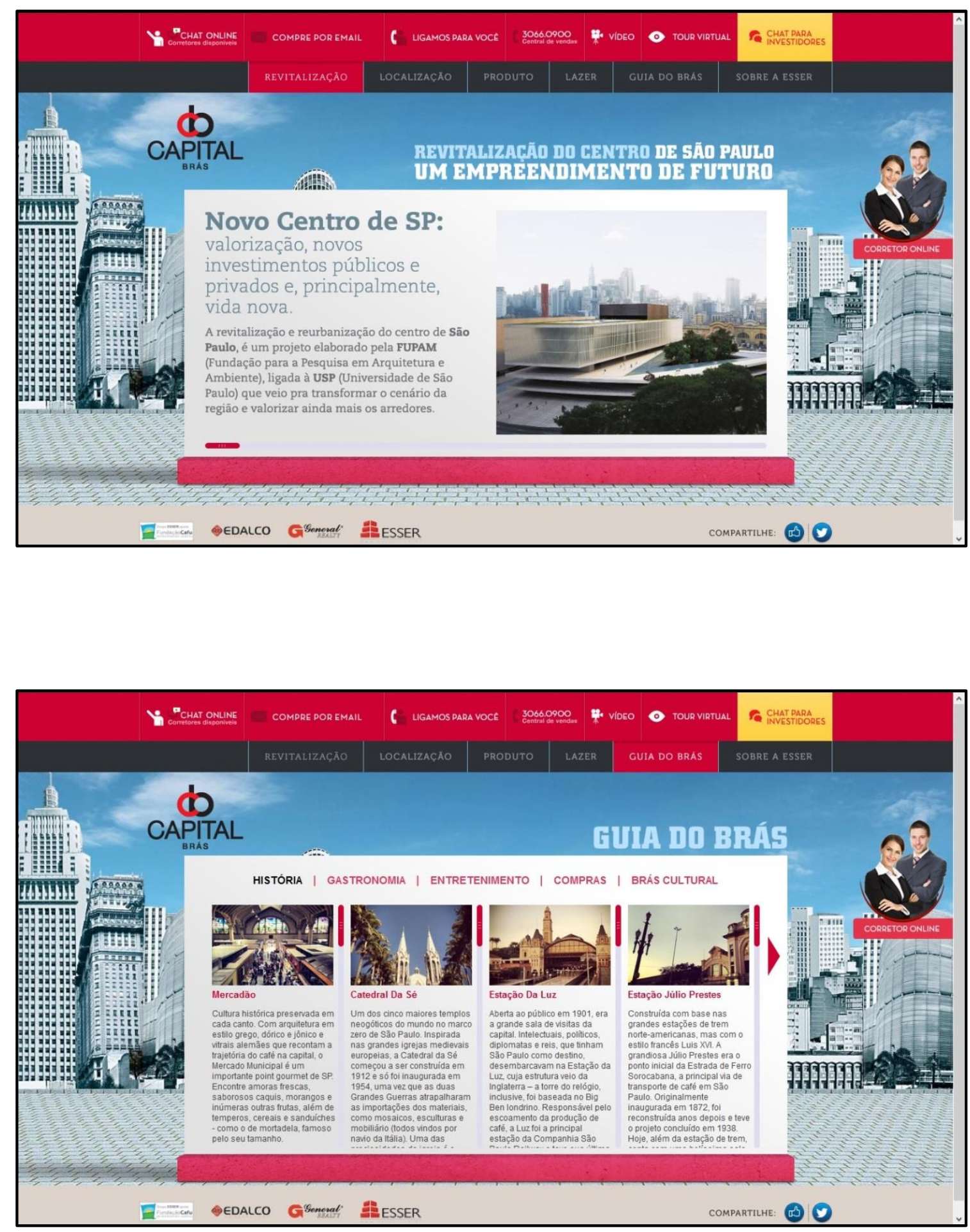


\section{Empreendimento Estação Brás}
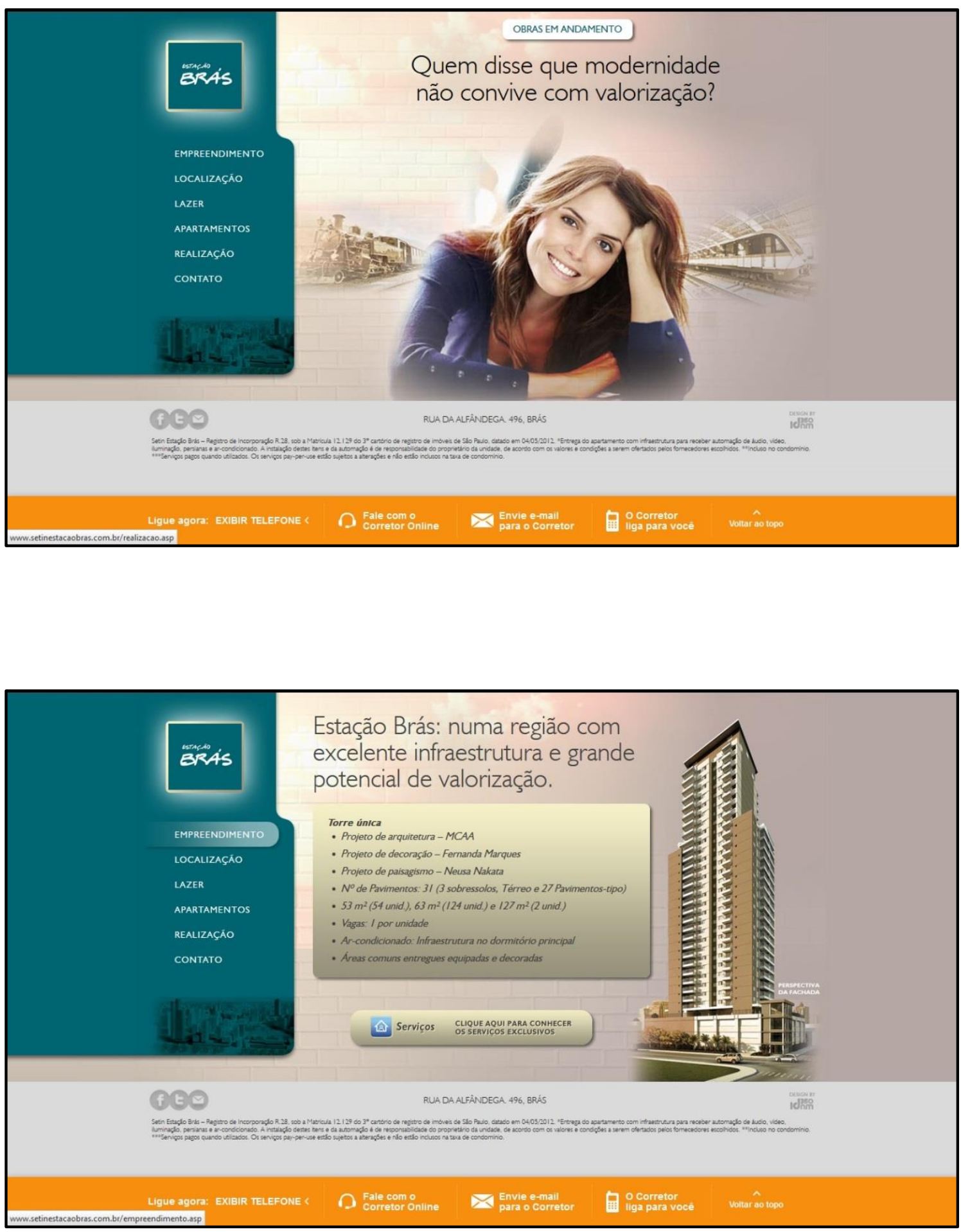


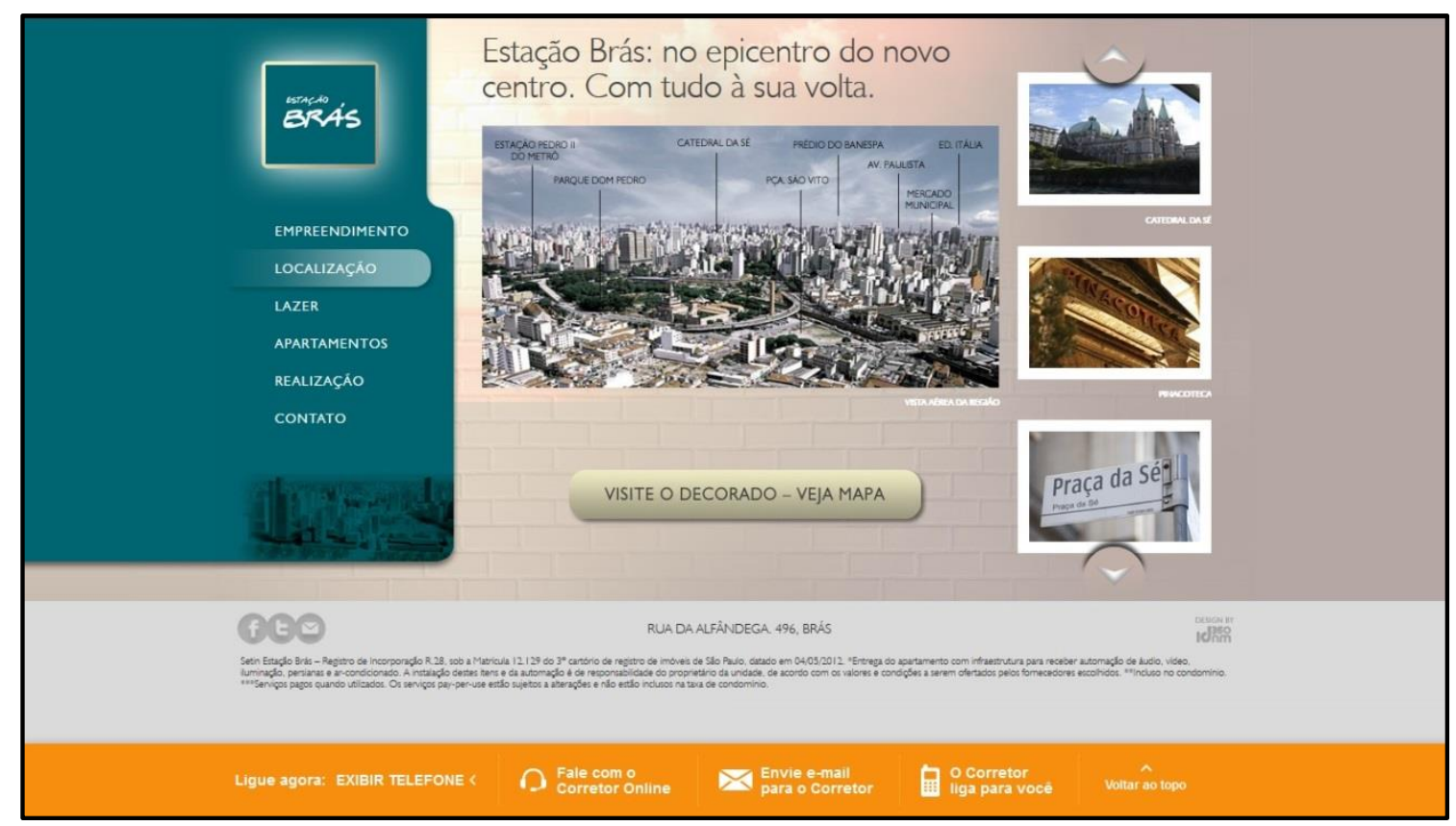

Empreendimento Portal Centro (Even)

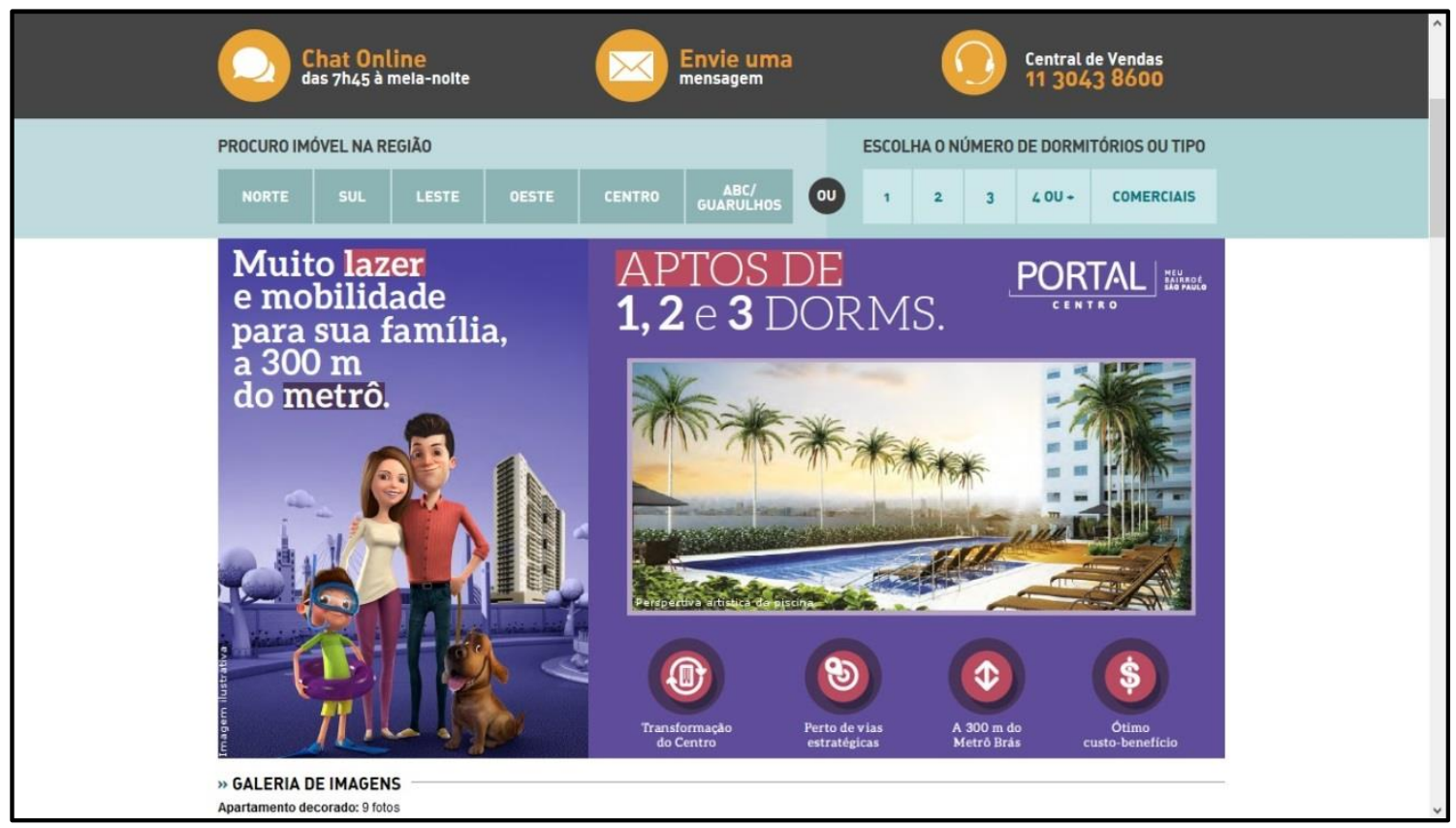


Baixada do Glicério (New Way Brookfield), com estratégias de marketing destinadas à classe média como público alvo do produto.
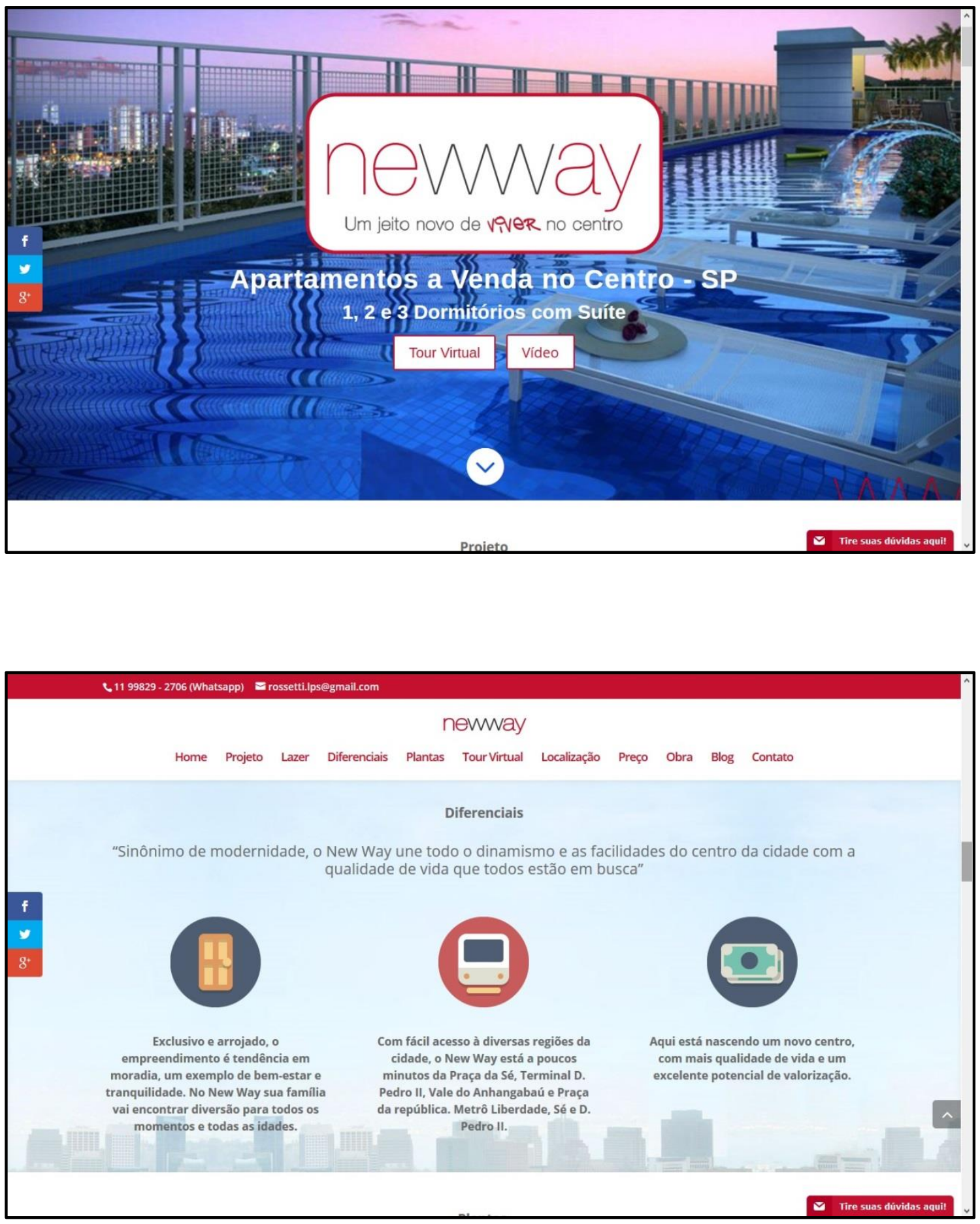


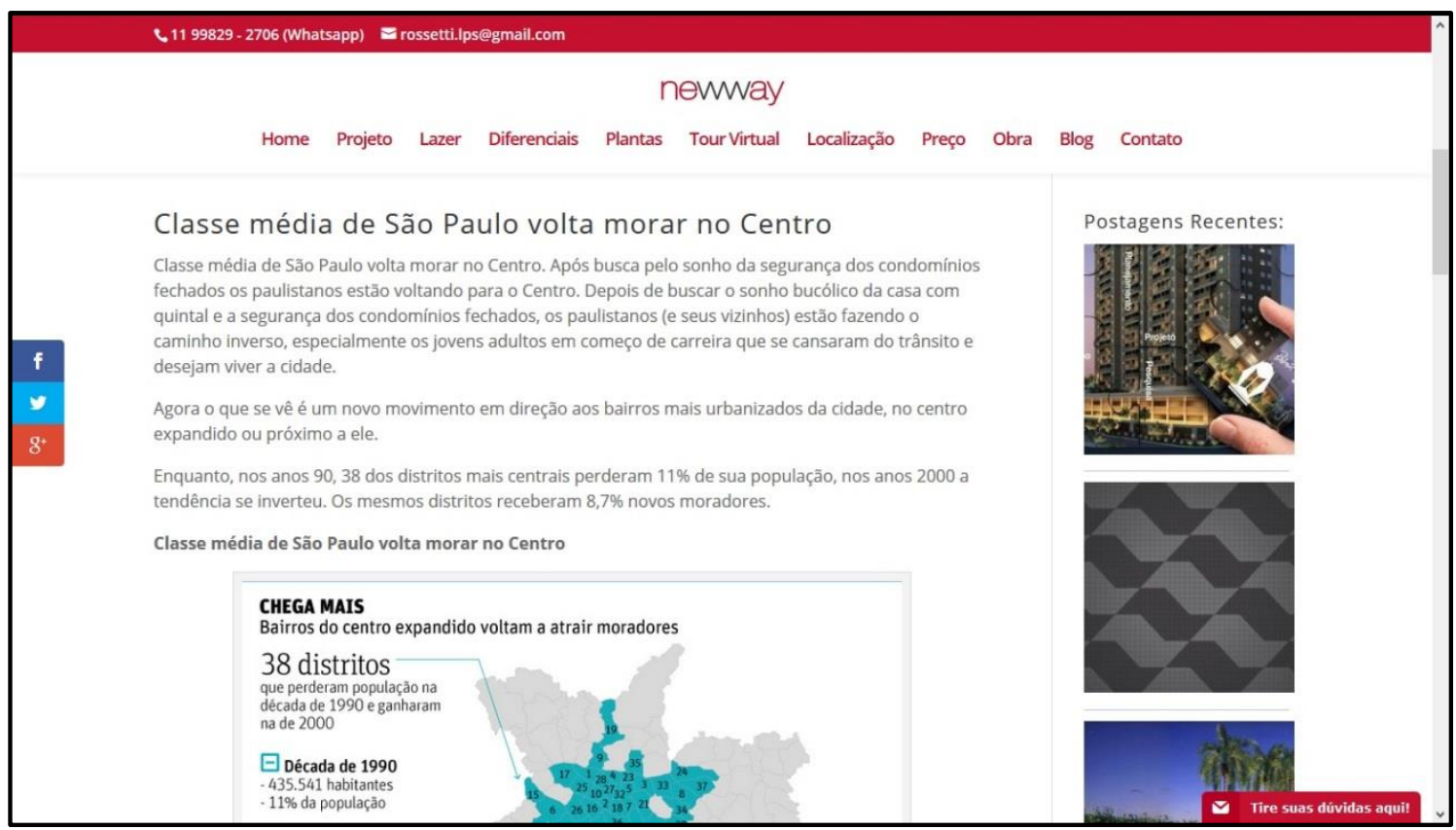

Expomos algumas chamadas para os empreendimentos que são lançados nos distritos que ficam no entorno dos distritos Sé e República. Há, como estratégia de venda, a chamada para a compra de imóveis a partir de representações do espaço ligadas à cultura, às proximidades com as estações de metrô e trem, ao próprio processo de revalorização do espaço por qual o Centro passa, entre outras. Nos distritos República e Santa Cecília, as unidades vendidas correspondem mais aquelas em formato de studios e o público alvo é o mais jovem. Nestes empreendimentos, o discurso da cultura é mais latente, acompanhado de práticas que vem ganhando mais destaque em São Paulo, como andar de bicicleta, por exemplo. O fato de não ser exigido garagem para estes novos empreendimentos, os colocam na linha de novos segmentos habitacionais direcionados ao público mais jovens, principalmente atrelados às imagens de ciclistas e praticantes de esportes.

O objetivo destes anexos é apenas oferecer ao leitor a possibilidade de visualizar como que, para além dos distritos Sé e República, os empreendedores da indústria imobiliária se apropriam dos discursos e dos conteúdos que caracterizam a reprodução do Centro para estender também para estas áreas os conteúdos das novas representações do espaço no Centro de São Paulo. 